EDS. URŠKA ŠTREMFEL AND MAŠA VIDMAR

early school leaving: contemporary european perspectives 
digitalna knjižnica - digital library

uredniški odbor - editorial board igor ž. žagar jonatan vinkler janja žmavc alenka gril 



\section{early school leaving: contemporary european perspectives}

eds. Urška Štremfel in Maša Vidmar 



\section{Contents}

11 Figures and Tables

13 Abbreviations and Acronyms

Urška Štremfel and Maša Vidmar

15 Preface

17 1.0: Introduction

Urška Štremfel \& Maša Vidmar

19 1.1: Team Cooperation to Fight Early School Leaving: Training, Innovative Tools and Actions

29 2.0: Early School Leaving: EU and National Context

Urška Štremfel

31 2.1.1 ESL in the EU: Policy Overview and Development

Maša Vidmar and Tina Vršnik Perše

51 2.1.2 The ESL Situation in France

Maša Vidmar and Tina Rutar Leban

$71 \quad$ 2.1.3 The ESL Situation in Luxembourg

Maša Vidmar and Manja Veldin

$87 \quad$ 2.1.4 The ESL Situation in Spain 
Manja Veldin and Maša Vidmar

103 2.1.5 The ESL Situation in Switzerland

Urška Štremfel

117 2.1.6 ESL in the EU: Learning from Differences and Common Trends

\section{2.2 Origin and Interplay of ESL-related Factors}

Maša Vidmar and Tina Rutar Leban

135 2.2.1 The Interplay of Factors Contributing to ESL at the Levels of the Individual, the Family and Social Background Maša Vidmar and Tina Rutar Leban

155 2.2.2 The Interplay of Factors Contributing to ESL at the School Level Maša Vidmar, Tina Rutar Leban and Tina Vršnik Perše

171 2.2.3 The Interplay of Factors Contributing to ESL at the System Level Mojca Štraus

187 2.2.4 Contextualising Early School Leaving with PISA Results

\section{2.3 Selected ESL Factors: The Basis for Prevention Activities}

Tina Rutar Leban

203 2.3.1 The Relationship Between Teachers' Teaching Styles, Students' Engagement in School and ESL

Mojca Štraus

221 2.3.2 How Teacher-teacher and Teacher-student Cooperation Link with Achievement - Evidence from International Studies

Maša Vidmar, Ana Kozina and Tina Vršnik Perše

237 2.3.3 Students' Social and Civic Competencies: Predictors of ESL Ana Kozina

255 2.3.4 Mental Health as a Risk Factor for ESL:

Diagnostics, Prevention, Intervention

Tina Rutar Leban

269 2.3.5 ESL Prevention Extended to the Home Environment:

The Relationship Between (Authoritative) Parenting Style and ESL 
Tina Vršnik Perše

287 2.3.6 Learning Difficulties and ESL

Urška Štremfel

303 2.3.7 The Role of Career Guidance in ESL

Klaudija Šterman Ivančič

323 2.3.8 The Role of Physical Activity in ESL

Ana Mlekuž

337 2.3.9 Critical Media Literacy: A New Tool and Pedagogy for Tackling ESL

\section{2. 4 Understanding the Problem and Consequences of ESL}

Urška Štremfel and Klaudija Šterman Ivančič

355 2.4.1 Why is ESL a Problem for Contemporary (EU) Society?

Klaudija Šterman Ivančič

371 2.4.2 Early School Leavers in their Later (Adult) Life and Social Consequences

385 Index

389 List of Authorities 



\section{Figures and Tables}

34 Figure 1. Tackling ESL up until 2020 within the OMC framework

38 Figure 2. Following the EU benchmark for ESL in selected TITA participating countries

55 Figure 3. France: time trend of share of the population aged 18-24 with at most a lower secondary education and not in further education or training

77 Figure 4. Luxembourg: time trend of share of the population aged 18-24 with at most a lower secondary education and not in further education or training during the last four weeks preceding the survey

91 Figure 5. Spain: time trend of share of the population aged 18-24 with at most a lower secondary education and not in further education or training

92 Figure 6. NUTS statistical regions of Spain: time trend of share of the population aged 18-24 with at most a lower secondary education and not in further education or training

108 Figure 7. Switzerland: time trend of share of the population aged 18-24 with at most a lower secondary education and not in further education or training

137 Figure 8. Bronfenbrenner's model of human development

157 Figure 9. Bronfenbrenner's model of human development

173 Figure 10. Bronfenbrenner's model of human development

239 Figure 11. The predictors of ESL examined herein

258 Figure 12. Summary of the research findings - externalisation difficulties and ESL

260 Figure 13. Summary of findings - internalisation disorders and ESL 
272 Figure 14. Conceptual framework of the relationship between parenting style/practice and education related outcomes (achievement, engagement, ESL)

330 Figure 15. Physical activity's different beneficial effects on ESL

373 Figure 16. Consequences of ESL

66 Table 1. Principal measures/institutions/networks/tools of the policy against ESL

119 Table 2. Definition of policy learning.

359 Table 3. Review of studies presenting financial gains expected from the reduction of ESL 


\section{Abbreviations and Acronyms}

CEDEFOP European Centre for the Development of Vocational Training

CMS career management skills

CPE chief education advisor (conseiller principal d'éducation)

EC European Commission

ECEC early childhood education and care

EENEE European Expert Network on Economics of Education

ELGPN European Lifelong Guidance Policy Network

ESL early school leaving

ESLer(s) early school leaver(s)

ET 2010 European Commission ,Education and Training 2010 work programme

ET $2020 \quad$ European Commission ,Education and Training 2020 work programme

EU European Union

EUROSTAT Statistical Office of the European Communities

EURYDICE Education Information Network in Europe 
GPDS ESL-Prevention Group (Group de Prévention du Décrochage scholaire)

ICT information and communications technology

ILSA international large-scale assessments

ISCED International Standard Classification of Education

MEN Ministry of National Education, France (Ministère éducation nationale)

MENJE Ministry of Education, Children and Youth, Luxembourg (Ministère de l'Education nationale, de l'Enfance et de la Jeunesse)

NESSE Network of Experts on Social Aspects of Education and Training

OECD Organisation for Economic Cooperation and Development 1

OMC Open Method of Coordination 1

PISA Programme for International Student Assessment 1

SEC social and emotional competencies 1

SES Socio-economic status

TALIS Teaching and Learning International Study

TITA Project Team cooperation to fight early school leaving: Training Innovative Tools and Actions

UK United Kingdom

USA United States of America

VET vocational education and training 


\section{Preface}

\section{Urška Štremfel and Maša Vidmar}

\section{M}

ing is regarded as being one of the most pressing. In the last two decades, it has been placed high on the European Union policy agenda and various promising solutions to the problem have been identified and policy, research and practical approaches to address it developed and implemented.

This scientific monograph, as part of the three interconnected monographs: Early school leaving: Contemporary European Perspectives, Early school leaving: Cooperation Perspectives, Early school leaving: Training Perspectives, may be seen as one of them.

Three monographs have been prepared as the scientific base within the TITA project (Team cooperation to fight early school leaving: Training, Innovative Tools and Actions). Each monograph covers in detail one of the three main pillars of the TITA approach - early school leaving, team cooperation and educators training. The three-year project forms part of the programme Erasmus+, Key Action 3 in whose framework the European Commission conducts policy experiments in order to test and improve policy implementation systems, structures and processes that have a potentially significant impact on the future EU policy agenda. The monograph offers valuable scientific insights into the topic of contemporary European perspectives of early school leaving also to the wider interested research, policy and practice community in the EU and beyond. 
We would like to express our gratitude to the many people who institutionally and personally supported us in preparing this monograph: to all those who talked things over, read, wrote, offered comments and assisted in the editing, proofreading and design. Special thanks go to our children Tija, Zarja and Jan for giving us the inner strength to start and complete this project. 


\section{I.O \\ introduction}





\section{I.I \\ Team Cooperation to Fight Early School Leaving: Training, Innovative Tools and Actions \\ Urška Štremfel \& Maša Vidmar}

Early school leaving (ESL) in the European Union (EU) is recognised as an urgent and serious problem for individuals and society as a whole. It represents the waste of both individual life opportunities and social and economic potential (European Parliament, 2011). In this context, reducing ESL is essential for achieving several key objectives of the Europe 2020 strategy. Decreasing it addresses the 'smart growth' aims by improving education and training levels as well as the 'inclusive growth' aims by targeting one of the biggest risk factors in unemployment, poverty and social exclusion. The Europe 2020 strategy therefore includes the headline target to bring the share of early school leavers (ESLers) (persons aged between 18 and 24 who leave education and training with only lower secondary education or less, and who are no longer in education and training) below $10 \%$ by 2020 , from $14.4 \%$ in 2009. That EU 2020 headline target was also acknowledged as one of the five priority areas of the strategic framework for European cooperation on education and training (ET 2020).

Although considerable effort to tackle ESL at the levels of the EU and member states has already been made (not only in the ET 2020 framework, but also of its predecessor ET 2010), the 2012 Joint Report of the Council and the Commission on the implementation of ET 2020 noted that the EU is not on track to meeting the headline ESL target by 2020 . The Education Council (2011) confirmed that all of the efforts so far to address ESL have not been effective and efficient enough and that further and new 
approaches are needed. Further, the European Commission (2011) recognised that, while the factors leading to ESL vary from country to country, the causes of ineffective policies can be boiled down to three typical issues: a) the lack of a comprehensive strategy; b) the lack of evidence-based policy-making; and c) insufficient prevention and early intervention measures. On that basis, the Education Council (2011) recommended the development of a framework for coherent, comprehensive cross-sectoral strategies and evidence-based policies against ESL so as to provide a range of school-wide and systemic policies that target different factors leading to ESL.

The Education Council invited the European Commission to support member states' strategies through the exchange of experience and good practices, and to facilitate effective peer learning, networking and experimentation with innovative approaches to measures aimed at reducing ESL and improving the educational outcomes of children and students from groups at risk of ESL (Education Council, 2011). Member states are thus supported in exploiting all opportunities of the common EU cooperation in the field, taking advantage of the existing and developing new tool kits, which will enable the EU as a whole to achieve the agreed target.

Taking the above EU initiatives into consideration, the TITA (Team cooperation to fight early school leaving: Training, Innovative Tools and Actions) project contributes to accomplishing the EU headline ESL target by addressing one of the key policy messages identifying the critical conditions for successful policies countering ESL (Thematic Working Group, 2013): to promote and support multi-professional teams in schools to address ESL by building on evidence-based policies and practices.

\section{TITA's evidence-based approach to ESL}

The TITA scientific base consists of three sections (European perspectives of ESL, Cooperation perspectives of ESL, Training perspectives of ESL) presented in three interconnected monographs. It was prepared in line with the European Commission's (2007) understanding of evidence-based education. The European Commission (ibid.) believes that such education enables the member states and EU institutions to identify the most effective education policies and practices, and allows for their effective implementation. Evidence-based education provides the foundations for modernising education systems. The improved use of knowledge that occurs as education policies and practices are developed in turn improves the quality of both the content of education policy and governance in the education field. 
This means decision-making in the area of education must be strategically oriented towards improving education based on research and evidence. In the process, policy decision-makers, experts and stakeholders should join forces in the search for ways to develop new knowledge that will, based on high-quality education, contribute to the EU's economic competitiveness and social cohesion (ibid.: 12, 13).

The TITA project consortium brings together educational experts and researchers, policymakers and practitioners from European countries in a collaborative research and implementation process that enables the evidence-based approach to ESL to be fully realised. By identifying the main factors that trigger ESL and reviewing the phenomenon's characteristics at the national, regional and local level of the consortium countries, it provides an accurate understanding of the scope and reasons behind ESL; namely, the preconditions for establishing targeted and effective evidence-based policies and practices regarding ESL. ${ }^{1}$

TITA also considers the European Commission's (2011) recommendation that policy experiments be based on precise information in order to better target measures, monitor their development, while constantly adapting them and drawing policy lessons from their results. By providing indepth information on the contextual factors of ESL in the member states making up the consortium, the TITA scientific base also takes into consideration Edwards and Downes' (2013: 47) thinking that "one implication of recognising the local sensitivity of interventions is the need for practitioners to work with data in order to make evidence-informed decisions about adjusting practices". Although Dale (2010) states that establishing the relative importance of factors, and the nature of the causal links and mechanisms, is a crucial step in enabling policymakers to formulate evidence-based, and possibly targeted, pre-emptive ESL measures, the TITA scientific base focuses more on describing and conceptualising new ways of

1 For example: a) the collection of evidence allows for the analysis of the biggest reasons underlying ESL for different groups of students, schools, and local, regional and national systems; b) the combination of data on ESL and contextual data (e.g. socio-economic information) can help in targeting measures and policies at different groups of students, as well as specific local, regional and national communities; c) gathering and analysing information on the motivation and non-cognitive skills of ESLers and their employment and career perspectives can also assist in the targeting of measures and policies; d) evaluation of the effectiveness and efficiency of the existing policy measures aimed at curtailing ESL is an important basis for improving strategies and programmes for increasing pupils' chances of school success (Council, 2011). 
working with ESLers than on assessing measurable outcomes of policy experiments (Edwards \& Downes, 2013: 48).

\section{Fields of TITA (scientific) backgrounds}

The overriding goal of the TITA project is to support the implementation of innovative policy solutions at the institutional level to reduce ESL, in line with the priorities set out in Europe 2020 and ET 2020. By promoting and supporting multi-professional teams in schools, it provides scientific support, tools for actions and training to address ESL. Therefore, the project presents innovative responses to the generally identified problem of common EU cooperation in the field of education, and thereby addresses the European goals.

Promoting and supporting the development of multi-professional teams in schools at the EU level is identified as a key to successful strategies to cut ESL. To work on ESL with other professionals and to establish student-centred measures, education staff needs to understand ESL, the basic principles of multi-professional cooperation and develop or strengthen special skills. Accordingly, the TITA comprehensive scientific base provides a detailed evidence-based understanding of: a) early school leaving (as the core policy problem the TITA project addresses), presented in this monograph; b) cooperation (as a promising solution to reducing ESL), presented in the monograph ESL: Cooperation Perspectives and training (as a tool for arriving at solutions), presented in the monograph ESL: Training Perspectives.

This monograph, focused on contemporary European perspectives of ESL, is divided into four main parts. The first subsection provides an insight into the EU and national context of ESL, including its policy framework and development, as well as the specific ESL situation encountered in the TITA consortium countries. These insights help understand the current ESL situation in the countries participating in the TITA project and are useful for exploiting the TITA results at the level of the EU and other European countries. Since the reasons for ESL vary widely from country to country and also within regions, policies to reduce ESL need to be adjusted to the specific situation a local area, region or country finds itself in.

In the second subsection, special emphasis is devoted to understanding the interplay of different factors related to ESL. ESLers are a heterogeneous group and the factors for leaving education prematurely differ vastly. Theoretical assumptions (e.g. Dale, 2010) argue that ESL stems from the 
interaction of individual-based (including those related to the family, social and community background), school-based and systemic factors. All of these factors in the TITA scientific base are also scientifically elaborated and highlighted by the results of secondary analysis of international comparative studies in education (e.g. PISA - Programme for International Student Assessment).

The third subsection relies on the assumption that knowing and understanding ESL factors is crucial when developing ESL-prevention activities. The TITA scientific base elaborates on selected factors such as teaching style, teacher-teacher and teacher-student cooperation, students' social and civic competencies, mental health, home environment, learning difficulties, career guidance, physical activity and critical media literacy in terms of their role in preventing ESL.

In the fourth subsection, the problem of ESL and its (negative) consequences for the individual and modern (EU) societies is considered more deeply in order to understand why ESL must be curtailed.

\section{Methodological aspects of the TITA scientific base}

Reflecting the TITA project's underlying rationale, its scientific base is based on an interdisciplinary approach (policy analysis, theory of organisations, pedagogy, andragogy, psychology, philosophy). By considering a wide range of research evidence, it provides a holistic approach to ESL, its understanding and targeting policies. The TITA scientific base was prepared using the following sources and methods:

\section{Theory and literature review}

A thorough review of existing theoretical and empirical research on ESL, multi-professional cooperation and training in order to provide comprehensive theoretical bases and a multidisciplinary background to develop policy experiments and elaborate on its results. In that framework, scientific monographs and articles high in academic quality and based on sound evidence are the main source of the reviews.

\section{Review of primary sources (official documents)}

A review of official sources that form the policy framework for addressing ESL at the levels of both the EU and the consortium countries (France, Spain, Luxembourg, Switzerland). The chief source of the investigation 
in this framework entails EU strategies, Council recommendations and Commission communications, as well as national laws, strategies and other legislative documents.

\section{Review of existing (good) practices}

An analysis of existing (good) policies and practices and measures in order to expose 'what works' when tackling ESL in different environments and which approaches are worthwhile learning from when developing new (school, local, national) approaches to ESL. Data for the analysis are gathered by different sources (mainly the DG EAC and EACEA websites, ESL project websites, national reports etc.). While the focus of the TITA scientific base is ESL in the EU, we also refer to practices outside Europe, which strengthens the evidence base, and suggest alternative solutions.

\section{Synthesis of the quantitative information available on ESL}

Data were gathered and analysed from different points of view (longitudinal analyses, comparison between member states, different regions and local environments in the EU). Strong disparities in ESL levels might indicate specific structural problems in certain geographical areas or educational tracks and help identify national, regional and local specificities of the phenomenon. The primary sources are EU qualitative reports, country reports, inspection reports, as well as EU and OECD (Organisation for Economic Cooperation and Development) indicators.

\section{Secondary analyses of data from international comparative assessment studies}

Secondary analyses of data emerging from international comparative assessment studies are made in areas where existing studies do not provide sufficient information on ESL that is of special importance to the TITA project. These data can provide an additional strong and robust evidence base for tackling ESL at the level of the consortium countries. These data can provide an important insight into factors that cause ESL (identification and prevention) and effective school and policy practices that contribute to reducing it (intervention). In addition, such data are not only able to explain the big differences between EU member states in attaining the EU benchmark, but can also identify the factors that help cut ESL in the member states which are making the best progress in that regard. 
In order to provide a comprehensive review of the ESL phenomenon, the TITA scientific base consists of scientific review articles that are organised in the sections and subsections already described above. Each scientific review article consists of the title, a key message in which the article's main idea is highlighted, an abstract in which the substance of the article is summarised, and the core of the article which elaborates on specific TITArelated content.

Based on the wide and deep pool of knowledge contained in the TITA scientific base, the authors have summarised its main findings in Practice Briefs (Scientific Abstracts on Early School Leaving). These Briefs summarise key (policy) messages of each scientific review article and make recommendations for practice deriving from the scientific findings. The TITA consortium believes it is important for strong and robust evidence to be presented to practitioners, policymakers and other interested members of the public in an easy-to-read format to attract their attention to the topic and enhance the opportunities to translate TITA's innovative measures into ESL policies and practices at the school, local, regional, national and international (EU) levels.

\section{Possible uses of the TITA scientific base}

The TITA consortium contends that ESL policies and practices should be evidence-based and adaptable to local, regional and national conditions. Developing such policies requires a strong political commitment but also solid knowledge of ESL processes among the wide range of actors involved. The TITA scientific base has therefore been prepared as:

- Scientific input for the TITA consortium when preparing and implementing evidence-based and targeted policy experiments for addressing ESL by promoting and supporting multi-professional teams in schools and for successfully conducting other project tasks.

- Scientific input for practitioners, implementing policy experiments in three consortium countries (France, Luxemburg, Switzerland). To work on ESL with other professionals and establish student-centred measures, education staff need to understand ESL and develop or strengthen special related skills. The scientific and comprehensive database on ESL, as summarised in 
the Briefs for Practitioners, has been prepared in order to support these ends.

- Scientific input for policymakers at the national and EU levels (European Commission) to understand the policy relevance of the project results. From the policy point of view, the TITA scientific base establishes the foundations for the effectiveness, efficiency and conditions for the scalability of the policy experimentation results and enables the transnational transfer of good practices. Ultimately, the TITA consortium believes that use of proposed and tested measures has the potential to act as a major catalyst for integrating effective and efficient ESL measures into education systems across the EU.

- Scientific review of ESL for other interested actors. The comprehensive TITA scientific base is freely available to other interested actors so they can exploit it in support of their particular requirements and interests. Although an enormous amount of research has already been done on ESL, NESSE (2010) identified the need for a more comprehensive review of what is known about ESL. The TITA scientific base is an attempt to respond to that need.

Scientific review articles, published as chapters of this monograph, are published also at the website of the TITA project (http:// titaproject.eu). Design of the website enables searching and reading the articles interactively.

\section{References}

Council of the European Union (2011). Council Recommendation on policies to reduce early school leaving. Brussels: Council of the European Union.

Dale, Roger (2010). Early school leaving. Lessons from research for policy makers. An independent expert report submitted to the European Commission. Brussels: Network of Experts on Social Aspects of Education and Training.

Edwards, Anne and Downes, Paul (2013). Alliances for Inclusion: Crosssector policy synergies and interprofessional collaboration in and around schools. An independent report authored for the European Commission. Brussels: Network of Experts on Social Aspects of Education and Training. 
European Commission (2007). Commission staff working document. Towards more knowledge-based policy and practice in education and training. Brussels: European Commission.

European Commission (2011). Communication from the Commission to the European Parliament, the Council, the European Economic and Social Committee and the Committee of the Regions: Tackling early school leaving: A key contribution to the Europe 2020 Agenda. Brussels: European Commission.

European Parliament (2011). Study on reducing early school leaving in the EU. Brussels: European Parliament.

Thematic Working Group on Early School Leaving (2013). Reducing early school leaving: Key messages and policy support. Brussels: European Commission. 

2.0

early school leaving 2.I eu and national context 



\section{I.I}

\section{ESL in the EU: \\ Policy Overview and Development}

Urška Štremfel

\section{Synopsis}

In the OMC process the EU's strategic goals on ESL are framed, measured by specific indicators and benchmarks (by 2020 the share of ESLers should be less than 10\%), translated into national ESL policies and periodically monitored. Knowing and understanding this process among all relevant actors is crucial for their more proactive involvement in ESL policy-making and contributing to good governance in the EU.

\section{Summary}

The European educational space has widened and deepened in the last two decades, which can also be recognised in the field of ESL (e.g. Walkenhorst, 2008). Since 2000, when the Open Method of Coordination (OMC) was formally established as the framework for EU cooperation in the field of education, member states have been working intensively together in order to attain their common goal/benchmark "to reduce ESL to less than $10 \%$ by 2020 ". The article systematically presents the normative framework of the EU cooperation in the ESL field in the last 20 years according to the OMC elements defined in Presidency Conclusions (2000) and illustrates how these elements have been put to good use in TITA EU member states (France, Luxemburg, Spain and Slovenia). The 
review presents examples of various general directions (e.g. Council Recommendations) as well as concrete policy and practical recommendations (e.g. Toolkits) for how to tackle ESL at the individual, school, local, regional, national and EU levels. The way EU member states transpose these EU guidelines into national policies (e.g. by setting national targets and publishing national strategies) is described along with the OMC policy learning framework (e.g. thematic working groups and policy learning activities) within which member states search for solutions to a commonly identified problem and share their related (good) practices. Finally, the role of regular (quantitative and qualitative) reporting in stimulating member states to achieve the commonly agreed goal is emphasised. The article concludes that for OMC to be an open, participative, accountable, effective and coherent process, contributing to good governance in the EU, all relevant actors in its process at all levels of the EU need to be more involved. Referring to different research findings (e.g. Lajh \& Štremfel, 2011; Ecorys, 2014) this could also be ensured by better awareness of the potential of OMC, as presented in this article.

Key words: EU, member states, ET 2020, benchmark, good governance, open method of coordination

\section{Introduction}

European cooperation in the field of education dates back over six decades, but the EU competencies in this field have remained limited until more recently (Walkenhorst, 2008). The legal basis for this is presented in the Maastricht Treaty (1992), specifying that: "The Union shall contribute to the development of quality education by encouraging cooperation between member states and, if necessary, by supporting and supplementing their action, while fully respecting the responsibility of the member states for the content of teaching and the organisation of education systems and their cultural and linguistic diversity ...".

In that framework, the open method of coordination (OMC) was introduced as a (non-obligatory) method of EU cooperation in the field of education. The Lisbon Strategy (European Council, 200o) stated that it contains the following elements: a) fixing guidelines; b) establishing quantitative and qualitative indicators and benchmarks; c) translating these European guidelines into national and regional policies; and d) periodic 
monitoring, evaluation and peer review organised as mutual learning processes (see Figure 1).

In addition to the main OMC elements, the Strategy stated that "A fully decentralised approach will be applied in line with the principle of subsidiarity in which the Union, member states, the regional and local levels, as well as the social partners and civil society, will be actively involved, using variable forms of partnership" (European Council, 2000). The White Paper on Governance (European Commission, 2001) recognised that these OMC characteristics hold great potential for respecting the principles of openness, participation, accountability, effectiveness, coherence and therefore contributing to good governance in the EU.

Soon after the formal introduction of the OMC, early school leaving (ESL) was identified as one of five concrete strategic objectives of common EU cooperation in the education field (European Commission, 2002) and even today it still represents a priority area of EU cooperation in education and one of the five targets of the overall EU 2020 Strategy. In the meantime, a comprehensive framework for cooperation on the basis of the OMC has been developing, assisting member states in their search for solutions to this pressing problem of EU society.

The main aim of the article is to provide a review of the normative policy framework for common EU cooperation in the ESL field since 2000 onwards. The review is provided in line with the four elements of the OMC as defined in the Lisbon conclusions. Each OMC element is introduced in terms of: a) basic theoretical dispositions and scientific insights into its normative functions; b) concrete examples/definitions from policy documents on ESL accepted at the EU level; and c) practical insights into its implementation at the EU level and at the level of selected TITA participating states (France, Luxembourg, Spain and Slovenia). ${ }^{\mathrm{I}}$ As such, the article does not provide a review of in-depth theoretical conceptualisations of the OMC (e.g. Alexiadou, Fink-Hafner, \& Lange, 2010; Borrás \& Radaelli, 2010) or its analytical critics and problematisation (e.g. Hatzopoulos, 2007; Büchs, 2008). It aims to raise basic awareness and understanding of the normative

1 Since Switzerland is not formally an EU member state, its involvement in the OMC processes is quite limited. According to different agreements, Switzerland is involved in various comparative studies and is an eligible country to receive financial support from various EU financial initiatives contributing to the development of educational policies and practices at the national level. Due to its constrained role in the OMC processes, practical insights into the reception of EU agendas in Switzerland in this article are very limited. 
policy framework in which policies against ESL are developed, implemented and evaluated in the EU.

EU 2020: smart, sustainable, inclusive growth

ET 2020: quality and efficiency; equity, social cohesion and active citizenship; lifelong learning and mobility; creativity and innovation Council Conclusions: comprehensive, cross-sectoral, evidence-based, prevention, intervention, compensation ESL polices

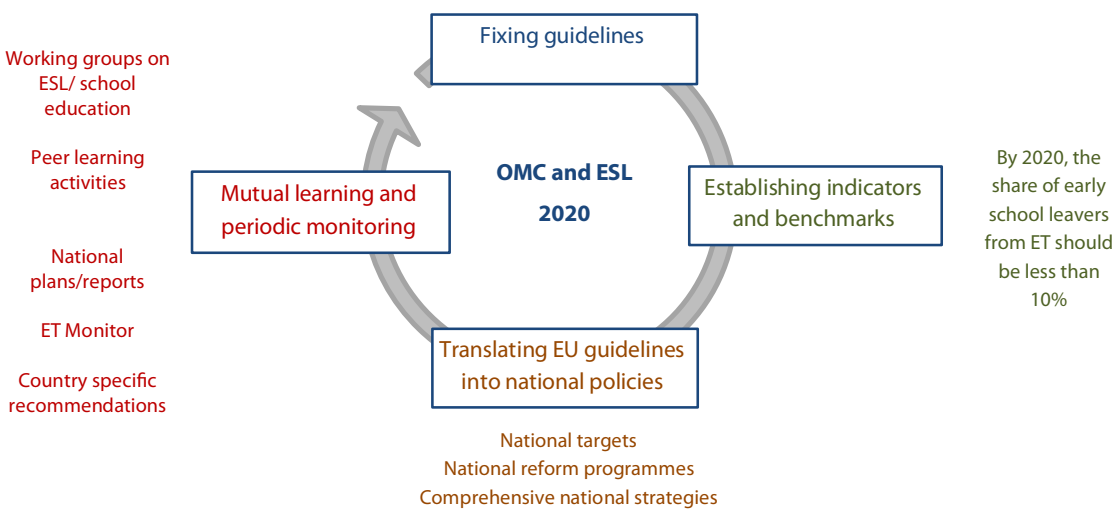

Figure I. Tackling ESL up until 2020 within the OMC framework.

\section{Methodology}

This article primarily originates from policy studies, which are recognised as important meso-level theories for explaining Europeanisation and the influence of soft law on member states. The article is qualitatively oriented and draws on a review of theoretical and empirical evidence. To address the article's aims, we employ the following methods: (a) an analysis of relevant literature and secondary sources. Here we conducted a literature search of the scientific EBSCOhost and Web of Science online research databases. The main key words used in searching the relevant scientific literature were: early school leaving, open method of coordination, education, EU, policy learning, benchmarking, monitoring. (b) An analysis of formal documents and legal sources at the EU and national levels (EU official documents in the field of educational policy, unofficial documents, press releases, an analysis of national policy documents (e.g. legislation, strategies, reports) in TITA participating countries (France, Luxembourg, Spain and Slovenia). Policy documents taken into account had to meet the following 
criteria: being published between 2009 and $2016^{2}$, being formed within the OMC framework.

\section{Studying EU policies on ESL through the OMC lens}

Fixing guidelines for the Union combined with specific timetables for achieving the goals /.../ in the short, medium and long term

By establishing common educational goals, EU member states have aimed to coherently respond to common challenges, whilst retaining their individual sovereignty in the field of education. Establishing common goals and measuring progress according to specific guidelines demonstrate the political will to identify the common problems facing European education. Such identification can unleash the envisioned capacity of cooperation to foster the greater convergence of ideas (Dehousse, 2002; Gornitzka, 2006).

Common goals of European education are first initiated by general political strategic directions, such as the well-known anticipation of the Lisbon Strategy (European Council, 200o): "By 2010 the EU should become the most competitive and dynamic knowledge-based economy in the world" and of the EU 2020 Strategy (European Council, 2009): "Smart, sustainable and inclusive growth". These two high-level EU strategies put education in the heart of the EU integration and recognise its great contribution to realising the EU's overall (social and economic) goals.

The EU 2020 strategy establishes two specific interrelated targets in the education field: to reduce rates of ESL below $10 \%$ and at least $40 \%$ of $30-$ to 34-year-olds having completed third-level education. In order to support the attainment of these goals, seven "flagship initiatives" have been developed within the Strategy, with two of them especially targeting education: An agenda for new skills and jobs and Youth on the Move. Both relate education to employability and at least indirectly point out the importance of cross-sectoral contributions in realising the EU's overall strategic goals.

2 Although ESL has been recognised as one of the priority areas of common EU cooperation since 2002, the article takes into account the second strategic framework of EU cooperation in the field of education (EU 2020 and ET 2020). References to their predecessors (Lisbon Strategy and ET 2010) are established only when needed to clarify some current issues. The reason for that is at least threefold: 1) EU 2020 and ET 2020 build on the achievement of the previous working period (2000-2009); 2) availability of the data from the previous working period is quite limited; and 3) the TITA project addresses the strategic priorities of the second working period (EU 2020 and ET 2020). 
In addition to education's generally recognised contribution to realising overall EU strategic development, more education-specific goals and guidelines are important for understanding common EU cooperation when it comes to tackling ESL.

On the basis of its predecessor ET 2010 (Council of the EU, 2002), in 2009 a new Working programme Education and Training 2020 (ET 2020) (Council of the EU, 2009) was accepted with the aim of supporting EU member states in further development of their education systems. It consists of four common strategic objectives: 1) Improving the quality and efficiency of education and training; 2) Promoting equity, social cohesion and active citizenship; 3) Making lifelong learning and mobility a reality; 4) Enhancing creativity and innovation, including entrepreneurship, at all levels of education and training. It defines a set of principles for achieving these objectives, as well as common working methods with priority areas for each periodic work cycle (Council of the EU, 2009). ESL is related to all four strategic objectives, most directly to the third one in terms of its elaboration that "Education and training systems should aim to ensure that all learners including those from disadvantaged backgrounds complete their education". Making ESL a priority area of EU cooperation in the period 2010-2020 gave a clear mandate to the European Commission, EU member states and all other relevant actors to closely work together. In that framework, various activities have been implemented with the result that many soft law (non-binding) documents have been accepted, providing general and more concrete directions for achieving the commonly agreed EU ESL goal.

3 The Council wanted a strategic framework that would remain flexible enough to respond to new challenges and could therefore be regularly adapted. This is the reason for ET 2020's 3-year work cycles with Joint Reports (adopted by the Council and the Commission) as a basis for establishing fresh priority areas for the ensuing cycle. An overview shows that ESL has been identified as a priority area in all three already activated cycles 2009-2011, 2012-2014 and 2015-2017. For example, in the current cycle (2015-2017) as a concrete issue in addressing one of the priority areas it is stated "Reducing ESL by supporting school-based strategies with an overall inclusive learner-centred vision of education and 'second-chance' and "Supporting initial education and continuing professional development at all levels, especially to deal with /.../ ESL /.../". Review of the National Report on the implementation of ET 2020 in which member states were asked to point out priority areas which they find necessary to focus EU cooperation in the next working cycle (2015-2017) on reveals that all TITA countries actually conducting the (formally non-obligatory) report (France, Luxembourg, Slovenia) exposed the importance of strengthening EU cooperation on ESL from different angles. 
Based on two European Commission communications (2011a; 2011b), the Council of the EU (2011) adopted Recommendations on policies to reduce ESL. The Council proposed six recommendations to EU member states, emphasising the importance of developing comprehensive, evidence-based prevention, intervention and compensation policies at all levels of education and as coordinated among different policy sectors. Following the progress made in 4 years by employing the OMC working methods, new Council conclusions (2015) on reducing ESL and promoting success in school have been accepted. The conclusions acknowledge the need for reinforced activities in pursuing the common EU goal, among them we expose the emphasis on prevention activities, committed participation and coordination between different policy areas, and the promotion of collaborative (whole-school) approaches to reducing ESL at the local level, as being the most relevant to the TITA project.

In order to make the achievement of agreed EU strategic goals measurable, indicators and benchmarks are established within the OMC framework. They are presented as the next OMC element in the section below.

\section{Establishing, where appropriate, quantitative and qualitative indicators and benchmarks against the best in the world and tailored to the needs of different member states and sectors as a means of comparing best practice}

The role of indicators (and benchmarks) in European education and training policy is twofold: to measure progress towards achieving commonly agreed goals and to highlight cases of good practice. By operationalising goals, indicators and benchmarks should lead to a greater transparency and a more comparable environment. They should not only be used to provide direction in those fields where more progress is required, but also be used as a tool for sanctioning and for increasing the consensus on common EU policies (Lange \& Alexiadou, 2007).

As a means of monitoring progress and identifying challenges, as well as contributing to evidence-based policy-making, a series of 'European benchmarks' was established to support the EU 2020 and ET 2020 strategic objectives. As mentioned, in both documents the benchmark for ESL is defined "by 2020 the share of early leavers from education and training should be less than $10 \%$ ". 


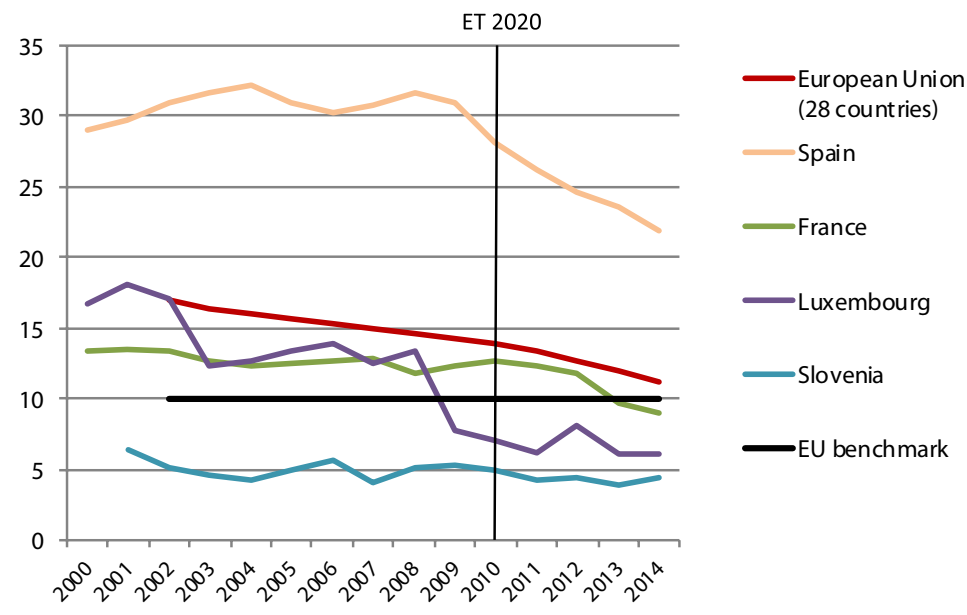

Figure 2. Following the EU benchmark for ESL in selected TITA participating countries (Eurostat, 2016)

Although presentations of benchmarks being attained are very simplified (see Figure 2), the unsettled questions about their development and appropriate interpretation are much more comprehensive.

Benchmarks are defined as reference levels for average European performance, meaning they should not be considered as concrete targets for individual member states to reach by 2020. Instead, member states (for example, both Slovenia currently with a $4.4 \%$ ESL rate and Spain currently with a $21.9 \%$ ESL rate) are invited to consider, based on their national priorities and after taking the changing economic circumstances into account, how and to what extent they can contribute to the collective achievement of the European benchmark through their national actions (Ecorys, 2014, p. 5).

It should be noted that benchmarks never show internal particularities/problems of a particular education system (e.g. in the case of ESL, different ESL rates between regions, different social groups within a country etc.) and that, when interpreting the ESL rates in a given country, other national contextual factors (e.g. welfare tradition, unemployment rate of ESLers etc.) should also be taken into consideration.

Another important issue present is the statistical infrastructure at both the EU level and the level of member states, which enables adequate measurement of a selected indicator/benchmark. As seen from the Education and Training Monitor (European Commission, 2015, p. 34), 
despite 15 years of common cooperation in the field, ensuring a comparable environment for measuring the ESL rate among all EU member states remains challenging.

Once EU member states agree on the particular indicator(s) and/or benchmark(s) they will use to measure the attainment of commonly agreed strategic goal(s), they sovereignly decide how they will translate the EU guidelines into their respective national contexts and which national policies they will develop in order to follow commonly agreed EU goals.

\section{Translating these European guidelines into national and regional policies by setting specific targets}

The OMC is particularly interesting for the way in which it directs both national and sub-national policy-making in EU matters (Alexiadou, 2007, p. 4). The OMC does not require new legislation or the transposition of EU legislation to suit European directives; further, this is not a precondition for change, reform or implementation within a respective member state (Lopez-Santana, 2006). Therefore, the EU's influence in the education field is intended to be visible not just in structural and policy changes but also in the internalisation of European values and policy paradigms at the national level and in the way political debates and identities are changing. It is argued that the OMC has an impact especially on the cognitive level of public policies, for example, on the discourse of political actors and policy concepts. It stimulates national debates and provides various interests with arguments in support of policy change, and consequently offers arguments that legitimise national reforms (e.g. modernisation of education systems) (Radaelli, 2003).

In the case of ESL, the process of translating EU agendas into national contexts is anticipated in the following way: As part of the Europe 2020 strategy, member states have agreed at the highest political level to set national targets on reducing ESL, taking their starting position and national circumstances into account. It is supposed that (ambitious) national targets (e.g. 9.5\% France, 10\% Luxembourg, 15\% Spain, 5\% Slovenia) foster policy development in this area and increase the pressure for efficient and effective national policies. Strategies and actions for pursuing targets are elaborated in National Reform Programmes. In addition, the Council of the EU (2011) invited member states to "ensure that comprehensive strategies on ESL are in place by the end of 2012, and that they are implemented in line with national priorities and the Europe 2020 objectives". Education and Training 
Monitor 2015 reveals that the majority of member states has implemented the Council Recommendation by adopting either explicit comprehensive strategies (e.g. France) or other national policies (e.g. Luxembourg and Spain) (European Commission, 2015b, p. 37).

In the OMC framework various operational documents have been accepted at the EU level, assisting member states in implementing their national policies on ESL. The working group on ESL outlined 12 key messages for policy-makers and translated them into practical tools through a checklist regarding comprehensive policies on ESL (European Commission, 2013). The working group on school policy created policy messages, identifying key conditions for implementing a whole-school approach to tackling ESL as well as an online "Toolkit for Schools", supporting (national) policy-makers and practitioners in their efforts to tackle ESL (European Commission, 2015a).

The review shows that, despite the non-obligatory nature of the OMC (no harmonisation of EU laws), in nation states various policy measures are accepted which, at least to some extent, are initiated by EU-level processes. Since the process of translating EU guidelines into national contexts is very differently and in some states weakly organised, Ecorys (2014) recommends that the European Commission and member states share their (good) practices in this regard.

For translating EU guidelines into national contexts and developing their national policies on ESL, member states have a variety of mutual policy learning activities available within the OMC framework. They enable member states to share good practices and therefore collectively search for solutions which lead to the achievement of commonly agreed goals (as measured by indicators and benchmarks).

\section{Periodic monitoring, evaluation and peer review organised as mutual learning processes}

To reflect the complexity of the last OMC element, we split its presentation into two parts. The first part presents peer review organised as a mutual learning process and the second part presents periodic monitoring and evaluation.

Various academics (e.g. Gornitzka, 2006; Radaelli, 2008; Lange \& Alexiadou, 2010) claim that the OMC represents the "architecture of policy learning". Seen in this way, the OMC is an institutional arrangement which organises policy learning process among member states. This means 
that, irrespective of their different traditions, systemic differences, and the lack of a normative interpretation of European integration, states can learn from each other and improve their policies for achieving common goals. Since all actors aspire towards the same goals, mutual learning is regarded as a rational form of collective problem-solving. The OMC thus acts as a radar by searching for solutions and new applicable knowledge through an iterative process of organising peer leaning activities and sharing best practices.

The OMC framework reveals that mutual learning takes place through peer-learning activities, conferences and seminars, high-level forums, experts groups, panels, studies and analyses, involving the relevant stakeholders. Outputs can take the form of overviews of policy measures and examples of good practices (e.g. an inventory of good practices), analytical papers, guidelines and handbooks for policy implementation (Ecorys, 2014, p. 7).

Thematic working groups as the most important form of policy learning within the framework of the OMC and ET 2020 at the EU level are established on the basis of the rich experiences of their predecessor - clusters in ET 2010. The mandates of working groups correspond to the priorities of each (3-year) working cycle. In line with defining ESL as a priority, two working groups were especially dealing with ESL in the ET 2020 framework:

A thematic working group on ESL was active from 2011 to 2013 and consisted of policy-makers, practitioners and experts from 27 EU member states and key European stakeholder organisations. It focused on developing (effective) comprehensive policies on ESL. Its activities included peer-learning visits to the Netherlands and France and a peer review event in Brussels in March 2013. The main conclusions and lessons learnt by the thematic working group are presented in its final report (European Commission, 2013). It aims to inspire and generate the development of a comprehensive approach to ESL, especially with a checklist as a tool for self-assessment with which member states can evaluate the comprehensiveness of their current ESL policies and identify areas for further improvement (European Commission, 2016).

- The working group on Schools Policy was active between 2013 and 2015, consisting of policy-makers from almost all EU member states and representatives of European social partners. It focused 
on holistic and collaborative ESL prevention and early intervention activities at the school and local levels. Based on its activities (peer learning, analysis of case studies, mapping of school governance arrangements and of practices to support learners, inputs from international research, dialogue with experts, and in-depth country-focused workshops), the working group published Policy messages on A whole school approach to ESL, as well developed the online platform "European Toolkit for Schools for inclusive education and early school leaving prevention", which provides support to schools to prevent ESL.

The review reveals that the mandates of the new thematic working groups (2016-2018) do not explicitly cover the ESL issue ${ }^{4}$, although: a) ESL is identified in priority areas and concrete issues for European cooperation in education and training until 2020 (Council ot the EU, 2015, and European Commission, 2015a); and b) the EU has still not reached its headline target (less than 10\% of ESLers by 2020) (European Commission, 2015a).

OMC policy learning activities are supposed to be implemented at different levels, by either organising activities at the EU level or stimulating member states for national policy learning, as in the case of Council conclusions (2015) which invite member states "to encourage and promote collaborative ('whole-school') approaches to reducing ESL at local level, for instance through cooperation between schools of different types and levels which are located in the same area, as well as networking and multi-professional learning communities at regional, national and international levels /.../".

In order to monitor the success of EU member states in attaining the commonly agreed goals, various progress reports are published within the OMC framework. They help recognise potential problems, identify good practices and therefore stimulate policy learning among member states concerning how to meet commonly agreed goals.

For national actors, the periodic monitoring and regular reporting in the OMC are a special task with set deadlines. These reports feed information back into the European education process regarding how measures

4 Two of the six working groups (Working group on schools; Working group on promoting citizenship and the common values of freedom, tolerance and non-discrimination through education - follow-up to the Paris Declaration) only indirectly indicate ESL as a Relevant Europe 2020 target/ET 2020 benchmark, which their work is related to. 
framed at the EU level have been taken into consideration in the member states (qualitative reports) and how they help in realising commonly defined goals (quantitative reports). National reports are then integrated into the various EU-level reports. There are differing theoretical considerations about how these progress reports by either literally exposing countries which have not implemented EU recommendations or numerically showing which countries are lagging behind in achieving the commonly agreed goals, or by naming and shaming exert pressure on member states to perform well (improve their educational policies and practices in line with the commonly agreed direction) (Gornitzka, 2006; Radaelli, 2008; Lange \& Alexiadou, 2010).

Member states are supposed to report on their ESL policies and their results in both the EU 2020 and ET 2020 frameworks. In the EU 2020 setting, they prepare annual reports on their annual National Reform Programmes. The European Commission and the Council prepare country-specific recommendations based on their analyses. While these Recommendations are not legally binding, their influence relies on their political weight (Ecorys, 2014, p. 11). Although they are mostly focused on the broader macro-economic situation in member states, in some cases they provide concrete recommendations for an education/ESL field. For example, the Council of the EU recommends that France "take further actions to reduce educational inequalities in particular by strengthening measures on ESL" (Council, 2014a) and recalled in relation to Spain that "Some progress has been registered in measures to fight ESL /.../, but full implementation and efficient use of funding remain crucial".

In the ET 2020 framework, two kinds of progress reports are prepared.' The Annual Education and Training Monitor (e.g. European Commission, 2015b), based on data from Eurostat, the OECD and other statistical organisations provides an insight into the evolution of all and particular member states with respect to the ET 2020 benchmarks and indicators (annual qualitative reports). Biannually, the member states also prepare qualitative reports on their progress on the basis of a prepared template. These reports are analysed and summarised by the European Commission and the Council, assessing the EU's overall progress towards realising goals, and exposing the group of countries performing well/poorly or having good

5 Another kind of reports, providing cross-national comparisons and important expert input to the OMC process, are various reports of expert bodies or networks (such as NESSE, 2010; European Parliament, 2011; EENEE, 2013; Eurydice, 2014). 
practices in attaining particular goals. For example, in 2015 they exposed that Europe was not on track to achieve the headline target, there is an urgent need to strengthen the (coherent) policy approach. It points out that there should be a stronger focus on preventive and early intervention measures in the contexts of teacher education, continuing professional development and quality early childhood education and care, and that only a few countries (including France and Luxembourg) take a systematic approach to collecting, monitoring and analysing data on ESL.

When EU member states realise in their progress reports how successful/unsuccessful they have been in a certain working cycle/period towards attaining a particular indicator and benchmark and the long-term strategic goal, the OMC process is not finished. On the contrary, it is iterative process (see Figure 1) that, by once again using all the OMC elements, enables member states to face the same or new educational/ESL challenges in a new working cycle/period.

\section{Conclusions - towards the OMC as good governance}

The OMC framework (its elements and process) at least normatively contribute to the achievement of the common EU strategic goals and in ensuring good governance in the EU. Realising the OMC as good governance requires that various actors are actively involved in policy learning processes at different levels of the EU. Research results (Lajh \& Štremfel, 2011; Ecorys, 2014) show that the OMC process and its potential are currently not well known among (national) actors, what may be seen as an important obstacle to their more proactive role in the OMC process.

From that perspective, it is crucial that all actors important for tackling ESL in the EU (not only policy-makers and experts, but also non-governmental organisations, social partners and practitioners) know and understand the OMC process through which EU strategic goals are framed (e.g. smart, sustainable and inclusive growth), measured by specific indicators and benchmarks (by 2020 the share of ESLers from education and training should be less than 10\%), translated into national policies (e.g. by setting specific national targets and adopting national ESL strategies) and periodically monitored (by regular qualitative and quantitative reporting and mutual learning processes) (see Figure 1).

In the article, this normative OMC framework is presented and illustrated with examples of specific results which can be used by many actors dealing with ESL at the EU, national, regional, local and school levels. 
Their better awareness of all the potential of the OMC could trigger their more active involvement in the OMC process, either via their active participation in the various OMC activities that were presented or by simply considering different guidelines (e.g. Policy recommendations, Toolkit for practitioners) already produced in the OMC framework in order to support policy-makers and practitioners in their efforts to tackle ESL alone or by engaging in various forms of partnership. Their acquaintance can therefore represent a step forward not only towards a more open, participative, accountable, effective and coherent OMC process but also towards more open, participative, accountable, effective and coherent EU and national policies against ESL through which they are framed.

\section{References}

Alexiadou, N. (2007). The Europeanisation of education policy - changing governance and "new modes of coordination". Research in Comparative and International Education, 2(2), 102-116.

Alexiadou, N., \& Lange, B. (2013). Deflecting European Union influence on national education policy-making: The case of the United Kingdom. Journal of European Integration, 35(1), 37-52.

Alexiadou, N., Fink Hafner, D., \& Lange, B. (2010). Education policy convergence through the Open Method of Co-ordination (OMC): Theoretical reflections and implementation in "old" and "new European Educational Research Journal, 9(3), 345-358.

Borrás, S. \& Radaelli, C. M. (2010). Recalibrating the Open Method of Coordination: Towards diverse and more effective usages. Stockholm: Swedish Institute for European Policy Studies, SIEPS Working Paper, No. 2010: 7 .

Büchs, M. (2008). How legitimate is the Open Method of Co-ordination? Journal of Common Market Studies 46(4): 765-786.

Dehousse, R. (2002, September). The Open Method of Coordination: A new policy paradigm? Paper presented at the First Pan-European Conference on European Union Politics »The Politics of European Integration: Academic Acquis and Future Challenges «, Bordeaux, France.

Council of the EU. (2001). Report from the Education Council to the European Council "The concrete future objectives of education and training systems«. Retrieved from http://ec.europa.eu/education/policies/2010/doc/ rep_fut_obj_en.pdf 
Council of the EU. (2002). Working programme Education and Training 2010. Retrieved from http://eur-lex.europa.eu/LexUriServ/LexUriServ. do?uri=OJ:C:2002:142:0001:0022:EN:PDF

Council of the EU. (2009). Council conclusions of 12 May 2009 on a strategic framework for European cooperation in education and training ("ET 2020”). Retrieved from http://eur-lex.europa.eu/legal-content/EN/TXT/ $\mathrm{PDF} /$ ?uri=CELEX:52009XG0528(01)\&from $=\mathrm{EN}$

Council of the EU. (2011). Council Recommendation on policies to reduce early school leaving. Retrieved from http://eur-lex.europa.eu/legal-content/ EN/TXT/PDF/?uri=CELEX:32011Ho701(01)\&from=EN

Council of the EU. (2015). Council conclusions on reducing early school leaving and promoting success in school. Retrieved from http://eur-lex.europa. eu/legal-content/EN/TXT/PDF/?uri=CELEX:52015XG1215(03)\&from=EN.

Council of the EU and European Commission. (2012). 2012 Joint Report of the Council and the Commission on the implementation of the Strategic Framework for European cooperation in education and training (ET 2020) "Education and Training in a smart, sustainable and inclusive Europe". Retrieved from http://eur-lex.europa.eu/legal-content/EN/TXT/ $\mathrm{PDF} /$ ?uri=CELEX:52012XGo308(o1)\&from=EN

Ecorys. (2014). Interim evaluation of the strategic framework for European cooperation in education and training (ET 2020). Retrieved from http:// ec.europa.eu/dgs/education_culture/more_info/evaluations/docs/ education/et2020_en.pdf

EENEE (European Expert Network on Economics of Education). (2013). The costs of early school leaving in Europe. Retrieved from http://www.eenee. de/eeneeHome/EENEE/Analytical-Reports.html

European Council. (2000). Lisbon European Council 23-24 March 2000. Presidency Conclusions. Retrieved from http://www.europarl.europa.eu/ summits/lisı_en.htm

European Commission. (2001). European governance. A white paper. Retrieved from http://eur-lex.europa.eu/LexUriServ/site/en/com/20o1/ com2001_0428eno1.pdf

European Commission. (2002). Communication from the Commission: European benchmarks in education and training: follow-up to the Lisbon European Council. Retrieved from http://eur-lex.europa.eu/LexUriServ/ LexUriServ.do?uri=COM:2002:0629:FIN:EN:PDF

European Commission. (2010). Communication from the Commission: Europe 2020 A strategy for smart, sustainable and inclusive growth. Retrieved 
from http://ec.europa.eu/eu2o2o/pdf/COMPLET\%2oEN\%2oBARROSO\%20 \%20\%20007\%20-\%20Europe\%202020\%20-\%20EN\%2oversion.pdf

European Commission. (2011a). Reducing early school leaving, Commission Staff Working Paper.

European Commission. (2011b). Communication from the Commission to the European Parliament, the Council, the European Economic and Social Committee and the Committee of the Regions Tackling early school leaving: A key contribution to the Europe 2020 agenda.

European Commission. (2012). Communication from the Commission to the European Parliament, the Council, the European Economic and Social Committee and the Committee of the Regions Rethinking Education: Investing in skills for better socio-economic outcomes. Retrieved from http://eur-lex.europa.eu/legal-content/EN/TXT/ $\mathrm{PDF} /$ ?uri=CELEX:52012DC0669\&from $=\mathrm{EN}$

European Commission. (2013). Reducing early school leaving: Key messages and policy support. Final Report of the Thematic Working Group on Early School Leaving. Retrieved from http://ec.europa.eu/education/policy/ strategic-framework/doc/esl-group-report_en.pdf

European Commission. (2015a). Education \& Training 2020. Schools policy A whole school approach to tackling early school leaving Policy messages. Retrieved from http://ec.europa.eu/education/policy/strategic-framework/ expert-groups/documents/early-leaving-policy_en.pdf

European Commission. (2015b). Education and Training Monitor. Retrieved from https://ec.europa.eu/education/library/publications/monitor15_en.pdf European Commission. (2016). Early school leaving. Retrieved from http:// ec.europa.eu/education/policy/school/early-school-leavers_en.htm

European Commission/EACEA/Eurydice (2013). Education and Training in Europe 2020: Responses from the EU Member States. Eurydice Report. Brussels: Eurydice.

EC/EACEA/Eurydice/Cedefop. (2014). Tackling Early Leaving from Education and Training in Europe: Strategies, Policies, and Measures. Eurydice and Cedefop Report. Luxembourg: Publications Office of the European Union.

European Parliament. (2011). Reducing early school leaving in the EU. Study. Retrieved from http://www.europarl.europa.eu/RegData/etudes/etudes/ join/2011/460048/IPOL-CULT_ET(2011)460048(SUMo1)_EN.pdf 
Eurostat. (2016). Early leavers from education and training. Retrieved from http://ec.europa.eu/eurostat/statistics-explained/index.php/ Early_leavers_from_education_and_training

Gornitzka, A. (2006). The Open Method of Coordination as practice - A watershed in European education policy? Oslo: University of Oslo, Arena Working Paper, No. 16/2006.

Hatzopoulos, V. (2007). Why the Open Method of Coordination is Bad for You: A Letter to the EU. European Law Journal 13(3), 309-342.

Lajh, D., \& Štremfel, U. (2011). Exploiting the potential of the Open Method of Coordination in Slovenian education policy. Czech Sociological Review, 47(3), 507-529.

Lange, B., \& Nafsika A. (2007). New forms of European Union governance in the education sector? A preliminary analysis of the Open Method of Coordination. European Educational Research Journal, 6(4), 321-335.

Lange, B., \& Nafsika A. (2010). Policy learning and governance of education policy in the EU. Journal of Education Policy 25(4), 443-463.

Lascoumes, P., \& Le Galès, P. (2007). Introduction: Understanding public policy through its instruments - From the nature of instruments to the sociology of public policy instrumentation. Governance, 2o(1), 1-21.

López-Santana, M. (2006). The domestic implications of European soft law: Framing and transmitting change in employment policy. Journal of European Public Policy, 13(4), 481-499.

MEN (Ministère éducation nationale). (2014a). Évaluation partenariale de la politique de lutte contre le décrochage scolaire. Rapport de diagnostic, Mars 2014. Retrieved from http://cache.media.education.gouv.fr/file/2014/85/8/ Rapport-Evaluation-partenariale-de-lutte-contre-le-decrochagescolaire_331858.pdf

MEN. (2014b). Évaluation partenariale de la politique de lutte contre le décrochage scolaire. Rapport final, November 2014. Retrieved from http://cache. media.education.gouv.fr/file/2014/24/2/MAP_Decrochage_Rapport_final_369242.pdf

MEN. (2014c) Réponse des autorités françaises sur la mise en oeuvre du cadre stratégique pour la coopération européenne dans le domaine de l'éducation et de la formation "ET 2020". Retrieved from http://ec.europa.eu/education/ policy/strategic-framework/doc/et2020-national-report-fr_fr.pdf

Ministère de'l Education nationale, de l'Enfance et de la Jeunesse. (2014). ET 2020 National Report 2014 Luxembourg. Retrieved from http:/ec.europa.eu/ education/policy/strategic-framework/doc/et2020-national-report-lu_fr.pdf 
Ministry of Education, Science and Sport. (2014). ET 2020 National Report Questionnaire. Retrieved from http://ec.europa.eu/education/policy/ strategic-framework/doc/et2020-national-report-sl_en.pdf

NESSE (Network of Experts in Social Sciences of Education and Training). (2010). Early school leaving: lessons from research for policy makers. An independent expert report submitted to the European Commission. Retrieved from http://www.nesse.fr/nesse/activities/reports/activities/ reports/early-school-leaving-report

Radaelli, M. C. (2003). The Open Method of Coordination: A new governance architecture for the European Union? Stockholm: Swedish Institute for European Policy Studies, SIEPS Working Paper, No. 2003:1.

Radaelli, M. C. (2008). Europeanization, policy learning, and new modes of governance. Journal of Comparative Policy Analysis, 10(3), 239-254.

Walkernhorst, H. (2008). Explaining change in EU education policy. Journal of European Public Policy, 15(4), 567-587. 



\section{I.2}

\section{The ESL Situation in France}

Maša Vidmar and Tina Vršnik Perše

\section{Synopsis}

The ESL rate in France has been below the Europe 2020 target of $10 \%$ since 2013 , yet regional and subgroup differences remain. Since November 2014 France has had a comprehensive strategy to tackle ESL that provides for the establishment of multi-professional ESLprevention groups in all secondary schools. The involvement of teachers in these groups is underway.

\section{Summary}

According to the latest Eurostat data, the early school leaving (ESL) rate in France was 9.3\% in 2015, namely below both the Europe 2020 target of $10 \%$ and the national target of $9.5 \%$. The trends show a steady decline over the years. However, large discrepancies between regions and subgroups remain (the ESL rate is higher for males than females and for foreign-born compared to native-born). Beside Eurostat's definition of ESLer, France also collects data in accordance with its national definition. The issue of ESL has received much political attention in the last decade. In recent years, numerous measures have been put in place, but lacking national/systemic coordination. An attempt to overcome this resulted in the national strategy to tackle ESL (Tous mobilisés contre le décrochage - Together against early school leaving) approved in November 2014 that put a greater focus on prevention (traditionally compensation measures have been 
stronger) and called for the collaboration of all actors (inside and outside of school). The strategy allowed/aimed for proliferation of multi-professional ESL-prevention groups (group de prévention du décrochage scholaire - GPDS) in all secondary schools. This group brings together the head of an institution, school management, the teaching staff, the conseiller principal d'éducation (CPE), the guidance counsellor along with social and health workers. It aims to find adequate support for the young. ESL-prevention groups across different schools vary greatly in their practices and modes of organisation; particularly in the level of teacher involvement and external actors (outside of school). ESL-prevention groups are closely linked to the establishment of educational alliances; in fact, such groups may be seen as an internal educational alliance. It seems that in the following years the challenge regarding multi-professional collaboration will be to put into practice what has been envisioned in the national strategy and supporting documents.

Key words: France, policy measures, ESL statistics, multi-professional ESL-prevention groups, ESL officer

\section{Introduction}

Embedded in the European context of the Europe 2020 strategy reducing is one of the major issues of French society and, as such, a national priority (MEN, 2014a). The volume of different policy and operational documents on the topic of ESL in France is impressive, indicating this topic has indeed received significant political, professional and public attention in recent years. The process is ongoing, resulting in new policy and/or operational documents being published regularly (e.g. the ESL action plan for 2015/ 16, MEN, 2015a).

The aim of this article is to give an overview of the complex state of affairs as well as recent trends regarding ESL in France. In the introduction, some characteristics of the French education system relevant to ESL are presented (i.e. transitions, length of compulsory education, grade retention; for a literature review about relevant system characteristics, also see EC/EACEA/Eurydice/Cedefop, 2014; NESSE, 2010; PPMI, 2014), including some relevant recent reforms. This is followed by statistics on ESL and an insight into the French ESL situation with a focus on multi-professional collaboration related to ESL. The purpose of the article is to elucidate the 
context in which experiments within the TITA project are taking place, thus guiding the interpretation and generalisations of the findings.

\section{Methodology}

The article draws information from European documents (European Commission - EC, Eurydice), Eurostat, ministerial documents on ESL and other documents and reports available online (prepared by French local governments or institutions). A search for scientific articles was conducted using the key words 'early school leaving', 'drop-out' and 'France' in the ASU Libraries search engine, resulting in very few hits (only one was relevant to this article). This supports Berthet and Simon's (2012) claim that up until very recently only a few academic works had examined this topic in France (academic articles in English are even rarer; for an exception, see the review by Thibert, 2013). A search was also conducted using the backward procedure.

\section{Some relevant characteristics of the French education system}

Education in France is compulsory between the ages of 6 and 16 (Eurydice, 2014). This period is marked by two transitions: from primary school (école élémentaire, ages 6-11 years) to lower secondary education (collège, ages 1115 years) and then to upper secondary education (lycée, ages 15-18 years). Streaming begins after the end of collège with the transition to lycée at age 15; the first year of lycée is part of the compulsory education. Lycée can be general/technical, professional or can serve as an apprenticeship. Grade retention is possible, but under a new law (Guidance and Programming Law, 2013-595) this became an 'exceptional' practice (Eurydice, n.d.). Moreover, early childhood education (ECEC) is strong in France; children over 3 years are legally entitled to a free place in écolle maternelle; over $99 \%$ of children attend (EC/EACEA/Eurydice/Eurostat, 2014). Schools are obliged to provide education and career guidance services; these are provided by school staff and guidance counsellors outsourced from the Information and Orientation Centres (EC/EACEA/Eurydice/Cedefop, 2014).

Another special feature of the French education system is the educational non-teaching educational staff conseiller principal d'éducation (CPE - chief education advisor). The CPE is senior staff responsible for ensuring that school life runs smoothly and supports pupils' learning (Eurydice, n.d.). These responsibilities mainly cover running of the school (organisation of 
day-to-day life within school), collaboration with teaching staff, and educational facilitation (ibid.).

Several reforms in school and vocational education and training (VET) have taken place in France since 2013 that hold implications for preventing ESL, but do not directly address it: e.g. reforms of ECEC, school timetable, initial and continuous teacher education, priority education (related to schools in disadvantaged areas), assessment (see Eurydice, n.d. for details). On the other hand, some reforms have been directly related to ESL (see below for details).

In relation to governance, the French education system is by tradition centralised, although the process of decentralisation over the last three decades has led to the increasingly significant role of local authorities (i.e. 26 regions, about 100 departments and over 36,000 municipalities). In partnership with académie (i.e. administrative district in national education systems, generally corresponding with regions), they implement state policy as the most appropriate to local context (Eurydice, n.d.). This implies that also in relation to tackling ESL local authorities and academies are in charge of the local implementation and adaptation of central-level measures, leading to tensions between governance levels (Berthet \& Simon, 2012).

\section{ESL statistics in France}

Two national definitions of ESL are in use alongside the Eurostat one: 'non-graduate leaver' (students who leave education without having obtained an upper secondary qualification) and 'drop-out' (students who leave education before completing a programme they are attending below upper secondary education) (EC/EACEA/Eurydice/Cedefop, 2014). In addition to collecting data for Eurostat, France also collects data in accordance with the national definition. There has been some debate as to whether the ministry collects data on ESL in an unbiased way (for details, see Thibert, 2013).

Figure 3 shows Eurostat's ESL rate in France in the last two decades. A steady decline can be observed, even though comparability over time before 2005 (at EU level) and even after 2013 (France-specific methodological changes, EC, 2014b) is limited. The ESL rate in France has traditionally been below the EU average.

The ESL rate in France dropped below the Europe 2020 target of $10 \%$ for the first time in 2013 and below the national target of 9.5\% in 2014. In 
2015, the ESL rate was 9.3\% (Eurostat, 2016b). Despite the relatively low overall rate of ESL, there are large discrepancies linked to socio-economic and cultural factors and between regions (i.e. from 5.8\% in Midi-Pyrénées to $14.8 \%$ in Picardie in 2014; Eurostat, n.d.). The share of early leavers was higher for foreign-born versus native-born (17.8\% versus 9.1\%) and for males versus females (10.7\% versus $8.7 \%$ ) in 2014 (EC, 2014a). The same was true in 2015 (14\% and $8.1 \%$ for foreign-born and native-born; $9.5 \%$ and $7.4 \%$ for males and females, respectively; EC, 2015). This is relevant to tackling inequality in France.

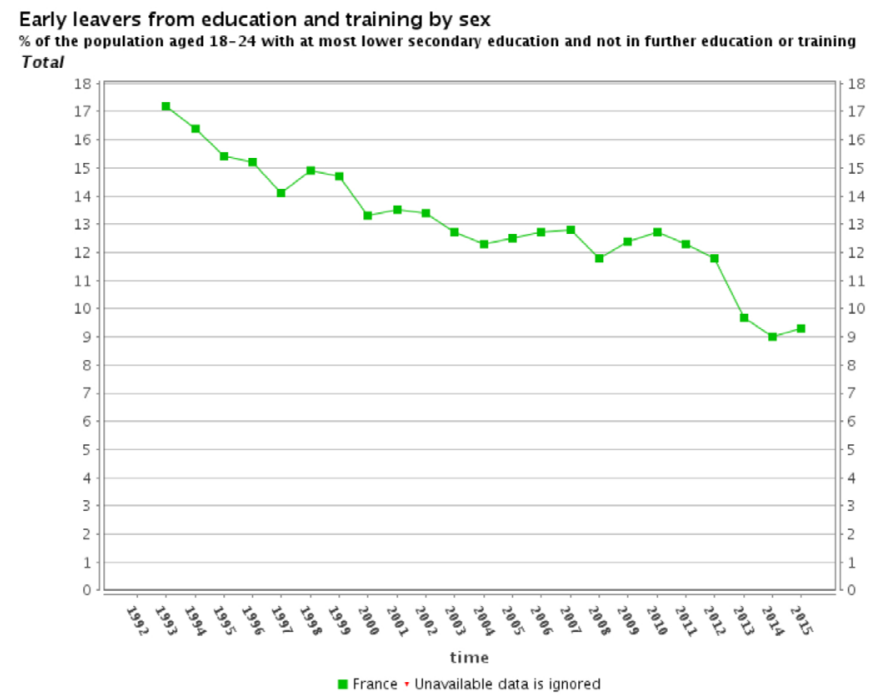

Figure 3. France: time trend of share of the population aged 18-24 with at most a lower secondary education and not in further education or training (Eurostat, 2016a)

Note. Lower secondary education refers to ISCED (International Standard Classification of Education) $201 \mathrm{r}$ level o-2 for data from 2014 onwards and to ISCED 1997 level o-3C short for data up to 2013. In 2012, France changed methodology.

\section{Insight into tackling the ESL issue in France}

Up until the early 2000 s ESL was not high on the political agenda in France, but this has changed in the last decade. ESL has become a public problem and was even directly addressed in the presidential campaign in 2012 (Berthet \& Simon, 2012; MEN, 2014a, b). It is important to note that some French academics have challenged this view, more specifically they have 
highlighted the steadily decreasing number of ESLers (also see Figure 3) and at the same time there is ever more talk about ESL as a problem; moreover, they have challenged the idea that increasing people's qualifications will solve the problem (e.g. Bernard, 2013; Bernard \& Venart, 2013; Berthet, 2013; Berthet \& Simon, 2012; Dubet, 2015; Huart, 2013).

As a result of the attention to the issue of ESL, many measures/actions/ bodies/institutions/networks/tools have been reinforced in the field of prevention, intervention and compensation (see Table 1 in the appendix), advancing France's strong compensation tradition (Thibert, 2013). The overview of measures shows there were many opportunities for cross-sectorial multi-professional and/or multi-agency cooperation at the school/local level in relation to ESL that also included external partners to offer more personalised and transversal responses.

The main policies and measures involved: (1) fighting against absenteeism; (2) supporting the integration of migrants (test of scholarly and linguistic competencies and provision of support for instruction language); (3) preventing school drop-out for socially disadvantaged youth (priority ECEC enrolment, additional teacher in schools in disadvantaged areas, individualised pedagogical support); (4) ensuring adequate orientation of students, especially in VET; (5) specific structures (MLDS - Missions de lutte contre le décrochage scolaire) that identify youngsters who dropped out of school and offer them different options; and (6) local associations (Missions locales pourl'insertion des jeunes) that provide professional and social integration support to ESL youngsters (EC/EACEA/Eurydice/Cedefop, 2014). Since 2011, a detection system (SIEI, an interdepartmental system of information exchange) has made it possible to identify young school leavers. Data are used by local platforms to identify ESLers and support them in finding a solution (a personalised return path) for further education and training (EC, 2013). It should be noted that SIEI is not used to collect statistical data on ESL (EC/EACEA/Eurydice/Cedefop, 2014).

Moreover, in the reforms taking place in 2013 (see Guidance and Programming Law, 2013-595; also see Eurydice, n.d.) a significant measure was Formation Qualification Emploi (FoQualE), a network that coordinates stakeholders working at the local level with ESLers (different organisations offering education and training programmes outside the regular mainstream education system); it aims to offer a personalised return path to education and training. Another measure was the introduction of 'ESL officers' (décrochage scolaire) who are appointed in secondary schools with 
high truancy and ESL rates. They coordinate the prevention action taken by the education staff, including the CPE and social and health staff, within ESL-prevention groups. The third measure was related to truancy as an early sign of potential school leaving. Some other important measures were (for a detailed description, see Eurydice, n.d.): families are given the final decision regarding the type of lycée a student will attend (to avoid unwanted streaming to vocational programmes linked to ESL; Bavoux \& Pugin, 2012), a website where ESLers can find information regarding training was set up (http://www.onisep.fr/), an advisory phone number for (potential) ESLers or parents about training solutions was made available, versatility in training and flexibility for tracks was increased, external partners were included in educational alliances to offer more personalised and transversal responses, a plan to educate education staff on ESL was developed etc.

Altogether, over 30 policies were implemented with numerous local projects or initiatives (also see Guigue, 2013) and the coexistence of different type of actors (government departments, local governments and local structures/networks). Numerous measures and instruments were loosely coordinated, quickly outdated, decommissioned and scarcely financed at the national/systemic level (Berthet \& Simon, 2012). The collision of national and local agenda has impacted and sometimes destroyed local experimentations (ibid.). The authors also find that the voice of the students in these projects was not heard (pupils had no information about the projects, projects bore no value to them, they were forced to participate), sometimes also due to constraints in the education system (not enough places at the chosen school).

In 2014, the Ministry of Education prepared an evaluation of the partnership policy against ESL and proposed a systemic action plan (MEN, 2014, a, b). A coordinated and coherent action public policy to prevent ESL was launched in November 2014 in the form of a national strategy to tackle ESL (Tous mobilisés contre le décrochage - Together against ESL; MEN, 2015b). The strategy brought different ESL policies and measures together, and systemised them along three key areas. According to the strategy (MEN, 2015b) the three key areas are:

(1) all mobilised against ESL (accountability/empowerment of all actors - schools, teachers, educational non-teaching staff, parents, youth, external actors; 'staying in school is everyone's business, and every young person needs daily encouragement'); 
(2) more emphasis on prevention (ESL modules in initial and in-service staff training, educational alliances between schools and external partners to provide adequate support, new teaching practices and learning methods); and

(3) a "new chance» to become qualified; i.e. return to education or training (greater modularity and flexibility of the education path).

The strategy further defines specific measures within each key area, conditions (levers) needed for the success of the strategy and timeline. In the following section, we present the two measures/actions most related to the multi-professional collaboration in the focus of the TITA project - the ESL-prevention groups and the ESL officer.

\section{ESL-Prevention Group - an example of multi-professional collaboration}

The GPDS (Group de Prévention du Décrochage scholaire - ESL-Prevention Group) is the prototype of multi-professional collaboration which is in the focus of the TITA project. It is a collegial internal (within-institution) multi-category body (MEN, 2015c). The GPDS is a measure/action aimed at students showing signs of ESL (at collège and lycée), previously known as GAIN (Groupe d'Aide à l'Insertion - Integration Support Group; MEN, 2014a).

In the national strategy against ESL (MEN, 2015b) the GPDSs are embedded in the key area of prevention, in the measure of strengthening collaboration between teaching and educational staff to provide better support for young people in an ESL situation; thus the GPDS is focused on within-school collaboration.

The national strategy against ESL allows/aims for the proliferation of ESL-prevention groups in all secondary schools (MEN, 2015b). It is a group around the head of an institution bringing participants of the educational community together: school management, teaching staff, the CPE, the guidance counsellor, the social and health worker. They are brought together in order to analyse the situation of a youngster and find suitable support (MEN, 2014a). The GPDS coordinates the identification of the potential ESL and monitors the implementation of prevention activities (MEN, 2015c). The ESL-prevention groups should be managed and steered by the head of the institution/school directors or the ESL coordinator (national education inspector); however, this role needs to be consolidated in the coming years 
(MEN, 2014b). The ministry (ibid.) has identified the following three priority domains to be systematically addressed by the ESL-prevention group:

(1) the existence of cognitive (learning) difficulties;

(2) diagnostic of possible disorders, pathology or disease (e.g. school phobia); and

(3) attention to harassment (maltreatment or abuse in all forms, inside and outside of school).

Diagnostic tools for identifying ESLers remain to be generalised (MEN, 2015b); guidelines for sharing information and confidentiality have been issued (see MEN, 2015c).

The ESL-prevention groups are closely linked to the establishment of educational alliances, which has been put forward in the national strategy (MEN, 2015b), followed by an implementation guide for educational alliances (MEN, 2015C). The ESL-prevention groups can be seen as an internal educational alliance (micro-level and meso-level) since alliance can be internal to the school (institution) or can include a variety of external partners (macro level; associations, communities, companies from social, medical, health, legal services/institutions to entrepreneurships) (MEN, 2015C; Thibert, 2013). The alliance (thus also the ESL-prevention group) can vary in its configuration according to each student's needs in both its composition and scope (ibid.).

\section{A case study of an ESL-prevention group at Lycée Arago}

To provide a concrete example of how ESL-prevention groups may function, a case study of an ESL-prevention group at Lycée Arago is presented below. Its functions or main goals are to:

- $\quad$ encourage/ensure that the student is present at school and to limit ESL;

- $\quad$ promote the social integration of all students at Lycée Arago;

- $\quad$ empower and encourage the initiative and innovation of all actors; and

- $\quad$ personalise the orientation paths (Lycée Arago, 2015).

Besides these goals, the ESL-prevention group also sets specific goals each year (in line with specific problems of this school and its area). In a Lycée Arago document, the ESL-prevention group's actions are divided 
into four categories: prevention actions aimed at all students, actions to tackle absenteeism, actions aimed at parents, and actions aimed at teachers. The ESL-prevention group is also a body that receives a student as a final resort before outsourcing to local institutions working with school leavers and alerting the academic inspector. However, there is no information about the extent of these different categories or the evaluations of the actions; in this respect, the TITA project will contribute to the examination and evaluation of the actions taken by ESL-prevention groups in different schools.

Lycée Arago's phases of working with or managing (a potential) ESLer are: when everyday alerting signals appear (e.g. continuing absences, frequent delays, exclusion from classes, fatigue/irritation, violence, aggression, avoidance strategies, poor school results) this alerts the CPE, class teacher and ESL officer. This leads to opening an ESL-prevention file, diagnosing the situation, taking care of the student in terms of his/her situation, proposing solutions and monitoring the student (weekly reports). If measures are ineffective, the ESL-prevention group examines the file, analyses the motives of failure, prescribes other solutions, monitors the student (weekly reports). If these measures are ineffective, the institution resorts to outsourcing (it refers the student to external institutions working with early leavers) (Lycée Arago, 2015). This protocol may make these actions appear easier than in everyday school life (some real situations can be observed on the TITA website in the framework of Training Tools).

\section{Teachers in the ESL-prevention group}

According to the ministry, the GPDSs include few teachers, while their participation would allow the link between learning ('school life') and pedagogy to be enhanced (MEN, 2014a). Further, since there is a lack of national guidance and harmonisation the GPDSs' profiles and practices remain diverse (ibid.). In a very recent evaluation of ESL-prevention groups, the authors interviewed over 120 schools' management teams from three regional education authorities (academies) and confirmed this - collaborative work within ESL-prevention groups takes a variety of forms at the individual school level (differences in practices and modes of organisation); however, a large share of schools does include teachers in ESL-prevention groups (Maillard, Merlin, Rouaud, \& Olaria, 2016). More specifically, the authors found four types of collaborative work within ESL-prevention groups in French secondary schools. These four approaches mostly differ by how well 
teachers are mobilised within the group, how broad the conception of prevention is and to what extent actors outside of school are involved. The authors conclude that the involvement of teachers is a key element of multi-professional collaboration because this will lead to a shared vision of what an individual school wants and is able to do. In our opinion, it is important to note that while including teachers in ESL-prevention groups is certainly a necessary step, this in itself does not ensure effective multi-professional collaboration - issues like time and budgetary constraints as well as group composition and training must be considered.

\section{ESL officer}

ESL officers (référent décrochage) were appointed in autumn 2013 at secondary schools with high levels of truancy and ESL (Bulletin officiel, 2013). They have been generalised since August 2014 when a decree was issued that allowed for the appointment of an ESL officer within each secondary school (MEN, 2014b).

The work of ESL officers is situated in the centre of the ESL-prevention measure. From the first signs of ESL onwards, they mobilise and coordinate the prevention action conducted by the ESL-prevention group. The ESL officer takes action under the head of institution alongside other members of the ESL-prevention group. The ESL officer is active in four work areas: prevention axis (e.g. identifies the youngsters concerned from the first signs of ESL onwards, collects all useful information), compensation axis (e.g. involved in research of solutions for a return to initial education and ensures a youngster is monitored (care, support, etc.)), communication (conveys and ensures the circulation of information between actors - management team, CPE) and evaluation (e.g. writing the annual report of proposed actions) (Académie Poitiers, n.d./a). In the prevention axis, their work includes help in setting up the ESL-prevention group; the ESL officer is also its joint-coordinator (ibid.). ESL officers have various profiles - generally they are CPEs, but not always - they can also be e.g. heads of institutions, education assistants, guidance counsellors (Académie Poitiers, n.d./b; MEN 2014b). The ministry aims to assure the promotion of teaching staff in the ESL officer role, formalisation of a dedicated job description for an ESL officer, an increase in their competencies focused on ESL-prevention, enhancement of their role as the link among the actors involved (inside and outside of school, horizontally and vertically with local authorities). 


\section{Conclusions}

This overview of European and French national and local policy and/or operational documents on ESL demonstrates the considerable attention this issue has received in France in recent years. The declining ESL rates show that the efforts have been efficient to some extent; however, tackling the disparities among regions and subgroups remains a challenge.

With regard to multi-professional collaboration in tackling ESL it can be concluded that ESL-prevention groups are a promising measure. In the future, raising the awareness of all actors involved and empowering teachers to be partners on an equal footing in these groups is warranted. Moreover, issues like time and budgetary constraints as well as group composition and training need to be considered. Although the official documents imply that ESL-prevention groups are essentially internal alliances composed of school staff, practice shows that in some schools the functioning and linking of the ESL-prevention group has been extended to include external partners, institutions (Maillard et al., 2016). This indicates that in some schools the ESL-prevention group is already taking the form of a macro-level educational alliance.

It seems that in the following years the challenge with multi-professional collaboration will be to put into practice what has been envisioned in the national strategy and supporting documents. As already mentioned, an important step towards that goal is to evaluate their functioning in practice, as is being conducted within the framework of the TITA project.

\section{References}

Académie Poitiers. (n.d.,a). Les missions principales du référent décrochag. Retrieved from http://www.onisep.fr/Media/Regions/ Poitou-Charentes/Fichiers/tous-nos-pdf/Axe-academique/ les-missions-et-outils-du-referent-decrochage/(language)/fre-FR

Académie Poitiers. (n.d.,b). Mise en cuvre de la politique de lutte contre le décrochage scolaire dans l'académie. Retrieved from http://etab.ac-poitiers.fr/ bassin-sud79/IMG/pdf/presentation_finale_outils_pour_remedier_lutter_ contre_le_decrochage_v2403.pdf

Bavoux, P., \& Pugin, V. (2012). Étude exploratoire sur les jeunes décrocheurs. Lyon: AFEV.

Bernard, P., \& Venart, A. (2013). Décrochages, raccrochages: des concepts à l'action. Administration \& Éducation, 137, 7-8 
Bernard, P. (2013). Le décrochage scolaire: l'émergence et la construction d'un problème scolaire. Administration \& Éducation, 137, 9-16.

Berthet, T. (2013). La gouvernance chaotique des politiques de lutte contre le décrochage: retour sur deux expériences régionales. Administration \& Éducation, 137, 51-58.

Bulletin officiel. (2013). Réseaux Formation Qualification Emploi (FOQUALE) Mise en place circulaire n $^{\circ} 2013-035$ du 29-3-2013 (NOR MENE1306159C). Retrieved from http://www.education.gouv.fr/pid285/bulletin_officiel. html?cid_bo=71326

Dubet, F. (2015). Why has early school leaving become an issue? Overview of socio-economic insights. Keynote speech at Luxembourg EU Presidency Symposium Staying on track Tackling early school leaving and promoting success in school. Luxembourg, 9 and 10 July 2015. Retrieved from http:// www.eu2015lu.eu/en/agenda/2015/o7/o9-10-conf-education-decrochage/o7o9-10-Staying-on-track---Programme-EN-update2.pdf

EC (European Commission). (2013). Education and Training Monitor 2013. France. Retrieved from http://ec.europa.eu/education/tools/docs/ etm2013-country-reports_en.pdf

EC. (2014a). Education and training monitor 2014. Retrieved from http://ec.europa.eu/education/library/publications/monitor14_en.pdf

EC. (2014b). Education and training monitor 2014. France. Retrieved from http://ec.europa.eu/education/tools/docs/2014/monitor2014-fr_en.pdf

EC. (2015). Education and training monitor. 2015. France. Retrieved from http:// ec.europa.eu/education/tools/docs/2015/monitor2015-france_en.pdf

EC/EACEA/Eurydice/Cedefop. (2014). Tackling Early Leaving from Education and Training in Europe: Strategies, Policies, and Measures. Eurydice and Cedefop Report. Luxembourg: Publications Office of the European Union.

EC/EACEA/Eurydice/Eurostat. (2014). Key Data on Early Childhood Education and Care in Europe. 2014 Edition. Eurydice and Eurostat Report. Luxembourg: Publications Office of the European Union.

Eurostat. (2016a). Early leavers from education and training by sex. France. Graph. Retrieved from: http://ec.europa.eu/eurostat/tgm/drawGraph. do? type $=$ PDF \& title $=$ true\&legend $=$ true $\&$ download =Eurostat_Graph_ t2020_40.pdf

Eurostat. (2016b). Early leavers from education and training by sex. France. Table. Retrieved from: http://ec.europa.eu/eurostat/tgm/web/_download/ 
Eurostat_Table_t2020_40PDFDesc_389e83b4-eeo6-471e-8f62-68eaafo47310. pdf

Eurostat database. (n.d.) Retrieved from http://ec.europa.eu/eurostat/data/database edat_lfse_14, edat_lfse_16

Eurydice. (2014). The Structure of the European Education Systems 2014/15:

Schematic Diagrams. Retrieved from:http://eacea.ec.europa.eu/education/ eurydice/documents/facts_and_figures/education_structures_EN.pdf

Eurydice. (n.d.). Countries - description of national education systems. Retrieved from: https://webgate.ec.europa.eu/fpfis/mwikis/eurydice/index.php?title=Home

Guidance and Programming Law no 2013-595 of 8 July for Restructuring Schools (LOI $\mathrm{n}^{\circ}$ 2013-595 du 8 juillet 2013 d'orientation et de programmation pour la refondation de l'école de la République). Retrieved from http://www.legifrance.gouv.fr/affichTexte. do? cidTexte=JORFTEXToooo $27677984 \&$ dateTexte $=\&$ categorieLien $=$ id

Guigue, M. (2013). La question du décrochage, entre mutations institutionnelles et initiatives locales. Retour sur des expériences innovantes en collège. Administration \& Éducation, 137, 93-99.

Huart, J. (2013). La lutte contre le décrochage scolaire. Administration \& Éducation, 137, 17-22.

Lycée Arago. (2015). Groupe de prévention du décrochage scolaire. Retrieved from http://lycee-arago.fr/sites/default/files/storage/Utilisateurs/admin/ GPDS/GPDS\%2oARAGO.pdf

Maillard, D. Merlin, F., Rouaud, P., \& Olaria, M. (2016). How do education professionals cooperate to tackle early school leaving. Training of Employment, 122, 1-4.

MEN (Ministère éducation nationale) (2014a). Évaluation partenariale de la politique de lutte contre le décrochage scolaire. Rapport de diagnostic, Mars 2014. Retrieved from http://cache.media.education.gouv.fr/file/2014/85/8/ Rapport-Evaluation-partenariale-de-lutte-contre-le-decrochagescolaire_331858.pdf

MEN (Ministère de l'éducation nationale, de l'enseignement supérieur et de la recherché). (2014b). Évaluation partenariale de la politique de lutte contre le décrochage scolaire. Rapport final, November 2014. Retrieved from http://cache.media.education.gouv.fr/file/2014/24/2/MAP_Decrochage_ Rapport_final_369242.pdf

MEN (Ministère de l'éducation nationale, de l'enseignement supérieur et de la recherché). (2015a). La lutte contre le décrochage scolaire. Retrieved from 
http://www.education.gouv.fr/cid55632/la-lutte-contre-le-decrochage-scolaire.html

MEN (Ministère de l'éducation nationale, de l'enseignement supérieur et de la recherché). (2015b). Tous mobilisés pour vaincre le décrochage scolaire. Retrieved from http://www.education.gouv.fr/cid84031/tous-mobilises-pour-vaincre-le-decrochage-scolaire.html

MEN (Ministère de l'éducation nationale, de l'enseignement supérieur et de la recherché). (2015c). Guide de mise en ceuvre des alliances éducatives. Retrieved from http://cache.media.education.gouv.fr/file/o8_aout/75/6/20151006_Alliances_educatives_505756.pdf

NESSE (Network of Experts in Social Sciences of Education and Training). (2010). Early school leaving: lessons from research for policy makers. An independent expert report submitted to the European Commission. Retrieved from http://www.nesse.fr/nesse/activities/reports/activities/ reports/early-school-leaving-report

PPMI (Public Policy and Management Institute). (2014). Study on the effective use of early childhood education and care in preventing early school leaving. Annex 1. Literature review. Luxembourg: Publications Office of the European Union.

Thibert, R. (2013). Early School Leaving: Different ways to deal with it. Dossier d'actualité Veille et Analyses IFÉ, 84. Lyon: ENS de Lyon. Retrieved from http://ife.ens-lyon.fr/vst/DA-Veille/84-may-2013_EN.pdf 


\section{Appendix}

Table I. Principal measures/institutions/networks/tools of the policy against ESL (translated from MEN, 2014a)

\begin{tabular}{|c|c|c|c|c|c|}
\hline Field & $\begin{array}{l}\text { Title (French } \\
\text { original // English } \\
\text { translation }\end{array}$ & Type of policy & Target public & Synthetic description & Policy carrier \\
\hline \multirow{7}{*}{ 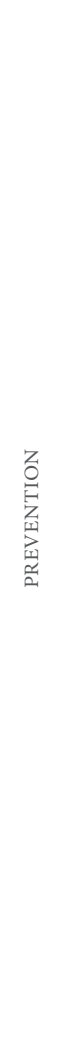 } & $\begin{array}{l}\text { Accompagnement } \\
\text { éducatif// Educati- } \\
\text { onal support }\end{array}$ & measure/action & $\begin{array}{l}\text { volunteer students } \\
\text { of Priority Edu- } \\
\text { cation }^{1}\end{array}$ & $\begin{array}{l}\text { receive the students after school to } \\
\text { propose help with their homework } \\
\text { and lessons, to strengthen their pra- } \\
\text { ctice of modern languages, cultu- } \\
\text { ral and artistic activities or sports } \\
\text { activity }\end{array}$ & $\begin{array}{l}\text { Ministry of } \\
\text { Education } \\
\text { (MoE) }\end{array}$ \\
\hline & $\begin{array}{l}\text { Aide personnalisée } \\
\text { // Personalised help } \\
\text { (replaced by addi- } \\
\text { tional pedagogical } \\
\text { activities) }\end{array}$ & measure/action & $\begin{array}{l}\text { primary school } \\
\text { students (6-11 ye- } \\
\text { ars old) }\end{array}$ & $\begin{array}{l}\text { 6o hours per school year that the tea- } \\
\text { cher dedicates to accompany smaller } \\
\text { groups of students }\end{array}$ & MoE \\
\hline & $\begin{array}{l}\text { Conseil École-Col- } \\
\text { lège // School }{ }^{2} \text {-col- } \\
\text { lège board }\end{array}$ & measure/action & $\begin{array}{l}\text { students of } 5 \text { th and } \\
6 \text { th classes }\end{array}$ & $\begin{array}{l}\text { a body uniting boards and scho- } \\
\text { ol/collège teachers of the sector and } \\
\text { preparing an action programme } \\
\text { with the aim to improve the peda- } \\
\text { gogical and educational continui- } \\
\text { ty between the primary school and } \\
\text { collège }\end{array}$ & MoE \\
\hline & $\begin{array}{l}\text { Dispositif d'inita- } \\
\text { tion aux métiers en } \\
\text { alternance (DIMA) } \\
\text { // Measure of initi- } \\
\text { ation in work-lin- } \\
\text { ked professions }\end{array}$ & measure/action & $\begin{array}{l}\text { students over } 15 \\
\text { who want to enter a } \\
\text { training }\end{array}$ & $\begin{array}{l}\text { discovering one or several professi- } \\
\text { ons as part of work-linked educati- } \\
\text { on, while also acquiring a common } \\
\text { base of knowledge }\end{array}$ & $\mathrm{MoE}$ \\
\hline & $\begin{array}{l}\text { Ecole Ouverte // } \\
\text { Open School }\end{array}$ & institution & $\begin{array}{l}\text { young people who } \\
\text { cannot go on ho- } \\
\text { liday }\end{array}$ & $\begin{array}{l}\text { opening of voluntary institutions of } \\
\text { deprived areas or rural zones during } \\
\text { school holidays as well as on Wed- } \\
\text { nesdays and Saturdays in order to } \\
\text { offer youngsters a programme with } \\
\text { many activities organised by quali- } \\
\text { fied teachers }\end{array}$ & $\begin{array}{l}\text { MoE and city } \\
\text { authorities }\end{array}$ \\
\hline & $\begin{array}{l}\text { Mallette des } \mathrm{Pa} \text { - } \\
\text { rents en } 6 \text { e // } \mathrm{Pa} \text { - } \\
\text { rents' kit/aid in } 6 \text { th } \\
\text { class }\end{array}$ & measure/action & $\begin{array}{l}\text { parents of } 6 \text { th class } \\
\text { students }\end{array}$ & $\begin{array}{l}\text { meeting debates between parents } \\
\text { and collège staff concerning support } \\
\text { they can offer to children, relation- } \\
\text { ship with the collège and compre- } \\
\text { hension of its functioning }\end{array}$ & $\mathrm{MoE}$ \\
\hline & $\begin{array}{l}\text { Mallette des } \mathrm{Pa} \text { - } \\
\text { rents en } 3 \mathrm{e} / / \mathrm{Pa} \text { - } \\
\text { rents' kit/aid in } 3 \text { rd } \\
\text { class }\end{array}$ & measure/action & $\begin{array}{l}\text { parents of } 3 \text { rd class } \\
\text { students who are } \\
\text { academically the } \\
\text { most vulnerable }\end{array}$ & $\begin{array}{l}\text { information and exchange reunions } \\
\text { between the principal and the pa- } \\
\text { rents concerning the student's ori- } \\
\text { entation }\end{array}$ & $\mathrm{MoE}$ \\
\hline
\end{tabular}




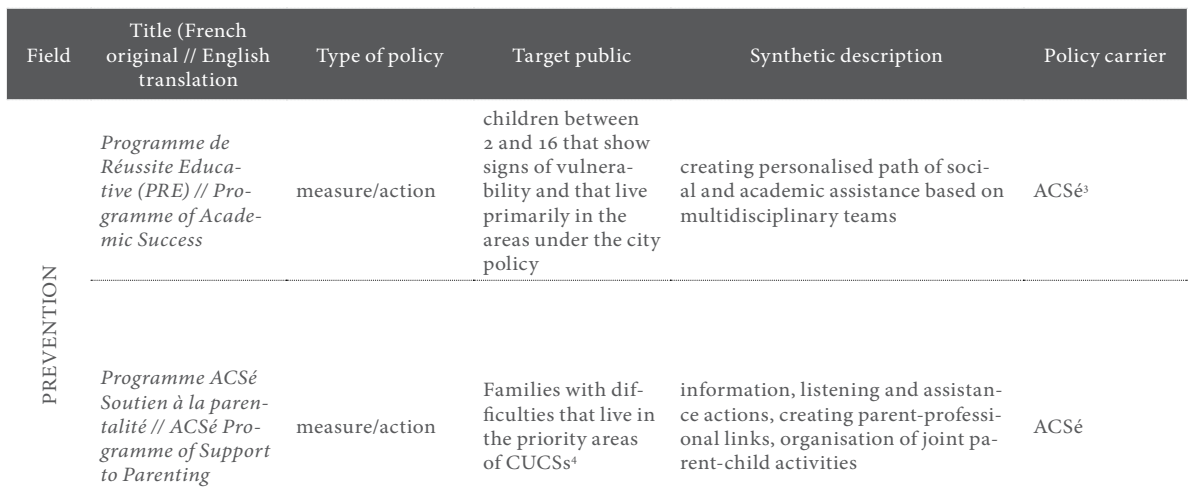

\begin{tabular}{|c|c|c|c|c|c|}
\hline \multirow{7}{*}{ 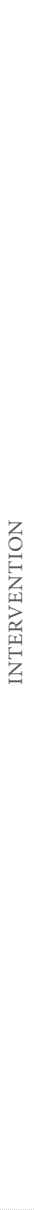 } & $A C T E^{s}$ & measure/action & $\begin{array}{l}\text { students excluded } \\
\text { from collège for a } \\
\text { short period }(<5 \\
\text { days })\end{array}$ & $\begin{array}{l}\text { Taking care of excluded students in } \\
\text { order to encourage academic con- } \\
\text { tinuity and prevent the exclusion } \\
\text { to turn into ESL. The excluded stu- } \\
\text { dents are received out of collège for } \\
\text { an academic and socio-educatio- } \\
\text { nal assistance essentially provided } \\
\text { by specialised teachers: a speci- } \\
\text { al attention is given to the compre- } \\
\text { hension of the sanction and the re- } \\
\text { turn to collège }\end{array}$ & $\begin{array}{l}\mathrm{CG} 93^{6} \text { and } \\
\mathrm{MoE}\end{array}$ \\
\hline & $C N E D^{7}-D^{\prime} \mathrm{Col}^{8}$ & measure/action & $\begin{array}{l}\text { students with scho- } \\
\text { ol difficulties }\end{array}$ & $\begin{array}{l}\text { online school support measure } \\
\text { (French, Maths, English) that com- } \\
\text { bines personal assistance, digital } \\
\text { educational means and an online } \\
\text { tutoring by a CNED teacher }\end{array}$ & MoE - CNED \\
\hline & $\begin{array}{l}\text { Dispositifs relais } \\
\text { (Bride facility/brid- } \\
\text { ging programme) }\end{array}$ & institution & $\begin{array}{l}\text { youngsters with } \\
\text { school and behavi- } \\
\text { our problems, of- } \\
\text { ten in a process of } \\
\text { school institution } \\
\text { rejection }\end{array}$ & $\begin{array}{l}\text { a reinforced educational, school and } \\
\text { pre-school supervision aiming at a } \\
\text { reinvestment of learning, an approp- } \\
\text { riation of social and school rules in } \\
\text { order to return to mainstream edu- } \\
\text { cation }\end{array}$ & MoE \\
\hline & $E R S^{9}$ & institution & $\begin{array}{l}\text { students that were } \\
\text { excluded multiple } \\
\text { times, but who } \\
\text { don't receive a spe- } \\
\text { cial or adapted } \\
\text { education nor are } \\
\text { placed in the penal } \\
\text { system }\end{array}$ & $\begin{array}{l}\text { adapted education for at least a } \\
\text { month, often the student lives in a } \\
\text { residency in the annexed premises } \\
\text { which permits an ongoing care of } \\
\text { the student }\end{array}$ & MoE \\
\hline & $\begin{array}{l}\text { GPDS (Groupe } \\
\text { de Prévention du } \\
\text { Déchochage schola- } \\
\text { ire // ESL-preventi- } \\
\text { on Group) }\end{array}$ & measure/action & $\begin{array}{l}\text { students showing } \\
\text { signs of ESL (essen- } \\
\text { tially collège and } \\
\text { secondary school) }\end{array}$ & $\begin{array}{l}\text { a group around the head of instituti- } \\
\text { on joining all the participants of the } \\
\text { academic community (the teacher, } \\
\text { the } \mathrm{CPE}^{10} \text {, the COP }{ }^{11} \text {, the social wor- } \\
\text { ker...) in order to analyse the situ- } \\
\text { ation of a youngster and find suita- } \\
\text { ble support }\end{array}$ & MoE \\
\hline & $L A T I^{12}$ & institution & $\begin{array}{l}\text { students showing } \\
\text { signs of ESL }\end{array}$ & $\begin{array}{l}\text { reception and pedagogical/educatio- } \\
\text { nal/ psychological care taking place } \\
\text { at the institution }\end{array}$ & MoE \\
\hline & $\begin{array}{l}\text { MAAF-Réseau in- } \\
\text { sertion/égalité des } \\
\text { chances // Mini- } \\
\text { stry of Agricultu- } \\
\text { re-Integration/ } \\
\text { Equal Opportuniti- } \\
\text { es Sector }\end{array}$ & network & $\begin{array}{l}\text { students showing } \\
\text { signs of ESL }\end{array}$ & $\begin{array}{l}\text { assistance of institutions in setting } \\
\text { up actions against ESL at the local } \\
\text { and regional level }\end{array}$ & $\begin{array}{l}\text { Ministry of } \\
\text { Agriculture }\end{array}$ \\
\hline
\end{tabular}




\begin{tabular}{|c|c|c|c|c|c|}
\hline Field & $\begin{array}{l}\text { Title (French } \\
\text { original // English } \\
\text { translation }\end{array}$ & Type of policy & Target public & Synthetic description & Policy carrier \\
\hline \multirow{4}{*}{ 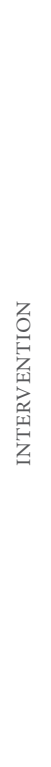 } & $\begin{array}{l}\text { MLDS (Mission } \\
\text { de Lutte conte le } \\
\text { Décrochage Sco- } \\
\text { laire) }\end{array}$ & network & $\begin{array}{l}\text { students showing } \\
\text { signs of ESL (essen- } \\
\text { tially collège and } \\
\text { secondary school) }\end{array}$ & $\begin{array}{l}\text { a body with an educational advice, } \\
\text { expertise and engineering role wit- } \\
\text { hin institutions and CIO (Centre } \\
\text { d'Information and Orientation) in- } \\
\text { tended for setting up identification, } \\
\text { prevention, remobilisation and re- } \\
\text { preparation for the exams }\end{array}$ & $\mathrm{MoE}$ \\
\hline & $\begin{array}{l}\text { Programme per- } \\
\text { sonnalisé de } \\
\text { Réussite Educati- } \\
\text { ve (PPRE) // Perso- } \\
\text { nalised Programme } \\
\text { of Academic Achie- } \\
\text { vement }\end{array}$ & measure/action & $\begin{array}{l}\text { students with scho- } \\
\text { ol difficulties, from } \\
\text { elementary school } \\
\text { to collège }\end{array}$ & $\begin{array}{l}\text { coordinated action plan develo- } \\
\text { ped by a pedagogic team, discussed } \\
\text { with the parents and presented to } \\
\text { the student }\end{array}$ & MoE \\
\hline & $\begin{array}{l}\text { Réseau d'Ai- } \\
\text { de Spécialisé aux } \\
\text { Elèves (RASED) // } \\
\text { Specialised Support } \\
\text { Network for Stu- } \\
\text { dents }\end{array}$ & network & $\begin{array}{l}\text { students with scho- } \\
\text { ol or school adapta- } \\
\text { tion difficulties in } \\
\text { primary school }\end{array}$ & $\begin{array}{l}\text { a specialised support in and out of } \\
\text { class, provided by specialised tea- } \\
\text { chers intended for a predominantly } \\
\text { pedagogical aid: the »E teachers« (le- } \\
\text { arning difficulties), specialised te- } \\
\text { achers intended for a predominan- } \\
\text { tly reeducation aid: the G teachers } \\
\text { (school adaptation difficulties) and } \\
\text { school psychologists }\end{array}$ & $\mathrm{MoE}$ \\
\hline & $\begin{array}{l}\text { Stages de remise à } \\
\text { niveau // Update } \\
\text { training sessions }\end{array}$ & measure/action & $\begin{array}{l}\text { students with scho- } \\
\text { ol difficulties in } \\
\text { primary school }\end{array}$ & $\begin{array}{l}\text { The sessions are taking place in } \\
\text { smaller groups during school ho- } \\
\text { lidays and targeting learning of } \\
\text { French and Maths. They are pro- } \\
\text { posed to families and hosted by vo- } \\
\text { luntary teachers that are paid by } \\
\text { extra hours }\end{array}$ & $\mathrm{MoE}$ \\
\hline \multirow{5}{*}{ 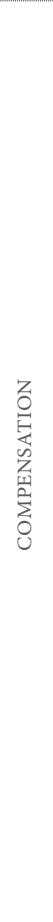 } & $\begin{array}{l}\text { Atelier pédagogique } \\
\text { de Nanterre (Peda- } \\
\text { gogic Workshop of } \\
\text { Nanterre) }\end{array}$ & measure/action & $\begin{array}{l}\text { youngsters betwe- } \\
\text { en } 10 \text { and } 18\end{array}$ & $\begin{array}{l}\text { a flexible, out-of-institution educa- } \\
\text { tion modality bringing together tea- } \\
\text { chers, educators and an infant-child } \\
\text { psychiatric ward }\end{array}$ & $\begin{array}{l}\text { T. Roussel } \\
\text { Hospital Cen- } \\
\text { tre, MoE and } \\
\text { associations }\end{array}$ \\
\hline & $C I V I S^{13}$ & measure/action & $\begin{array}{l}\text { youngsters from } 16 \\
\text { to } 25 \text { without a di- } \\
\text { ploma or job se- } \\
\text { ekers }\end{array}$ & $\begin{array}{l}\text { A one-year measure aimed to enco- } \\
\text { urage professional integration on } \\
\text { a youngster thanks to a personali- } \\
\text { sed assistance that can be doubled } \\
\text { by an allowance. A reinforced mea- } \\
\text { sure (weekly meetings the first three } \\
\text { months) is intended for youngsters } \\
\text { of VI, Vbis and V without a diploma } \\
\text { (11 to } 17 \text { year olds). }\end{array}$ & $\begin{array}{l}\text { Emploi (a set of } \\
\text { public policies } \\
\text { regarding work } \\
\text { and vocational } \\
\text { training) }\end{array}$ \\
\hline & $\begin{array}{l}\text { Clauses sociales // } \\
\text { Social provisions }\end{array}$ & measure/action & $\begin{array}{l}\text { youngsters that } \\
\text { dropped out }\end{array}$ & $\begin{array}{l}\text { Experimental measure involving in- } \\
\text { tegration of provisions in public } \\
\text { markets of National Education in or- } \\
\text { der to enable young ESLers to do an } \\
\text { integration career within a company } \\
\text { completed by a monitoring by MLDS } \\
\text { in order to create a professional pro- } \\
\text { ject/career plan. }\end{array}$ & $\mathrm{MoE}$ \\
\hline & $\begin{array}{l}\text { Ecoles de la } 2 e \\
\text { Chance // Schools } \\
\text { of } 2 \text { nd Chance }\end{array}$ & institution & $\begin{array}{l}\text { voluntary youn- } \\
\text { gsters that often } \\
\text { have a difficult re- } \\
\text { lationship with } \\
\text { school, i.e. behavi- } \\
\text { our problems }\end{array}$ & $\begin{array}{l}\text { a training programme aimed to cre- } \\
\text { ate a professional project/career plan } \\
\text { for every youngster by offering indi- } \\
\text { vidualised paths/careers, numerous } \\
\text { contacts with the companies and a } \\
\text { required level of essentials }\end{array}$ & $\begin{array}{l}\text { Network of } \\
\text { Ecoles de la } 2 \mathrm{e} \\
\text { Chance }\end{array}$ \\
\hline & Centres EPIDE ${ }^{14}$ & institution & $\begin{array}{l}\text { youngsters from } 18 \\
\text { to } 25 \text { that lag be- } \\
\text { hind or experien- } \\
\text { ce school difficul- } \\
\text { ties and frequently } \\
\text { have financial and } \\
\text { health problems } \\
\text { and problems with } \\
\text { the law }\end{array}$ & $\begin{array}{l}\text { A teaching method from } 8 \text { to } 24 \\
\text { months, exclusively provided un- } \\
\text { der the scheme of residency during } \\
\text { the week. The programme combi- } \\
\text { nes working in depth on the know- } \\
\text {-how, a general course encompassing } \\
\text { a required school level and creating a } \\
\text { professional project/career plan lea- } \\
\text { ding to employment }\end{array}$ & EPIDE \\
\hline
\end{tabular}




\begin{tabular}{|c|c|c|c|c|c|}
\hline Field & $\begin{array}{l}\text { Title (French } \\
\text { original // English } \\
\text { translation }\end{array}$ & Type of policy & Target public & Synthetic description & Policy carrier \\
\hline \multirow{8}{*}{ 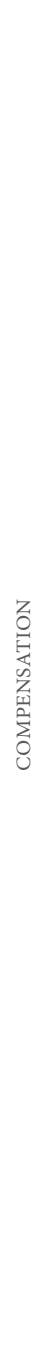 } & $\begin{array}{l}\text { Etablissements Sco- } \\
\text { laires Publics Inno- } \\
\text { vants (ESPI) (Inno- } \\
\text { vative Public School } \\
\text { Institutions) }\end{array}$ & institution & variable & $\begin{array}{l}\text { an institution offering innova- } \\
\text { tive modes of operation putting } \\
\text { an accent on academic achieve- } \\
\text { ment, removing artificial barriers } \\
\text { in teaching/education, developing } \\
\text { a collective and offering individual } \\
\text { assistance to the students }\end{array}$ & $\begin{array}{l}\text { ESPI federation } \\
\text { (FESPI) }\end{array}$ \\
\hline & FOQUALE & network & $\begin{array}{l}\text { youngsters that } \\
\text { dropped out of } \mathrm{Na}- \\
\text { tional Education }\end{array}$ & $\begin{array}{l}\text { a network uniting the participants of } \\
\text { National Education present in a par- } \\
\text { ticular area in order to coordinate } \\
\text { and develop the offer of solutions av- } \\
\text { ailable to young ESLers }\end{array}$ & $\mathrm{MoE}$ \\
\hline & $\begin{array}{l}\text { Ma Seconde Chan- } \\
\text { ce // My Second } \\
\text { Chance }\end{array}$ & tool & $\begin{array}{l}\text { students in the pro- } \\
\text { cess of dropping } \\
\text { out or that already } \\
\text { dropped out }\end{array}$ & $\begin{array}{l}\text { an internet site and a mobile appli- } \\
\text { cation providing the youngsters that } \\
\text { dropped out the initial education } \\
\text { the nearest reception and education } \\
\text { place that is adapted to their wishes } \\
\text { thanks to the information, geoloca- } \\
\text { lisation and dialogue (chat) services }\end{array}$ & $\begin{array}{l}\text { MoE - ONI- } \\
\text { SEP }^{15}\end{array}$ \\
\hline & $\begin{array}{l}\text { Micro-lycées // Mi- } \\
\text { cro-students }\end{array}$ & institution & $\begin{array}{l}\text { youngsters that } \\
\text { dropped out volu- } \\
\text { ntarily, often with } \\
\text { complex paths and } \\
\text { without education } \\
\text { solution }\end{array}$ & $\begin{array}{l}\text { An innovative and experimental } \\
\text { programme offering preparation } \\
\text { for baccalaureate (secondary scho- } \\
\text { ol diploma). Its objective is that the } \\
\text { youngsters return to learning, ru- } \\
\text { les, socialisation and to adopt self- } \\
\text {-confidence. }\end{array}$ & MoE \\
\hline & $\begin{array}{l}\text { Missions Locales // } \\
\text { Local Missions }\end{array}$ & network & $\begin{array}{l}\text { youngsters from } 16 \\
\text { to } 25 \text { having pro- } \\
\text { blems with soci- } \\
\text { al and professional } \\
\text { integration }\end{array}$ & $\begin{array}{l}\text { Spaces of intervention in the servi- } \\
\text { ce of youngsters. Their functions are } \\
\text { identification, information, orienta- } \\
\text { tion and assistance. }\end{array}$ & $\begin{array}{l}\text { Emploi (a set of } \\
\text { public policies } \\
\text { regarding work } \\
\text { and vocational } \\
\text { training) }\end{array}$ \\
\hline & $\begin{array}{l}\text { Plateformes de So- } \\
\text { utien et d'Appui } \\
\text { au Décrocheu- } \\
\text { rs (PSAD) //ESL } \\
\text { Support Platforms }\end{array}$ & network & $\begin{array}{l}\text { youngsters that } \\
\text { dropped out }\end{array}$ & $\begin{array}{l}\text { a coordination measure bringing to- } \\
\text { gether local education, orientation } \\
\text { and integration participants/players } \\
\text { aimed at providing a personalised } \\
\text { and quick answer to every youn- } \\
\text { gster without a diploma and witho- } \\
\text { ut solution }\end{array}$ & $\begin{array}{l}\text { Partnership } \\
\text { (MoE and the } \\
\text { Emploi work } \\
\text { policies) }\end{array}$ \\
\hline & $\begin{array}{l}\text { Service civique // } \\
\text { Civic Service }\end{array}$ & measure/action & $\begin{array}{l}\text { youngsters from } \\
16 \text { to } 25\end{array}$ & $\begin{array}{l}\text { a voluntary commitment in order to } \\
\text { perform a common good task dou- } \\
\text { bled by a personalised monitoring of } \\
\text { the young ESLer by a National Edu- } \\
\text { cation tutor }\end{array}$ & $\begin{array}{l}\text { Agency of Ci- } \\
\text { vil Service and } \\
\text { MoE }\end{array}$ \\
\hline & $\begin{array}{l}\text { Système Intermi- } \\
\text { nistriel d'Echan- } \\
\text { ge d'Informations } \\
\text { (SIEI)// Intermi- } \\
\text { nistrial system of } \\
\text { exchange of infor- } \\
\text { mation }\end{array}$ & tool & $\begin{array}{l}\text { youngsters over } 16 \\
\text { that dropped out } \\
\text { different systems } \\
\text { of initial education } \\
\text { (currently tracking: } \\
\text { National Educa- } \\
\text { tion, Agricultu- } \\
\text { re, private schools, } \\
\text { Apprentice Tra- } \\
\text { ining Centre) }\end{array}$ & $\begin{array}{l}\text { an information system providing an } \\
\text { insight into student files and thus } \\
\text { identifying twice a year the youn- } \\
\text { gsters that dropped out from diffe- } \\
\text { rent initial education systems }\end{array}$ & $\begin{array}{l}\text { MoE and Mi- } \\
\text { nistry of Agri- } \\
\text { culture }\end{array}$ \\
\hline
\end{tabular}

1 Priority Education Zones are areas of school institutions (primary schools or collèges) in France with greater autonomy or resources in order to fight against difficulties of the school or social order. Since 2006 they no longer exist under this name although it has become a well-known expression in France. Priority Education is a government policy targeting schools with learning and social difficulties.

2 Meaning primary school

3 Agence nationale pour la Cohésion Sociale et l'Égalité des chances // National Agency for Social Cohesion and Equal Opportunities 
4 Contrat Urban de Cohésion Sociale // Urban Contract of Social Cohesion: a measure of French city policy between 2007 and 2014 in order to help areas with difficulties; when it expired in 2014, it was replaced in 2015 by 1300 Quartiers prioritaires (QP) // 1,300 Priority Areas in accordance with an election promise made by President Hollande

5 Accompagnement des Collégiens Temporairement Exclus // Assistance to Temporarily Excluded Students

6 Conseil Général de Seine-Saint-Denis // General Board of Seine-Saint-Denis department

7 Centre National d'Enseignement à Distance // National Centre for Distance Learning

8 Interactive assistance and support system of CNED

9 Établissement de Réinsertion Scolaire // Academic Reintegration Institution: an institution introduced in 2010 for disruptive students aged between 13 and 16

10 Conseiller Principal d'Education // Principal Education Advisor: a special feature of the French education system

11 Conseiller d'Orientation-Psychologue // Guidance Counsellor-Psychologist

12 Lieu d'Accueil Temporaire Individualisé // Individualised Temporary Reception Place

13 Contrat d'Insertion dans la VIe Sociale // Social Life Integration Contract

14 Etablissement Pubic d'Insertion de la Defense // Public Institution of (Social) Defence Integration

15 Office National d'Information Sur les Enseignants et les Professions // National Information Office for Teachers and Professions 


\section{I.3}

\section{The ESL Situation in Luxembourg}

Maša Vidmar and Tina Rutar Leban

\section{Synopsis}

Since 2000, rates of ESL in Luxembourg have stayed below the European and national target of $10 \%$, with some fluctuations seen in recent years. However, ESL among students with a migrant background remains a challenge. Education and career guidance is very well developed and is clearly regarded as tackling ESL. Multiprofessional teams in and around schools are well established.

\section{Summary}

Luxembourg and its education system are characterised by a multilingual environment with three official languages and relatively high levels of migrants. Luxembourg already had relatively low rates of ESL in 2000 compared to other EU member states, but still made considerable progress up to 2009 , with an ESL rate of $7.7 \%$. Since then, slight fluctuations may be observed; the country's ESL rate remained below the European headline target of 10\% throughout this period, reaching its lowest rate of 5.5\% in 2015. The share of early leavers is higher for foreign-born versus native-born and for male versus female. ESL in Luxembourg has received significant attention since 2000, with the issue considered in the extensive ongoing reform of the country's education system. The following measures are recognised as important for tackling ESL. First, Luxembourg has a tradition of education and career guidance as well as a multi-agency 
partnership working in and around schools, providing good tools also with regard to ESL. The multi-agency teams involve school heads, teachers, guidance specialists, psychologists, social workers, youth workers and therapists. Every school in secondary education provides a service for educational psychology and guidance (SPOS) which cooperates with teachers, parents, the school's medical service, as well as competent services and professional chambers. Education and career guidance ${ }^{\mathrm{I}}$ is explicitly seen as a prevention, intervention and compensation measure for addressing ESL. Second, the role of second-chance schools has also been put forward. Third, the ESL topic is included in continuing professional development courses. Finally, several other practices (e.g. a digital register of students that allows ESLers to be followed up and given help to enter an appropriate training programme or the labour market; 'Mosaic Classes' for students with behavioural difficulties; the 'Stop\&Go' self-development programme) and projects (e.g. the PAS project that helps identify at-risk students and applies measures; the 'Itzigerstee' project for highly problematic students) have been established, although a comprehensive national strategy tackling ESL is still lacking. Moreover, as MENJE (2015) highlighted, it is clear that in general high schools (lycées) only respond to ESL once it is already obvious; instead, timely attention to early causes and pathways is needed, namely at the start of the process that ends in ESL, and to invest more in preventing ESL.

Key words: Luxembourg, policy measures, ESL statistics, education and career guidance, multi-professional teams

\section{Introduction}

Following Europe's strategy within the framework Education \& Training 2010 (European Commission, 2002) and 2020 (Council of the EU, 2009), the reduction of early school leaving (ESL) has become an important issue in Luxembourg. The issue has also attracted political attention since over $40 \%$ of youth who were in unemployment had no qualifications (Cedefop, 2014). ESL has been addressed in a comprehensive reform of the national tion and career guidance (for the exact definition, see ELGPN, 2014, p. 14). 
education system, with various measures at either national or local level being articulated to prevent or remedy ESL.

The aim of this article is to describe the current situation and recent trends concerning ESL in Luxembourg. First, some characteristics of Luxembourg's education system relevant to ESL are presented (i.e. transitions, length of compulsory education, grade retention), including certain pertinent recent reforms. Second, statistics on ESL in Luxembourg are provided along with, third, an insight into some ESL-related measures and policies with a focus on multi-professional collaboration relating to ESL. The purpose is to elucidate the context in which experiments within the TITA project take place, thus guiding the interpretation and generalisations of the findings.

\section{Methodology}

The findings outlined in this article are based on information drawn from European documents (European Commission, Eurydice), Eurostat, ministerial documents on ESL, and other documents and reports available online. A search for scientific articles using the key words "early school leaving", "drop-out" and "Luxembourg" using the Arizona State University Libraries search engine resulted in only two relevant articles. This lack of international scientific publications and findings pertaining to the ESL topic in Luxembourg indicates it has not received much research attention; thus, for this article's purposes we mostly relied on the documents listed above. A search was also conducted using the backward procedure.

\section{Some relevant characteristics of Luxembourg's education system}

Due to its relatively small territory and geographical location, Luxembourg's demographic situation is characterised by a multinational population and workforce as well as a multilingual environment. Naturally, this holds implications for the education system (Eurydice, n.d.). For example, in 2004/2005, pupils speaking Luxembourgish at home made up the majority, but by 2012/2013 the situation had reversed: just $40 \%$ of pupils speak Luxembourgish as a first language at home (MENJE, 2014). Moreover, over $30 \%$ of students in primary education do not speak any of the three official languages - French, German or Luxembourgish (neither as the first language spoken, nor the second language spoken; ibid.). This trilingual tradition is 
an asset for the national education system. However, it also makes life more difficult for many students, bringing about the possibility of ESL (European Commission, 2016a, b; also see Meyers \& Houssemand, 2011 for a discussion on language education in Luxembourg; see MENJE, 2015 for the reasons for ESL identified by actual ESLers). Moreover, the high rates of students with a migrant background also hold implications for tackling ESL as such students are largely over-represented among ESLers in many EU countries (Eurostat, n.d./b). Yet the relationship between a migrant background and ESL is not straightforward, with other variables (e.g. SES, language) likely playing a role. Another specific characteristic of Luxembourg's education system is the important role of the social partners (i.e. professional chambers, parents' associations) throughout the system - there is a strong presence of social dialogue between the government and various interest groups as well as membership in different bodies and commissions.

Eurydice diagrams of education systems (Eurydice, n.d.; European Commission/EACEA/Eurydice, 2015) show that education in Luxembourg is compulsory between the ages of 4 and 16 . This period comprises elementary school (école fondamentale) and secondary education (enseignement post-primaire) with several transitions and early tracking (after primary level), both of which are recognised as risk factors for ESL at the system level. Elementary school is divided into four cycles (cycles 1-4, including preschool education and primary education, ages 3 to 11 years, ISCED o and 1). After elementary education, students are streamed into secondary education (ages 12 to 19 years, ISCED 2 and 3) which is either: general secondary education (lycée) preparing for higher education or technical secondary education (lycée technique - with three different regimes) preparing for working life and/ or higher education (Eurydice, n.d.). Since the 2016/2017 school year, the process of guidance towards secondary education already starts in the last two years of elementary school (ibid.). Early education and career guidance is recognised as system-level protective factor against ESL.

Another two aspects of the education system touching on ESL are grade retention (a risk factor) and accessible high-quality ECEC; a protective factor). Grade retention in Luxembourg is one of the highest in Europe, with some $35 \%$ of students reporting they had repeated a grade at least once in primary, lower or upper secondary education in 2009 (EACEA/Eurydice, 2011) and in 2012 (European Commission/EACEA/ Eurydice/Cedefop, 2014). ECEC is strong in Luxembourg since over 95\% of children participate in it before they start primary school (European 
Commission/EACEA/Eurydice/Eurostat, 2014) and recent measures aim to improve the quality of these services, particularly to reduce socio-economic disadvantages (European Commission, 2016b). One of the biggest issues in Luxembourg is the strong relationship between SES and educational performance, where SES is, in turn, correlated with migrant background (European Commission, 2016a).

Luxembourg's education system brings a strong emphasis on education and career guidance, (psychological) counselling and information activities available to the students. Guidance is part of the curriculum in primary education; in secondary schools it is not embedded in the curriculum, but schools are obliged to provide it (European Commission/EACEA/ Eurydice/Cedefop, 2014). School staff dealing with guidance comprise teachers with and without specific training, education and career counsellors, psychologists, social workers and pedagogues (ibid.). The main services and bodies offering such support are:

- the secondary schools (lycées) themselves;

- an individual school's Services for Educational Psychology and Guidance (SPOS - Service de psychologie et d'orientation scolaires)

- most schools have one;

- the Centre for Educational Psychology and Guidance, a department at the Ministry of Education, Youth and Childhood (CPOS - Centre de psychologie et d'orientation scolaires); and

- the Centre for Documentation and Information on Higher Education (CEDIES - Centre de Documentation et d'Information sur l'Enseignement Supérieur) (Eurydice, n.d.).

In 2012, several public services and entities merged to form a counselling centre or 'house of guidance' (Maison de l'orientation), bringing together all relevant counselling services for young people and adults like guidance services, educational and psychological support; these services depend on different ministries and are not administratively integrated, but their co-location has significantly increased their cooperation (European Commission, 2013b). Partners of the 'house of guidance' regularly cooperate with schools and provide in-class presentations on the different services and possibilities available to pupils and young people (ibid.). 


\section{Recent relevant reforms}

Luxembourg has been engaged in the process of comprehensively transforming its national education system. The core idea is to make the education system fit better with today's society and to better equip each student to help them succeed in educational vocational and personal life. Reforms are prepared and implemented at all levels of education: reform of VET (2008; for details, see Cedefop, 2015), reform of elementary education (école fondamentale, which includes pre-primary and primary schools, 2009; for the first evaluation, see reports prepared by Université du Luxembourg, 2012 and Koenig, 2013) and the preparatory work for a secondary school reform. The reform of secondary schools was being prepared in 2013 (European Commission, 2013a) and remains at an early stage (European Commission, 2016a). The reforms share some common features: a competence-based approach, early identification of educational difficulties, identification of factors causing educational failure, emphasis on educational and vocational guidance, the cooperation of all stakeholders (Eurydice, n.d.) - namely, attributes also relevant for tackling ESL.

\section{ESL statistics in Luxembourg}

Luxembourg uses both the Eurostat definition of ESLers and a national definition. In national statistics, ESLers are defined as secondary school students of 16 to 24 years who have, during a given school year, left school and did not return before November 15 of the following school year (European Commission/EACEA/Eurydice/Cedefop, 2014). The Eurostat and national statistics on ESL are presented below.

Luxembourg already had relatively low ESL rates at the start of 2000 compared to other EU member states, but still made considerable progress up to 2009 (European Commission, 2011). Since then, slight fluctuations can be observed which to some extent might also be attributed to the small sample size (European Commission, 2016b); the ESL rate stayed below the European headline target of $10 \%$ throughout this period, but attention to the trend in the future is needed. According to the Eurostat (n.d./a) data, Luxemburg's ESL rate was $7.7 \%$ in $2009,6.1 \%$ in $2013,9.3 \%$ in $2015,5.5 \%$ in 2016 (also see Figure 4). The figures on ESL collected at the national level via a centralised digital system by following individual students are usually higher than the figures provided by Eurostat (e.g. see National reform programme, 2016). Moreover, the national data show a steady increase in ESL rates since 2008 from $9.0 \%$ to $13.5 \%$ in $2014 / 15$; the rise is attributed 
to methodological concerns as these constitute theoretical (estimated) ESL rates (MENJE, 2017). At first, Luxemburg set the national target for ESL to below 10\% (European Commission/EACEA/Eurydice, 2013) with the possibility to modify the target in 2015 if the ESL rate had stabilised (European Commission, 2013). Yet the rates in that year were unstable and the national target remained the same (National reform programme, 2016; see LastraBravo, Tolón-Becerra, \& Salinas-Andújar, 2013 for the rationale behind the national targets and possible calculations).

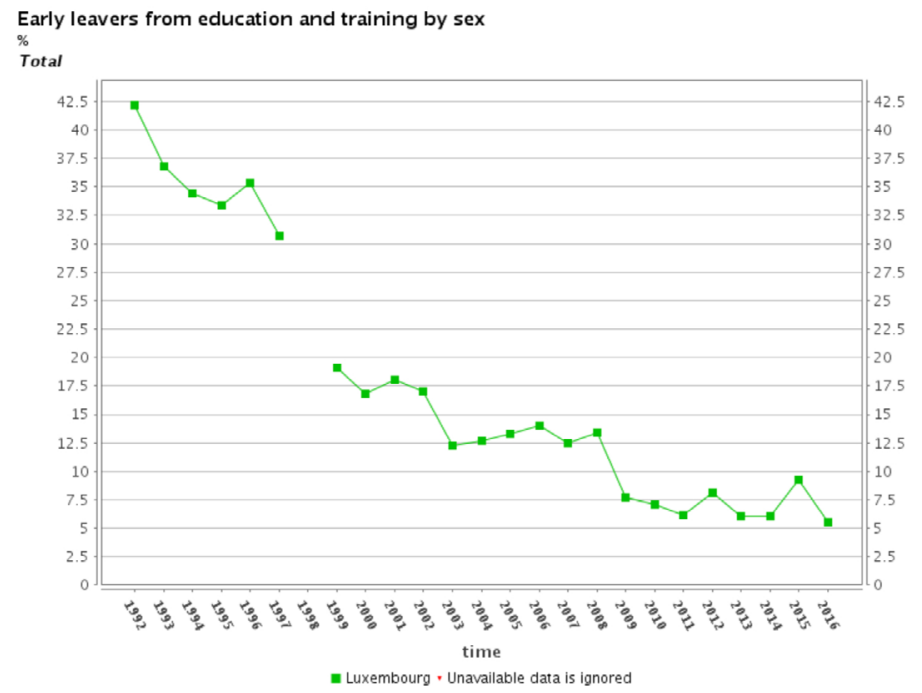

Figure 4. Luxembourg: time trend of share of the population aged I8-24 with at most a lower secondary education and not in further education or training during the last four weeks preceding the survey (Eurostat, n.d./a).

Note. Lower secondary education refers to ISCED (International Standard Classification of Education) 2011 level o-2 for data from 2014 onwards and to ISCED 1997 level o-3C short for data up to 2013 . There is a national-specific time break in the series in $1999,2003,2006,2007,2009,2015$.

The percentage of early leavers is higher for foreign-born versus native-born $(8.1 \%$ versus $5.3 \%$ in $2013,8.5 \%$ versus $4.1 \%$ in 2015$)$ and for male versus female $(8.4 \%$ versus $3.7 \%$ in $2013,6.8 \%$ versus $4.2 \%$ in 2016; Eurostat, n.d./a). National data also reveal a high share of ESLers among students who had at least twice been retained in a grade (MENJE, 2015).

Interestingly, in the 2012/13 school year almost $17 \%$ of the students who left school in Luxembourg decided to re-enrol in a school in one of the 
neighbouring countries (Belgium, Germany or France). The majority of these students $(63 \%)$ commute daily to their school and thus do not need to move to the other country (MENJE, 2015).

\section{Insight into tackling the ESL issue in Luxembourg}

As stated on the website of the Ministry of National Education, Children and Youth, activities and measures to keep students at school have been a priority since 2003 (MENJE, n.d.). Moreover, ESL was recognised as a priority during the Luxembourg Presidency of the EU in 2015; under its presidency, the EU Council's recommendations were adopted as Council conclusions on reducing early school leaving and promoting success in school (Council of the EU, 2015).

In the national context, the ministry responsible for education regularly publishes reports on ESL, including national statistics and other relevant analyses and insights, as well as the results of a survey of actual ESLers (MENFP 2008, 2009, 2011, 2012, 2013; MENJE, 2015, 2017). Several structural reforms, policies and measure(s) have been taken; promotion and support for a cross-sector, multi-disciplinary approach to reducing ESL has been an important feature (Cedefop, 2014; European Commission/ EACEA/Eurydice, 2013) as well as a compensation measure for strengthening second-chance education programmes, particularly those in the area of VET (European Commission/EACEA/Eurydice, 2013). Special emphasis is put on promoting academic success as a way to prevent young people from leaving school and increase young people's qualification levels. Researchers highlight the important need to conceive public health strategies in Luxembourg in the context of tackling ESL (Esch et al., 2011).

Education and career guidance is clearly seen as a prevention, intervention and compensation measure for addressing ESL (European Commission/EACEA/Eurydice/Cedefop, 2014) and, as described in the section on the education system in Luxembourg, is well developed. Some other main activities and measures, including specific pilot projects, are described below (ibid.):

(1) development of policies and projects aimed at identifying groups at risk and providing individual support:

a. early detection procedures within primary education and adjustment measures; 
b. since 2005 'Mosaic Classes' have been provided for students with behavioural difficulties (e.g. failure to comply with internal regulations, systematic absenteeism, aggression, violence etc.) in secondary education (temporary intensive support in small groups targeting the reintegration and re-socialisation of students in their initial class or in a class adapted to their development; MENJE, n.d.; Cedefop, 2015);

c. the 'School Drop-in' pilot project (Plateforme Accrochage Scolaire - PAS; Stoffel, Friedel, \& Thill-Rollinger, 2014) aims to systematically evaluate the risk of ESL amongst students in secondary education (National reform programme, 2016) and implementing measures for students at risk. PAS is coordinated by the CPOS. Its goal is to create educational alliances (see Gilles, Potvin, \& Tièche Christinat, 2012) between different actors and assure the participation of everyone - the PAS team works with the family, the management, the educational team/teachers, the SPOS and the socio-educational team of the high school (lycée) concerned, together with external partners (e.g. socio-medical and psychological services, guidance professionals, employers and others; Stoffel et al., 2014). The purpose is to remobilise the young persons in terms of their personal and academic success, offering them activities that correspond to their social, relational and psycho-emotional needs and difficulties. The PAS team relies on internal resources available within the schools as much as possible and only use external ones when needed (ibid.). It started in 2014/15;

d. the 'Itzigerstee' pilot project for highly problematic students aims to reintegrate students into mainstream education in cooperation with their parents, the school and a psychologist after providing individualised support;

e. workshops organised by Local Youth Action (Action locale pour jeunes - ALJ) for ESLers on motivation, teamwork, the development of vocational projects, internship, and apprenticeship;

f. the 'Stop\&Go' self-development programme organised by CPOS is intended for either students still at school but who have given up on learning, or young ESLers; youngsters work on their personal orientation through various non-verbal means of expression (body expression, photography, theatre) and are provided with an 
opportunity to reflect on the current situation and the path they wish to take personally and academically (MENJE, n.d.);

(2) inclusion of the ESL topic in teacher education: during the 2013/14 school year, three different continuing professional development courses dealing explicitly with demotivation and student dropout were offered to all teachers across the country (Eurydice, 2015); and

(3) development of second-chance schools (Ecole de la ze Chance $\mathrm{E}_{2} \mathrm{C}$ ) that provide both general and vocational training and other support. $\mathrm{E}_{2} \mathrm{C}$ opened in 2011 and offer a regular school programme, but employ a specific pedagogical approach (European Commission, 2013; Cedefop, 2015).

In addition, in Luxembourg a centralised digital student register is maintained to help identify those young people who left school without obtaining a diploma or certification, either during or at the end of the academic year. A monthly report on such young people who have quit school is sent to the Local Youth Action, which contacts these youths individually in order to inquire about the reason for leaving school and to help them enter a training programme (including transfer to another school) or the labour market (European Commission, 2011; 2013b; National reform program, 2016). According to a Local Youth Action survey, the two most common reasons for ESL identified by ESLers were school failure (25\%, including anticipation of a school failure and language problems) and guidance/orientation difficulties ( $25 \%$, e.g. did not like the chosen path, did not have access to the desired path for various reasons, was given poor advice; MENJE, 2015).

Despite all of the measures and actions described above, Luxembourg has no comprehensive strategy in place to tackle ESL (European Commission/EACEA/Eurydice/Cedefop, 2014). In 2015, discussions and reflections on how to draw up a national strategy to keep youth at school started and an observatory for monitoring ESL (Observatoire du maintien scolaire) was announced (National reform programme, 2016). Yet, today a comprehensive ESL strategy, one that addresses all levels of education and training and brings the right mix of prevention, intervention and compensation measures together, is still needed (European Commission, 2016a).

\section{Multi-professional teams}

As mentioned, cross-sectorial cooperation and a multi-disciplinary approach to reducing ESL have been a considerable feature (Cedefop, 2014; 
European Commission/EACEA/Eurydice, 2013) and multi-agency teams working in school may be seen as one form of such approach.

Multi-agency teams at the local/institutional level are well established in Luxembourg's education system (European Commission/EACEA/ Eurydice/Cedefop, 2014). Teams involve school heads, teachers, psychologists, social workers, youth workers and therapists. Every school in secondary education provides a service for educational psychology and guidance (SPOS) which cooperates with teachers, parents, the school's medical service, and with competent services and professional chambers. Multiprofessional teams are also found in the centre of the PAS project (for more information, see above; Stoffel, Friedel, \& Thill-Rollinger, 2014).

Moreover, multi-professional teams (équipes multiprofessonnelles) provide psychological counselling/support - a service for special education (Eurydice, n.d.). In each district in Luxembourg, there is a multi-professional team of experts (psychomotors, psychologists, educators, curative educators...). On the request of the pedagogical team, the multi-professional team supports pupils in difficulty while allowing them to remain in class. The first assessment (Universite du Lux, 2012) revealed the idea of introducing multi-professional teams is generally welcomed (by parents and teachers), but the teams are not seen as well-functioning (yet). Criticism of the use of the multi-professional teams includes the long waiting periods (attributed to the bureaucracy underlying the procedures and the two different bodies responsible for the team members). Another issue is that in many problematic cases the multi-professional teams were not helpful and the advice given to teachers was not concrete (because multi-professional teams work individually with the student or in making the diagnosis). Only exceptionally were teachers informed, instructed or advised how to deal with the student in question. Teachers require recommendations or guidance for their further work. The need for such a team varies greatly in the view of teachers. The results also show that schools perceive it is now more difficult to obtain help (compared to before when the multi-professional teams were introduced in special education) because the professionals offering the support were independent, while now everything is centralised through one institution), although the professionals involved remain more or less the same (ibid.).

To the contrary, there are also excessive requests whereby teachers seek the support of the multi-professional teams; it seems that teachers feel they are not responsible for a student if they are given a 'diagnosis'. It would 
appear that in the future some alignment of what can be done (by the multi-professional teams) and what is expected to be done (by the teaching staff) is needed. A common culture and constructive communication has yet to be established between the various professionals who come from two different sectors (elementary education and special education). Capacity constraints and responsiveness (quick intervention - regular exchange with teaching staff) are important (Universite du Lux, 2012).

\section{Conclusion}

ESL in Luxembourg has received considerable attention since 2000, with the issue also being considered in the country's extensive ongoing reform of its education system. In 2009, Luxembourg achieved the European headline target of $<10 \%$ ESLers and its ESL rate has remained below the target since. Possibly contributing to this progress and providing a good tool in the ESL context is the fact that Luxembourg has a tradition in education and career guidance as well as a multi-agency partnership working in and around schools (e.g. secondary schools provide a service for educational psychology and guidance that cooperates with teachers, parents, the school's medical service, and with competent services and professional chambers). The role of second-chance schools is also promoted. In addition, several other practices and projects have been implemented (e.g. early detection measures, temporary intensive support in small groups for students with behavioural difficulties, providing activities corresponding to the social, relational and psycho-emotional needs and difficulties of students at high risk of ESL, self-development programmes etc.). However, comprehensive national strategy tackling ESL is still missing. In addition, certain characteristics of the education system, such as early tracking with several transitions and high rates of grade retention, may represent risk factors for ESL. Moreover, as highlighted in MENJE (2015), it is clear that in general high schools (lycées) only respond to ESL once it is already obvious; instead, attention to the early causes and pathways is called for, namely at the start of the process that ends in ESL, along with more investment to help prevent ESL.

\section{References}

Cedefop (2014). Early leaving from vocational education and training. Luxembourg. Retrieved from https:/cms-refernet.arianesoft.com/View/ Document/early-leaving-school/en 
Cedefop (2015). Vocational education and training in Luxembourg: Short description. Luxembourg: Publications Office. Cedefop I Series.

Council of the EU (2009). Council conclusions of 12 May 2009 on a strategic framework for European cooperation in education and training ("ET 2020"). Retrieved from http://eur-lex.europa.eu/legal-content/EN/TXT/ $\mathrm{PDF} /$ ?uri=CELEX:52009XG0528(01)\&from $=\mathrm{EN}$

Council of the EU (2015). Council conclusions on reducing early school leaving and promoting success in school (2015/C 417/05). Retrieved from http://eur-lex.europa.eu/legal-content/EN/TXT/ $\mathrm{PDF} /$ ?uri=CELEX:52015XG1215(03)\& from=EN

EACEA/Eurydice study (2011). Grade retention during compulsory education in Europe: Regulations and statistics. Highlights. Brussels, Belgium: EACEA. Retrieved from http://eacea.ec.europa.eu/education/Eurydice/ documents/thematic_reports/126EN_HI.pdf

ELGPN (2014). Lifelong guidance policy development: Glossary. Retrieved from http://www.elgpn.eu/publications/browse-by-language/english/ elgpn-tools-no.-2-llg-glossary/

Esch, P., Bocquet, V., Pull, C., Couffignal, S., Graas, M., Lair, M., ... Ansseau, M. (2011). Psychosocial risk and protective factors of secondary school dropout in Luxembourg: The protocol of an exploratory case-control study. BMC Public Health 11(555), 1-7.

European Commission (2002). Communication from the Commission: European benchmarks in education and training: follow-up to the Lisbon European Council. Retrieved from http://eur-lex.europa.eu/LexUriServ/LexUriServ. do?uri=COM:2002:0629:FIN:EN:PDF

European Commission (2011). Commission staff working paper. Reducing early school leaving. Accompanying document to the proposal for a council recommendation on policies to reduce early school leaving. Retrieved from http://eur-lex.europa.eu/legal-content/EN/TXT/ $\mathrm{PDF} /$ ?uri=CELEX:52011SCoo96\&from $=\mathrm{EN}$

European Commission (2013a). Education and training monitor 2013. Luxembourg. Retrieved from http://ec.europa.eu/dgs/education_culture/ repository/education/tools/docs/etm2013-country-reports_en.pdf

European Commission (2013b). Reducing early school leaving: Key messages and policy support. Final report of the thematic working group on early school leaving. Retrieved from http://ec.europa.eu/dgs/education_culture/repository/education/policy/strategic-framework/doc/ esl-group-report_en.pdf 
European Commission (2016a). Commission staff working document. Country report Luxembourg. Retrieved from http://ec.europa.eu/europe2020/pdf/ csr2016/cr2016_luxembourg_en.pdf

European Commission (2016b). Education and training monitor 2016. Luxembourg. Retrieved from https:/ec.europa.eu/education/sites/ education/files/monitor2016-lu_en.pdf

European Commission/EACEA/Eurydice (2013). Education and training in Europe 2020: Responses from the EU member states. Eurydice Report. Brussels: Eurydice.

European Commission/EACEA/Eurydice (2015). The structure of the European education systems 2015/16: Schematic diagrams. Eurydice Facts and Figures. Luxembourg: Publications Office of the European Union.

European Commission/EACEA/Eurydice/Cedefop (2014). Tackling early leaving from education and training in Europe: Strategies, policies, and measures. Eurydice and Cedefop Report. Luxembourg: Publications Office of the European Union.

European Commission/EACEA/Eurydice/Eurostat (2014). Key data on early childhood education and care in Europe. Eurydice and Eurostat Report. Luxembourg: Publications Office of the European Union.

Eurostat (n.d./a). Early leavers from education and training by sex and country of birth. Retrieved from http://appsso.eurostat.ec.europa.eu/nui/show. do?dataset=edat_lfse_o2\&lang=en

Eurostat (n.d./b) Europe 2020 indicators - education. Retrieved from http://ec.europa.eu/eurostat/statistics-explained/index.php/ Europe_2020_indicators_-_education

Eurydice (2015). Eurydice brief: Tackling early leaving from education and training in Europe. Retrieved from http://eacea.ec.europa.eu/education/eurydice/documents/thematic_reports/183EN.pdf

Eurydice (n.d.). Luxembourg. Accessed 2 December 2015 from https://webgate. ec.europa.eu/fpfis/mwikis/eurydice/index.php/Luxembourg:Overview

Gilles J.-L., Potvin P., \& Tièche Christinat, C. (2012). Les alliances éducatives pour lutter contre le décrochage scolaire. Berne: Peter Lang.

Koenig, S. (2013). La Réforme de l'école fondamentale-Rapport sur le premier bilan. Ministère de l'éducation nationale et de la Formation professionnelle: Luxembourg. Retrieved from http:/www.men.public.lu/ catalogue-publications/fondamental/statistiques-analyses/autres-themes/ reforme-ef/fr.pdf 
Lastra-Bravo, X. B., Tolón-Becerra, A., \& Salinas-Andújar, J. A.(2013). Proposal for national targets in the framework of the European reduction goal for early school leaving. International Review of Education, 59, 569-601.

MENFP (2009). Le décrochage scolaire au Luxembourg: Parcours et caractéristiques des jeunes en rupture scolaire. Causes du décrochage. Année scolaire 2007/2008 [School dropout in Luxembourg: Pathways and characteristics of young people leaving school. Causes of drop-out. School year 2007/2008]. Retrieved from http://www.men.public.lu/catalogue-publications/secondaire/statistiques-analyses/decrochage-scolaire/decrochage-07-08/decr-07-08.pdf

MENFP (2011). Le décrochage scolaire au Luxembourg: Parcours et caractéristiques des jeunes en rupture scolaire. Causes du décrochage. Année scolaire 2008/2009 [School dropout in Luxembourg: Pathways and characteristics of young people leaving school. Causes of drop-out. School year 2008/2009]. Retrieved from http://www.men.public.lu/catalogue-publications/secondaire/statistiques-analyses/decrochage-scolaire/ decrochage-08-09/fr.pdf

MENFP (2012). Le décrochage scolaire au Luxembourg: Parcours et caractéristiques des jeunes en rupture scolaire. Causes du décrochage. Année scolaire 2009/2010 [School dropout in Luxembourg: Pathways and characteristics of young people leaving school. Causes of drop-out. School year 2009/2010]. Retrieved from http://www.men.public.lu/catalogue-publications/secondaire/statistiques-analyses/decrochage-scolaire/ decrochage-09-10/fr.pdf

MENFP (2013). Le décrochage scolaire au Luxembourg: Parcours et caractéristiques des jeunes en rupture scolaire. Causes du décrochage. Année scolaire 2010/2011 [School dropout in Luxembourg: Pathways and characteristics of young people leaving school. Causes of drop-out. School year 2010/2011]. Retrieved from http://www.men.public.lu/catalogue-publications/secondaire/statistiques-analyses/decrochage-scolaire/decrochage-10-11/ fr.pdf

MENFP (Ministère de l'Éducation nationale et de la Formation professionnelle, 2008). Le décrochage scolaire au Luxembourg: Parcours et caractéristiques des jeunes en rupture scolaire. Causes du décrochage. Mai 2006 ŕ avril 2007 [School dropout in Luxembourg: Pathways and characteristics of young people leaving school. Causes of drop-out. May 2006 to April 2007]. Retrieved from http://www.men.public.lu/catalogue-publications/ secondaire/statistiques-analyses/decrochage-scolaire/decrochage-06-07/ decr-06-07.pdf 
MENJE (2015). Le décrochage scolaire au Luxembourg - année scolaire 2012/13 [School dropout in Luxembourg - school year 2012/13]. Retrieved from http://www.men.public.lu/catalogue-publications/secondaire/ statistiques-analyses/decrochage-scolaire/decrochage-12-13/fr.pdf

MENJE (2017). Le décrochage scolaire - année scolaire 2014/15 [School dropout - school year 2014/15]. Retrieved from http://www.men.public.lu/catalogue-publications/secondaire/statistiques-analyses/decrochage-scolaire/ decrochage-14-15/fr.pdf

MENJE (Ministère de l'Éducation nationale, de l'Enfance et de la Jeunesse, 2014). Enseignement fondamental, Cycles 1 à 4, Education différenciée. Année scolaire 2012/13 [Primary education, Cycles 1 to 4, Differentiated education. School year 2012/13]. Luxembourg: MENJE. Retrieved 2 December 2015 from http://www.men.public.lu/catalogue-publications/ fondamental/statistiques-analyses/statistiques-globales/2012-2013/fr.pdf

MENJE (n.d.) Prévention du décrochage scolaire [Prevention of school dropout]. Retrieved from http://www.men.public.lu/fr/actualites/grands-dossiers/enseignement-secondaire-secondaire-technique/prevention-decrochage/index.html

Meyers, R. \& Houssemand, C. (2011). Teachers' perception of school drop-out in Luxembourg. Procedia Social and Behavioral Sciences 15, 1514-1517.

National Reform Programme of the Grand Duchy of Luxembourg under the European Semester (2016). National plan for smart, sustainable and inclusive growth Luxembourg 2020. Retrieved from http://ec.europa.eu/ europe2020/pdf/csr2016/nrp2016_luxembourg_en.pdf

Stoffel, A., Friedel, C., \& Thill-Rollinger, A. (2014). Le projet PAS - plateforme accrochage scolaire [The PAS project: A return-to-school platform]. Paper presented at 2nd Colloque International Du Lasale Sur Le Decrochage Scolaire, 14-16 May, Luxembourg. Retrieved from https://www.hepl.ch/ files/live/sites/systemsite/files/uer-ps/documents/lasale\%2oactes\%2odu\%20 colloque\%202\%2oluxembourg\%202014.pdf

Université du Luxembourg (2012). Rapport d'expertise sur le bilan de la réforme de l'école fondamentale. Ministère de l'éducation nationale et de la Formation professionnelle: Luxembourg. Retrieved 2 December 2015 from http://www.men.public.lu/catalogue-publications/fondamental/statistiques-analyses/autres-themes/expertise-reforme/bilan_reforme_rapport_ unilu.pdf 


\section{I.4 \\ The ESL Situation in Spain}

Maša Vidmar and Manja Veldin

\section{Synopsis}

Spain once had the highest ESL rate among the EU-28 countries, but the rate has fallen considerably in the last few years. Spain is one of very few European countries with a comprehensive strategy in place to reduce ESL. Multi-professional teams are both a legal obligation and a well-established practice.

\section{Summary}

In Spain, ESL was already recognised as a pressing issue back in 1985, although reducing ESL was only acknowledged as a specific objective in an educational law in 2006. Indeed, Spain has a relatively high share of ESLers, one that is constantly above the EU average. According to the latest Eurostat data, the ESL rate in Spain was $19 \%$ in 2016 , higher than the Europe 2020 target of $10 \%$, but has been showing a steady decline in recent years. Spain is currently on the right path to reach the national target of $15 \%$ by 2020 . However, large discrepancies remain between regions, male versus females and native versus foreign-born. Spain is one of very few countries with a comprehensive national strategy to tackle ESL; the strategy's main goal is to reduce factors that lead to ESL and promote the return to education by students who have left education (regardless of whether they are employed or not). Another goal is to conduct special actions in areas with high ESL rates and develop measures and prevention 
programmes for students experiencing difficulties in compulsory education. In addition, some territorial strategies are being implemented by the autonomous regions, while an ongoing reform of the education system is also expected to help lower ESL rates. Spain also has in place education and career guidance in primary and secondary education and numerous other measures (prevention, intervention and compensation strategies) that address the problem. In this context, multi-professional teams operate in schools and are both a legal obligation and a well-established practice.

Key words: Spain, ESL statistics, education, reform, tackling ESL

\section{Introduction}

In Spain, ESL is a well-known problem that is studied by institutions dealing with it and academics from several disciplines (Enguita, Martínez, \& Gómez, 2010). ESL was already recognised as a pressing issue back in 1985, although reducing ESL was only acknowledged as a specific objective in an educational law in 2006. In October 2016, a new government was formed in Spain that made tackling ESL and school failure some of the main objectives as part of its encouragement for the National Pact for Education (Eurydice, n.d.). This aim of the article is to describe the state of affairs and recent trends regarding ESL in Spain. Some characteristics of the Spanish education system relevant to ESL are presented at the beginning (length of compulsory education, transitions, streaming, recent reforms, grade retention etc.), followed by ESL statistics in Spain and some insights into redressing ESL in the country.

\section{Methodology}

We draw information for this article from European documents (European Commission - EC, Eurydice), Eurostat, ministerial documents on ESL and other documents and reports available online (prepared by Spanish local governments or institutions). A search for scientific articles was conducted using the key words "ESL", "ESLer", "drop-out" and "Spain" in the EBSCOhost database. A search was also conducted using the backward procedure. 


\section{Some relevant characteristics of Spain's education system}

The Spanish education system is decentralised. Educational powers are shared between the State General Authority (Ministry of Education, Culture and Sport) and the authorities of the Autonomous Communities (Regional Ministries or Departments for Education). In certain autonomous cities (Ceuta, Melilla), the Ministry of Education alone exercises the educational powers. While the central education administration executes the government's general guidelines on education policy and regulates basic elements of the system, it is the regional education authorities that develop the regional regulations and hold the executive and administrative competencies for managing the education system in their own territory (Eurydice, n.d.).

Education in Spain is compulsory and free in publicly-funded schools for children aged 6 to 16 (Eurydice, 2016). The length of compulsory education was extended (as a prevention measure against ESL) in 2006, from 14 to 16 years of age (Nevala et al., 2011). Several transitions between education levels may pose a risk factor for ESL (e.g. Eccles, 2004). Compulsory education occurs in two stages, primary education (Educación Primaria, 6-12 years of age) that transitions into compulsory secondary education (Educación Secundaria Obligatoria, 12-16 years of age). Streaming begins at the age of 15 (diagnostic test) when students can apply for basic vocational training (Formación Profesional Básica, 15-17 years of age) or successfully complete the compulsory secondary education and continue studying in upper secondary education (Bachillerato, 16-18 years of age) (Eurydice, 2016). They also have Specialised Education (Artistic, Sport and Language education) that has its own organisation (Eurydice, n.d.).

Another important aspect of the education system related to ESL is grade retention (risk factor). Regulations governing grade retention in Spain state that a pupil can only be retained once in their primary education and, if a pupil's grades are not satisfactory, other criteria are taken into account in the final decision on the pupil's progression, and they may be given the opportunity to conditionally progress to the next year (EACEA P9 Eurydice, 2011). According to 2009 PISA data, Spain has one of the highest shares of repeaters at primary school (12.2\%) (EC/EACEA/Eurydice/ Cedefop, 2014). The percentage of students repeating a grade in primary, lower secondary or upper secondary school was $35 \%$, and later dropped to 31.3\% (OECD, 2015). In Spain, it is more likely to repeat a grade at secondary education level than in primary education (Ikeda \& García, 2014). Students 
enrolled at disadvantaged schools (46\%) are more likely to repeat a grade than students at advantaged schools (12\%) (OECD, 2015). Authors (Enguita, Martínez, \& Gómez, 2010) have identified two factors seen among students who drop out: repeating an academic year $(88 \%)$ and absenteeism with unjustified absences (91\%).

In relation to ECEC (a system-level protective factor against ESL), pre-primary education in Spain lasts up to 6 years of age. The second cycle (3-6 years of age) is free of charge but not compulsory and is attended by $96.6 \%$ of 3 -year-olds and up to $99.9 \%$ of 5 -year-olds (EC/EACEA/Eurydice/ Eurostat, 2014), well above the EU average (ET Monitor Spain, 2016b).

\section{Recent relevant reforms}

The Spanish education system has been experiencing reform since the Act on the Improvement of the Quality of Education was passed in 2013 (thus amending the 2006 Education Act). As part of this education system reform, one secondary vocational school programme (PCPI-Programas de Cualificación Profesional Inicial, 16-18 year) was phased out in 2014/15 (Eurydice, 2014). In the future, compulsory secondary education will be organised in cycles ( $1^{\text {st }}$ cycle: $13-15$ years; $2^{\text {nd }}$ cycle: $15-16$ years) and external assessment will be conducted at the end of compulsory secondary education. The assessment will have academic validity, besides the average of the grades that will be weighted when awarding the certificate (Graduado en Educación Secundaria Obligatoria, the first academic certificate obtained after finishing Basic Compulsory Education), which will provide access to Bachillerato, intermediate vocational training, intermediate Plastic Arts and Design Education 'training cycles', Sports Education, and to the world of work. Students not obtaining this certificate will be awarded with another (Certificado oficial de estudios obligatorios), whose aim is to prove their schooling years and the academic competencies achieved therein (Eurydice, n.d.).

\section{ESL statistics in Spain}

In Spain, the national definition of ESL corresponds with Eurostat's: young people aged between 18 and 24 who have not completed upper secondary education and are no longer in education and training (EC/EACEA/Eurydice/ Cedefop, 2014). Spain has a declining trend in the ESL rate. According to Eurostat data (2016), in 2009 the rate stood at $31.2 \%$, having fallen to $23.6 \%$ 
in 2013. Nevertheless, this remained one of the highest ESL rates among the EU-28 and Spain additionally aimed to cut the ESL rate to $23.0 \%$ by 2015 (EC/EACEA/Eurydice/Cedefop, 2014). Spain already achieved this in 2014 when its ESL rate was $21.9 \%$ (EU average 11.1\%) and even more in 2016 when the ESL rate was 19\% (EU average 10.7\%) (Eurostat, 2016). The country's national target for ESL by 2020 is $15 \%$ (10\% in the EU) (EC/EACEA/ Eurydice/Cedefop, 2014). Figure 5 presents Eurostat's ESL rate in Spain for the last 14 years. A noticeable declining trend in the rate can be observed, yet it is constantly above the EU average and there were also a few breaks in the time series (in 2003, 2005, 2006 and 2014), making the data not fully comparable.

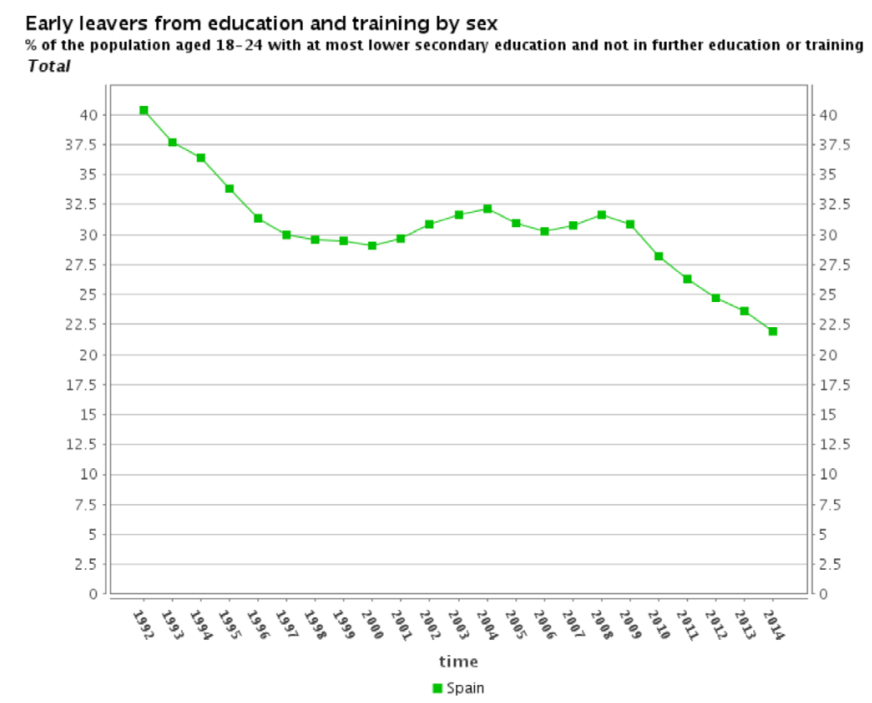

Figure 5. Spain: time trend of share of the population aged I8-24 with at most a lower secondary education and not in further education or training (Eurostat, 2016)

Note: The indicator is defined as the percentage of the population aged $18-24$ with at most lower secondary education and who were not in further education or training during the last 4 weeks preceding the survey. Lower secondary education refers to ISCED (International Standard Classification of Education) 2011 level o-2 for data from 2014 onwards and to ISCED 1997 level o-3C short for data up to 2013. The indicator is based on the EU Labour Force Survey.

The trends in EU-28 countries show that the share of early leavers is higher for foreign-born versus native-born (EU: $19.7 \%$ versus $9.8 \%$ in 2016) and for male versus female (EU: $12.2 \%$ versus $9.2 \%$ in 2016). This is also 
typical for Spain (32.9\% versus $16.1 \%$, and $22.7 \%$ versus $15.1 \%$ ). Foreign-born living in Spain had the highest level of ESL (38.3\%) in EU countries in 2013. According to IVIE (2013), being a female in Spain reduces the probability of ESL by $12 \%$, while being a foreigner increases it by $16 \%$.

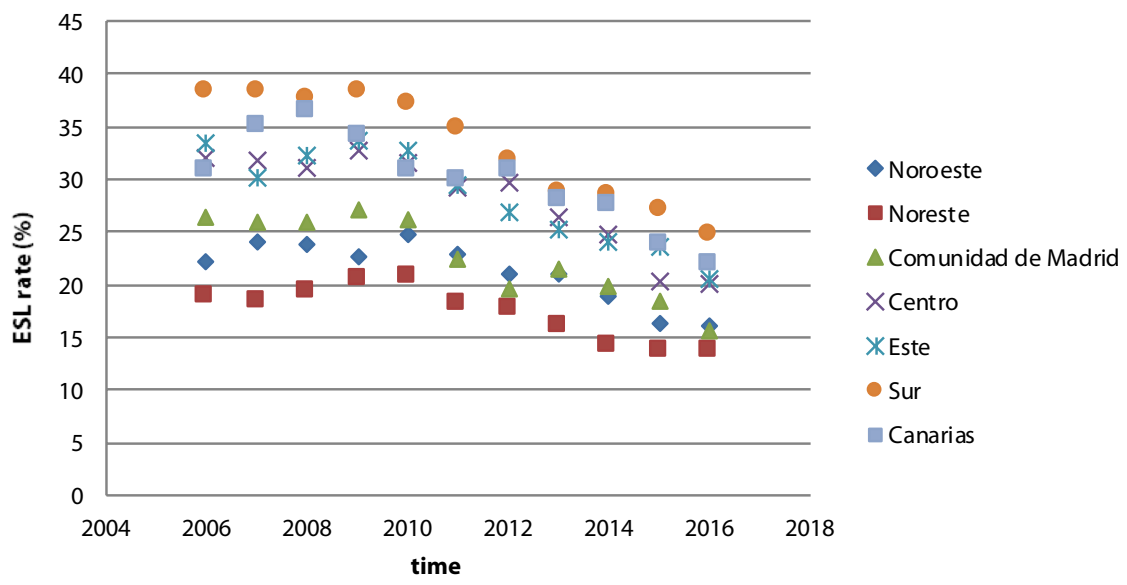

Figure 6. NUTS statistical regions of Spain: time trend of share of the population aged I8-24 with at most a lower secondary education and not in further education or training (Eurostat, 2016)

Note: The indicator is defined as the percentage of the population aged I8-24 with at most lower secondary education and who were not in further education or training during the last four weeks preceding the survey. Lower secondary education refers to ISCED (International Standard Classification of Education) 2011 level o-2 for data from 2014 onwards and to ISCED 1997 level 0-3C short for data up to 2013. The indicator is based on the EU Labour Force Survey.

As we see in Figure 6, Spain also has great regional disparities with the ESL rate in 2016 varying from $12.9 \%$ in Noreste to $23.6 \%$ in Sur (Eurostat database, n.d.). Many northern regions have a high level of investment in education and a heavy industrial profile, encouraging participation in VET. Both lead to less ESL. On the other hand, many southern regions have very different cultural, social and economic conditions that contribute to higher ESL levels (Nevala et al., 2011). A few autonomous communities have ESL levels above $20 \%$, while others have rates lower than the $10 \%$ European average (ET Monitor Spain, 2016b). Disparities in the rate of ESL coincide with indicators showing the income and general economic development of a region (Nevala et al., 2011). While the country is still far from the EU ESL 
target that remains a major challenge in education, gaps in this area were substantially reduced in 2015 and 2016 (EC, 2017).

The ESL rate in Spain increases with age and the educational levels of both parents are relevant (IVIE, 2013). The parents of about $80 \%$ of ESLers in Spain have a low level of education, regarded as one of the biggest factors that influence ESL (Lastra-Bravo, Tolón-Becerra \& Salinas-Andújar, 2013). As Merino and Garcia (2011) state by way of summary of their chapter, factors helping to explain school failure in Spain include the "supply-side" characteristics of individuals and their families, the "demand-side " characteristics of labour markets and the 'institutional' factor, namely what schools are able to and in fact do to increase or reduce ESL. Two authors (Vallejo \& Dooly, 2013) combined the results of studies in Spain that analysed the structural and social causes of the country's high levels of ESL. They present them in two groups; exogenous factors: those affecting the education system but with origins in the social context (socio-economic conditions, ethnic origin, the cultural capital of families, geographical variations in ESL ratios); and endogenous factors: those depending on the educational norms and regulations (subjective evaluation procedures to obtain final certificates, which are set to change under the recent reform, curriculum contents and their relationship to the number of years required for each cycle).

\section{Insight into tackling the ESL issue in Spain}

Reducing ESL was identified as a specific objective in 2006 in the Organic Law on Education (Ley Organica de Educacion, LOE). Called the Organic Act for the Improvement of the Quality of Education (Ley Orgánica para la Mejora de la Calidad Educativa LOMCE), the 2013 version of the document acknowledges the high level of ESL as one of the reform's main drivers (EC/EACEA/Eurydice/Cedefop, 2014). Spain has a clear understanding that tackling ESL requires a partnership approach, which includes the education community in its broader sense (Nevala et al., 2011). The Ministry of Education has created specific units to implement, coordinate and monitor policies regarding ESL (EC, 2013). It is adapting strategies to the varying socio-economic circumstances or the disparities in ESL rates in regions or localities across the country (EC/EACEA/Eurydice/Cedefop, 2014).

In 2008, the Ministry of Education and the Education Administrations of the Autonomous Communities agreed on the "Plan to reduce ESL". It contains a clear framework for policies, projects, proposals and a general 
strategy for tackling ESL (EC/EACEA/Eurydice/Cedefop, 2014). The Plan states the educational authorities should implement special action plans in areas with high ESL rates (identified as those with large immigrant or Roma populations and economically deprived areas) (Nevala et al., 2011). The Plan was followed by the "Programme to reduce ESL in education and training" (Programa para la reducción del abandono temprano de la educación y la formación), put into practice by the Autonomous Communities with the Ministry of Education's collaboration (EC/EACEA/Eurydice/ Cedefop, 2014). Related to the plan and the programme's framework, Spain has taken different actions to tackle ESL, including work on prevention, intervention and compensation measures (EC/EACEA/Eurydice/Cedefop, 2014; Ministerio de Educación, Cultura y Deporte, 2015). The 2013-2016 Strategy for Entrepreneurship and Youth Employment also states that cutting ESL levels is one of its main objectives, which includes giving financial aid to early leavers to return to education (EC/EACEA/Eurydice/Cedefop, 2014). Still, Spain spends less on education at all levels than the EU-27 (in GDP terms) and the differences are much higher in secondary education (it spends $26 \%$ less) than in primary education (5\% less) (Fernández-Macías, Antón, Braña, \& De Bustillo, 2013).

Due to decentralisation, measures may vary in each Autonomous Community, although measures that have proven to be most effective spread quickly and each Community has emphasised measures that address the (educational, social and economic) circumstances with the greatest influence on ESL within their territory (EC/EACEA/Eurydice/Cedefop, 2014). Some progress came when implementing the new educational schemes that aim to increase the quality of primary and secondary education and cut ESL rates in the process. But only limited progress has been recorded in the area of enhancing the guidance given to groups at risk of ESL (EC, 2015).

As a preventive measure, Spain the length of compulsory schooling, reformed the curricula, and implemented new types of study pathways and changes in teaching methods (Nevala et al., 2011). According to ET Monitor (2013), measures to counter ESL at the national and regional level have been put in place in recent years, including the "Plan to fight ESL" (preventive and intervention measures such as analysis, awareness raising, follow up of ESLers to support their reintegration into the education and training system), PROA (a guidance and support programme) and PCPI (an initial professional qualification programme). The Ministry of Education has been 
evaluating these measures. The national programmes referred to above have not been funded by the regions since 2012, and also are not included in the 2013 national budget (ET Monitor Spain, 2013). One of the most significant actions is the assigning of monitoring duties related to ESL actions to the Sectoral Committee for Education (EC/EACEA/Eurydice/Cedefop, 2014).

The Programme for Reinforcement, Guidance and Support - PROA (Programas de Refuerzo, Orientación y Apoyo) has been running since the 2004-2005 academic year and is to be replaced by other measures and initiatives, suggesting a deep structural reform of the education system within the framework of the Law for the Improvement of Quality in Education. PROA aimed to address inequalities in education, prevent social exclusion and give educational establishments extra resources. It worked together with pupils, families and the local environment and provided extra support for individual pupils facing difficulties as well as targeted support for primary and secondary schools hosting large numbers of pupils from socially disadvantaged backgrounds (EC, 2013).

Measurers that offer routes to re-enter the education system are also available in Spain (curricular diversification programmes, PCPI etc.) (EC/ EACEA/Eurydice/Cedefop, 2014). Developments were expected when implementing a 2-year initial vocational training programme that would add flexibility to educational pathways and upgrade the quality of basic VET (EC, 2015). So one of the Spanish plan's recommendations to reduce ESL and reintegrate participants into the education system is to increase enrolment levels in the PCPI, especially in sectors where there are greater employment opportunities. PCPI (Programas de Cualificación Profesional Inicial - Initial Vocational Qualification Programmes) gives students unable to progress at the end of the third year of ESO a choice between repeating the year or pursuing the PCPI which like the traditional Bachillerato leads to a secondary education qualification. It is also an option for young people aged 16 and over who left school early, so it acts like a mechanism helping to bring ESLers into the labour market (Nevala et al., 2011). Only nine regions have so far developed the relevant legislation, leading to far fewer students enrolling than the government expected (EC, 2015).

Education and career guidance are other explicit measures for combatting ESL in Spain. Such measures recognise that guidance plays a central role in improving academic performance and clearly state that one of the objectives of guidance is to provide support and advice to those who left 
education or training early without qualifications (EC/EACEA/Eurydice/ Cedefop, 2014). Some regional administrators have effectively addressed their specific root causes of ESL through local projects and policies, yet there are not many evidence-based analyses available, which hinders national policies' attempts to address the complexity of the problem (ET Monitor Spain, 2016b). Spain has teacher training reforms that directly seek to reduce ESL (Nevala at al., 2011). As a measure to prevent ESL, they give teachers some training in education and career guidance (EC/EACEA/ Eurydice/Cedefop, 2014) and their National Action Plan states that teacher training should aim to raise awareness of the ESL problem (Nevala et al., 2011). The Plan also promotes the practice of competent authorities validating non-formal learning (Nevala et al., 2011).

In Spain, the involvement of different professionals in tackling ESL is well established. The 2006 Organic Law on Education established that the responsibility for cutting ESL is held by all professionals working in schools, and the Programme to Reduce Early School Leaving from Education and Training established specific measures requiring the collaboration of several professionals. There are also well-established multi-agency partnerships within some regional coordinating bodies. Professionals involved at schools and in the community in 2013/14 included school heads, teachers, education and career counsellors, psychologists, social workers and youth workers. Guidance counsellors (orientadores, who must hold a bachelor's degree in pedagogy, psychology or psycho-pedagogy and must also have undertaken an initial education course, or a master's degree), belong to the secondary education body and specialising in educational guidance, are in charge of the guidance given in schools. They provide support, counselling and guidance to students, collaborate with schools and teachers in organising activities, tutoring (for details, see Nouwen, Van Praag, Van Caudenberg, Clycq, \& Timmerman, 2016) and education and career guidance sessions (EC/EACEA/Eurydice/Cedefop, 2014). This education and career guidance structure is a permanent structure of the school and plays a central role in improving academic performances, and preventing and reducing ESL, favouring the students' opportunities for social and labour integration, and transition to adult life. The involvement of all the different professionals within the school and in this structure is both legally compulsory and well-established. Moreover, the abovementioned professionals, together with other professionals (e.g., municipal social workers, members of municipal psycho-pedagogical cabinets, labour counsellors in 
public employment services, staff of non-profit associations etc.) participate in specific measures to reduce ESL, and these measures can take place either within or outside of schools. The measures vary across the different Autonomous Communities and, depending on the specific measure, the professionals are partnered up in different ways, i.e. not all professionals are involved in all measures.

Spain also has specific programmes targeting particularly disadvantaged areas and groups of students (immigrants, ethnic minorities, students with behavioural problems, emotional disorders, lack of motivation etc.) experiencing higher ESL rates. These programmes foster cooperation and coordination with different bodies and local and regional authorities (EC/EACEA/Eurydice/Cedefop, 2014). Some of the decrease in ESL levels can be attributed to the effectiveness of certain regional programmes (EC, 2015). For example, in the Autonomous Community of Galacia the problem was tackled with the "Project to prevent truancy and ESL" that had encouraging results (Nevala et al., 2011). As an example of a reintegration measure, many cities in Spain have established "Second-chance schools" that serve as a transition resource, tend to motivate young people and may be used as a pedagogical resource for addressing other issues before they reintegrate into education or the labour market. A virtual platform allowing distance learning and providing guidance for vocational modules that can lead to qualification was also created (Nevala et al., 2011). The Open Classroom, a curricular adaptation group, is also designed to cope with school failure and prevent ESL (Nouwen, Van Praag, Van Caudenberg, Clycq, \& Timmerman, 2016).

In addition, in collaboration with the Spanish Ministry of Education a well-established and broad Spanish online platform for professional development called Aula Mentor offered a course focusing on ESL (developed within the TITA project). Aula Mentor assists all adults seeking professional development in different areas and certain courses specifically target educators and their professional development; Aula Mentor, n.d.). Educating professionals working in schools on the topic of ESL aims to raise awareness and competencies for ESL prevention and working with (potential) ESLers.

\section{Conclusions}

Spain is one of the few EU member states in which ESL was already recognised as an important issue prior to Europe's attention to ESL within the 
Education \& Training frameworks of 2010 (European Commission, 2002) and 2020 (Council of the EU, 2009). Indeed, ESL rates in Spain are some of the highest in Europe and, despite relative progress made since 2000, the rates remain far above the European target of $10 \%$. Yet Spain reached the national target for 2015 already in 2014 and is thus on the right path to achieve the national target for 2020 of $15 \%$. However, the large discrepancies between regions, males and females, and native and foreign-born remain a challenge.

Spain is also one of the few countries with a comprehensive national strategy in place to tackle ESL which may be translated as the 'Plan to reduce ESL' and the 'Programme to reduce ESL in education and training', with both providing a clear framework for policies, projects, proposals, regional plans, actions and measures. For example, the two documents establish that all professionals working in schools are responsible for preventing ESL and require the collaboration of different professionals. The involvement of various professionals in multi-professional teams within the school and the education and career guidance structures is thus legally compulsory and well-established. Moreover, the school structure has further links with professionals from other institutions (inter-agency partnerships). Hence, while several actions and recommendations for cutting ESL levels exists in Spain, the need remains to increase investment in education and national research on ESL, better acknowledge and manage diversity as an intrinsic trait of quality education, make school timetables more flexible so as to allow part-time jobs and smaller class ratios to enable more personalised attention etc. (for details, see Vallejo \& Dooly, 2013). To conclude, despite the long way Spain has come in tackling ESL, it is necessary to continue the efforts and focus to ensure further progress.

\section{References}

European Commission (2002). Communication from the Commission: European benchmarks in education and training: Follow-up to the Lisbon European Council. Retrieved from http://eur-lex.europa.eu/LexUriServ/LexUriServ. do?uri=COM:2002:0629:FIN:EN:PDF

Council of the EU (2009). Council conclusions of 12 May 2009 on a strategic framework for European cooperation in education and training ("ET 2020"). Retrieved from http://eur-lex.europa.eu/legal-content/EN/TXT/ $\mathrm{PDF} /$ ?uri=CELEX:52009XG0528(01)\&from=EN 
EACEA P9 Eurydice (2011). Grade retention during compulsory education in Europe: Regulations and statistics. Retrieved from http://eacea.ec.europa. eu/education/eurydice/documents/thematic_reports/126EN.pdf

EC (European Commission) (2013). Reducing early school leaving: Key messages and policy support. Retrieved from http://ec.europa.eu/dgs/education_culture/repository/education/policy/strategic-framework/doc/ esl-group-report_en.pdf

EC (European Commission). (2013). Education and training monitor 2013. Spain. Retrieved from http://www.prodetur.es/prodetur/AlfrescoFileTran sferServlet?action=download\&ref=251e3o66-72bb-44co-8420-54f5e $782 \mathrm{e} 342$

EC (European Commission). (2015). Macroeconomic imbalances. Country Report - Spain 2015. Retrieved from http://ec.europa.eu/economy_finance/ publications/occasional_paper/2015/pdf/ocp216_en.pdf

EC (European Commission) (2016a). Country Report - Spain 2016. Retrieved from http://ec.europa.eu/europe2020/pdf/csr2016/cr2016_spain_en.pdf

EC (European Commission) (2016b). Education and training monitor 2016. Spain. Retrieved from https:/ec.europa.eu/education/sites/education/files/ monitor2016-es_en.pdf

EC (European Commission) (2017). Country report Spain 2017. Retrieved from https://ec.europa.eu/info/sites/info/files/2017-european-semester-country-report-spain-en.pdf

Eccles, J. S. (2004). Schools, academic motivation, and stage-environment fit. In R. Lerner, \& L. Steinberg (Eds), Handbook of Adolescent Psychology (2nd ed., pp. 125-153). Hoboken, NJ: John Wiley \& Sons.

EC/EACEA/Eurydice/Cedefop. (2014). Tackling Early Leaving from Education and Training in Europe: Strategies, Policies, and Measures. Eurydice and Cedefop Report. Luxembourg: Publications Office of the European Union.

EC/EACEA/Eurydice/Eurostat. (2014). Key Data on Early Childhood Education and Care in Europe. 2014 Edition. Eurydice and Eurostat Report. Luxembourg: Publications Office of the European Union.

Enguita, M. F., Martínez, L. M., \& Gómez, J. R. (2010). School failure and dropouts in Spain. Social S Collection. 29. Retrieved from https://multimedia2.caixabank.es/lacaixa/ondemand/obrasocial/pdf/estudiossociales/ vol29_en.pdf

Eurydice. (2014). The structure of the European education systems 2014/15: Schematic diagrams. Retrieved from http:/eacea.ec.europa.eu/education/ eurydice/documents/facts_and_figures/education_structures_EN.pdf 
Eurydice. (2016). The structure of the European education systems 2016/17: Schematic diagrams. Retrieved from https:/webgate.ec.europa.eu/fpfis/ mwikis/eurydice/images/9/9d/Structure_of_education_systems_2016_17. pdf

Eurydice. (n.d.). Countries - description of national education systems. Retrieved from https://webgate.ec.europa.eu/fpfis/mwikis/eurydice/index. php/Spain:Overview

Eurostat. (2016). Early leavers from education and training by sex. Spain. Graph. Retrieved from http://ec.europa.eu/eurostat/tgm/table. do?tab=table\&init $=1 \&$ plugin $=1 \&$ pcode $=$ tsdsc410\&language $=$ en

Eurostat database. (n.d.) Retrieved from http://ec.europa.eu/eurostat/data/ database

Fernández-Macías, E., Antón, J.-I., Braña, F.-J. \& De Bustillo, R. M. (2013). Early school-leaving in Spain: evolution, intensity and determinants. European Journal of Education, 48(1): 150-164.

Ikeda, M., \& García, E. (2014). Grade repetition. OECD Journal: Economic Studies, 2013(1), 269-315. Retrieved from http://www.oecd-ilibrary.org/ economics/grade-repetition_eco_studies-2013-5k3w65mx3hnx

IVIE. (2013). El abandono educativo temprano: Análisis del caso español [Early school leaving: Analysis of the Spanish case]. Retrieved from http://www. mecd.gob.es/dctm/inee/documentos-de-trabajo/abandono-educativo-temprano.pdf?documentId=0901e72b8173034a

Lastra-Bravo, X. B., Tolón-Becerra, A., \& Salinas-Andújar, J. A. (2013). Proposal for national targets in the framework of the European reduction goal for early school leaving. International Review of Education, 59(5), 569-601.

Merino, R., \& Garcia, M. (2011). School dropout and completion in Spain. In School Dropout and Completion (pp. 99-115). Springer Netherlands.

Ministerio de Educación, Cultura y Deporte [Ministry of Education, Culture and Sport]. (2015). Plan para la reducción del abandono educativo temprano [Plan to reduce early school leaving in early education]. Retrieved from http://www.mecd.gob.es/dms/mecd/educacion-mecd/mc/aprendealolargodelavida/plan-red-abandono.pdf

Nevala, A., Hawley, J., Stokes, D., Slater, K., Otero, M. S., Santos, R., Duchemin, C., \& Manoudi, A. (2011). Reducing early school leaving in the EU. Retrieved from http://ec.europa.eu/social/BlobServlet?docId=9591\&langId=en

Nouwen, W., Van Praag, L., Van Caudenberg, R., Clycq, N., \& Timmerman, C. (2016). School-based prevention and intervention measures and alternative 
learning approaches to reduce early school leaving. Retrieved from http:// www.diva-portal.org/smash/get/diva2:1046840/FULLTEXTo1.pdf

OECD. (2016). PISA 2015 Results (Volume II): Policies and practices for successful schools. Retrieved from http://dx.doi.org/10.1787/9789264267510-en

Vallejo, C. \& Dooly, M. (2013). Early school leavers and social disadvantage in Spain: From books to bricks and vice-versa. European Journal of Education, 48(3), 390-404. doi:10.1111/ejed.12037 



\section{I.5}

\section{The ESL Situation in Switzerland}

Manja Veldin and Maša Vidmar

\section{Synopsis}

Switzerland does not provide an official definition of ESLers, although the rate reported by Eurostat is low. The issue of ESL is typically embedded in the context of national programmes and initiatives tackling poverty, risk groups, employability etc. This approach importantly contributes to success in preventing and tackling ESL. Multi-agency partnerships at the local/institutional level are well established.

\section{Summary}

Since Switzerland is not an EU member state it officially does not follow the Europe 2020 targets nor has it set any national quantitative target in this area. However, in one national education document the objective is stated as $95 \%$ of the population aged below 25 years being an upper secondary graduate (EDI/EVD/EDK, 2011). According to Eurostat data, in 2016 Switzerland's ESL rate was 4.8\%. It has been decreasing in the last 7 years and has always been below the Europe 2020 target ESL rate of $10 \%$. However, large discrepancies between the ESL rate among foreign-born and native-born remain. Even though Switzerland does not have a comprehensive strategy to tackle ESL, the Swiss Conference of Cantonal Ministers of Education (EDK) plays a leading role in addressing ESL. Typically, 
ESL is not addressed as a separate or specific issue, but given attention in the context of tackling poverty, supporting students from risk groups, providing attractive VET, providing quality career education and guidance, providing time out of school for students, giving guidelines on how to support the personal, emotional, and social development of students (e.g. a national programme to tackle poverty, temporary and alternative optional courses, the Inter-institutional Cooperation programme, Time-out, VET Case Management etc.). Moreover, Switzerland features strong multi-sectoral involvement and cooperation. Multi-agency partnerships at the local and/or institutional level are well established (not dealing specifically with ESL; including teachers, school heads, guidance specialists, psychologists, social workers etc.). In this context, the value of educational alliances is recognised. Vocational education and training holds a very high status in Switzerland so most young people enrol in it, also helping to deliver high rates of overall completion. Yet this remains a challenge in the context of large social inequalities in programme participation and access to university and the professions.

Key words: Switzerland, ESL statistics, VET, multi-professional partnership

\section{Introduction}

The Swiss education system is characterised by multilingualism (Eurydice, n.d.), federalism and decentralisation based on the principle of subsidiarity (Pagnossin, 2011). There are four different languages of instruction (German, French, Italian or Romansh) with the language depending on the region. In the decentralised education system, the main responsibility for education lies within the 26 Cantons (states), which are fully responsible for compulsory education and share responsibilities with the Federal Government for post-compulsory education (including general education schools, vocational and professional education and training (VET) and universities). There is no free choice of school in compulsory education and 95\% of all children attend public schools in their local municipality that are free of charge. There is no national curriculum so each Canton is responsible for the curriculum and obliged by the Federal Constitution to coordinate and harmonise its education system regarding the structure and objectives. Decentralisation of the system is also reflected in the fact that the 
Cantons and their municipalities finance the majority of public expenditure on education (90\%) (Eurydice, n.d.).

In relation to the ESL issue, the situation is somewhat specific because Switzerland is not a member of the EU so it does not follow the Europe 2020 targets. Thus, ESL as a separate and specific topic has received considerably less attention than in EU member states. Yet in Switzerland ESL is embedded in the wider context of tackling poverty, risk groups, employability etc. The aim of this article is to describe the state of affairs and current trends regarding ESL in Switzerland, to shed light on the context in which experiments within the TITA project take place, thus guiding the interpretation and generalisation of the findings. At the beginning, we present some characteristics of the Swiss education system relevant to ESL (compulsory education, transitions, grade-retention options, education and career guidance etc.), followed by statistics on the level of ESL in Switzerland and ways of dealing with ESL (usually in the broader context of addressing other issues and not specifically ESL).

\section{Methodology}

We draw information for this article from documents and reports available online (prepared by Switzerland's local governments or institutions), European documents, Eurostat, ministerial documents on ESL and others. A search for scientific articles was conducted using the key words "Switzerland", "Swiss", "ESL", "ESLer" and "drop-out' in the EBSCOhost database, resulting in very few hits. A search was also conducted using the backward procedure.

\section{Some relevant characteristics of Swiss education system}

Education in Switzerland is compulsory between the ages of 4 and 15 in most cantons (in a few at age 5 or 6; EC/EACEA/Eurydice/Eurostat, 2014). This period includes three transitions: from 2 years in kindergarten or preschool (Kindergarten / école enfantine / scuola dell'infanzia, 4-6 years) to 6 years in primary school (Primarschule / école primaire / scuola elementare, 6-12 years) and 3 years at lower secondary level (Sekundarstufe I / secondaire I / scuola media, 12-15 years) (Eurydice, 2016). The division of years on various levels varies in some cantons (Eurydice, n.d.). At lower secondary level there is also 1 year in Gymnasiale Maturitätsshuln / écoles de maturité 
/ scuole di maturità that lasts from 14-15 years of age, and changes into upper secondary level at 15 years of age and lasts up to 18/19 years of age.

At upper secondary level one can also find Brückenangebote / offres transitoire / formazioni transitorie (15-16 years of age), and Fachmittelschulen / écoles de culture génerale / scuole specializzate (15-18 years of age) that transit into Fachmaturität / maturité spécialisée / maturità specializzata (18-19 years of age) and one of the vocational programmes Berufsmaturität / maturité professionnelle - maturità professionale (15-20 years of age) (Eurydice, 2016). There are various ECEC facilities and services (Kindertagesstätten / crèches / nidi d'infanzia - daycare centres; and Tagesfamilien / familles de jour / famiglie diurne) for which there is no legal entitlement to place a child in if under the age of four (Eurydice, n.d.) while the last 2 years of pre-primary education are compulsory (EC/EACEA/ Eurydice/Eurostat, 2014). However, in 2011 Switzerland only had $78.7 \%$ of children between the age 4 and the start of compulsory primary education enrolled in ECEC (ibid.). In 19 cantons (out of 26), attendance in pre-primary education is compulsory and lasts 1 or 2 years, depending on the canton. Where pre-primary education is not compulsory, children from the age of 4 and 5 are legally entitled to a publicly subsidised place (ibid.).

Tracking begins in lower secondary education, where teaching is realised at different performance levels (Eurydice, n.d.). Students are separated at the end of primary school into different schools and programmes based on interest, aptitudes and formal selection (Lamb, 2011). For most children (structures are not the same across the cantons), selection (made on teachers' decisions that are mainly based on school marks) starts at the lower secondary level, when they are 11-12 years old, according to the requirements of the track in which they are allowed to enrol (Pagnossin, 2011). The upper secondary level is divided into a vocational track and an academic track. Vocational education is either provided by full-time vocational schools or is organised in the so-called Dual System as apprenticeship programmes (that combine school-based education and work-based learning) (Forsblom, Negrini, Gurtner \& Schumann, 2016). Pupils can skip or repeat a year; both measures depend on a pupil's development status and performance (Wolter et al., 2014). According to the OECD's 2012 PISA data, the proportion of students in Switzerland reporting they had repeated a grade in primary, lower secondary or upper secondary school is around $20 \%$ (EC/ EACEA/Eurydice/Cedefop, 2014). 
Switzerland does not provide career education and guidance in primary education (EC/EACEA/Eurydice/Cedefop, 2014). In lower secondary general education, it is a compulsory part of the curriculum and provided in the classroom (mostly by teachers without specific training and rarely by those specially trained for guidance) and every canton is free to decide on how such guidance is delivered. In upper secondary general education, career guidance and education is only provided by specialist external guidance services, which have a permanent office in most schools of French-speaking Switzerland. Recent reforms have reinforced and organised career education and guidance in secondary lower education by including it in more specific modules instead of teaching it as a cross-curricular topic only (ibid.).

\section{ESL statistics in Switzerland}

There is no official definition of ESL in Switzerland (EC/EACEA/Eurydice/ Cedefop, 2014). However, in the 2011 Common Education Policy objectives for the Swiss Education Area (Taking optimal advantage of opportunities - Chancen optimal nutzen/Valor sation optimale des chances), the concept used is "early leavers from education and training", which applies to students who leave school without having completed upper secondary education (EDI/EVD/EDK, 2011). In contrast to the Eurostat definition (ESLer refers to someone aged 18 to 24 who has completed at most lower secondary education and is not involved in further education or training (Eurostat, n.d.)), in Switzerland persons without an upper secondary qualification and only studying in non-formal education are also called early leavers (EC/EACEA/Eurydice/Cedefop, 2014).

According to Eurostat data, Switzerland's ESL rate in 2016 was $4.8 \%$ and has been decreasing in the last 7 years (it was 9.1\% in 2009) (see Figure 7). There is no significant difference in the shares of male and female ESLers (8.8\% male and $9.4 \%$ female in $2009 ; 4.6 \%$ male and $4.9 \%$ female in 2016 ) (Eurostat, 2017b). As such, Switzerland is one of the few countries in which the difference in gender rates is less than 1.o percentage point (EC/EACEA/ Eurydice/Cedefop, 2014) and, despite this small difference, also one of the few countries where the percentage of ESLers is higher in the female population.

As Figure 7 shows, the rate has always been below the Europe 2020 target of 10\% (at least since 1996). Although Switzerland does not follow the Europe 2020 targets and therefore does not set any national quantitative 
target within this framework, its objective is set at $95 \%$ of upper secondary graduates among the population aged below 25 years (European Commission/EACEA/Eurydice/Cedefop, 2014) in the national document (“Chancen optimal nutzen"; EDI/EVD/EDK, 2011). In 2005, the proportion of young Swiss who obtained a qualification at the end of post-compulsory education was $89 \%$ (Pagnossin, 2011).

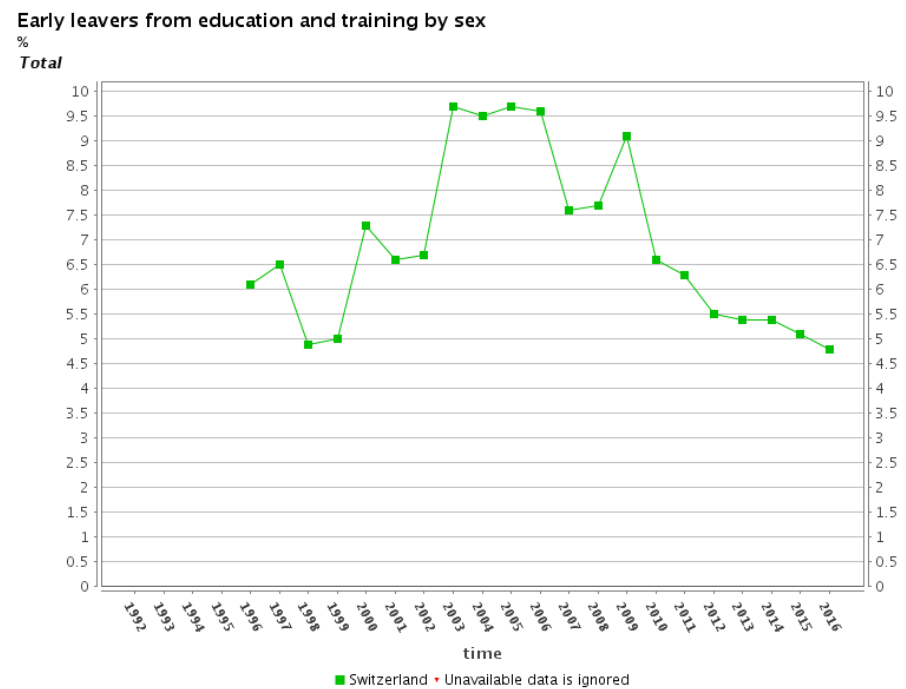

Figure 7. Switzerland: time trend of share of the population aged I8-24 with at most a lower secondary education and not in further education or training (Eurostat, 2017a).

Note: The indicator is defined as the percentage of the population aged $18-24$ with at most a lower secondary education and who were not in further education or training during the last four weeks preceding the survey. Lower secondary education refers to ISCED (International Standard Classification of Education) 2011 level o-2 for data from 2014 onwards and to ISCED 1997 level o-3C short for data up to 2013. The indicator is based on the EU Labour Force Survey. In 2003 and 2014, Switzerland changed its methodology.

As a noticeable trend in the EU-28, the share of ESLers is higher for foreign-born versus native-born in Switzerland (in 2016: EU 19.7\% versus 9.8\% and in Switzerland $\mathbf{1 2 . 2 \%}$ versus 3.2\%) for the last 10 years (Eurostat, n.d.). The main factors determining difficulties for children while making transitions relate to their SES and immigrant background (Stamm et al., 2009; in PPMI, 2014). Switzerland has one of the highest rates of children with a foreign background (children with foreign citizenship or foreign-born children) (EC/EACEA/Eurydice/Eurostat, 2014). However, it is 
important to distinguish the ethnic origin of different minority students; for instance, Tamil students in Switzerland are the most engaged group of immigrant students at school and therefore the least at risk of school dropout (Makarova \& Herzog, 2013).

\section{Insight into tackling the ESL issue in Switzerland}

ESL and ESLers are not officially defined in Switzerland nor is the issue comprehensively addressed at the national level (there is no comprehensive strategy to tackle ESL) - at least not as a separate issue (EC/ EACEA/Eurydice/Cedefop, 2014). There is no official coordinating body in Switzerland, but in practice the Swiss Conference of Cantonal Ministers of Education (EDK) plays the pivotal role in addressing ESL (ibid.). Some authors state that in Switzerland policies contain an explicit requirement to reduce ESL (Juhász, 2015). Moreover, the issue is addressed in the context of tackling poverty, dealing with risk groups, and increasing employability. Some of these initiatives and programmes are presented below.

Since 2010, the Confederation and the cantons have been jointly monitoring the Swiss education system. The Confederation, cantons and communities aim to reduce institutional barriers between levels of government through the political platform Tripartite Agglomerationskonferenz / Conférence tripartite sur les agglomérations (TAK/CTA) that has published several recommendations for the education area, of which some are also relevant to tackling ESL. The confederation launched the National programme to tackle poverty (Nationales Programm zur Bekämpfung von Armut/programme national de lutte contre la Pauvreté) that also focuses on areas touching on ESL (ECEC; support for students to and during VET; second-chance education). There is also a focus on statistical data that should help better identify groups at risk (of ESL). Specific targeted measures for groups at risk focus on students who are socially disadvantaged, have a migrant background or special educational needs (EC/EACEA/ Eurydice/Cedefop, 2014). Moreover, they have structures called MATAS temporary and alternative optional courses. These are "parentheses" structures, meaning they entail a transition and aim to reintegrate young people into the mainstream system. They belong to a study path, by teaching the principle of compensation they readjust the youth to academic standards so that they return to the school system (Thibert, 2013).

Multi-sectoral involvement and cooperation on the governmental level - both horizontal (different sectors) and vertical (central, regional, local 
levels) - are essential for addressing ESL and the Inter-institutional cooperation programme (Interinstitutionelle Zusammenarbeit / Collaboration interinstitutionnelle - IIZ/CII) is a form of such cooperation. It is a tool used to help re-integrate people into the education system or labour market. It aims to develop inter-institutional cooperation and define formal and informal models of collaboration between institutions that are active in different fields (social affairs, education, employment, health etc.). For instance, in the canton of Valais, which is participating in the TITA project, inter-institutional cooperation has been developed among local employment offices, social assistance offices, invalidity insurance, centres for vocational guidance, regional medical services, accident insurance and centres for drug addiction (Duell, Tergeist, Bazant, \& Cimper, 2010). Switzerland has a clear requirement in its policies to reduce early leaving, which sees mechanisms being put in place to monitor and evaluate the effectiveness of the cooperation between the parties involved in tackling early leaving. The policy areas of education and employment enjoy a tradition of cooperation; youth, social affairs, family and justice also cooperate within projects. Multi-agency partnerships at the local/institutional level are well established and include teachers, school heads, guidance specialists, psychologists, social workers, youth workers, speech and language specialists (EC/ EACEA/Eurydice/Cedefop, 2014). There are individualising structures: small classes, available teachers, unexpected changes in activity, different curricula, therapists and external people, who aim to restore the individual (taking their needs into account) and to restore teaching (with a range of people stepping in and various subjects). Resorting to alternative teaching is frequent (cooperative, differentiated, individualised, active etc.). These structures are based on educational alliances (teachers of different subjects, guidance advisors, therapists, special needs teachers, vocational and social tutors, educators, psychologists etc.), but do not mention partnership with the outside world much, except for parents and training schools or companies (Tièche-Christinat et al., 2012; in Thibert, 2013). Allenbach (2014) examined educational alliances in Switzerland by interviewing professionals already involved in such collaborative practices (specialist teachers, psychologists, nurses, meditators, speech therapists and psycho-moto therapists). He concluded that the concept of alliance is crucial for understanding certain subtle and delicate dimensions of the collaborative work and to identify the conditions needed for such practice to develop. 
Compensation national measures, so-called Time-out interventions, are being implemented in ever more cantons (having started in 2001). Students are excluded from school for up to three months to attend projects that provide them with educational and pastoral support from craftsmen, social workers and/or special educators. The aim of these projects is to reintegrate young people back into school, either their existing school or a new one (Kendall and Kinder, 2005). Two guidebooks called "Clés pour l'adolescence" (Keys for teens) and "Clés pour l'action" (Keys for taking steps) that were published in Switzerland tested tools for preventing ESL aimed at students, teachers and parents. These guides allow students and teachers to work on self-confidence, the classroom climate, communication and active listening. As a tool of personal development for youth, it is mostly used when they move from primary to secondary school and it also intends to attract parents to school (Thibert, 2013).

Career education and guidance is explicitly considered as a prevention, intervention and compensation measure for tackling ESL (EC/EACEA/ Eurydice/Cedefop, 2014). Each canton in Switzerland has its own regulations on career education and guidance. Guidance is reinforced during the transition from lower to upper secondary education or at the end of compulsory education to encourage and motivate education beyond the compulsory stage. Accordingly, the early tracking and streaming of students into different educational paths takes place at the end of primary education, making supporting transitions by providing guidance quite critical in the Swiss education system. As a rule, this guidance includes close collaboration with external specialised centres for vocational and career guidance. (ibid.). Bauer and Riphahn (2006) examined cantonal variations in the age of tracking in interaction with parental education and showed that late tracking reduces the relative advantage of privileged children.

In Switzerland, the vocational route has a high status and is fully integrated with specific enterprises, whereby the close links between the training provider and the enterprise help to retain more young people. One key factor identified for helping young people to find appropriate opportunities to stay in education and training is the variety of vocational schools, intermediate and technical vocational schools, pre-vocational schools, transition and access courses leading to apprentice training (Kendall \& Kinder, 2005). At the end of compulsory education, the majority (more than $70 \%$ ) of Swiss young people attend vocational training (Pagnossin, 2011). Thus, only a minority of students (around 20\%) pursue academic studies while the 
majority pursue and complete technical training or vocational qualifications, helping to deliver high rates of overall completion. While high rates are achieved, this occurs in the context of large social inequalities in programme participation and access to university and the professions (Lamb, 2011). Switzerland has a wide range of measures for improving the quality and attractiveness of its VET programmes. The VET Case Management programme is a specific measure, a national project (2008-2015) legally backed in the federal law on VET and implemented in all cantons. It identifies vulnerable young people at an early stage and supports them in a coordinated and structured way. Specialists help them enter VET during their education and/or when they should enter the labour market. This project is an example of IIZ coordination that demands a multi-agency approach (education, social affairs and employment (EC/EACEA/Eurydice/ Cedefop, 2014). The transitional programmes provide a pathway for young people who cannot obtain an apprenticeship due to conditions in the job market and the lack of opportunities provided by employers. For twothirds to three-quarters of young people in this situation, this results in them going back to school or getting an apprenticeship (Polesel, Nizińska \& Kurantowicz, 2011). Motivation Semesters is a labour market programme specially designed for unemployed young people. It offers them a fixed sixmonth structure that allows them to choose their vocational pathways. In the federal law on VET there is also an option for adults that gives them a second chance to attain a VET certificate (EC/EACEA/Eurydice/Cedefop, 2014).

\section{Conclusions}

Although that Switzerland is not an EU member state and is not included in the Europe 2020 framework and the issue of ESL has a relatively low profile in the national context, a more in-depth insight shows that ESL and related phenomena are actually being considered. The fact there is a national education document (EDI/EVD/EDK, 2011) which establishes the objective of $95 \%$ of the population aged below 25 years being an upper secondary graduate is indicative. ESL is typically not addressed as a separate or specific issue, but given attention in the context of tackling poverty, supporting students from risk groups, providing attractive VET, giving quality career education and guidance, providing time out of school for students, establishing guidelines on how to the support personal, emotional and social development of students. Moreover, multi-agency partnerships at the local/ 
school level (not dealing specifically with ESL) and the value of educational alliances are seen as important.

\section{References}

Allenbach, M. (2014). Faire alliance: un métier? Défis et paradoxes des intervenants à l'école [Making the alliance: A profession? Challenges and paradoxes of school actors]. Paper presented at $2^{\text {nd }}$ Colloque International $\mathrm{Du}$ Lasale Sur Le Decrochage Scolaire, 14-16 May, Luxembourg. Retrieved from https://www.hepl.ch/files/live/sites/systemsite/files/uer-ps/documents/ lasale\%2oactes\%2odu\%2ocolloque\%202\%2oluxembourg\%202014.pdf

Bauer, P. \& Riphahn, R.T. (2006). Timing of school tracking as a determinant of intergenerational transmission of education. Economics Letters, 91(1), 90-97.

EC/EACEA/Eurydice/Cedefop (2014). Tackling Early Leaving from Education and Training in Europe: Strategies, Policies, and Measures. Eurydice and Cedefop Report. Luxembourg: Publications Office of the European Union.

EC/EACEA/Eurydice/Eurostat (2014). Key Data on Early Childhood Education and Care in Europe. 2014 Edition. Eurydice and Eurostat Report. Luxembourg: Publications Office of the European Union.

EDI/EVD/EDK (Eidgenössisches Departement des Innern/Eidgenössisches Volkswirtschaftsdepartement/Schweizerische Konferenz der kantonalen Erziehungsdirektoren). (2011). Chancen optimal nutzen. Erklärung 2011 zu den gemeinsamen bildungspolitischen Zielen für den Bildungsraum Schweiz. Retrieved from https://edudoc.ch/record/96061/files/erklaerung_30052011_d.pdf

Eurostat (2017a). Early leavers from education and training by sex. Switzerland. Graph. Retrieved from http://ec.europa.eu/eurostat/tgm/table.do? tab $=$ table\&init $=1 \&$ plugin $=1 \&$ pcode $=$ tsdsc 410 \&language $=e n$

Eurostat (2017b). Early leavers from education and training by sex. Switzerland. Table. Retrieved from http://ec.europa.eu/eurostat/tgm/table. do?tab=table\&init $=1 \&$ plugin $=1 \&$ pcode $=$ tsdsc 410 \&language $=$ en

Eurostat (2017c) Early leavers from education and training by sex and country of birth. Switzerland. Table. Retrieved from http://appsso.eurostat.ec.europa.eu/nui/submitViewTableAction.do

Eurostat database (n.d.) Retrieved from http://ec.europa.eu/eurostat/data/ database 
Eurydice (2016). The structure of the European education systems 2016/17: Schematic diagrams. Retrieved from https:/webgate.ec.europa.eu/fpfis/ mwikis/eurydice/images/9/9d/Structure_of_education_systems_2016_17. pdf

Eurydice (n.d.). Countries - description of national education systems. Retrieved from https://webgate.ec.europa.eu/fpfis/mwikis/eurydice/index. php/Countries

Duell, N., Tergeist, P., Bazant, U. \& Cimper, S. (2010). Activation Policies in Switzerland, OECD Social Employment and Migration Working Papers. Retrieved from http://www.oecd.org/els/listofsocialemploymentandmigrationworkingpapers.htm

Forsblom, L., Negrini, L., Gurtner, J., \& Schumann, S. (2016). Dropouts in Swiss vocational education and the effect of training companies' trainee selection methods. Journal of Vocational Education \& Training, 68(4), 399-415.

Juhász, J. (2015). Final report on Crocoos: Cross-sectoral cooperation focused solutions for the prevention of early school leaving project background research. Retrieved from http://www.cpi.si/files/cpi/userfiles/projektno-sodelovanje/ Crocoos/FinalResearchReportCroCooS.pdf

Kendall, S. \& Kinder, K. (2005). Reclaiming those disengaged from education and learning: A European perspective. NFER National Foundation for Educational Research.

Lamb, S. (2011). School dropout and inequality. In Lamb, S., Markussen, E., Teese, R., Sandberg, N. \& Polesel, J. (Eds.), School Dropout and Completion. International Comparative Studies in Theory and Policy (pp. 369-390). New York: Springer.

Makarova, E. \& Herzog, W. (2013). Hidden school dropout among immigrant students: A cross-sectional study. Intercultural Education, 24(6) 559-572.

Pagnossin, E. (2011). School dropout and completion in Switzerland. In Lamb, S., Markussen, E., Teese, R., Sandberg, N. \& Polesel, J. (Eds.), School Dropout and Completion. International Comparative Studies in Theory and Policy (pp. 191-211). New York: Springer.

Polesel, J., Nizińska, A., \& Kurantowicz, E. (2011). Pathways to completion for school dropouts. In Lamb, S., Markussen, E., Teese, R., Sandberg, N. \& Polesel, J. (Eds.), School Dropout and Completion. International Comparative Studies in Theory and Policy (pp. 357-367). New York: Springer.

PPMI (Public Policy and Management Institute). (2014). Study on the effective use of early childhood education and care in preventing early school 
leaving. Annex 1. Literature review. Luxembourg: Publications Office of the European Union.

Thibert, R. (2013). Early school leaving: Different ways to deal with it. Dossier d'actualité Veille et Analyses IFÉ, 84. Lyon: ENS de Lyon. Retrieved from http://ife.ens-lyon.fr/vst/DA-Veille/84-may-2013_EN.pdf

Wolter, S.C., Cattaneo, M.A., Denzler, S., Diem, A., Grossenbacher, S., Hof, S. et al. (2014). Swiss Education Report 2014. Aarau: Swiss Coordination Centre for Research in Education. Retrieved from http://skbf-csre.ch/fileadmin/files/pdf/bildungsmonitoring/Swiss_Education_Report_2014.pdf 

2.I.6

\section{ESL in the EU: Learning from Differences and Common Trends}

Urška Štremfel

\section{Synopsis}

The differences in policies and practices for addressing ESL in the EU should be seen as creating a lucky situation since through the process of policy learning they enable various unique solutions to be found to the ESL problem. Despite the well-established architecture for policy learning, the vertical transfer of knowledge between the various levels of multi-level governance remains a challenge.

\section{Summary}

EU cooperation in the area of education is non-binding and works on a voluntary basis. This means there is no single (formal) policy on ESL (e.g. Alexiadou, 2007). Consequently, very unique ways for achieving the shared goal (of reducing the average EU rate of ESLers to below $10 \%$ by 2020) are being developed at the member-state level (taking their institutional and cultural background into account etc.). According to policy learning theory (e.g. Radaelli, 2003), these differences should be regarded as fortuitous because they enable (good) practices to be shared, thereby increasing the likelihood of finding characteristics that are common in different national/regional/local/institutional specific solutions. An important approach to identifying such (good) practices entails the policy experimentations conducted within the TITA project. This paper systematically 
presents the biggest theoretical considerations of policy learning theory via the questions 'Who learns?', 'How do they learn?', 'What do they learn?', 'Why do they learn?', 'With what effect do they learn?' and provides some concrete examples of policy learning within the European educational space and the TITA project. The paper shows that various individual, collective, state and non-state actors are involved in more and less institutionalised forms of policy learning. It points out that benchmarking charts (showing differences and common trends in tackling ESL in the EU) require an in-depth contextualisation so as to become a valuable source for policy (and not merely social and policy learning). In order to justify the main motives for policy learning (to find a solution to ESL in the EU and follow a commonly agreed goal), the results of the local TITA experiments (in France, Luxembourg and Switzerland) must not only be appropriately contextualised, but also horizontally and vertically transferred to and across the EU.

Key words: EU, ESL, policy learning, policy experimentation

\section{Introduction}

Eurostat (2017) reports that since 2000 ESL in the EU has been stably decreasing and approaching the agreed target (10\% of ESLers in 2020). Yet, greater insight reveals that, despite this common trend, differences among member states remain large not only in the shares of ESL (e.g. 19\% in Spain, 4.9\% in Slovenia in 2016), but also in the approaches (policies and practices) used to tackle it. Another explanation of these big differences is that EU cooperation in the area of education (including ESL) is based on the open method of coordination (OMC), a specific, non-binding form of cooperation that does not require national laws to be harmonised, and thus enables very unique national responses to be developed for a widely recognised problem and for common EU goals to be achieved in the field. In this environment, differences should be seen as a lucky situation and a precondition for policy learning (Radaelli, 2003). ${ }^{\mathrm{I}}$ The emergence of policy learning as a

1 Diversity leads to greater opportunities for mutual learning by creating a richer stock of experiences to draw on when devising new policies. The development of new policy innovations is not explicitly part of this institutional long-term capability of the whole system for generating policy innovations. If a successful OMC in a particular policy field implies that all member states have imitated the "best policy" that was identified, this may lead to the convergence or even harmonisation of policies in member states, thereby limiting the possibilities for policy learning (Kerber \& Eckardt, 2007). 
central mode of governance ${ }^{2}$ has been explained and justified from various perspectives (Gornitzka, 2006; Hartlapp, 2009; Kan, 2005; Radaelli, 2008), while policy learning in official EU documents is also presented as a key component of EU governance (e.g. Council of the EU, 2009; 2015).

Table 2. Definition of policy learning.

\begin{tabular}{ll}
\hline Policy learning presents the process in which ... \\
Who? & Numerous interested individual and collective policy actors \\
& in a more or less institutionalised manner \\
& on a voluntary or coercive basis \\
& with various motives and strategies \\
& taking into consideration the complexity of public policies and institutional \\
& framework/context \\
How? & on the basis of their own experiences, from others or with others \\
& form, give and/or take \\
& rationally and/or socially and/or politically constructed knowledge \\
What? & in order to control uncertainty, \\
& identify and solve policy problems, \\
& set an agenda, \\
develop alternative solutions, & monitor implementation and evaluate public policies \\
Why? & and thereby achieve individual and/or collective rational and/or consensual \\
& and by doing this change the ideas, values, interests, instruments, goals, pro- \\
& grammes and institutional structure or (some) actors involved.
\end{tabular}

Source: Fink Hafner et al. (2OI2).

Radaelli (2008) defines policy learning as a potential mechanism for deliberative collective problem-solving since it encourages member states and other actors to exchange information, draw comparisons and evaluate existing practices. A closer look at the existing literature reveals there is no uniform definition of policy learning and that several different classifications of policy learning exist, mainly varying in terms of who the actors are that provide the source of the knowledge exchange (Etheredge \& Short, 1983; Hemerijck \& Visser, 2003; Grin \& Loeber, 2007; Hartlapp, 2009; Gilardi, 2010); the types of policy transfer (Dolowitz \& Marsh, 1996) and the type of changes brought about by it (Argyris \& Schön, 1978; Hall, 1993; Olsen \& Peters, 1996; Eising, 2002). All of these discussions and classifications may be summarised in the following questions: 'Who learns?',

2 In the article, we understand governance as both a structure and a process as part of which a multitude of actors solve policy problems in order to achieve common goals (Pierre \& Peters, 2000). 
'What do they learn?' and 'With what effect do they learn?' which, as part of classifying the original policy learning theories, were asked by Bennet and Howlett (1992)3. Fink Hafner et al. (2012) supplemented these questions with two additional ones: 'How do they learn?' and 'Why do they learn?'. As evident from Table 1 below, these questions provided the basis for a definition that attempts to encompass all of the diverse forms of policy learning, while simultaneously also enabling any exclusionary or partial definitions to be used for explaining policy learning in a specific context. We argue this broad definition (aggregation of various forms and academic definitions of policy learning) presented in Table 1 can in addition provide a valuable framework for understanding policy learning processes in the EU in the area of tackling ESL.

The aim of this article is to present, based on an in-depth review of existing literature and practical examples, how ESL policies at the EU level are formed, implemented and evaluated within the policy learning framework. The article shows that policy learning in the EU context is not just a set of various different activities but is organised in a well-thought-out policy learning architecture. ${ }^{4}$ These insights are not only scientifically relevant but also practically useful for relevant and other interested actors to understand and exploit the various policy learning opportunities available in the field. Policy learning has a stronger impact if actors consciously enter the policy learning process and are aware of its potential.

After introducing the topic (EU framework for addressing ESL) in policy learning theory, the article systematically elaborates the topic by asking 'Who learns?', 'How do they learn?', 'What do they learn?', 'Why do they learn?', and 'With what effect do they learn?'. For each question, answers are provided through a theoretical review and highlighted with specific examples from ESL policy in the EU and some practical insights from the TITA project (marked in italics).

3 A closer look at the existing literature also reveals that all subsequent definitions and classifications (e.g. Dolowitz \& Marsh, 1996; Grin \& Loeber, 2007; Zito \& Schout, 2009) are based on the original definitions and are interwoven. Dunlop and Radaelli (2010) came across 16 different interwoven types (definitions) of learning.

4 This article complements the brief introduction to policy learning found in the article "2.1.1 Understanding ESL in the EU: Policy overview and development" with its in-depth theoretical considerations and some practical insights from the TITA project. 


\section{Methods}

To address the article's aims, we employ the following methods: (a) an analysis of relevant literature and secondary sources. In this framework, we conducted a literature search of the scientific EBSCOhost and Web of Science online research databases. The main key words used in the search for relevant scientific literature were: early school leaving, education, EU, policy learning, policy borrowing, policy lending, peer learning, lesson drawing;' (b) an analysis of formal documents and legal sources at the EU and national levels (EU official documents in the field of educational policy, non-official documents, press releases etc. Policy documents taken into account had to meet the following criterion: to have been published between 2000 and 2017.

\section{Who learns?}

Authors (e.g. Larionova, 2007; Radaelli, 2004) explain that in its ideal-typical and most abstract form, policy learning in the area of education in the EU takes place between institutions found at multiple levels, and runs in at least four directions:

- $\quad$ EU-level learning within communities of policymakers engaged in EU policy processes (or "learning at the top");

- hierarchical learning from the EU level down to the domestic and local level (or "learning from the top");

- "learning from below" (i.e. social actors, regions, local governments) to the top (or "bottom-up learning"); and

- horizontal learning (learning between the member states, or regions).

Policy learning is a social process, meaning that individual policy actors have to had acquired knowledge somewhere (from either other individual actors or within organisations, networks and communities labelled as collective actors) (Holzinger \& Knill, 2005). As seen in its ideal form,

5 Steiner-Khamsi (2012) explains that although policy learning, policy borrowing and policy lending indicate the same processes, the term policy learning is more frequently used in policy studies while the terms policy borrowing and lending are more significant for comparative education. Since the paper chiefly originates from policy studies, the term policy learning is used in the paper. 
policy learning in the EU involves various state and non-state actors ${ }^{6}$ who rely on variable partnership forms, which is also congruent with the Lisbon Strategy architecture (European Council, 2000, para 38).

May (1992) believes there is a gap between normative assumptions (who is supposed to learn) and behaviourist assumptions (who actually learns). Early assessment of policy learning in the EU in the area of education policies painted quite a disappointing picture. For example, empirical evidence (Radaelli, 2004) indicated that it was especially learning at the top (or EU-level learning) among a highly professionalised technocratic elite that was significant, there was embryonic evidence of cognitive convergence from the top, and almost no evidence of learning from below ("bottom-up learning" or "social learning"). Another deficiency of describing policy learning in a multi-level context was that insufficient attention was placed on the flow between all three levels (EU, national, regional). Structures to ensure the multi-level coordination of actors were indispensable and in practice the learning process occurring between them was often interrupted for various reasons (e.g. weak institutionalisation).

More than a decade later, it seems that the first quite disappointing evidence has become more positive. An important contribution to this is the new E\&T 2020 framework and especially the Erasmus+ projects within Key action 3 devoted to providing support for policy reform, which the TITA project also forms part of. They provide a well-thought-out framework for the formation, implementation and evaluation of local policy experimentations ${ }^{7}$. Based on the contextualisation of their results, specific policy recommendations are prepared for the EU level. E.g. in the TITA project framework, local multi-professional teams for addressing ESL have been experimented with in France, Luxembourg and Switzerland. The TITA project thus represents a well-considered balance between top-down, bottom-up and horizontal learning approaches, with the involvement and close cooperation of various state and non-state actors from all levels of multi-level governance. Although the local experiments' effectiveness has

6 Stone (1999) is convinced that most policy learning takes place among state actors as this is the prerequisite for policy learning as opposed to mere learning.

7 In addition to EU policy experimentation, some EU member states have a well-developed national system of social experimentation. In France, as part of the government strategy for sustaining local programmes for educational completion, "Fond d'Expérimentation pour la Jeunesse" are established as a tool for promoting social experimentation and establishing links between different levels of government (Berthet \& Simon, 2012). A review of the existing social experiments in France shows that several of them deal with ESL. 
been evaluated through a strictly prescribed protocol (see EACEA, 2015), their actual exploitation at the EU level and dissemination in the form of mainstream practice across the EU remains open and calls for monitoring and evaluation over a longer period of time once the project formally ends.

\section{How do they learn?}

\section{In a more or less institutionalised manner}

Policy learning is most likely to take place when a suitable institutional infrastructure is in place (absence of any uniform or rigid rules, enabling sufficient informal communication and knowledge exchange). It should include a set of policy instruments that build up the participating actors' institutional learning capability (Stone, 1999; Gornitzka, 2006; Radaelli, 2008).

\section{On a voluntary or coercive basis}

Dolowitz and Marsh (1996) distinguish three policy transfer types: 1) voluntary transfer, which occurs when policymakers decide on the policy transfer on their own and on a voluntary basis due to their dissatisfaction with the existing national policy; 2) direct imposition of the transfer, which occurs when one actor forces another to adopt a certain policy; and 3) indirect imposition of the transfer, which is based on certain (extrinsic) factors or a functional dependence, that encourages actors to transfer a policy voluntarily.

\section{With various motives and strategies}

While some accept new knowledge and lessons for purely symbolic or strategic reasons to muster political support, others apply the new knowledge and lessons to actually make changes and improve their understanding of policy problems and the current situation. It is widely believed that policy learning is more common during a period of failure and crisis, when actors have a stronger desire and need to change and improve the current situation (Levitt \& March, 1988; Hemerijck \& Visser, 2001, 7; Radaelli, 2004).

\section{Taking the complexity of public policies and the institutional context into consideration}

Some authors (e.g. Rose, 2002; Hsueh, 2009) point out that superficial imitation alone is far from sufficient to successfully transfer ideas, policies 
and practices from one institutional framework to another environment. Here it is necessary to understand and consider the complexity of public policies, as well as the varying institutional contexts entailed. In circumstances of increasing complexity, it is thus essential to: a) recognise one's own policy problem; b) decide where to look for a solution; c) research how a certain policy and practice work in another institutional framework; d) develop a causal model of the way the policy and practice work in that institutional framework; e) (re)formulate lessons for the transfer of the policy and practice into one's own institutional context; f) decide whether in fact to transfer the policy and practice; g) provide suitable sources for the policy and practice to be implemented; h) look at any additional special risk that might arise when adopting the lesson in one's own institutional context; i) reduce the special risk by conducting a prior evaluation; and $\mathrm{j}$ ) apply others' (positive or negative) lessons in one's own context. These phases are widely recognised as 10 steps to follow in seeking to learn lessons from abroad.

\section{On the basis of their own experiences, from others or with others} Hemerijck and Visser (2003), Radaelli (2004), Volden et al. (2008), Hartlapp (2009) identify three different types of learning:

a) Learning from one's experiences, which helps actors prevent or reduce future mistakes. Reducing mistakes provides a motivational basis for looking at one's own institutional and organisational past and thus for learning based on monitoring and evaluating one's own systems.

b) Learning from others, which occurs when actors use information about the consequences of political decisions in other countries, without them being affected themselves.

c) Learning with others, which includes consultations, experimentation, exchange and the collection of information and experience in pursuing shared goals.

\section{They form, give and/or take}

Actors within policy learning are never simply passive recipients of the newly acquired knowledge. They can suitably contextualise the newly acquired knowledge and use it to alter their conviction (Dunlop \& Radaelli, 2010). Based on the premises of policy (Heclo, 1972), imperialistic and coercive 
learning (Lange \& Alexiadou, 2010), the dominant actors in policy learning processes are those who attempt to impose their convictions, policies and practices on other actors (in)directly. In doing so, they assume the role of a teacher, whereas other actors who accept the convictions, policies and practices may be seen as learners. Accordingly, the question should not only be 'Who learns?' but 'Who teaches?' (Grek, 2009).

The TITA project is a clear example of institutionalised, voluntary policy learning with the aim to find a solution to ESL. Irrespective of whether its results will provide a policy learning example of failure or success, learning from its experiences (in the French, Luxembourgish and Swiss Francophonic local contexts) will require in-depth contextualisation. Research (e.g. Jugović \& Doolan, 2013) shows that not only specific local contexts but also specific EU regions can share some similarities regarding ESL, which distinguish them from other parts of the EU. By learning lessons from the TITA experiences, Rose (2002) steps for learning lessons from abroad, presented above, could be taken into consideration.

\section{What do they learn?}

No standard definition of knowledge in terms of what is supposed to constitute the core of policy learning can be found in the literature. Knowledge (as a subject of policy learning) can (regardless of whether it refers to new policy instruments, frameworks or paradigms) be formulated rationally (the positivist approach to understanding knowledge dominates here) ${ }^{8}$ or socially ${ }^{9}$ and politically ${ }^{\text {10 }}$ (where the constructivist approach dominates).

Taking research findings showing that tackling ESL in the EU is not only policy but also political exercise (e.g. Macedo, Araújo, Magalhães \& Rocha, 2015) into consideration, how we understand benchmarking charts, which reveal differences and common trends in EU anti-ESL efforts, is important. A quick and superficial overview of them may lead to an impression about which are good and bad education systems/practices worth learning from. These are facts which can easily trigger social and political

8 Scientifically obtained data are intended for developing, validating and improving the beliefs of key actors and, as such, motivate actors to achieve goals (Sabatier, 1993). norms and the discourse structure defining good policy and steering individuals' actions (Checkel, 1999; Gilardi \& Radaelli, 2012; Hall, 1993). 
learning. Making benchmarking charts a reliable source for policy learning calls for their in-depth contextualisation. Well-developed national information systems for gathering information on ESLers are a precondition for this. They (should) not only consist of comparable statistical data but also other (qualitative and quantitative) information that helps to understand the phenomenon in detail (e.g. Thematic Working Group, n.d.). Hordosy (2014) reports that the big differences in national information systems (e.g. student registers, national or regional surveys) have so far allowed little room for making comparisons across Europe. Given that "first experiences in countries applying more advanced data collection systems show that high-quality monitoring is very useful in maximising the reduction in ESL" (European Commission, 2016), these could provide an unexploited source of more in-depth policy learning and an even more positive trend of reducing it at the EU level.

\section{Why do they learn?}

Policy learning helps in controlling uncertainty by enabling changes to be understood and to thereby construct scenarios and predictions in an ever changing environment. In terms of the factors that catalyse policy learning and explain why policy learning occurs in the first place, two sets of factors can be identified: a) factors at the individual level, which include looking for solutions to policy problems, controlling uncertainty, achieving individual and collective goals and searching for the truth; b) structural factors, which include time-related factors that stimulate policy learning (an election period, economic crisis, regime transformation, a period of lack of success, a period of uncertainty), political culture, the institutional structure of a country, special characteristics of public policy and organisational competence (e.g. Bennet \& Howlett, 1992).

The motives for policy learning in the form of policy experimentation for dealing with ESL within the TITA project can be explained by the great complexity of the ESL policy problem and the consequences it holds for individuals, nation states and EU society as a whole, along with the already established infrastructure for multi-professional cooperation in participating countries (France, Luxembourg, Switzerland). Experiences of the leading partner (France) with social experimentations in the ESL field clearly also represent an important factor explaining the EU's interest in policy learning in the TITA setting. 


\section{With what effect do they learn?}

Certain authors (e.g. Stone, 1999; Radaelli, 2008; Hartlapp, 2009; Gilardi, 2012) believe it is extremely difficult to explain the reasons for policy learning, mainly due to the difficulties in causality and the fact that several factors may trigger policy learning. These connections become all the more complicated when seeking to explain policy changes as the key consequences of policy learning. In relation to this, a big divide is seen in the literature in answers to the question of whether a policy change is a prerequisite for policy learning. While some authors (Sabatier, 1993; Grin \& Van de Graaf, 1996; Pemberton, 2003) argue it is only possible to talk about policy learning when it results in a policy change, others (Dolowitz \& Marsh, 1996; Hemerijck \& Visser, 2001; 2003; Lange \& Alexiadou, 2010) believe a policy change is not a prerequisite for the policy learning process. Hartlapp (2009) adds that policy learning, per se, is not a goal, but is aimed at the implementation of political programmes and achieving of policy goals. When policy learning is regarded as learning that brings about policy changes, this encompasses a change in ideas, values, interests, instruments, goals, programmes and the institutional structure of (some of) the actors involved (Rose, 2005; Dolowitz \& Marsh 2000). It can also provide the preconditions for ideational convergence, that is, the convergence of policymakers around a set of criteria that define good policy.

At least the following intended changes should be brought about by the TITA project: a) ideas and values concerning how ESL is understood and should be resolved; b) instruments for solving the problem (from sectoral to cross-sectoral collaboration); c) an institutional structure in terms of establishing local multi-professional teams for addressing ESL across the EU. The precondition that policy learning within the TITA project in the form of policy experimentation will actually bring any substantial changes in educational policies and practices at the EU level and across the EU is that internal and external actors show interest and engagement. Follow-up activities for monitoring and evaluating its long-term impact are also necessary. According to Vilpišauskas (2011), a decade would be an appropriate time frame for such a review.

\section{Conclusion}

This article shows that the EU's policy framework on ESL establishes a unique architecture for policy learning that is not simply limited to topdown learning (»listening recommendations « from EU institutions), but 
encompasses a wide variety of bottom-up learning (local experimentation) and bottom-bottom learning (comparing lessons from among the states involved). The article reveals that this is also the case within the TITA project.

The question of whether TITA is just a 3-year policy experiment (learning) or will actually trigger any policy change (at local, regional, national or EU level) remains unanswered. Given the broadness of policy learning theory, lessons will in any case be learnt: how (not) to implement multi-sectoral approaches to ESL. It is currently still uncertain how they will be transferred to wider (EU and member states) environments. Considerable further effort at all levels is needed to ensure that the local experiments do not remain strictly local, completely experimental and limited in time and funding (Berthet \& Simon, 2012).

\section{References}

Alexiadou, N. (2007). The Europeanisation of education policy - changing governance and "new modes of coordination «. Research in Comparative and International Education, 2(2), 102-116.

Argyris, C. \& Schön, D. A. (1978). Organizational learning: A theory of action perspective. New York: McGraw-Hill.

Bennett J. C. \& Howlett, M. (1992). The lessons of learning: Reconciling theories of policy learning and policy change. Policy Sciences, 25(3), 275-294.

Berthet, T. \& Simon, V. (2012). Regional policies and individual capabilities: Drawing lessons from two experimental programs fighting early school leaving in France. Social Work \& Society, 1o(1), 1-19.

Birkland, A. T. (2005). An introduction to the policy process: Theories, concepts, and models of public policy making. New York: M.E. Sharpe.

Checkel, T. J. (1999). Social construction and integration. Journal of European Public Policy, 6(4), 545-560.

Council of the EU. (2009). Council conclusions of 12 May 2009 on a strategic framework for European cooperation in education and training ('ET 2020'). Retrieved from http://eur-lex.europa.eu/legal-content/EN/TXT/ $\mathrm{PDF} /$ ?uri=CELEX:52009XG0528(o1)\&from=EN

Council of the EU. (2015). Council conclusions on reducing early school leaving and promoting success in school. Retrieved from http://eur-lex.europa.eu/ legal-content/EN/TXT/PDF/?uri=CELEX:52015XG1215(o3)\&from=EN

Dolowitz, P. D. \& Marsh, D. (1996). Who learns what from whom: A review of the policy transfer literature. Political Studies, 44(2), 343-357. 
Dolowitz, P. D. \& Marsh, D. (2000). Learning from abroad: The role of policy transfer in contemporary policy-making. Governance, 13(1), 5-24.

Dunlop, A. C. \& Radaelli, C. M. (2010). Systematizing policy learning. Paper presented at American Political Science Association Annual Meeting, 2-5 September, Washington, USA.

EACEA (2015). Guidelines for planning and conducting a European policy experimentation project involving field trials. Retrieved from https://eacea. ec.europa.eu/sites/eacea-site/files/annex_i_to_the_guidelines.pdf.

Eising, R. (2002). Policy learning in embedded negotiations: Explaining EU electricity liberalization. International Organization, 56(1), 85-120.

Etheredge, S. L. \& Short, J. (1983). Thinking about government learning. Journal of Management Studies, 2o(1), 41-58.

European Commission (2016). European Semester Thematic Fiche. Early Leavers from Education and Training. Retrieved from https://ec.europa. eu/esf/transnationality/filedepot_download/.../1047.

European Council. (2000). Presidency Conclusions. Lisbon European Council. 23 and 24 March 200o. Retrieved from http://www.europarl.europa.eu/ summits/lis1_en.htm.

Eurostat (2017). Early leavers from education and training. Retrieved from http://ec.europa.eu/eurostat/web/products-datasets/-/tesemo2o.

Fink Hafner, D., Deželan, T., Knep, M., Kustec Lipicer, S., Lajh, D. \& Štremfel, U. (2012). Definicija javnopolitičnega učenja. Rezultat temeljnega raziskovalnega projekta Javne agencije za raziskovalno dejavnost Republike Slovenije »Odprta metoda koordinacije: analiza njenih javnopolitičnih (policy) in političnih posledic« (J5-2030), 1. 5. 2009-30. 4. 2012. Ljubljana: Center za politološke raziskave.

Gilardi, F. (2010). Who learns from what in policy diffusion processes? American Journal of Political Science, 54(3), 650-666.

Gilardi, F. (2012). Transnational diffusion: Norms, ideas and policies. In W. Carlsnaes, T. Risse \& B. Simmons (Eds.) Handbook of International Relations, Second edition, (pp. 453-477). Thousand Oaks: Sage.

Gilardi, F. \& Radaelli, C. M. (2012). Governance and learning. In D. Levi-Faur (ed.), The Oxford Handbook of Governance (pp. 155-168). Oxford: Oxford University Press.

Gornitzka, A. (2006). The Open Method of Coordination as practice - A watershed in European education policy? Oslo: University of Oslo, Arena Working Paper, No. 16/2006. 
Grek, S. (2009). Governing by numbers: The PISA “effect” in Europe. Journal of Education Policy, 24(1), 23-37.

Grin, J. \& van de Graaf, H. (1996). Implementation as communicative action. An interpretative understanding of interactions between policy actors and target groups. Policy Sciences, 29(4), 291-319.

Grin, J. \& Loeber, A. (2007). Theories of policy learning: Agency, structure and change. In F. Fischer, G. J. Handbook of Policy Analysis: Theory, Politics, and Methods, (eds.), Frank Fischer, Gerald J. Miller and Mara S. Sidney (pp. 581-604). Boca Raton, London, New York: Taylor and Francis.

Hall, A. P. (1993). Policy paradigms, social learning, and the state: The case of economic policy-making in Britain. Comparative Politics, 25(3), 275-296.

Hartlapp, M. (2009). Learning about policy learning. Reflections on the European Employment Strategy. European Integration online Papers, 13(1): 1-16.

Heclo, H. H. (1972). Review Article: Policy Analysis. British Journal of Political Science, 2(1): 83-108.

Hemerijck, A. \& Visser, J. (2001). Learning and mimicking: How European welfare states reform. Amsterdam: University of Amsterdam, Working Paper.

Hemerijck, A. \& Visser, J. (2003). Policy learning in European welfare states. Amsterdam: University of Amsterdam, Working Paper.

Holzinger, K. \& Knill, C. (2005). Causes and conditions of cross-national policy convergence. Journal of European Public Policy, 12(5), 775-796.

Hordosy, R. (2014). Who knows what school leavers and graduates are doing? Comparing information systems within Europe. Comparative Education, $50(4), 448-473$.

Hsueh, L. (2009). Policy ideas, learning, and international institutions. Paper presented at Midwest Political Science Association Annual Conference, 2-5 April, Chicago, USA.

Jugović, I. \& Doolan, K. (2013). Is there anything specific about early school leaving in Southeast Europe? A review of research and policy. European Journal of Education, 48(3), 363-377.

Kan, H. (2005). Opening the black box: Developing a framework to analyse process of cross-national learning. Paper presented at Young Researchers Workshop of The European Network for Social Policy Analysis (ESPAnet), University of Bath, 1 and 2 April, Bath, Great Britain. 
Kerber, W. \& Eckardt, M. (2007). Policy learning in Europe: The open method of co-ordination and laboratory federalism. Journal of European Public Policy, 14(2), 227-247.

Lange, B. \& Alexiadou, N. (2010). Policy learning and governance of education policy in the EU. Journal of Education Policy, 25(4), 443-463.

Larionova, M. (2007). EU Education Policy Development Tools and the Open Method of Coordination »Advancing the European Education Agenda . Retrieved from http://www.educationpolicy.eu/papers/index.php/ educationagenda/brussels-leuven2oo7/paper/viewFile/20/10.

Levitt, B. \& March, J. G. (1988). Organizational learning. Annual Review of Sociology, 14, 319-340.

Macedo, E. Araújo, H. C., Magalhães, A. \& Rocha, C. (2015). The construction of early school leaving as a political concept under the lenses of sociology of education. Profesorado, 19(3), 28-42.

May, P. (1992). Policy learning and failure. Journal of Public Policy, 12(4), 331-354.

Olsen, P. J. \& Peters, G. P. (1996). Lessons from experience. Experiential learning in administrative reforms in eight democracies. Oslo: Scandinavian University Press.

Pemberton, H. (2003). Learning, governance and economic policy. The British Journal of Politics \& International Relations, 5(4), 500-524.

Pierre, J. \& Peters, G. B. (200o). Governance, Politics and the State. New York: St. Martin's Press.

Radaelli, M. C. (2003). The Open Method of Coordination: A new governance architecture for the European Union? Stockholm: Swedish Institute for European Policy Studies, SIEPS Working Paper, No. 2003:1.

Radaelli, M. C. (2004). Who learns what? Policy learning and the open method of coordination. Paper presented at Economic and Social Research Council Workshop on the Lisbon Strategy, University of Birmingham, 26. November, Birmingham, Great Britain.

Radaelli, M. C. (2008). Europeanization, policy learning, and new modes of governance. Journal of Comparative Policy Analysis, 10(3), 239-254.

Rose, R. (2002). Lesson-drawing in public policy: A guide to learning across time and space. New York: Chatham House Publishers.

Rose, R. (2005). Learning from Comparative Public Policy: A Practical Guide. London: Routledge. 
Sabatier, A. P. (1993). Policy change over a decade or more. In P. R. Lee \& C. L. Estes (Eds.). The Nation's Health (pp. 143-174). London: Jones and Bartlett Publishers Canada.

Steiner-Khamsi, G. (2012). Understanding policy borrowing and lending. Building comparative policy studies. In G. Steiner-Khamsi \& F. Waldow (2012). Policy Borrowing and Lending in Education (pp. 3-17). London: Routledge.

Stone, D. (1999). Learning lessons and transferring policy across time, space and disciplines. Politics, 19(1), 51-59.

Thematic Working Group (n.d.). Data collection on and monitoring of Early School Leaving (ESL). Draft analysis of the results from the mapping exercise on data collection and monitoring of ESL. Retrived from: http://ec.europa.eu/dgs/education_culture/repository/education/policy/ strategic-framework/doc/data-monitoring-esl_en.pdf

Vilpišauskas, R. (2011). Does Europe 2020 represent learning from the Lisbon Strategy? Paper presented at Biannual European Union Studies Association (EUSA) Conference, 3-5 March, Boston, USA.

Volden, C., Ting, M. M. \& Carpenter, D. P. (2008). A formal model of learning and policy diffusion. American Political Science Review, 102(3), 319-332.

Zito, R. A. \& Schout, A. (2009). Learning theory reconsidered: EU integration theories and learning. Journal of European Public Policy, 16(8), 1103-1123. 
2.2 origin and interplay

of ESL-related factors 



\subsection{I}

\section{The Interplay of Factors Contributing to ESL at the Levels of the Individual, the Family and Social Background}

Maša Vidmar and Tina Rutar Leban

\section{Synopsis}

Individual cognitive factors, especially low-achievement patterns, increase the risk for ESL, but non-cognitive factors (e.g. personality traits, problem behaviour) also play a role. At the level of the family and social background, the most prominent risk factor is low SES. However, it is noted that ESLers comprise a heterogeneous group.

\section{Summary}

ESL is a process rather than a one-off event (European Commission, 2011) and the route to ESL frequently begins before the child goes to school (NESSE, 2010). ESL risk and protective factors have to be understood within a multiple-level framework: the individual, the microsystem (e.g. family, peers, school), the mesosystem (relations between the microsystems), the exosystem (e.g. health, social, education system, media, neighbours), the macrosystem (e.g. the culture in which individuals live) and the chronosystem (e.g. sociohistorical circumstances) (see Bronfenbrenner, 1996). ESLers are generally more likely to be exposed to multiple disadvantages at different levels, which usually interact (European Commission, 2011). This article aims to review the literature on several different individual factors and factors related to the family and social background that may contribute or prevent ESL. 
The present scientific review on one hand confirms that already demonstrated in many studies and literature reviews: at the level of individual, cognitive factors it is especially low-achievement patterns which are the most potent for increasing the risk for ESL. Being male and having a migrant/minority status are also risk factors; however, the relationships are less straightforward. On the other hand, the article draws attention to a series of non-cognitive factors and highlights the complex interplay between the cognitive and non-cognitive factors. Conscientiousness plays the role of a protective ESL factor (more strongly for low achievers), while problem behaviour seems to be a risk factor. ESLers typically exert a lower level of achievement motivation and have a history of disengagement from school (e.g. truancy). On a similar note, engagement was shown to reduce the risk of ESL. Among the family and social background factors, low SES is the most consistent and strongest predictor of ESL. In addition, the family's social capital (e.g. parental education support, their involvement, parenting practices, but also family structure) impact the risk of ESL.

The review of factors that contribute to ESL helps understand how highly versatile and individualised interventions, measures and initiatives tackling ESL must be to address the different needs of (potential) ESLers.

Key words: early school leaving, individual factors, family background, social background, achievement, personality, problem behaviour

\section{Introduction}

Along with the EU (European Commission, 2002; Council of the EU, 2009) recognition of ESL as an important political issue with long-lasting consequences for the individual and society, scientific and research attention to the matter has grown, noting that the topic also received some attention earlier, particularly in the USA (see e.g. Barclay \& Doll, 2001 who examined ESL studies conducted between 1950 and 1970). Today, an abundance of publications aims to understand (and prevent) ESL, including numerous scientific studies examining possible ESL risk or protective factors and reviewing the evidence available in existing studies.

Some authors have proposed theoretical models of ESL (e.g. BattinPearson et al., 2000; Fall \& Roberts, 2012; Finn, 1989; Clycq, Nouwen, \& 
Timmerman, 2014; for a review of such models, see Rumberger, 2011). However, ESL can also be viewed within more general theories of human development. For example, Bronfenbrenner's theory (1996) distinguishes several levels of ecological systems that all interact with each other and with the characteristics of the individual: the microsystem (e.g. family, peers, school - most immediate and direct impact), the mesosystem (relationships between the microsystems - e.g. relationships between the family and teachers), the exosystem (e.g. health, social, education system, media, neighbours - indirect impact), the macrosystem (e.g. the culture in which individuals live: attitudes, ideologies) and the chronosystem (e.g. sociohistorical circumstances) (see Figure 8). ESL risk and protective factors can be understood within this multiple-level framework.

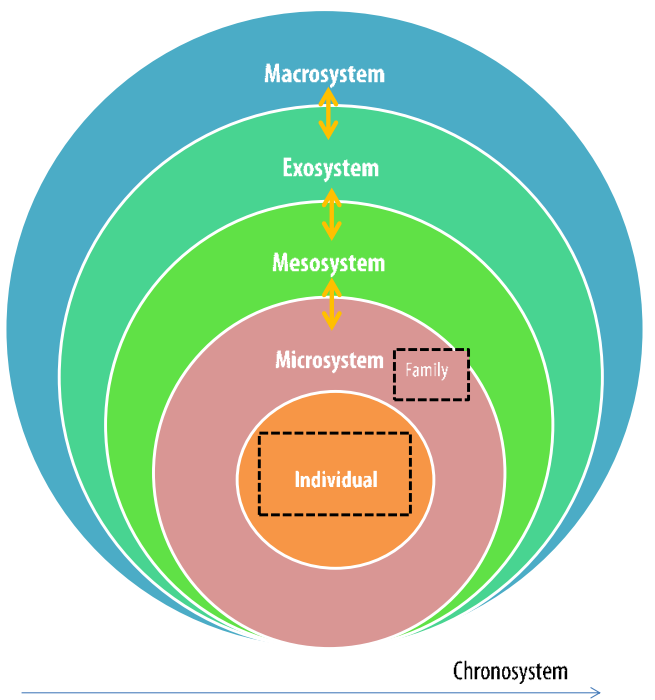

Figure 8. Bronfenbrenner's model of human development. The black rectangles constitute the focus of the article.

This means that ESL is both a process and a complex phenomenon (e.g. Clandinin et al., 2010; Lyche, 2010). Causes (trajectories resulting in ESL) vary from student to student (NESEE, 2010) and may begin very early in one's life (e.g. Jimerson, Egeland, Sroufe, \& Carlson, 200o; McGarr, 2010). However, where several risk factors from multiple levels co-exist, the incidence of ESL is greater (Beekhoven \& Dekkers, 2005; European Commission, 2011; McGarr, 2010). Understanding the interplay of factors 
(i.e. that ESL does not result from interpersonal factors alone) and levels is essential. Several studies have attempted to model this complexity and map the underlying processes that influence ESL (e.g. Traag \& van der Velden, 2008).

In the present article, we focus on the ESL factors lying within the individual and the microsystem (focusing on the family level) and review relevant scientific evidence'. Many authors have developed own classifications of ESL microsystem factors that more or less overlap (e.g. students and institutional characteristics, Rumberger \& Lim, 2008; individual, family and school characteristics, Traag \& van der Velden, 2008; school-based and individual, family and social background-related; Thibert, 2013; individual, family, peer, community effects, Audas \& Willms, 2001). These categories can be further sub-divided, e.g. individual characteristics are: educational performance, behaviours, attitudes and background (Rumberger \& Lim, 2008); cognitive and non-cognitive (Traag \& van der Velden, 2008). In this article, we classify factors as: (1) those related to an individual (further divided into structural, cognitive and non-cognitive); and (2) those related to the family and social background.

As mentioned, a wealth of publications can already be found covering ESL individual and family factors: Yet this article tries to bring together what has already been done by way of a structured and coherent presentation. Some factors highlighted in the article are discussed and reviewed in greater depth in separate articles (e.g. low motivation, poor academic achievement, behavioural problems and home environment).

\section{Methodology}

The scientific review article is based on computerised literature searches in the Arizona State University Library search engine coupled with other online resources (e.g. Google Scholar). We used the following key words "early school leaving", "drop out" AND "individual factors/precursors/determinants", "motivation", "academic achievement", “engagement", "personality", "non-cognitive factors", "family factors", "family characteristics", "parental involvement", "parental aspirations", "parental support", "metaanalysis". In the next step, we examined references cited in the articles (i.e., "backward search" procedures). Original scientific articles and

1 School-level factors (also a microsystem) and factors from the exosystem are examined in two separate articles. 
monographs as well as reports by or for the European Commission and the OECD are considered.

\section{Factors related to the individual}

This group of ESL factors has been very extensively studied. A considerable body of research also deals with factors not specifically related to ESL, but to academic achievement (mostly not covered in this article due to its focus on ESL, albeit the precursors of low academic achievement often overlap with those of ESL; simultaneously, low achievement is itself a strong risk factor for ESL). Individual-level factors can be classified in three groups: structural (i.e. demographic, e.g. gender, minority/migrant background), cognitive (e.g. academic achievement, intelligence) and non-cognitive (e.g. personality traits, social competence, emotional competence/intelligence, problem behaviour, motivation, engagement, self-concept, anxiety).

\section{Structural factors: gender}

With regard to gender, a consistent pattern is found - young males are at greater risk for ESL than their female counterparts. According to Eurostat, the ESL rate in 2016 was 3.0 percentage points higher for young men (12.2\%) than for young women (9.2\%) in the EU-28 (Eurostat, n.d. a). Thus, the proportion of early leavers among young men is about $30 \%$ higher than among young women, a ratio that has been stable over the last decade (ibid.). In almost all EU countries, the rates were higher for males than females, in some countries even by up to $5 \%$. Similar findings were reported in international and national research (e.g. Audas \& Willms, 2001; Brock, 2011; Houses of the Oireachtas, 2010; Marks \& McMillian, 2001; NESSE, 2010; Traag \& van der Velden, 2008). Several tentative explanations are provided for this: boys have lower achievement in reading than girls; boys have more difficulties adapting to the school environment than girls; gender is more likely to play a role for boys from a poor neighbourhood, while the gender difference for students from a better situated neighbourhood seems to be non-significant (see European Commission/EACEA/Eurydice/Cedefop, 2014 for details). Thus, the relationship between ESL and gender seems to be less straightforward than the relationship with social economic status (SES), indicating that gender alone is not a determining factor. 


\section{Structural factors: migrant and minority background ${ }^{2}$}

Eurostat data show that students born abroad are largely over-represented among those who leave formal education prematurely in many EU countries - the share of early leavers among migrants in 2015 was almost twice the level for natives (19.0\% compared with 10.1\%) (Eurostat, n.d. b), and can be up to five times more in some countries (European Commission/EACEA/ Eurydice/Cedefop, 2014). There are several possible reasons for this, including low SES and language difficulties that may lead to low achievement and low motivation. Indeed, the European Commission (2014) as well as the OECD (2013) consistently report lower levels of academic performance for migrant compared to native students, although the difference shrinks (but remains significant) when controlling for SES.

On the contrary, in a study by Traag and van der Velden (2008) students from a migrant background were less at risk for ESL when controlling for social background (family resources) than their native counterparts. According to the authors, this means that the larger numbers of migrant students found among ESLers is not due to cultural differences and language proficiency, but due to the lack of family resources (they more often have low SES). Interestingly, in Australia having an Australian-born parent (i.e. a native background) increased the risk for ESL compared to students whose parents were born in non-English-speaking countries (Marks \& McMillian, 2001).

Among the students with a minority background, it is Roma students who have been most widely studied. The ESL rates among young Roma are extremely high - in the examined 11 EU member states only $15 \%$ of young Roma adults surveyed complete upper-secondary general or vocational education (FRA/UNDP, 2012). A combination of factors (e.g. parental choice, poverty, language barriers, ethnic discrimination in institutions) is likely to underlie this (European Commission/EACEA/Eurydice/Cedefop, 2014; Eurostat, n.d. b).

Despite the data shown above, it is important to note that students with a migrant/minority background constitute a heterogeneous group (e.g. different ethnic backgrounds, second-generation migrants versus new arrivals), thus it seems that other factors play a more critical role

2 As indicated in the European Commission/EACEA/Eurydice/Cedefop report (2014) different countries have different conceptualization of what it means to have a migrant to minority background, making comparison difficult; however, some conclusions can still be made. 
in educational outcomes than migrant background per se (European Commission/EACEA/Eurydice/Cedefop, 2014).

\section{Cognitive factors}

Low abilities (e.g. intelligence), low academic achievement, low knowledge gained in primary education are identified as the most potent risk factors for ESL (see the reviews in Barclay \& Doll, 2001; Battin-Pearson et al., 2000; Jugović \& Doolan, 2013; Lyche, 2010; NESEE, 2010; McCarthy Voss, 2015; for an exception, see Brock, 2011). ESLers also tend to be less intelligent and have lower scholastic achievement (see the review in Traag \& van der Velden, 2008). Traag (2012) found significant differences between ESLers and their counterparts finishing secondary education on cognitive factors, like text comprehension, arithmetic and information processing. Moreover, a logistic regression showed that the higher a student scored on the cognitive test, the lower was the risk of becoming an ESLer. The impact of cognitive factors remained significant, but was reduced after including the control variables (e.g. SES, migrant background). On a similar note, Marks and McMillian (2001) found cognitive factors like literacy and numeracy in middle school had a strong influence on subsequent ESL. Janosz, LeBlanc, Boulerice and Tremblay (1997) found school achievement to be the best screening variable for potential ESLers. In a review by Rumberger and Lim (2008), a majority of 200 studies found that academic achievement had a statistically significant effect on the likelihood of ESL. Further, not doing well at school was an important reason for over $40 \%$ of Australian ESLers (Marks \& McMillian, 2001). Similar findings were reported for ESLers in Europe: when interviewed, students listed having poor results or not feeling smart enough as one of the reasons for ESL (GHK Consulting, 2011).

\section{Non-cognitive factors}

Even though SES and academic achievement have been shown to be the strongest and most consistent precursors of ESL, one should not neglect the role of non-cognitive factors (e.g. personality traits, motivational, affective, social and behavioural characteristics, attitudes). For example, Traag (2012) cited studies highlighting the importance of non-cognitive skills for labour market outcomes (e.g. wage) as well as for the individual's trajectories after ESL (also see Entwisle, Alexander, \& Olson, 2004). 
Personality traits are defined within the Five Factor Model (FFM; McCrae \& Costa, 1997) as extraversion, agreeableness, emotional stability/ neuroticism, conscientiousness, and openness to experience 3 . Personality traits are usually not examined relative to ESL, but to academic achievement (for exceptions, see Rosenthal, 1998; Traag, 2012). Conscientiousness was found to be protective factor against ESL, while openness to experience, on the contrary to the author's expectations, increased the risk of ESL (other personality traits were not significant predictors after controls were added to the models; Traag, 2012). In relation to academic achievement, conscientiousness (in some studies in combination with openness) was the most consistent predictor (e.g. Poropat, 2009; Lamb, Chuang, Wessels, Broberg, \& Hwang, 2002; Zupančič \& Kavčič, 2007) while research results about openness to experience, emotional stability, and agreeableness are inconclusive (for a review, see Traag, 2012; Vidmar, 2010). Extraversion was a positive predictor for both young children and young adolescents (e.g. Anthony, 1983; Eysenck \& Cookson, 1969; Mervielde, Buyst \& De Fruyt, 1995), but a negative one in older age groups (e.g. Eysenck, 1994; Mervielde et al., 1995; Puklek Levpušček \& Zupančič, 2009; Smrtnik Vitulić, 2008; Wolf \& Ackerman, 2004).

Student engagement is one of the most important precursors to ESL in conceptual models of ESL (Finn, 1989; Rogers, 2016; Rumberger \& Lim, 2008). Disengagement from education lies along a continuum that at the most extreme end refers to ESL (Rogers, 2016; Rumberger, 2011). It comprises multiple dimensions: an emotional (e.g. affective reactions) and behavioural dimension (e.g. absenteeism, participation in learning and academic tasks) and in some models also a cognitive one (e.g. willingness to exert effort; for details, see Archambault, Janosz, Fallu, \& Pagani, 2009; Rogers, 2016). Indeed, in high school stronger levels of engagement reduced the ESL risk in the majority of studies ( $77 \%$, non-significant in the remaining studies), while the impact of engagement was less obvious in middle school (Rumberger \& Lim, 2008). Audas and Willms' (2001) and Lyche's (2010) literature review (2001), McCarthy Voss' study (2015) and the study by Henry,

3 Extraversion is conceptualized in terms of sociability, activity, positive mood, assertiveness; agreeableness in terms of prosocialness, kindness, courtesy, empathy, compliance, cooperation; neuroticism in terms of general negative emotionality, high sensitivity, high arousal, the presence of fears, tension, anxiety; conscientiousness in terms of controlling impulses, maintaining attention, accuracy, orderliness, determination, competitiveness; and openness in terms of curiosity, creativity, interest in new things, cleverness, ingenuity, and speed of learning (Ehrler, Evans, \& McGhee, 1999; Zupančič \& Kavčič, 2007). 
Knight and Thornberry (2012) confirm the importance of engagement for ESL as ESLers had a history of disengagement from school (e.g. absence, truancy, expulsion; NESSE, 2010). In a study by Janosz, Archambault, Morizot and Pagani (2008), ESLers demonstrated unstable pathways of school engagement (transitory increasing, transitory decreasing, decreasing, and increasing trajectories). Archambault et al. (2009) found that global engagement and its behavioural dimension were significant predictors of ESL (also see Janosz et al., 1997). In Wang and Fredricks' study (2014), lower behavioural and emotional engagement was predictive of a higher ESL rate. The perceived fit between students and the school's social environment plays a central role in school engagement (Järvinen, Soini, Pyhältö, \& Pietarinen, 2012).

Closely linked to student engagement, another important non-cognitive factor is motivation (European Commission, 2014). To some extent, motivational differences are partly reflected by differences in conscientiousness, but these differences are more general across contexts and situations; thus, in this section we focus specifically on motivation in a learning and achievement-related setting. Motivation to perform well in school was significantly lower for ESLers compared to regular school leavers, but the differences were quite small compared to the differences in cognitive skills; regardless of this, a high score on achievement motivation decreased the risk of becoming an ESLer (Traag, 2012). The size of the impact remained unchanged even when including background variables (SES, migrant status). Bridgeland, DiIulio and Morison (2006) surveyed actual ESLers and $69 \%$ of the respondents identified a lack of motivation as a reason for dropping out and a similar share was confident they would have graduated if they had tried. Lack of motivation in ESLers was also found by Beekhoven and Dekkers (2005).

Negative attitudes to school (e.g. not liking school, disconnectedness from school) are a non-cognitive factor that occurs at higher rates in ESLers. For example, not liking school was cited as a reason for ESL by $50 \%$ of ESLers in Australia; although wanting to get a job/ apprenticeship was more frequent and more important (Marks \& McMillian, 2001). Similarly, ESLers in Europe experience school rules and regulations in a negative way and list this as a reason for ESL (GHK Consulting, 2011). The literature review by Audas and Willms (2001) supports this - ESLers feel disconnected from school, believe their teachers do not care about them, and think the 'cards are stacked against them'. 
Social competence and problem behaviour are also considered non-cognitive factors of ESL (European Commission, 2014). Behavioural problems lead to poor school performance or may be a consequence of frustrations due to keeping up with school work or maintaining an interest in school work or an unsupportive environment more generally (ibid.). Based on a review of studies, Rumberger and Lim (2008) concluded that any of the deviant behaviours (e.g. misbehaving in school, delinquent behaviour outside of school, drug and alcohol use, and sexual activity and teen childbearing) increased the risk for ESL. Literature reviews by Audas and Willms (2001), Barclay and Doll (2001), Lyche (2010) and Hymel and Ford (2014) support this. Ensminger and Slusarcick (1992) found that aggressive behaviour as early as first-grade increased the risk of ESL for boys, Brock (2011) found a similar effect for hyperactive and inattentive behaviours of 12-yearolds (also see Janosz et al., 1997; Jimerson et al., 2000; Vitaro, Brendgen, \& Tremblay, 1999). Carter (1998) demonstrated that ESLers have lower social competence than those who persist in school.

Another set of non-cognitive factors was examined by Bradshaw, O’Brennan, \& McNeely (2008). In their literature review study, they highlighted the following protective factors against ESL: a positive sense of self, self-control (e.g. impulse control, and delay of gratification locus of control), decision-making skills (e.g. responsible decisions about studying and completing assignments, social and emotional problem solving, relationship skills), empathy and perspective taking, and connectedness to parents, teachers.

The findings of a comprehensive study by Wang, Haertel, \& Walberg (1993) which dealt more widely with factors supporting students' school learning (not specifically ESL factors) are in line with the examined studies. They identified the importance of psychological factors, including motivational, affective, social and behavioural (in addition to cognitive and metacognitive) student characteristics.

\section{Interplay of cognitive and non-cognitive factors}

Based on the scientific evidence presented above, it seems that cognitive factors have a strong and direct effect on the risk of ESL, and that this effect remains after adding non-cognitive factors. However, non-cognitive skills also explain part of the individual differences in ESL risk (Traag, 2012). Traag (2012) found that non-cognitive factors play an important role in understanding why some students leave school even though their cognitive 
skills are at an adequate level (e.g. high openness to experience was a risk factor for those with high cognitive skills, and a protective factor for those with low cognitive skills). She also found that conscientiousness was a strong protective factor for those with low cognitive skills, but was not significant for students with above-average cognitive skills. The results indicate that non-cognitive skills play a role after controlling for cognitive factors, yet the effects are not merely additive - there is a complex interplay between the two factors. Another way of explaining the interplay is that cognitive and some non-cognitive characteristics develop along mutually related lines; e.g. successful performance in certain tasks increases interest and thus increases motivation (ibid.).

\section{Factors related to the family and social background}

Traag and van der Velden (2008) categorised family factors into four groups that also cover social background: economic capital (i.e. financial resources), human capital (parental education levels), social capital and cultural capital. The first two can be combined into what is operationalised in many studies as socio-economic status (SES) - SES is also used in this article. Social capital refers to the relationship between parents and children (e.g. parental involvement, parental educational aspirations, parental educational support, domestic violence, parenting style), including family composition (single-parent or two-parent) and number of children. The cultural capital refers to cultural participation (e.g. visits to museums, concerts and the theatre).

\section{SES}

Among ESL factors, low SES (i.e. low household income, unemployed parents, low level of parental education) seems to be the most consistent risk factor. As indicated in the European Commission/EACEA/Eurydice/Cedefop (2014) and NESSE (2010) reports, many studies have found low SES to entail key factors that increase the risk of ESL (also see Audas \& Willms, 2001; Brock, 2011; Jugović \& Doolan, 2013; Houses of the Oireachtas, 2010; Janosz et al., 1997; Jimerson et al., 2000; Marks \& McMillan, 2001; Rosenthal, 1998; Traag, 2012). ESLers are much more likely to come from families with low SES. For example, the majority (over 70\%) of ESLers have parents with a low level of education (compulsory or below) (GHK Consulting, 2011). The importance of parental education for student attainment is consistently shown in the PISA study (e.g. OECD, 2012, 2013, 2016). The role of SES in 
ESL was also highlighted in a review for the European Commission (2014). Boudon's theory of social stratification (Boudon, 1974) can explain these findings - for individuals from a lower social class the cost of staying at school is relatively large while at the same time less importance is attributed to education than among those from high social classes - this makes education less worthwhile for students from low SES groups and increases their chances of ESL.

\section{Social capital}

Parental education support (e.g. parents have discussions about school and school performance and give compliments about school performance) is an important predictor of ESL; having highly supportive parents cuts the risk of ESL by more than 50\% compared to a very unsupportive parent (Traag \& van der Velden, 2008). Brock (2011) also found parental support to be an important ESL predictor. Home educational support of students in schools of a similar socioeconomic composition was important for ESL; students with more educational resources at home were less likely to intend to leave school than students with fewer home resources in schools with a similar socioeconomic composition (Houses of the Oireachtas, 2010).

Parental attitudes in the first grade (i.e. conduct expected, mark expected, education expected) predicted ESL, while the prediction of parenting socialisation practices was not significant (Alexander, Entwisle, \& Horsey, 1997). In relation to parental involvement, a metaanalysis (Jeynes, 2005) found a considerable and consistent relationship between parental involvement and academic achievement (regardless of the measure of achievement). The relationship held across race and gender. Very interesting findings included that some of the most powerful aspects of parental involvement were the more subtle ones - those that create the general atmosphere. Parental high expectations of school performance and parenting style and not particular actions (e.g. checking homework, attending school functions) were significant predictors (ibid.). The European Commission (2014) in its literature review also found a violent family atmosphere to be related to an increased risk of ESL. Similarly, Tiko's study (2008) showed that the family's inability to support the child and enable the conditions for learning (e.g. lack of interest in the child, alcoholism) is one of the key reasons for students' underachievement and non-compliance with compulsory schooling. Based on their literature review, Bradshaw et al. (2008) concluded that the connection to one's parents has a positive influence 
on multiple aspects of youth development, including ESL. Jimerson et al. (2000) demonstrated the importance of the early home environment in the toddler years (e.g. parental emotional and verbal responsivity, acceptance of the child's behaviour, provision of appropriate play material) and parental involvement in primary school for subsequent ESL.

Moreover, other indicators of social capital were found to play a role in ESL. Children from single-parent families and children in families with four or more children were at a higher risk for ESL (Audas \& Willms, 2001; Traag \& van der Velden, 2008). In other studies, family composition was linked to a student's academic achievements; children from single-parent families had lower school performance than their two-parent counterparts (Babarović, Burušić, \& Šakić, 2009). Similarly, on average across the OECD, students from single-parent families have lower scores in PISA than students from other types of families after accounting for socio-economic background (OECD, 2010).

\section{Cultural capital}

Cultural participation (parent reports visiting museums, concerts and theatre) decreases the chances of ESL (Traag \& van der Velden, 2008). Cultural capital is also integrated in PISA's measure of SES. It is called economic, social and cultural status and derives from four variables (i.e. parent's highest level of education, parent's highest occupation status, home possessions and books in the home), one of them tapping cultural capital. A clear link to student academic achievement was demonstrated in all cycles of the PISA study (e.g. OECD, 2016). The role of the cultural participation is that it potentially leads to a close link between a student's behaviour and views on the dominant school culture and decreasing the ESL risk (Traag \& van der Velden, 2008). The issue of cultural capital as necessarily resembling the dominant culture seems problematic; it seems that a culturally-sensitive curriculum is also warranted.

\section{Conclusion}

The present scientific review on one hand confirms that already demonstrated in many studies: at the level of the individual, cognitive factors especially low achievement patterns, most consistently and strongly increase the risk for ESL (although academic performance does not account for all of the variance between students who persist in school and ESLers). Being 
male and having a migrant/minority status are also risk factors: however, the relationships are not straightforward. On the other hand, the article draws attention to a series of non-cognitive factors and highlights the complex interplay of the cognitive and non-cognitive factors. Conscientiousness plays the role of a protective ESL factor (more strongly for low achievers), while problem behaviour seems to be a risk factor. Achievement motivation is also important. Within family and social background factors, SES is the most consistent and strongest predictor. In addition, the family's social capital (e.g. parental education support, their involvement, parenting practices, but also family structure) impacted the risk of ESL.

When planning interventions or policy changes targeting ESL, it is important to note what Wand et al. (1993) observed: in general, proximal variables (e.g., psychological, instructional) were more important for students' learning than distal variables (e.g., policy and organisation). This implies that introducing new policies (at the state or school level) will not necessarily enhance student learning. Thus, whenever introducing policies aimed at the protective or risk factors of ESL, it should be ensured that distal variables become translated into changes for the student.

Finally, interventions to combat ESL need to be based on an understanding of its complex determinants and the factors that operate at multiple levels and vary from one student to another - ESLers are a very heterogeneous group (no single 'profile' can be established). The impact of factors related to ESL may vary for different subgroups. Interventions therefore need to address issues pertaining to the individual, the microsystem (family, school, teachers and other educators) and the exosystem (education system) in a co-ordinated way. Attention to the mesosystem should not be overlooked; e.g. developing a home-school mesosystem that is supportive of the student and his/her school attendance. Moreover, the fact the developmental pathway to ESL may already begin in elementary school or even before then is important.

\section{References}

Alexander, K. L., Entwisle, D. R., \& Horsey, C. S. (1997). From first grade forward: Early foundations of high school dropout. Sociology of Education, $70(2), 87-107$.

Anthony, W. S. (1983). The development of extraversion and ability: Analysis of data from a large-scale longitudinal study of children tested at 10-11 and 14-15 years. British Journal of Educational Psychology, 53, 374-379. 
Archambault, I., Janosz, M., Fallu, J., \& Pagani, L. S. (2009). Student engagement and its relationship with early high school dropout. Journal of Adolescence, 32(3), 651-670.

Audas, R., \& Willms, J. D. (2001). Engagement and dropping out of school: A life course perspective. Working paper for the Applied Research Branch, Strategic Policy, Human Resources Development.

Babarović, T., Burušić, J., \& Šakić, M. (2009). Uspješnost predviđanja obrazovnih postignuća učenika osnovnih škola Republike Hrvatske [Prediction of the educational achievements of primary school pupils in the Republic of Croatia]. Društvena istraživanja, 18(4-5), 673-695.

Barclay, J. R., \& Doll, B. (2001). Early prospective studies of the high school dropout. School Psychology Quarterly, 16(4), 357-369.

Battin-Pearson, S., Newcomb, M., Abbott, R., Hill, K., Catalano, R., Hawkins, J., \& Pressley, G. Michael (2000). Predictors of early high school dropout: A test of five theories. Journal of Educational Psychology, 92(3), 568-582.

Beekhoven, S., \& Dekkers, H. (2005). Early school leaving in the lower vocational track: triangulation of qualitative and quantitative data. Adolescence, 4O(157), 197-213.

Boudon, R. (1974). Education, opportunity and social inequality. John Wiley: New York.

Bradshaw, C. P., O’Brennan, L. M., \& McNeely, C. A. (2008). Core competencies and the prevention of school failure and early school leaving. In N. G. Guerra \& C. P. Bradshaw (Eds.), Core competencies to prevent problem behaviors and promote positive youth development. New Directions for Child and Adolescent Development, 122, 19-32.

Bridgeland, J., DiIulio, J., \& Morison (2006). The silent epidemic: Perspectives of high school dropouts. Civic Enterprises, LLC, Washington.

Brock, E. (2011). Who is accountable for high school dropout? A study of the personal, parental, and teacher related factors of elementary students as predictors of high school dropout. Ottawa, Canada: Library and Archives Canada. Retrieved from http://ijecer.net/pfi-depo/vinz/erin.pdf

Bronfenbrenner, U. (1996). The ecology of human development experiments by nature and design. Cambridge, MA: Harvard University Press.

Carter, J. C. (1998). The relationship between at-risk students' resilience and dropout behavior. Doctoral dissertation, University of North Carolina at Chapel Hill. 
Clandinin, D. J., Steeves, P., Li, Y., Mickelson, J. R. Buck, G. Pearce, M., ... Huber, M. (2010). Composing lives: A narrative account into the experiences of youth who left school early. Retrieved from https://www.researchgate. net/publication/265306620_Composing_Lives_A_Narrative_Account_ into_the_Experiences_of_Youth_Who_Left_School_Early_1

Clycq, N., Nouwen, W., \& Timmerman, C. (2014). Theoretical and methodological framework on Early School Leaving. Project Paper 2 RESL.eu-project. Retrieved from https://www.uantwerpen.be/images/uantwerpen/container 2316o/files/Project\%2oPaper\%202\%20-\%2ofinal\%2oversion\%20-\%20 09\%2005\%202014.pdf

Council of the EU. (2009). Council conclusions of 12 May 2009 on a strategic framework for European cooperation in education and training ("ET 2020”). Retrieved from http://eur-lex.europa.eu/legal-content/EN/TXT/ $\mathrm{PDF} /$ ?uri=CELEX:52009XG0528(01)\&from=EN

Ehrler, D. J., Evans, G. J., \& McGhee, R. L. (1999). Extending big-five theory into childhood: A preliminary investigation into the relationship between bigfive personality traits and behavior problems in children. Psychology in the Schools, 36(6), 451-458.

Ensminger, M. E., \& Slusarcick, A. L. (1992). Paths to high school graduation or dropout: A longitudinal study of a first-grade cohort. Sociology of Education, 65(2), 95-113.

Entwisle, D., Alexander, K., \& Olson, L. (2004). Temporary as compared to permanent high school dropout. Social Forces, 82(3), 1181-1205.

European Commission (2002). Communication from the Commission: European benchmarks in education and training: Follow-up to the Lisbon European Council. Retrieved from http://eur-lex.europa.eu/LexUriServ/ LexUriServ.do?uri=COM:2002:0629:FIN:EN:PDF

European Commission (2011). Tackling early school leaving: A key contribution to the Europe 2020 Agenda. Retrived from http://eur-lex.europa.eu/ LexUriServ/LexUriServ.do?uri=COM:2011:0018:FIN:EN:PDF

European Commission (2014). Study on the effective use of early childhood education and care in preventing early school leaving: Annex 1. Literature review ( $\mathrm{N}^{\circ}$ EAC/17/2012). Luxembourg: Publications Office of the European Union.

European Commission/EACEA/Eurydice/Cedefop (2014). Tackling early leaving from education and training in Europe: Strategies, policies and measures. Eurydice and Cedefop Report. Luxembourg: Publications Office of the European Union. 
Eurostat (n.d., a). Early leavers from education and training. Retrieved from http://ec.europa.eu/eurostat/statistics-explained/index.php/ Early_leavers_from_education_and_training\#Analysis_by_sex

Eurostat (n.d., b). Europe 2020 indicators - education. Retrieved from http://ec.europa.eu/eurostat/statistics-explained/index.php/ Europe_2020_indicators_-_education\#cite_note-3

Eysenck, H. J. (1994). Personality and intelligence: Psychometric and experimental approaches. In R. J. Sternberg \& P. Ruzgis (Eds.), Personality and intelligence (pp. 3-31). New York: Cambridge University Press.

Eysenck, H. J., \& Cookson, D. (1969). Personality in primary school children: 1. Ability and achievement. British Journal of Educational Psychology, 39, 109-122.

Fall, A., \& Roberts, G. (2012). High school dropouts: Interactions between social context, self-perceptions, school engagement, and student dropout. Journal of Adolescence, 35(4), 787-798.

Finn, J. D. (1989). Withdrawing from school. Review of Educational Research, 59(2), 117-142.

FRA/UNDP (2012). The situation of Roma in 11 EU Member States. Luxembourg: Publications Office of the European Union.

GHK Consulting (2011). Study on reducing early school leaving in the EU (p. 350). DGEAC. Retrieved from http://www.europarl.europa.eu/studies

Henry, K. L., Knight, K. E., \& Thornberry, T. P. (2012). School disengagement as a predictor of dropout, delinquency, and problem substance use during adolescence and early adulthood. Journal of Youth and Adolescence, 41(2), 156-166.

Houses of the Oireachtas (2010). Staying in education: A new way forward school and out-of-school factors protecting against early school leaving. Joint Committee on Education and Skills, First Report. Retrieved from http://www.oireachtas.ie/documents/committees3othdail/j-educationscience/reports_2008/20100525.pdf

Hymel S., \& Ford L. (2014). School completion and academic success: The impact of early social-emotional competence. In: R. E. Tremblay, M. Boivin, R. Peters (Eds.), F. Vitaro F. (topic ed.) Encyclopedia on Early Childhood Development [online]. Retrieved from http:// www.child-encyclopedia.com/school-success/according-experts/ school-completion-and-academic-success-impact-early-social 
Janosz, M., Archambault, I., Morizot, J., \& Pagani, L. (2008). School engagement trajectories and their differential predictive relations to dropout. Journal of Social Issues, 64(1), 21-40.

Janosz, M., LeBlanc, M., Boulerice, B., \& Tremblay, R. (1997). Disentangling the weight of school dropout predictors: A test on two longitudinal samples. Journal of Youth and Adolescence, 26(6), 733-762.

Järvinen, S., Soini, T., Pyhältö, K., \& Pietarinen, J. (2012). Peer group resource or impediment for pupils' academic engagement? Function of peer group for 6th and 8th graders academic engagement. Paper presented at the European Conference on Educational Research, Cadiz, Spain. Retrieved from: http://www.eera-ecer.de/ecer-programmes/conference/6/ contribution/17297/

Jeynes, W. (2005). A meta-analysis of the relation of parental involvement to urban elementary school student academic achievement. Urban Education, 40(3), 237-269.

Jimerson, S., Egeland, B., Sroufe, L. A. \& Carlson, B. (2000). A prospective longitudinal study of high school dropouts examining multiple predictors across development. Journal of School Psychology, 38(6), 525-549.

Jugović, I., \& Doolan, K. (2013). Is there anything specific about early school leaving in Southeast Europe? A review of research and policy. European Journal of Education, 48(3), 363-377.

Lamb, M. E., Chuang, S. S., Wessels, H., Broberg, A. G., \& Hwang, C. P. (2002). Emergence and construct validation of the Big Five factors in early childhood: A longitudinal analysis of their ontogeny in Sweden. Child Development, 73(5), 1517-1524.

Lyche, C. (2010). Taking on the completion challenge: A literature review on policies to prevent dropout and early school leaving. OECD Education Working Papers, 53, OECD Publishing.

Marks, G., \& McMillian, J. (2001). Early school leavers: Who are they, why do they leave, and what are the consequences? Australian Council for Educational Research, 8. Retrieved from http://research.acer.edu.au/ research_conference_2001/2/

McCarthy Voss, J. C. (2015). School attrition and dropout recovery ameliorated by literacy, engagement, and resilience. Doctoral dissertation. Eastern Michigan University, Ypsilanti, Michigan.

McCrae, R. R., \& Costa, P.T. (1997). Personality trait structure as human universal. American Psychologist, 52(5), 509-516. 
McGarr, J. (2010). Early school leaving: An exploration of the factors contributing to school non-completion. Master's thesis, Dublin Institute of Technology.

Mervielde, I., Buyst, V., \& De Fruyt, F. (1995). The validity of the Big-Five as a model for teacher's ratings of individual differences among children aged 4-12 years. Personality and Individual Differences, 18, 525-534.

NESSE (2010). Early school leaving: Lessons from research for policy makers. European Commission.

OECD (2010). PISA 2009 Results: Overcoming Social Background - Equity in Learning Opportunities and Outcomes (Volume II). Paris: OECD Publishing. Retrieved from http://www.oecd.org/pisa/pisaproducts/48852584.pdf

OECD (2012). Equity and quality in education: Supporting disadvantaged students and schools. Paris: OECD.

OECD (2013). PISA 2012 results: Excellence through equity: Giving every student the chance to succeed (Volume II). Paris: OECD Publishing.

OECD (2016). PISA 2015 results (Volume I): Excellence and equity in education. Paris: OECD Publishing.

Poropat, A. E. (2009). A meta-analysis of the five-factor model of personality and academic performance. Psychological Bulletin, 135(2), 322-338.

Puklek Levpušček, M., \& Zupančič, M. (2009). Osebnostni, motivacijski in socialni dejavniki učne uspešnosti [Personality, motivational and social factors of academic achievement]. Ljubljana: Znanstvenoraziskovalni inštitut Filozofske fakultete.

Rogers, L. (2016). Disengagement from education. London: Institute of Education Press.

Rosenthal, B. S. (1998). Non-school correlates of dropout: An integrative review of the literature. Children and Youth Services Review, 20(5), 413-433.

Rumberger, R. W. (2011). Dropping out: Why students drop out of high school and what can be done about it. Cambridge, MA, USA: Harvard University Press.

Rumberger, R., \& Lim, S. (2008). Why students drop out of school: A review of 25 years of research. California Dropout Research Project Report \#5. Retrieved from http://uchilishteto.org/data/researchreport15.pdf

Smrtnik Vitulić, H. (2008). Razvoj strukture osebnosti pri mladostnikih in njena vloga pri napovedi učnih dosežkov [The development of personality structure in adolescents and its role for academic achievement]. Unpublished doctoral dissertation, Faculty of Arts, University of Ljubljana, Ljubljana. 
Thibert, R. (2013). Early school leaving: Different ways to deal with it. Dossier d'actualité Veille et Analyses IFÉ, 84. Lyon: ENS de Lyon. Retrieved from http://ife.ens-lyon.fr/vst/DA-Veille/84-may-2013_EN.pdf

Tiko, A. (2008). Underachievement in the first grade - Challenge for cooperation between Estonian social and educational system. In U. Härkönen \& E. Savolainen (Eds.), International Views on Early Childhood Education (pp. 1-11). Savolinna: University of Joensuu. Retrieved from http://sokl. uef.fi/verkkojulkaisut/varhais/tiko.pdf

Traag, T. (2012). Early school-leaving in the Netherlands. A multidisciplinary study of risk and protective factors explaining early school-leaving. The Hague: Statistics Netherlands.

Traag, T., \& van der Velden, R. K. W. (2008). Early school-leaving in the Netherlands. The role of student-, family- and school factors for early school-leaving in lower secondary education. Maastricht: Research Centre for Education and the Labour Market.

Vidmar, M. (2010). Dejavniki socialnega vedenja in učne uspešnosti v srednjem otroštvu. [The precursors of social behavior and academic achievement in middle childhood. Unpublished doctoral dissertation]. Unpublished doctoral dissertation, Faculty of Arts, University of Ljubljana, Ljubljana.

Vitaro, F., Brendgen, M., \& Tremblay, R. E. (1999). Prevention of school dropout through the reduction of disruptive behaviors and school failure in elementary school. Journal of School Psychology, 37(2), 205-226.

Wang, M. C., Haertel, G. D., \& Walberg, H. J. (1993). Toward a knowledge base for school learning. Review of Educational Research, 63(3), 249-294.

Wang, M., \& Fredricks, J. (2014). The reciprocal links between school engagement, youth problem behaviors, and school dropout during adolescence. Child Development, 85(2), 722-737.

Wolf, M. B., \& Ackerman, P. L. (2004). A meta-analytic investigation of extraversion and intelligence: An examination of age and sex as moderator variables. Paper presented at the Occasional Temperament Conference, Athens, GA, USA.

Zupančič, M., \& Kavčič, T. (2007). Otroci od vrtca do šole: razvoj osebnosti in socialnega vedenja ter učna uspešnost prvošolcev [Children from preschool to school: Development of personality and social behaviour and academic achievement of first-graders]. Ljubljana: Znanstvenoraziskovalni inštitut Filozofske fakultete. 


\section{2 .2}

\section{The Interplay of Factors Contributing to ESL at the School Level}

Maša Vidmar and Tina Rutar Leban

Synopsis

Although ESL is impacted by the composition of a school (e.g. mean SES) and its structure (e.g. size), school practices, especially the way curriculum is delivered in practice as well as caring, supportive and respectful teachers (and other school staff) who believe in students' ability to succeed, seem particularly important for ensuring (potential) ESLers remain in school.

\section{Summary}

In recent decades, a growing body of literature has identified factors at the school level related to ESL. The aim of this article is to review the empirical research in the field and show a variety of school factors that may contribute to becoming an ESLer. Research indicates that schools can make a difference in students' ability to persist in school. The specific characteristics of school composition (e.g. mean SES, share of students with a minority/migrant background) and school structure (e.g. size, private/public) were found to impact ESL, but these effects are likely confounded with other school characteristics, particularly school practices.

With regard to school practices, ESLers (or those at risk) often report experiencing the curriculum as too complicated, too academic, and disconnected from real life. Innovative provision of the curriculum 
is called for - different pedagogic approaches are proposed (e.g. recognition of informal learning, the use of technology, collaborative approaches through outdoor activities, teaching through arts and sports). Moreover, within the context of the school climate, caring, supportive and respectful teachers (along with other school staff) who believe in students' ability to academically succeed have a significant impact on the lives of students at-risk for ESL and their decision to remain at school. The opposite effect was found for splits in the communication between students and teachers. Students encounter important support or discouragement already in everyday school activities and interactions, thus financial resources or time outside the classroom is not required. Interestingly, a climate of respect and caring is often intended or assumed by the adults; however, it is not necessarily experienced by the student in this way. This issue indicates the need to strengthen teachers' initial and continuous education in this respect.

Key words: early school leaving, school factors, school composition, school structure, school practices, school climate

\section{Introduction}

As described in the two articles on ESL factors associated with: (1) an individual, their family and social background; and (2) to system characteristics, the phenomenon and process of ESL can be viewed from the perspective of Bronfenbrenner's (1996) ecological systems theory of human development. Bronfenbrenner recognised that many different levels of environmental influence exist and impact one's development. He identified five environmental systems with which individuals interact: the microsystem (i.e. people and institutions in the immediate surroundings - family, peers, school), the mesosystem (i.e. interconnections between settings in which the child participates, e.g. home-school relations), the exosystem (processes and settings with an indirect influence on the individual, e.g. the neighbourhood-community context, education system, social welfare), the macrosystem (i.e. cultural influences) and the cronosystem (i.e. events and changes over time) (see Figure 9). This multidimensional framework presents the basis for understanding risk and protective ESL factors and the multifaceted nature of ESL. In the present article, we look in particular at one specific setting within the microsystem - the school - and review the scientific literature examining its impact on ESL. 


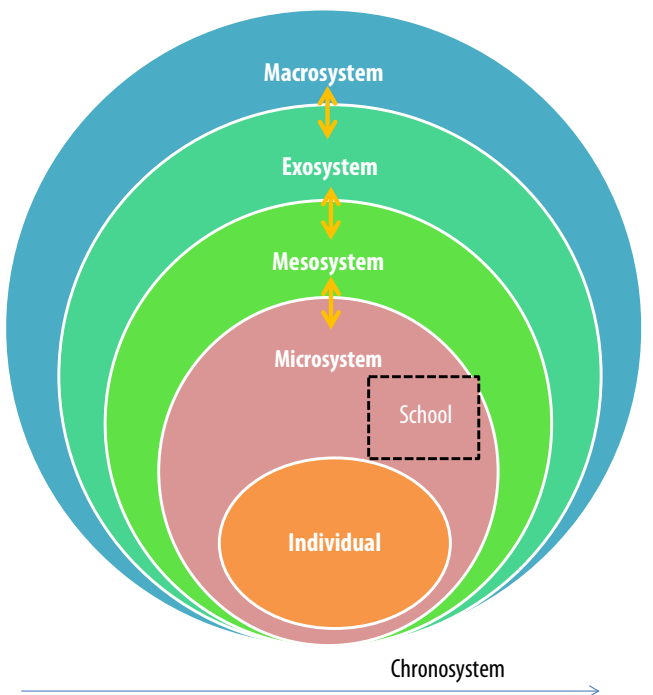

Figure 9. Bronfenbrenner's model of human development. The black rectangle constitutes the focus of the article.

Early studies on ESL mostly considered risk or predictive ESL factors within the individual and their family (see e.g. Ensminger \& Slusarcick, 1992; Barclay \& Doll, 2001 for studies in the period 1950-1970). Later studies revealed ESL to be a process without any one individual cause and may already start in primary school (e.g. Alexander, Entwisle, \& Horsey, 1997; McGarr, 2010) or even as early as the toddlers years (e.g. Jimerson, Egeland, Sroufe, \& Carlson, 2000). A considerable amount was known about how the individual's characteristics and their specific background affected the ESL process, yet much less was known about the influences of the school. But as understanding grew that ESL is a complex phenomenon entailing predictors from multiple levels of the individual's ecology, in the last few decades empirical and review studies have expanded to also include other levels and other settings from the microsystem level, for instance the school (i.e. school or institutional factors; for example, see Audas \& Willms, 2001; Janosz, LeBlanc, Boulerice, \& Tremblay, 1997; Knesting, 2008; Lee \& Burkham, 2003).

Several factors within schools were recognised as playing a role in ESL, with some $20 \%$ of the variability in student outcomes explained by the characteristics of the schools students attend (Rumberger \& Lim, 2008). Many studies are based on multi-level datasets (i.e. samples of students within 
schools within countries/districts) that enable researchers to disentangle student-level and school-level effects. However, establishing a causal relationship between the variable of interest and ESL remains problematic. School factors belong to different levels of the school environment (the student in the classroom, the school buildings, the school district etc.) and the ways these levels interact also impact a student's development (Eccles, 2004).

Different classifications of school (education institution) factors exist:

- $\quad$ school composition (e.g. SES intake); structure (e.g. size, sector and location); resources (e.g. physical, financial and human resources); and practices (e.g. instructional practices) (Rumberger \& Lim, 2008);

- $\quad$ school structure and resources; school practices (Lyche, 2010);

- structural characteristics (e.g. composition of children/students, staff characteristics) and mediating factors (e.g. educators' beliefs and expectations, relationships) (Hasselhorn, Andresen, Becker, Betz, Leuzinger-Bohleber, \& Schmid, 2015).

In this article, we consider the first of these classifications and aim to review and demonstrate the variety of classroom/school factors that may contribute to becoming an ESLer. The article reviews empirical research in the field.

\section{Methodology}

To conduct the scientific literature review, relevant publications were identified by using computerised searches in the Arizona State University Library search engine (including databases such as e.g. PsycINFO, Academic Search Premier (EBSCOhost), ERIC (Proquest), JSTOR Arts and Sciences, ProQuest, SAGE Premier, Science Direct) and other online resources (e.g. ResearchGate, institution or project webpages). We used the following key words "early school leaving", "drop out" AND "school factors/precursors/ determinants", "institutional factors", "curriculum", "pedagogy", "school composition", "school resources", "school practices", "teacher characteristics", "metaanalysis" etc. We then examined references cited in the articles (i.e., "backward search" procedures). Original scientific articles and monographs together with reports by or for the European Commission and the OECD are considered. 


\section{The impact of school composition on ESL}

School composition or the characteristics of the student body are one of the most examined school factors concerning ESL and achievement. This means the characteristics of students as a whole can influence a student over and above the effect of their individual characteristics (Rumberger \& Lim, 2008). In the literature review conducted by these authors, the following indicators of school demographics are identified as having a direct effect on ESL: mean SES, the share of at-risk students (e.g. poor grades, truancy, discipline problems, grade retention), the share of racial or linguistic minorities, the share of high-mobility students (those changing schools or residences) and the share of students from single-parent families (or other family composition alternatives). Traag and van der Velden (2008) also found a large percentage of students from ethnic minorities in school increase the risk for some groups of ESLers (i.e. without a lower secondary diploma) after controlling for the individual's minority background; in general, a $10 \%$ drop in the share of students with a minority background decreased the risk of ESL by $13 \%$. For other groups of ESLers (i.e. with a lower secondary diploma; in an apprenticeship programme), the share of minority students from ethnic minorities in a school had no effect on the risk of ESL. McNeal (1997) also found the percentage of minorities affecting the chances of ESL. A study in Ireland found the effect of the school's socio-economic composition - schools with more students from disadvantaged backgrounds had higher ESL rates, over and above individual student characteristics (Houses of the Oireachtas, 2010).

It is important to note that some studies indicate that, after accounting for several other school characteristics (e.g. school size, climate, resources, student-teacher relations), mean SES and other composition variables no longer have a direct effect on ESL (see, for example, Lee \& Burkam, 2003; Rumberger \& Palardy, 2005). This shows that the effect of school composition is mediated through other variables. Moreover, different structural and organisational characteristics of a school are likely to appear together (Lee \& Burkham, 2003). On a similar note, Palardy (2013) controlled for differences in student background, peer influences, and school inputs and practices and found no differences in high-school graduation probability between low and high SES schools. 


\section{The impact of school structure on ESL}

In this section, we examine the effects of the school characteristic of size, sector (public or private), location (urban or rural) and tracks provided (academic and other lower levels). The sector (public or private) of the school was examined in Rumberger and Rim's literature review (2008). Of the 63 analyses treated, no relationship was found between public-private (in some cases only Catholic schools were considered) school and ESL rates in middle school, but in high school ESL rates were generally lower in Catholic schools (in some studies the effect could be attributed to school practices). As the authors highlight, it is common for students from private schools to transfer to a public school instead of or before leaving school, thereby 'inflating' ESL rates in public schools. In another study, the private/public aspect of a school was found to be unrelated to ESL rates after controlling for students' background and behaviour (Lee \& Burkham, 2003). This finding is also supported by the OECD (2011) which examined the issue of private and public schools relative to achievement in the PISA study. They concluded that students in private schools do indeed perform better in the PISA assessment than students in public schools, yet when the socioeconomic context is similar students in public and private schools tend to do equally well. Moreover, "countries with a larger share of private schools do not perform better in PISA" (p. 1).

In relation to the location of the school, the relationship between the urbanisation of the municipality within which the school is located and ESL is not straightforward. For some groups of ESLers (i.e. those without a lower secondary diploma), an above-average level of urbanisation (high or very high) increased the risk for ESL, and in lowly urbanised areas the chances of ESL dropped, while in other groups of ESLers the effects were not as pronounced (Traag \& van der Velden, 2008). Rumberger and Lim (2008) identified 12 analyses examining this issue, and the results were mixed; in some studies, being in an urban school increased the risk of ESL, while in others it decreased the risk or the effects were non-significant.

As for school size, the same authors (Rumberger \& Lim, 2008) also found mixed results in their literature review. Out of 12 analyses, 6 found no significant effects, while in 3 students were more likely to drop out of large schools and in 3 other studies ESL was less likely in large schools. The relationship might not be non-linear - a smaller (but not too small) size is generally better (Lee \& Burkham, 2003). As noted by Lee \& Burkham (2003), school size per se is unlikely to directly affect the risk for ESL; it is 
more likely that other school, student and staff characteristics play a role. For example, a small school may have better student-teacher relations, better organisational trust, commitment to common goals, contacts (ibid., namely a better social climate). On the other hand, large schools may offer more curriculum, programme, classes and extracurricular options and benefit students' learning in this respect (Rumberger \& Palardy, 2005).

Although not a typical structural characteristic, the issue of different tracks (in terms of levels, i.e. academic or non-academic) provided in schools has also been examined. Traag (2012) and Traag and van der Velden (2008) found that schools' heterogeneity in terms of the tracks they provided was a significant predictor of ESL. Students in lower secondary education who attended more heterogeneous schools (i.e. also providing a higher track of secondary education) were less at risk of ESL than their counterparts who attended a school which only provided lower secondary tracks. The risk of ESL decreased by $25 \%$. The authors argued this may be a result of a more academic climate. This finding is supported by Lee and Burkham (2003); after accounting for student characteristics, schools with more challenging courses, fewer remedial or non-academic courses were more likely to keep students in school compared to their less 'constrained' counterparts. This means that offering a number of undemanding courses in high school does not keep students in schools.

\section{Resources}

In the literature review by Rumberger and Rim (2008), the effects of different indicators for physical, financial and human resources were observed. These included mean expenditures per pupil, mean teacher salaries, the student-teacher ratio, and the share of teachers with advanced degrees. Overall, relatively few studies found significant effects on ESL. Something similar was observed for students' performance in PISA, TIMSS and PIRLS - namely, shortages of educational resources (instructional materials, computers etc.) did not affect students' average performances greatly (Haahr, Nielsen, Hansen, \& Jakobsen, 2005). Regarding class size, Finn, Gerber and Boyd-Zaharias (2005) found that 4 years of elementary school in a small class (13-17 students) increased the odds of finishing high school by $80 \%$ compared to their full-size-class (22-26 students) counterparts, where the effect was especially prominent among students from low-income homes. Small classes effect academic achievement and a student's social behaviour (Finn, Pannozzo, \& Achilles, 2003). Perhaps this effect mainly holds for 
Western societies because, in relation to class size, the OECD (2012) concluded that reducing class sizes is on its own an insufficient policy measure to improve the performance of education systems (after having examined 55 different countries or economies from around the globe).

\section{Impact of school practices}

School processes and practices are seen as the most promising for understanding and improving school performance and tackling ESL (e.g. teaching practices, a school climate conducive to student engagement and learning, social relationships among students, parents, teachers, and administrators). The studies differed in which specific practices were examined, and how they were measured. We separated the findings into those more related to instruction, curriculum and those more related to social and emotional aspects (i.e. climate).

\section{Instructional practices, curriculum, assessment}

Instruction is a key element of the teaching process that takes two main forms: direct instruction (built around problems with clear, correct answers the teacher provides) and student-centred instruction (teacher facilitating students' own inquiry; see European Commission, 2014). Metaanalysis on learner-centred approaches found significant correlations of all person-centred teacher variables (defined as non-directivity, encouraging learning, encouragement of higher order thinking, adapting to differences, empathy, warmth, genuineness and learner-centred beliefs) with each affective or behavioural student outcome, including ESL (Cornelius-White, 2011), indicating the importance of student- or learner-centred approaches for ESL and ESLers. Finn (1989) also emphasised the quality of instruction that supports student involvement (e.g. classroom discourse as opposed to lecturing; also see McGarr, 2010). On the contrary, Van Klaveren (2011) found the proportion of time teachers spend lecturing in front of the class (compared to a more personal approach) did not (negatively) impact students' achievement.

In a literature review for the European Commission (2014), it was recognised that a flexible and relevant curriculum and its provision are important for keeping students at school. However, too much theory, a complicated, rigid and boring curriculum, programmes based on memorising were seen as the biggest issues in this respect (also see Lee \& Miu-Ling Ip, 2003; 
Rumberger, 2011). Indeed, almost 50\% of the respondents reported that a key reason for ESL was that classes were not interesting and they were bored (Bridgeland, DiIulio, \& Morison, 2006). The ESLers in the interviews mention the need for a more balanced, practical and real-life-based provision of the curriculum, with more physical activities and hands-on approaches (Houses of the Oireachtas, 2010; Lee \& Miu-Ling Ip, 2003; McGarr, 2010). Another important aspect is formative assessment (European Commission, 2014) that evaluates a student's progress and provides feedback to allow for improvement (OECD, 2008).

Moreover, the institutional providing of and encouragement to participate in extracurricular activities may contribute to a student's sense of identification with the school, belonging to the school and may be a primary source of attachment to the school for students who are not as successful academically - in this sense, they may contribute to lower ESL (Finn, 1989).

\section{School climate and disciplinary practices}

Most studies examine the effects of different aspects of the school academic and disciplinary climate, including student-teacher relationships. A literature review (Rumberger \& Lim, 2008) found that the general school climate (e.g. school loyalty and a low level of problem-student behaviour (i.e., fighting, cutting class)) and a strong academic climate (i.e. more students in academic tracks) reduced the likelihood of ESL, while a poor disciplinary climate (e.g. student reports of student disruptions in class or discipline problems in the school) and feeling unsafe increased the chances of ESL (also see Houses of the Oireachtas, 2010). McNeal did not find academic climate (a strong emphasis on academic achievement) as impacting ESL (1997). Positive student-teacher relations also reduced the risk of ESL (Byrne \& Smyth, 2010; Hymel \& Ford, 2014; Lee \& Burkham, 2003). The authoritativeness of teachers and their fairness were identified as important in interviews with ESLers (Lee \& Miu-Ling Ip, 2003). On a similar note, the literature review by Audas and Willms (2001) highlights that ESLers perceived the teacher to be less interested in the students and that perceived disciplinary practices were ineffective, unclear and unfairly applied. Downes (2013a) also identified school expulsion and suspension (usually both happen for non-academic reasons) as problematic in terms of ESL; instead, he proposed a multiplicity of intervention approaches to different ESL prevention issues. Moreover, a climate of teasing and bullying (as reported by students and teachers) increased the percentage of ESLers after controlling 
for the effects of other predictors (e.g. school composition variables, community crime, performance in standardised achievement testing; Cornell, Gregory, Huang, \& Fan, 2013; also see Houses of the Oireachtas. 2010). A lack of emotional support services available to students is also important for the ESL issue (Downes, 2011). Brock (2011) found that teachers' expectations concerning students' ultimate education level and their report on self-efficacy did not predict students' ESL. Based on a review of 800 studies, Hattie (2009) concluded the optimal classroom climate for learning is one based on trust and in which errors are allowed.

Knesting (2008) conducted a qualitative study interviewing students at risk for ESL, their teachers who were identified by the same students as either supportive or unsupportive, and certain other school staff. She also observed the teachers so identified in their classrooms. Those teachers who tried to understand the students' behaviour believed that all students could succeed at school and communicated this (i.e. high expectations and respect), and accepted the students 'as is', were seen by students as supportive and helping them to remain at school. Moreover, every student in the classroom was important to these teachers and they interacted similarly with all students. Teachers who, according to the students, simply do not care (e.g. they did not mind when students left the room, did not ask about homework, did not seem excited about the material they were teaching) were listed as a reason for not liking school. On the school level, the students also mentioned an overemphasis on discipline, control, educational conformity and creating a caring and supportive environment with high expectations for everyone's success (also see Hattie, 2009). The sense that some students were valued more than others (e.g. students with higher grades, successful sportsmen or cheerleaders) was also mentioned (also see Downes, 2013a, b). To sum up, students at risk for ESL need their voices to be heard and valued and require caring and respectful communication with teachers, administrators and other school staff. Interestingly, this climate of respect and caring is often intended or assumed by the adults they assume they are providing it; yet students' reports show that students do not experience it in this way -the question thus arises of how adults express care or respect in order for students to experience it as such. On a similar note, Downes (2013a) found splits in communication between students and teachers (e.g. a fear of asking the teacher questions, grading approaches that may lack transparency, access to the toilet, perceived snobbery) and advocated that students' voices be listened to. Rogers (2016) found the 
following characteristics of teacher are important when working with disengaged students, namely one who: listens to students and involves them in decisions about their learning, has respectful interactions, has high expectations, takes time to get to know a student and their background, interest and strengths, and rarely displays irritation towards a student.

The findings indicate a great need for the professional development of teachers (and school staff) in the areas of conflict resolution and diversity skills so as to enable a classroom disciplinary climate to be established that does not include authoritarian teaching, autocratic and rigid behaviour management, unjustified behaviour undermining a pupil's agency (e.g. being picked on by a teacher), offensive language - all behaviours of teachers reported by students (Downes, 2013a, b). Such experiences are an attitudinal precursor for the risk of ESL, thus a positive classroom and school climate are seen as key protective factors against ESL (Downes, 2013a). Based on analyses of data from PISA, TIMSS and PIRLS, it was concluded that while a positive school climate may be a precondition, it is insufficient for ensuring a strong academic performance and participation among students (Haar et al., 2005).

\section{Conclusion}

Based on the literature reviews in the three articles on ESL factors (individual/family factors and system factors), it is obvious that a variety of factors and influences impact a young person's educational pathway, including the decision to leave school. Explanations that rely solely on the characteristics of students and their families are incomplete; there is mounting evidence that schools exhibit important effects on students' leaving or staying in school (Lee \& Burkham, 2003). Schools and their characteristics, including their teachers and other school staff, can make a real difference in students' ability to remain at school. Concerning school-level factors, relationships with the families' microsystem are also important (i.e. the mesosystem). (Potential) ESLers often describe having experienced contradictions between cultural and familial narratives (home culture) and the institutional narratives (i.e. stories of the school - school culture and structure) as contributing to ESL (Clandinini, 2010; Patterson, Hale, \& Stessman, 2007). However, guidance to schools on how to provide the necessary multi-tiered support frameworks addressing multiple ESL risk factors (rather than interventions targeting single components) and early intervention is needed (Freeman \& Simonsen, 2015). 
To sum up, the specific characteristics of school composition (e.g. mean SES, share of students with a minority/migrant background) were found to impact ESL, but these effects are likely confounded with other school characteristics (e.g. school practices). Something similar could be established for school size and public/private sector. The findings regarding school location (urban/rural) were inconsistent. As stated by Audas and Willms (2001), the effects of school composition and structure are important because they are the main areas attracting governmental attempts to tackle ESL; yet, understanding the impact of schools' policies and practices on the risk of ESL is important - as these have holding power over individuals.

In relation to school practices, a mismatch between the (provision of the) curriculum and a student's interest and aspirations was a primary factor identified by ESLers (or those at risk). Innovative delivery of the curriculum is warranted - different pedagogic approaches, including a personalised curriculum, the recognition of informal learning, the use of technology, collaborative approaches via outdoor activities, as well as teaching through arts and sports (Rogers, 2016). Embedded (into the more real-life context of other subjects) approaches to teaching Maths and the mother tongue are suggested to increase the relevance and authenticity of the subjects (ibid.). All of these characteristics were also identified in Hattie's (2009) metaanalysis as being relevant for enhancing student learning (e.g. teachers know how to introduce new content knowledge in a way that integrates it with students' prior knowledge, they can relate the current lesson to other subject areas, and they can adapt the lessons according to students' needs). The findings indicate the need to strengthen teacher's initial and continuous education in this respect.

With regard to school climate, caring, supportive and respectful teachers (and other school staff) who believed in the students' ability to succeed at school have a significant impact on students and them staying in school. Often this does not require financial resources or time outside of the classroom; instead, students found important support or discouragement in everyday school activities and interactions. In order to better understand the roles played by schools and teachers in ESL, it is necessary to listen to the voices of the youngsters themselves. Yet, as Downes (2013a) states, such "dialogue with students arguably comes too late in the process and needs systematic expression at a range of earlier stages as part of prevention focus" (p. 346) at the European level (Downes, 2013b). 


\section{References}

Alexander, K. L., Entwisle, D. R., \& Horsey, C. S. (1997). From first grade forward: Early foundations of high school dropout. Sociology of Education, $70(2), 87-107$.

Audas, R., \& Willms, J. D. (2001). Engagement and dropping out of school: A life course perspective. Working Paper for the Applied Research Branch, Strategic Policy, Human Resources Development.

Barclay, J. R., \& Doll, B. (2001). Early prospective studies of the high school dropout. School Psychology Quarterly, 16(4), 357-369.

Bridgeland, J., DiIulio, J., \& Morison (2006). The silent epidemic: Perspectives of high school dropouts, Civic Enterprises, LLC, Washington.

Brock, E. (2011). Who is accountable for high school dropout? A study of the personal, parental, and teacher related factors of elementary students as predictors of high school dropout. Ottawa, Canada: Library and Archives Canada. Retrieved from http://ijecer.net/pfi-depo/vinz/erin.pdf

Bronfenbrenner, U. (1996). The ecology of human development experiments by nature and design. Cambridge, MA: Harvard University Press.

Byrne, D., \& Smyth, E. (2010). No way back? The dynamics of early school leaving. Dublin, Ireland: The Economic and Social Research Institute, The Liffey Press.

Clandinin, D. J., Steeves, P., Li, Y., Mickelson, J. R. Buck, G. Pearce, M., ... Huber, M. (2010). Composing lives: A narrative account into the experiences of youth who left school early. Retrieved from https://www.researchgate. net/publication/265306620_Composing_Lives_A_Narrative_Account_ into_the_Experiences_of_Youth_Who_Left_School_Early_1

Cornelius-White, J. (2007). Learner-centered teacher-student relationships are effective: A meta-analysis. Review of Educational Research, 77(1), 113-143.

Cornell, F., Gregory, A., Huang, F., \& Fan, X. (2013). Perceived prevalence of teasing and bullying predicts high school dropout rates. Journal of Educational Psychology, 105(1), 138-149.

Downes, P. (2011). The neglected shadow: European perspectives on emotional supports for early school leaving prevention. The International Journal of Emotional Education, 3(2), 3-36.

Downes, P. (2013a). Developing a framework and agenda for students' voices in the school system across Europe: From diametric to concentric relational spaces for early school leaving prevention. European Journal of Education, 48(3), 346-362. 
Downes, P. (2013b). Holistic Approach to Early School Leaving Prevention in Europe: Key Strategic Priorities for System Level Development. Keynote presentation, European Commission, EUNEC (European Network of Education Councils), Lithuanian EU Presidency Conference on Early School Leaving, Seimas (Parliament) of the Republic of Lithuania, 17-19 November.

Eccles, J. S. (2004). Schools, academic motivation, and stage-environment fit. In R. Lerner, \& L. Steinberg (Eds), Handbook of adolescent psychology (2nd ed., pp. 125-153). Hoboken, NJ: John Wiley \& Sons.

Ensminger, M. E., \& Slusarcick, A. L. (1992). Paths to high school graduation or dropout: A longitudinal study of a first-grade cohort. Sociology of Education, 65(2), 95-113.

European Commission (2014). Study on the effective use of early childhood education and care in preventing early school leaving: Annex 1. Literature review ( $\mathrm{N}^{\circ}$ EAC/17/2012). Luxembourg: Publications Office of the European Union.

Finn, J. D. (1989). Withdrawing from school. Review of Educational Research, 59(2), 117-142.

Finn, J. D., Gerber, S. B., \& Boyd-Zaharias, J. (2005). Small classes in the early grades, academic achievement, and graduating from high school. Journal of Educational Psychology, 97, 214-223.

Finn, J., Pannozzo, G., \& Achilles, C. (2003). The "why's” of class size: Student behavior in small classes. Review of Educational Research, 73(3), 321-368.

Freeman, J., \& Simonsen, B. (2015). Examining the impact of policy and practice interventions on high school dropout and school completion rates: A systematic review of the literature. Review of Educational Research, 85(2), 205-248.

Haahr, J. H., Nielsen, T. K., Hansen, M. E., \& Jakobsen, S. T. (2005). Explaining Student Performance Evidence from the international PISA, TIMSS and PIRLS surveys. Final report. Taastrup: Danish Technological Institute. Retrieved from https://www.oecd.org/edu/school/programmeforinternationalstudentassessmentpisa/35920726.pdf

Hasselhorn, M., Andresen, S., Becker, B., Betz, T., Leuzinger-Bohleber, M., \& Schmid, J. (2015). Children at risk of poor educational outcomes: In search of a transdisciplinary theoretical framework. Child Indicators Research, $8(2), 425-438$.

Hattie, J. A. C. (2009). Visible learning: A synthesis of 8oo+ meta-analyses on achievement. Oxford, UK: Routledge. 
Houses of the Oireachtas (2010). Staying in Education: A New Way Forward School and Out-of-School Factors Protecting Against Early School Leaving. Joint Committee on Education and Skills, First Report. Retrieved from http://www.oireachtas.ie/documents/committees3othdail/j-educationscience/reports_2008/20100525.pdf

Hymel, S., \& Ford, L. (2014). School completion and academic success: The impact of early social-emotional competence. In: R. E. Tremblay, M. Boivin, R. Peters (eds.), F. Vitaro F. (topic ed.) Encyclopedia on Early Childhood Development [online]. Retrieved from http:// www.child-encyclopedia.com/school-success/according-experts/ school-completion-and-academic-success-impact-early-social

Janosz, M., LeBlanc, M., Boulerice, B., \& Tremblay, R. (1997). Disentangling the weight of school dropout predictors: A test on two longitudinal samples. Journal of Youth and Adolescence, 26(6), 733-762.

Jimerson, S., Egeland, B., Sroufe, L. A., \& Carlson, B. (200o). A prospective longitudinal study of high school dropouts examining multiple predictors across development. Journal of School Psychology, 38(6), 525-549.

Knesting, K. (2008). Students at risk for school dropout: Supporting their persistence. Preventing School Failure: Alternative Education for Children and Youth, 52(4), 3-10.

Lee, F., \& Miu-Ling Ip, F. (2003). Young school dropouts: Levels of influence of different systems. Journal of Youth Studies, 6(1), 89-110.

Lee, V. E., \& Burkam, D. T. (2003). Dropping out of high school: the role of school organization and structure. American Educational Research Journal, 4o(2), 353-393.

Lyche, C. (2010). Taking on the completion challenge: A literature review on policies to prevent dropout and early school leaving. OECD Education Working Papers, 53, OECD Publishing.

McGarr, J. (2010). Early school leaving: An exploration of the factors contributing to school non-completion. Master's thesis, Dublin Institute of Technology.

McNeal, R. B. (1997). High school dropouts: A closer examination of school effects. Social Science Quarterly 78(1), 209-222.

OECD (2008). Assessment for learning: Formative assessment, OECD/CERI International Conference Learning in the 21st century: Research, Innovation and Policy, the Centre for Education Research and Innovation. Paris: CERI.

OECD (2011). Private schools: Who benefits? PISA in Focus, 7, 1-4. 
OECD (2012). How does class size vary around the world? Education Indicators in Focus, 9, 1-4.

Palardy, G. (2013). High school socioeconomic segregation and student attainment. American Educational Research Journal, 50(4), 714-754.

Patterson, J., Hale, D., \& Stessman, M. (2007). Cultural contradictions and school leaving: A case study of an urban high school. The High School Journal, 91(2), 1-15.

Rogers, L. (2016). Disengagement from education. London: Institute of Education Press.

Rumberger, R. W. (2011). Dropping out: Why students drop out of high school and what can be done about it. Cambridge, MA, USA: Harvard University Press.

Rumberger, R. W., \& Palardy, G. J. (2005). Test scores, dropout rates, and transfer rates as alternative indicators of high school performance. American Educational Research Journal, 42(1), 3-42.

Rumberger, R., \& Lim, S. (2008). Why students drop out of school: A review of 25 years of research, California Dropout Research Project Report \#5. Retrieved from http://uchilishteto.org/data/researchreport15.pdf

Traag, T. (2012). Early school-leaving in the Netherlands. A multidisciplinary study of risk and protective factors explaining early school-leaving. The Hague: Statistics Netherlands.

Traag, T., \& van der Velden, R. K. W. (2008). Early school-leaving in the Netherlands. The role of student-, family- and school factors for early school-leaving in lower secondary education. Maastricht: Research Centre for Education and the Labour Market.

Van Klaveren, C. (2011). Lecturing style teaching and student performance. Economics of Education Review, 3o(4), 729-739. 


\section{2 .3}

\section{The Interplay of Factors Contributing to ESL at the System Level}

Maša Vidmar, Tina Rutar Leban and Tina Vršnik Perše

Synopsis

Aspects of the education system that concern the risk of ESL include the socio-economic segregation of schools, early tracking and grade retention. In that regard, protective aspects are high quality and accessible ECEC and VET. Well-managed transitions between educational levels that reflect a student's changing needs in order to ensure the provision of a developmentally appropriate and engaging context are called for.

\section{Summary}

A relatively recent body of research identifies which factors at the system level contribute to or prevent ESL. The better insights into ESL so far gained show that ESL is a complex issue linked not only to the individual, the family and the school, but also to national policies in the educational, social, health and labour sectors. This article aims to review empirical research regarding ESL system factors with a focus on the education system, but also the labour market.

Evidence shows that the socio-economic segregation of schools and early tracking are linked to a greater risk for ESL. Grade retention is another risk factor, although timing (at the primary or secondary level) and opportunities provided during the retention year play a role. The transition from the primary to secondary level 
is problematic for following aspects: traditional style of academic teaching, lack of relevance of pathways and an excessively rigid curriculum, disconnection from labour market needs, lack of permeability between pathways (academic, technical, vocational). Together with the disruption in social relationships with adults, changes occur in the secondary school context that are developmentally less appropriate for early adolescents and may lead to disengagement and ESL. Thus, the school needs to adapt to a student's increasing maturity and changing emotional, cognitive and social needs as they move through the education system. Moreover, access to high quality ECEC and divergent, relevant and high quality VET play the role of protective factors. The need for a coherent and well-balanced education system at all educational levels (i.e. all parts of the education system from preschool to tertiary education fit together well and function synergistically) is also warranted. The education system should be diverse, but not fragmented. Attention to the system blockages and discontinuities across different polices and sectors is needed.

Key words: education system, socio-economic segregation, grade retention, early tracking, ECEC, VET, transitions

\section{Introduction}

As introduced in the two other articles on ESL factors (factors at the level of the individual, the family and social background, school-level factors), these can be viewed within Bronfenbrenner's ecological theory of human development. This theory posits that five environmental systems interact at multiple levels with the individual: the microsystem (i.e. people and institutions in the immediate surroundings - family, peers, school), the mesosystem (i.e. relationships between the microsystems, e.g. home-school relationships), the exosystem (i.e. an indirect influence on the individual, e.g. health, social, media, neighbours), the macrosystem (i.e. cultural influences - attitudes, ideologies) and the chronosystem (i.e. events and changes over time) (Figure 10). In the two abovementioned articles that are related, we focused on the model's inner circles (i.e. the individual and microsystem), whereas in this article we expand the review of ESL risk and protective factors to the outer circle, i.e. the more distant environmental influences located in the exosystem. 


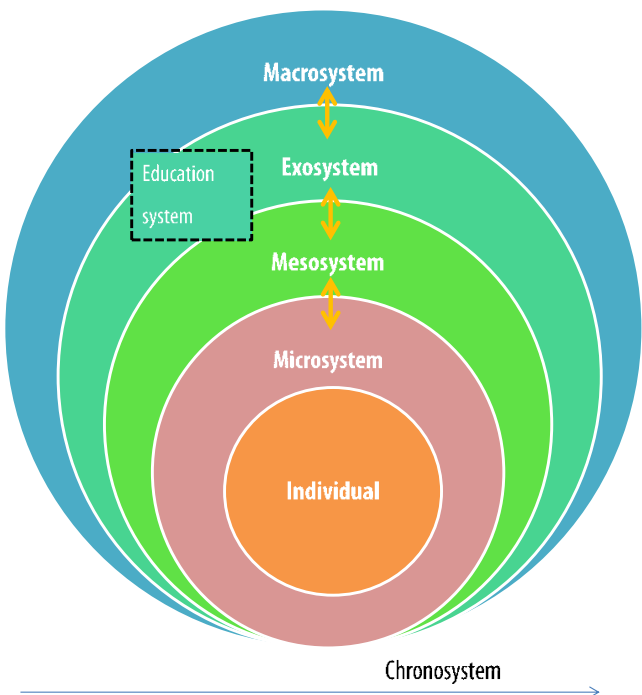

Figure io. Bronfenbrenner's model of human development. The black rectangle constitutes the focus of the article.

Studies on ESL factors and processes have evolved over time. The first wave of studies mostly examined factors within the individual and their family (e.g. Ensminger \& Slusarcick, 1992), with this being followed by a group of studies that also examined school-level factors (e.g. Lee \& Burkham, 2003). The most recent wave of studies recognises that we still only have an incomplete picture of ESL (e.g. De Witte, Nicaise, Lavrijsen, Van Landeghem, Lamote, \& Damme, 2013). Another level has thus been added to the research - the system level (e.g. in the extensive review of ESL factors by Rumberger \& Lim 2008 this level was overlooked). The idea is to understand which national-level policies in different sectors contribute to or prevent ESL, and to highlight the need for coordinated policies. Namely, as insights into ESL increased, it became clear that ESL is a complex issue linked not only to the individual, family and school, but also to national policies. It is not only linked to policies in the education sector, but also those in the social, health and labour sectors, making the issue of ESL exceed the scope of school-level and education-sector policies and thus necessitating cross-sectorial cooperation.

The most recent research on ESL factors at the system level examines how different characteristics of various sectors counter or exacerbate the issue of ESL. This article aims to identify and describe certain features of 
education systems and their relations to ESL, including ECEC and VET (see European Commission/EACEA/Eurydice/Cedefop, 2014). Features and measures emerging in other sectors (e.g. the labour market - see Audas \& Willms, 2002; de Witte et al., 2013; Tumio \& Taylor, 2013) together with inter-sectorial measures are also very important for tackling ESL and should not be overlooked. However, in accordance with the design of the TITA project, the article focuses on features of the education system.

\section{Methodology}

The scientific review was conducted by examining related findings in relevant publications. These were found using computerised searches in the Arizona State University Library search engine (with 650 databases, including, PsycINFO, Academic Search Premier (EBSCOhost), ERIC (Proquest), JSTOR Arts and Sciences, ProQuest, SAGE Premier, Science Direct) and also in other online resources (e.g. ResearchGate, institutional or project webpages). We used the following key words: "early school leaving", "drop out" AND "system-level", "ESL policies", "policy interventions", "education system" "early childhood education system and care", "grade retention", "VET" etc. In the next step, we examined references cited in the articles (i.e., "backward search" procedures). Original scientific articles and monographs as well as reports by or for the European Commission and the OECD are considered.

\section{Education-system-related factors}

Education systems take many different structural forms which can support educational achievement or create obstacles to it (EC, 2014b). In 2011, the EC identified several prevention, intervention and compensation system-level policies addressing ESL. Prevention measures are, e.g. good quality ECEC, prolongation of compulsory education, desegregation policies, systematic language support, and increasing the permeability or flexibility of educational pathways. Intervention measures include early warning systems, enhancing the involvement of parents, networking with actors outside school, teacher education, student-focused strategies, financial support. Compensation measures are e.g. second-chance programmes or recognition of prior learning. In a literature review (EC, 2014b), the following education system factors were identified: educational differentiation, length of compulsory schools, school segregation, investing in education, 
availability and quality of ECEC, curriculum, working conditions (e.g. salaries), teacher-student ratio etc. (also see Bridgeland, Dilulio, \& Morison, 2006). In the present article, we review the following ESL education system factors: grade retention, socio-economic segregation of schools, early tracking, ECEC, transition to (upper) secondary education and VET, all of which are also highlighted in the European Commission/EACEA/ Eurydice/Cedefop report (2014) and other review articles (e.g. EC, 2014b; Jimerson, Anderson, \& Whipple, 2002).

\section{Grade retention}

Grade retention means a student is held back a year (i.e. repeats a year) due to their lack of progress, with this year giving them an opportunity to acquire the knowledge they need to continue schooling (European Commission/ EACEA/Eurydice/Cedefop, 2014). The EACEA/Eurydice study (2011) showed that, even though grade retention is possible in most countries with similar basic regulation (restrictions), practices vary greatly between countries; in some countries, the rates are very low $(<3 \%)$ while in others they are very high (around 30\%, e.g. Spain, France, Luxembourg). Similar grade retention rates were found 3 years later (European Commission/EACEA/ Eurydice/Cedefop, 2014). It seems that grade retention is more common in countries where the view that this may benefit the student still prevails among teaching staff, the education community and parents (EACEA/ Eurydice, 2011).

However, this assumption has been challenged in many studies. Janosz, LeBlanc, Boulerice, and Tremblay (1997) followed two samples of adolescents and found that grade retention significantly increased the risks of ESL in both samples. Roderick (1994) and Alexander, Entwisle and Horsey (1997) obtained similar results. Cairns, Cairns and Neckerman (1989) established a clear relationship between ESL and grade retention (i.e. students who were 1 to 3 years older than their peers in seventh grade were more likely to leave school within the next 4 years). This effect was more pronounced for Caucasian students than their African-American counterparts (ibid.). Jimerson's (2001) metaanalysis of 20 studies showed no clear benefits of retaining students in grades for their academic, social-emotional or behavioural outcomes. When comparing retained students with a matched control group, 16 studies $(80 \%)$ concluded that grade retention is ineffective (either nonsignificant or negative effects were found). The author also emphasised that, despite some positive short-term effects of grade 
retention for certain outcomes, the longitudinal studies show a strikingly close link between grade retention and ESL. In fact, another review study examined 17 studies and determined grade retention was one of the most powerful predictors of ESL (Jimerson et al. 2002). Moreover, grade retention was perceived to be the most stressful life event by sixth-grade students when asked to rate the stressfulness of 20 different life events (Anderson, Jimerson, \& Whipple, 2005). A comparison of students who were retained and then subsequently became ESLers with those who were retained and then managed to finish high school showed that early socio-emotional and behavioural characteristics as well as maternal education and academic achievement distinguish the two groups of retained students (Jimerson, Ferguson, Whipple, Anderson, \& Dalton, 2002). Early attention to a student's social-emotional competencies is thus warranted. A more recent study showed that grade retention in eighth grade significantly increased the probability of dropping out of high school. However, retention in sixth grade did not affect the likelihood of completing high school and twothirds of these students were able to catch up with the original cohort within 2 years (Jacob \& Lefgren, 2009). Interestingly, authors have found no impact of grade retention in eighth grade for those who were sent to 'transition centres' rather than remaining in school. Their findings offer some important insights into grade-retention policies regarding the timing of the retention as well as opportunities provided during the retention year.

\section{Socio-economic segregation of schools}

The segregation of schools refers to the accumulation of students from disadvantaged backgrounds in certain schools (European Commission, 2011). The socio-economic segregation of schools in the education system means there are large disparities between schools in their mean SES, i.e. in the composition of the student body at a particular school in terms of SES. Socio-economic segregation occurs for different reasons. It can be due to the selection made within the education system (e.g. students from a disadvantaged background are over-represented in some types of schools) or may result from the tendency of specific social groups to live in certain areas (European Commission/EACEA/Eurydice/Cedefop, 2014).

Socio-economic segregation is the main factor underpinning segregation in European school systems (European Commission, 2011). It has been shown to be problematic in many ways. For example, the socio-economic segregation of schools is closely linked to the issue of (in)equity 
in education as those secondary school systems in which the schools are strongly segregated on average have lower achievement and greater variability in their PISA achievement; social background is a greater obstacle to educational success than in systems with less segregation among schools (OECD, 2008). Further, there is more problem behaviour in schools that have a concentration of socio-economic disadvantage (David, 2011). Another important issue is that the risk of ESL is considerably higher in schools with a low mean SES (Rumberger \& Lim, 2008; Traag \& van der Velden, 2008). Low school SES is often interwoven with other factors like a higher share of students with a minority/migrant background (e.g. OECD, 2008). Palardy (2013) showed there is considerable variation in high school graduation rates among schools within each socio-economic composition (SEC) category of schools (low, medium and high SEC schools). In some low SEC schools, all students complete high school while in others the figure is a low as $50 \%$. However, despite this variation within each category, the graduation rates for high SEC schools were substantially on average higher than for low SEC schools. It should be noted that some studies (e.g. Lee \& Burkam, 2003; Rumberger \& Palardy, 2005) showed that, after accounting for a variety of other school characteristics (e.g. school practices), mean SES no longer had a direct effect on ESL rates.

Some countries apply active desegregation policies aimed at lowering segregation - they want to change the social composition of low SES schools, for example in Bulgaria and Hungary these seek to reduce the segregation of Roma students (European Commission, 2011). The range of mechanisms available for desegregation include, for example: controlling the entry conditions to individual schools, and positive discrimination measures in support of disadvantaged schools (grants, technical assistance, and other additional resources to schools) (ibid.; OECD, 2012). Attempts to increase the social heterogeneity of schools should always be accompanied by measures to ensure school quality (European Commission, 2011).

\section{Early tracking}

Tracking refers to the degree of educational differentiation in the education system - early tracking characterises systems with a high level of education differentiation that forces students to follow clearly defined paths early on in their education (EP, 2014b). Students are tracked into different educational pathways based on their achievement - a common practice 
in many European countries (European Commission/EACEA/Eurydice/ Cedefop, 2014).

As with grade retention, the assumption is that this is beneficial for students' learning - it is assumed that students learn better in a homogenous classroom at the level that is appropriate for their abilities. Yet this becomes problem when there is a mismatch between the track and a student's potential, aspirations and interests (Hattie, 2009). Studies show tracking negatively impacts students assigned to a lower track and reinforces pre-existing inequities (a student's SES matters more for their academic performance; de Witte et al., 2013; Gamoran \& Mare, 1989; OECD, 2012). Courselevel tracking is one factor explaining why the academic achievement gap associated with SES widens during secondary schooling (Caro, Cortina, \& Eccles, 2015). Moreover, it seems that certain student groups (e.g. with a migrant background) tend to be more often tracked in the least academic tracks, possibly preventing them from fully developing their potential (European Commission/EACEA/Eurydice/Cedefop, 2014). The role of the teachers' (low) expectations is also important in early tracking systems (ibid.).

Early tracking holds clear implications for ESL. Placement in the college track (i.e. academic) increases the chances of high school graduation (after controlling for selection factors; Gamoran \& Mare, 1989). The type of vocational emphasis in school chosen when students are aged around 12 to 13 years plays a role in ESL as the selection of a school may limit easy access to the preferred intermediate vocational track and increase the risk of ESL (Beekhoven, \& Dekkers, 2005).

School systems employing early tracking should postpone its use until upper secondary education while strengthening comprehensive schooling; moreover, opportunities to change tracks and provide high curricular standards for students in the different tracks lessen early tracking's detrimental effects (OECD, 2012). Thus, permeable educational pathways are an important system-level protective factor against ESL (EC, 2011; European Commission/EACEA/Eurydice/Cedefop, 2014).

\section{Early childhood education and care}

The importance of high-quality ECEC is strongly emphasised in various EU documents. It is recognised that it brings a range of short- and longterm benefits for both individuals and society (European Commission/ EACEA/Eurydice/Eurostat, 2014). For example, PISA 2015 showed that 
students who attended ECEC in their childhood outperform those who did not, even after accounting for SES (however, somewhere between two- to three-quarters of the advantage is reduced after accounting for students' and schools' SES; OECD, 2017). Generally, across European countries participation in ECEC is high during the year or two before primary education - on average, $93 \%$ children attend ECEC before they start primary education (European Commission/EACEA/Eurydice/Eurostat, 2014).

Tracing ESL back to (non-)participation in high-quality ECEC is a challenging task. The quality of early caregiving has been shown to be linked to ESL (Jimerson, Egeland, Sroufe, \& Carlson, 200o). In a study carried out by the Public Policy and Management Institute (EC, 2014a), based on a literature review and case studies it was concluded that "in the profiles of pupils who are defined as ESLers and underachievers we see the absence of the very dispositions and skills that are laid down in high-quality ECEC settings" (p. 76). This indicates that high-quality ECEC is a protective factor against ESL, particularly for migrant and minority students (EC, 2012; OECD, 2017).

\section{Transition to (upper) secondary education}

A well-managed transition process from the primary to secondary level, from the lower to upper secondary level, and from school to work are all factors helping to cut the ESL (European Commission/EACEA/Eurydice/ Cedefop, 2014). However, research indicates this is now always the case, and in particular the following drawbacks of transition to upper secondary level are mentioned: traditional style of academic teaching, lack of relevance of pathways and excessively rigid curriculum, disconnection from labour market needs, lack of permeability between pathways (academic, technical, vocational) (ibid.). Smoothing the transition from primary to post-primary level was also one of the key themes raised in interviews with high-risk ESL groups (e.g. people with special educational needs, travellers) and parents of ESLers (Houses of the Oireachtas, 2010).

Other researchers have also problematized the transition to secondary education and the developmental inappropriateness of the secondary school context (e.g. Eccles, 2004). In her model, Eccles argued that the emotional, cognitive and social needs and personal goals of individuals change as they mature. The transition from primary to secondary level needs to reflect these changes and provide a developmentally appropriate context that will continue to motivate and engage students; she called this stage-environment 
fit. The author argued that the extent to which this does not happen leads to the first psychological and later physical disengagement from school, which ultimately is what ESL represents. She emphasised the following discrepancies that are especially problematic in early adolescence (coinciding with the transition to the secondary level in many countries): at this age, environmental changes bring a greater emphasis on competition, social comparison, opportunities for close student-teacher relationships are disrupted and academic work is not in line with the increasing cognitive sophistication, diverse life experiences and identity and autonomy needs of adolescents with all of these potentially decreasing motivation and increasing disengagement. On a similar note, it was recognised that adolescents' growing need for autonomy and participation in decision-making as well as their continuing need for strong social support and trusting relationships with adults is not matched in the transition to secondary education, leading them to turn away from school and adults in the school (Eccles, Lord, Roeser, \& Jozefowicz, 1997). Even though it may appear that these issues take place at the school level (rather than system level), the system can in fact provide strong support to help make the transitions smoother (e.g. by allowing or ensuring continuity in student-teacher relationships between levels).

\section{Vocational education and training (VET)}

ESL is more common in vocational routes (partly due to the overlap with lower social background and academic weakness; NESEE, 2010). Despite this, VET is recognised for holding the potential to attract, retain and reintegrate young people by bringing them back into education and training - it can provide a re-entry point or alternative pathway (European Commission/EACEA/Eurydice/Cedefop, 2014). Understanding ESL from VET can help develop this potential of VET by addressing e.g. the lack of relevance of the curriculum, lack of flexibility, inappropriate pedagogy and young people's labour market aspirations (NESSE, 2010).

The available data show that countries with a relatively weak VET system tend to have higher levels of ESL (ibid.; NESEE, 2010). Countries have adopted many different approaches concerning ESL from VET, but a feature they all share is their awareness of the need to allow VET students to create their own, individual paths. The report identified a student-centred, individualised approach to learning (e.g. through guidance, mentoring, individual learning plans or case management) and a competence-based approach as key aspects (ibid.; also see Rogers, 2016). 
Moreover, VET must be high in both quality and status, and lead to recognisable qualifications as well as match opportunities available in the job market (NESSE, 2010).

\section{Well-balanced education systems}

At a more general, holistic level, researchers have identified so-called well-balanced (EP, 2014a) or consistent education systems (Fthenakis, 2014) as vital characteristics of the education system as a whole. This refers to the characteristic that all parts of the education system from ISCED o to ISCED $6 / 7$ fit together well and function in synergy. Well-balanced education systems have four dimensions: efficiency (every part of the system reinforces the results of the other parts), equity (conditions for the success of one sub-group are not allowed to damage the prospects of another sub-group), cohesion (co-responsibility of stakeholders across the education system) and representativeness (the diversity of pupils is reflected by the diversity of staff and policymakers) (EP, 2014a). The consistency of education systems (Fthenakis, 2014) refers to consistency in the theoretical basis, pedagogical principles and values, educational goals and organisation of the learning process. In EP (2014a), this is called pedagogical and professional continuity (quality of programmes and staff), curriculum continuity and structure continuity (transition between levels). According to these authors, the education system should be diverse (in terms of types of educational tracks, teaching styles etc.), but not fragmented.

\section{Conclusion}

Education policies may be conducive to learning for all learners, including those who struggle at school as a result of different factors, and thereby play a role in preventing or reducing ESL (e.g. high-quality ECEC). On the contrary, some features of the education system have a negative impact on ESL (e.g. grade retention). However, other sectors also play a role, e.g. the labour market and a favourable socio-economic environment (economic growth, the fight against poverty, effective integration strategies for newly arrived immigrants; see de Witte et al., 2013). For example, the labour market can act as 'pull' and/or 'push' factors in the ESL process; a high level of employment opportunities (including regional or seasonal jobs) acts as a 'pull' factor and can stimulate young people to leave school early in order to become financially independent or help their family; conversely, high unemployment rates can have similar or reverse effects. When students observe that 
unemployment does not depend on one's qualification they may become more likely to leave school. Yet, if they notice that adults holding qualifications experience fewer problems in the labour market, they might be more likely to stay at school (de Witte et al., 2013).

The evidence reviewed in this article shows that the socio-economic segregation of schools and early tracking are linked to an increased risk for ESL. Grade retention is another risk factor, although timing (at the primary or secondary level) and opportunities provided during the retention year play a role.

The transition from the primary to secondary level is problematic for the following aspects: traditional style of academic teaching, lack of relevance of pathways and too rigid curriculum, disconnection from labour market needs, lack of permeability between pathways (academic, technical, vocational). Together with the disruption in social relationships with adults, the secondary school context changes in a way that is developmentally less appropriate for early adolescents and may lead to disengagement and ESL. Thus, the school needs to keep pace with students' growing maturity and changing emotional, cognitive and social needs as they move through the education system in order to ensure they are providing an engaging context. Moreover, access to high-quality ECEC and a wide range of relevant and high-quality VET play the role of protective factors. The need for a coherent and well-balanced education system (i.e. all parts of the education system from preschool to tertiary education fit together well and function in synergy) across all educational levels is also warranted. The education system should be diverse, yet not fragmented. Having said this, the results do not imply that it is easy to formulate policies seeking to bring about suitable changes in this area.

To conclude, several points are important when discussing system-level (policy) ESL factors:

- the need for divergent policy proposals reflecting different perceptions of the reasons for ESL (disaffection, non-participation and social exclusion) (Petrušauskaitè, 2010);

- $\quad$ the need for evaluation in terms of the effectiveness and success of the many diverse ESL policies and measures on the national level recently implemented in light of the Europe 2020 headline target to bring ESL rates down to $10 \%$; thus helping to make 
system-related conclusions at the supranational level (Meierkord \& Mascherini, n.d.);

- $\quad$ even though the factors highlighted in the article are important and measures derived from them should be carefully planned, attention to both the measures used in other (non-educational) sectors and to coordinated inter-sectorial actions is justified; namely, system blockages, diametric splits and displacement across different polices and sectors can seriously undermine efforts made (Downes, 2013). As indicated by the EC (2011), "all policies relevant to children and young people should contribute to the strategy against ESL. This concerns especially social policies and support services, employment, youth and integration policies. Every new policy or measure aimed at children, young people, parents or professionals working with children and young people, irrespective of whether related to the formal education system or not, should thus be tested against its contribution to reducing ESL" (pp. 14-15).

\section{References}

Alexander, K. L., Entwisle, D. R., \& Horsey, C. S. (1997). From first grade forward: Early foundations of high school dropout. Sociology of Education, $70(2), 87-107$.

Anderson, G. E., Jimerson, S. R., \& Whipple, A. D. (2005). Student ratings of stressful experiences at home and school: Loss of a parent and grade retention as superlative stressors. Journal of Applied School Psychology, 21(1), 1-20.

Audas, R., \& Willms, J. D. (2002). Engagement and dropping out of school: A life course perspective. Working paper for the Applied Research Branch, Strategic Policy, Human Resources Development. Retrieved from http:// sbisrvntweb.uqac.ca/archivage/15292281.pdf

Beekhoven, S., \& Dekkers, H. (2005). Early school leaving in the lower vocational track: triangulation of qualitative and quantitative data. Adolescence, 40(157), 197-213.

Bridgeland, J., DiIulio, J., \& Morison (2006). The silent epidemic: Perspectives of high school dropouts. Civic Enterprises, LLC, Washington.

Cairns, R. B., Cairns, B. D., \& Neckerman, H. J. (1989). Early school dropout: Configurations and determinants. Child Development, 6o(6), 1437-1452. 
Caro, D.H., Cortina, K.S., \& Eccles, J.S. (2015). Socioeconomic background, education, and labor force outcomes: Evidence from a regional USA sample. British Journal of Sociology of Education, 36(6), 934-957.

David, A. H. (2011). The 'collateral impact' of pupil behaviour and geographically concentrated socio-economic disadvantage. British Journal of Sociology of Education, 31 (3), 261-276.

De Witte, K., Nicaise, I., Lavrijsen, J., Van Landeghem, G., Lamote, C., \& Van Damme, J. (2013). The impact of institutional context, education and labour market policies on early school leaving: A comparative analysis of EU countries. European Journal of Education, 48(3), 331-345.

Eccles, J. S., Lord, S., Roeser, R. W., \& Jozefowicz, D. (1997). The association of school transitions in early adolescence with developmental trajectories through high school. In J. Schulenberg, J. Maggs, \& K. Hurrelmann (Eds.), Health risks and developmental transitions during adolescence (pp. 283-320). New York, NY: Cambridge University Press.

Ensminger, M. E., \& Slusarcick, A. L. (1992). Paths to high school graduation or dropout: A Longitudinal study of a first-grade cohort. Sociology of Education, 65(2), 95-113.

European Commission (2011). Commission staff working paper. Reducing early school leaving. Accompanying document to the proposal for a council recommendation on policies to reduce early school leaving. Retrieved from http://eur-lex.europa.eu/legal-content/EN/TXT/ $\mathrm{PDF} /$ ?uri=CELEX:52011SCoog6\&from $=\mathrm{EN}$

European Commission (2012). Study on educational support for newly arrived migrant children: Final report. Luxembourg: Publications Office of the European Union.

European Commission (2014a). Study on the effective use of early childhood education and care in preventing early school leaving: Final report. ( $\mathrm{N}^{\circ}$ EAC/17/2012). Luxembourg: Publications Office of the European Union.

European Commission (2014b). Study on the effective use of early childhood education and care in preventing early school leaving: Annex 1. Literature review ( $\mathrm{N}^{\circ}$ EAC/17/2012). Luxembourg: Publications Office of the European Union.

European Commission/EACEA/Eurydice/Cedefop (2014). Tackling early leaving from education and training in Europe: Strategies, policies and measures. Eurydice and Cedefop Report. Luxembourg: Publications Office of the European Union. 
European Commission/EACEA/Eurydice/Eurostat (2014). Key data on early childhood education and care in Europe. Eurydice and Eurostat Report. Luxembourg: Publications Office of the European Union.

Fthenakis, W. E. (2014). Changing the paradigm, changing the system: For more justice in preschool education. Key note at 24th EECERA Conference, September 7-10, Crete, Greece.

Gamoran, A., \& Mare, R. (1989). Secondary school tracking and educational inequality: Compensation, reinforcement, or neutrality? The American Journal of Sociology, 94(5), 1146.

Hattie, J. A. C. (2009). Visible learning: A synthesis of 8oo+ meta-analyses on achievement. Oxford, UK: Routledge.

Houses of the Oireachtas (2010). Staying in education: A new way forward school and out-of-school factors protecting against early school leaving. Joint Committee on Education and Skills, First Report. Retrieved from http://www.oireachtas.ie/documents/committees3othdail/j-educationscience/reports_2008/20100525.pdf

Jacob, B., \& Lefgren, L. (2009). The effect of grade retention on high school completion. American Economic Journal: Applied Economics, 1(3), 33-58.

Janosz, M., LeBlanc, M., Boulerice, B., \& Tremblay, R. (1997). Disentangling the weight of school dropout predictors: A test on two longitudinal samples. Journal of Youth and Adolescence, 26(6), 733-762.

Jimerson, S. R. (2001). Meta-analysis of grade retention research: Implications for practice in the 21st century. School Psychology Review, 3o(3), 420-437.

Jimerson, S. R., Anderson, G. E., \& Whipple, A. D. (2002). Winning the battle and losing the war: Examining the relation between grade retention and dropping out of high school. Psychology in the Schools, 39(4), 441-457.

Jimerson, S. R., Ferguson, P., Whipple, A. D., Anderson, G. E., \& Dalton, M. J. (2002). Exploring the association between grade retention and dropout: A longitudinal study examining socio-emotional, behavioral, and achievement characteristics of retained students. The California School Psychologist, 7(1), 51-62.

Jimerson, S., Egeland, B., Sroufe, L. A., \& Carlson, B. (2000). A prospective longitudinal study of high school dropouts examining multiple predictors across development. Journal of School Psychology, 38(6), 525-549.

Lee, V. E., \& Burkam, D. T. (2003). Dropping out of high school: the role of school organization and structure. American Educational Research Journal, 4o(2), 353-393. 
Meierkord, A., \& Mascherini, M. (n.d.) Preventing and re-integrating early school leavers - a meta evaluation of policies implemented in 7 European member states. European Foundation for the Improvement of Living and Working Conditions (EUROFOUND), Dublin, Ireland. Retrieved from http://www.umdcipe.org/conferences/EducationEvaluationItaly/ COMPLETE_PAPERS/Meierkord/Meierkord_paper.pdf

NESSE (2010). Early school leaving: Lessons from research for policy makers. European Commission.

OECD (2008). 10 steps to equity in education. Policy brief. Retrieved from http:// www.oecd.org/education/school/39989494.pdf

OECD (2012). Equity and quality in education: Supporting disadvantaged students and schools. Paris: OECD. Retrieved from http://www.oecd.org/edu/ school/50293148.pdf

OECD (2017). Attendance in early childhoodeducation and care programmes and academic proficiencies at age 15. Lessons from PISA. retrieved from http:// www.oecd.org/officialdocuments/publicdisplaydocumentpdf/?cote=EDU/ EDPC/RD(2017)9\&docLanguage=En

Petrušauskaitè, V. (2010). Dropping out of school - an issue of disaffection, non-participation or social exclusion? Analysing school policies towards Roma school children in Lithuania. Ethnicity Studies, 201o(1-2).

Roderick, M. (1994). Grade retention and school dropout: investigating the association. American Educational Research Journal, 31(4), 729-59.

Rogers, L. (2016). Disengagement from education. London: Institute of Education Press.

Rumberger, R., \& Lim, S. (2008). Why students drop out of school: a review of 25 years of research. California Dropout Research Project Report \#5. Retrieved from http://uchilishteto.org/data/researchreport15.pdf

Rumberger, R.W., \& Palardy, G. J. (2005). Test scores, dropout rates, and transfer rates as alternative indicators of high school performance. American Educational Research Journal, 41, 3-42.

Traag, T., \& van der Velden, R. K. W. (2008). Early school-leaving in the Netherlands. The role of student-, family- and school factors for early school-leaving in lower secondary education. Maastricht: Research Centre for Education and the Labour Market.

Tumino, A., \& Taylor, M. (2015) The impact of local labour market conditions on school leaving decisions. Working paper series from Institute for Social and Economic Research, 2015(14), 1-38. Retrieved from https://www.sheffield.ac.uk/polopoly_fs/1.67957o!/file/F2_2_Tumino.pdf 


\subsection{4}

\section{Contextualising Early School Leaving with PISA Results}

Mojca Štraus

\section{Synopsis}

Longitudinal studies of students which follow them from their initial participation in the PISA study at age 15 clearly show that the strongest predictor of students' early school leaving (ESL) is their achievement in the PISA test. This achievement is a significant predictor of ESL, even after controlling for students' SES. These data show that strong competencies can help overcome the effects of disadvantages.

\section{Summary}

In the paper, a literature review is conducted on studies that have addressed the issue of early school leaving (ESL) by utilising the PISA data and results. Students struggling with school are prone to ESL and students showing low achievement at the end of compulsory education are especially at risk of ESL. The PISA data offer quality indicators on student achievement together with indicators on the background characteristics of students and the schools in which they learn, from which the risk factors of ESL are possibly identified.

Although the number of studies of ESL based on the PISA data found in our literature search was not extensive, there was a pattern in their findings. The key finding is that scores in the PISA achievement test are shown to be the strongest predictor of ESL. The strength of this factor remained significant even after controlling for SES, for which 
associations with school achievement are well established. In other words, a significant share of the effect of student achievement on leaving school can be separated from the effect of one's socio-economic background, meaning that strong competencies can help in overcoming the effects of disadvantages on educational success.

Further, the findings of ESL studies based on PISA generally suggest that student-level variables, such as gender, immigrant status, family situation as well as SES, tend to be generally universal across countries and stable over time in predicting ESL. In contrast, only a few studies find school-level effects, with these generally being related to the socio-economic composition of the student body in the school. That is not to say that school does not have an impact on ESL, but only that this impact has not been systematically recognised in the PISA-based studies.

Key words: ESL, detection, low achievement, PISA

\section{Introduction}

Early school leaving (ESL) is an important issue on the educational policy agenda both nationally and internationally. This paper aims to contextualise ESL based on one of the landmark skills assessments, the OECD's PISA. PISA has become an important component of the strategic framework for European cooperation in education and training (ET, 2020). It represents a prominent information source for the Europe 2020 strategy where it is widely used in fields such as literacy, mathematics, early leavers from education and training, low achievers and information and communications technology (ICT) skills (European Commission, 2013). Based on large nationally representative samples, the PISA study has been examining the performance of 15 -year-olds who are still in education in the areas of reading, mathematical and scientific literacy in over 60 countries every 3 years since the year 2000 . The data also include information on students' attitudes and values, school attendance as well as family backgrounds which enables searching for explanations of the differences in their schooling outcomes.

The aim of this paper is to conduct a literature review on studies that have addressed the issue of ESL by utilising the PISA data and results. Using quality indicators on student achievement together with the indicators on the background characteristics of students and schools that are available 
in the PISA data, research may have identified (some of) the risk factors of ESL which may help in preventing or reducing ESL.

\section{Methodology}

The results of this paper stem from literature searches performed using diverse search engines and bibliographical databases, library catalogues and websites (e.g. Google, Google Scholar, ResearchGate, NUK Mrežnik with access to ERIC, Sage, Springer, and others). Key words used in the search entailed different combinations of the terms 'early school leaving/leavers', 'dropping out, drop out, dropouts' together with 'PISA' or 'Programme for International Student Assessment'. Due to language constraints the searches were performed in English. When searching for such studies, the definitions of ESL were not specifically limited. The studies described in the following paragraph might therefore employ different definitions; however, it is considered that these definitions have sufficient elements in common to inform the research on ESL in general. Further, no distinction was made between the terms 'early school leaving' and 'dropping out' so these terms are used interchangeably in this paper.

\section{Longitudinal studies utilising PISA data to contextualise ESL}

The literature search revealed only a few, around 20, peer-reviewed studies directly utilising the PISA data to address ESL. This relatively small number of studies may reflect the fact that it is impossible to directly measure ESL in PISA since the study is cross-sectional and only includes students still in education. Moreover, only a decade's worth of PISA data is available. Nonetheless, in Australia, Canada and Switzerland the PISA student cohorts were surveyed longitudinally with studies following students' educational pathways in the years after the PISA assessment. The main characteristic of these studies is that it was possible to identify ESLers explicitly. Profiles of the ESLers in comparison with other students were also investigated using the achievement and background data collected in the PISA study. The primary findings about contextualising ESL with the PISA study can therefore be drawn from these studies and we first shortly describe these studies and their most important ESL-related findings.

In Canada, the studies were based on the longitudinal Youth in Transition Survey (YITS) with the first cycle in 2000 in which participants aged 15 also participated in PISA and the same young adults were 
then interviewed every 2 years until the age of 21. The studies based on YITS provide an overview of the nature of the associations between students' characteristics at age 15 and their educational outcomes at ages 17, 19 and 21, including for those who left school early. In subsequent cycles, some youth dropped out of school. Bushnik, Barr-Telford and Bussiere (2004) examined characteristics measured at age 15 associated with dropping out of school by the age of 17 . Similar investigations of data from the third cycle in which the YITS youth were aged 19 were conducted by Knighton and Bussiere (2006) and data analyses from the fourth YITS cycle were published in the OECD (2010). In Australia, the PISA student cohorts were incorporated in longitudinally designed surveys named the Longitudinal Survey of Australian Youth (LSAY). In the context of ESL, Marks (2007) studied the PISA 2003/LSAY cohort and Mahuteau and Mavromaras (2014) the PISA 2006/LSAY cohort. Further, in Switzerland a panel study of the PISA 2000 cohort of students was followed up by the Transitions from Education to Employment survey (TREE) through seven annual survey panels between 2001 and 2007, and an eighth one in 2010. ESL-related findings based on TREE data were derived by Bertschy, Cattaneo and Wolter (2008) along with Mueller and Wolter (2011).

The key finding in all these studies is that the strongest predictor of ESL is the PISA achievement score, which is even stronger than the socio-economic background of students. For Australia, using multilevel models Marks (2007) showed that the greatest influence on ESL was student performance in the PISA test and that this effect was almost four times stronger than that of socio-economic background. Mahuteau and Mavromaras (2014) confirmed that, in addition to student (disadvantaged) background, scores in the PISA test also predict early dropout well, but they pointed out that low PISA achievers are likely to accumulate other types of disadvantage that together then emphasise the probability of dropping out. Overall, the main message of these findings is that a significant share of the effect of student achievement on leaving school can be separated from the socio-economic and other background student characteristics, indicating that strong competencies seem able to help in overcoming the effects of disadvantages.

Such findings have also emerged in other countries. Bertschy, Cattaneo and Wolter (2008), although their study was limited to Swiss students in vocational programmes, found that a higher score in PISA, after controlling for SES, language spoken at home, migration status and region 
of residence, significantly predicted the probability of finishing vocational training successfully within 3 years. Other, less successful students changed their initial training place, repeated a year within their training or abandoned it altogether and therefore became vocational ESL students. Mueller and Wolter (2011) also revealed the PISA scores' significance for future educational success by finding an apprenticeship place for Swiss vocational students. However, they took a different approach to analysing the TREE data: they used background student information from PISA to derive predicted scores and then, based on the residuals of the observed scores from the predicted scores, derived definitions of underachievers, overachievers and achieved-as-expected. Their study investigated whether these student groups differed in their probabilities of successfully starting a certifying apprenticeship after completing school. For PISA-underachievers they found a higher probability of either dropping out, repeating a year, changing training or failing the exam in their vocational training compared to students who had achieved as expected in the PISA test but were otherwise similar to underachievers based on their background characteristics. The authors noted that the PISA test scores and their residuals from the expected scores were virtually the only variables in the study that clearly explained the occurrence of problems during apprenticeship training.

The Canadian studies compared the reading proficiency levels of ESL students when they took the PISA test with the levels achieved by students who successfully continued their education. Bushnik, Barr-Telford and Bussiere (2004) found that youth who had dropped out of school by the age 17 or 19 had PISA scores a whole proficiency level ${ }^{1}$ lower in reading literacy than their counterparts who continued education or graduated. Although this result did not control for student background variables, the difference of one proficiency level can be considered comparatively large, and indicates a substantial difference in the nature of reading tasks students can perform. Knighton and Bussiere (2006), after taking the effects of student background into account, further found that the odds of completing high school for a student with PISA 2000 reading scores at Level 2 or below were significantly lower than the odds for a student with scores at Level 3 or above. These results suggest a threshold effect with those at Level 2 and below being at particular risk of not completing school by age 19. However,

The PISA achievement scales are described in hierarchically organised proficiency levels. The PISA 2000 reading scale was divided into five levels, from Level 1 to Level 5, the latter being the highest. Each level describes the content of knowledge and skills students with proficiency at this level generally exhibit. 
these relationships are not deterministic; a substantial proportion of students with PISA scores at or below Level 2 in fact successfully graduated, while at the same time a notable proportion of students with PISA scores at or above Level 3 had not graduated from high school by age 19. Similarly, after adjusting for background factors, the OECD (2010) reported that students in the bottom quartile of the PISA reading scores at age 15 were much more likely to drop out of secondary school than those in the top quartile.

The results of the Canadian studies are in line with the results of the mentioned Australian studies by showing that the strong association between reading proficiency and educational attainment still holds after adjusting for background factors, such as socio-economic and immigrant status. In addition, another Canadian study by Murdoch, Kamanzi and Doray (2011) further showed that PISA scores at age 15 together with social factors more strongly impact access to this educational level than later persistence in this education.

Along with the PISA score, studies have also investigated the effect of other factors on ESL. Some effects of the socio-economic background having a strong effect on ESL, but not stronger than PISA achievement, have already been mentioned. Marks (2007) investigated the impact of attitudinal variables on ESL and found that more positive attitudes to school as well as attitudes to teachers reduced the odds of leaving school. In contrast, students' evaluations of the disciplinary climate in their mathematics classes revealed no impact on school leaving. The study also reported that the inclusion of attitudinal variables had little impact on the effects of other variables. For the school-level measures available in PISA, Marks (2007) found no associations with school leaving in Australia. The author concluded that, consistent with the international literature, this indicates that schools do not have a strong independent influence on school leaving. Yet this is not to say that there are no schools with substantially higher or lower levels of school leaving than expected given their students' characteristics, but only that there are few of such schools and they do not vary in identifiable, systematic ways from other schools (ibid.).

One other study in Europe addressed the issue of explicitly measured ESL by utilising the PISA results. The importance of the PISA achievement for ESL, more specifically for the consequences of ESL, was found by Alphen (2009). The study analysed EU Statistics on Income and Living Conditions (EU-SILC) data for 2005 to 2007 in examining to what extent compositional variation of ESLers can account for cross-national variation 
of their income disadvantage relative to higher educated individuals in 21 EU countries. A country's mean PISA achievement scores were used as one of the indicators of the average quality of available educational resources, together with educational expenditure. Findings showed that the income disadvantage of ESLers is smaller in countries where the average quality of available educational resources is higher. This means that a higher PISA mean score in a country was found to be associated with smaller disadvantages of ESL.

\section{Studies utilising PISA data and intention to leave school as a proxy for ESL}

The studies described so far based their measure of ESL on explicit variables directly indicating whether a student is an ESLer or not. Yet there are other studies that employed other variables as an indication of ESL, for example a student's response as to whether they intend to leave school early obtained from a specifically designed questionnaire. Studies measuring the intention to leave school early were conducted in Ireland (Gillece, Cosgrove, \& Sofronuiou, 2010; JCES, 2010), Switzerland (Eicher, Staerkle, \& Clemence, 2014), Spain (Enguita, Martinez, \& Gomez, 2010) and Italy (Alverini \& Lucidi, 2011). Notably, the results of the Swiss study that collected data at different points in time in students' educational pathways showed that dropout intentions reliably predicted actual dropout 1 year later (Eicher, Staerkle, \& Clemence, 2014). Some of these studies included the PISA test score as a predictor of ESL while others only used the PISA student background information, chiefly the PISA socio-economic and cultural index, in investigations of the ESL risk factors. In the first set of studies, the PISA test score again proved to be an important predictor of ESL. The studies and their findings are described in greater detail below.

Both studies for Ireland (Gillece, Cosgrove, \& Sofronuiou, 2010; JCES, 2010) used PISA 2006 data and achievement in predictions of ESL, measured by an additional national variable indicating whether a student intended to leave school early without completing Grade 12. The studies aimed to identify the individual- and school-level characteristics for students who intended to leave school early, yet by using different approaches. While the JCES (2010) study took the intention to leave school early as an outcome variable, Gillece, Cosgrove and Sofronuiou (2010) used the intention to leave school early as one of the predictors, among other student background characteristics, of their achievement. The latter study found 
that intending to leave school early was significantly associated with both high and low PISA achievement, namely students who intended to leave school early were more than twice as likely to be low mathematics achievers than medium achievers (also high achievers). Therefore, the PISA achievement was again shown to be related with ESL.

Investigations of PISA background variables as factors in students' intentions to leave school early revealed similar results as those studies in which ESL was explicitly measured. The JCES (2010) study found several student-level variables were associated with the intention to leave school early, such as PISA achievement, gender, home educational resources and books in the home, while at the school level only one variable, fee waiver, was found to be a significant characteristic. However, for this variable an interaction with home educational resources was found, suggesting that homes where parents were able to provide higher levels of home educational resources might be operating in a protective manner against student ESL intent in schools where fee waiver rates are high (i.e. with higher concentrations of students from low-income families). This study concluded that, while economic deprivation impacts on ESL, a positive and supportive home educational environment, rather than measures of parental income or education, may be a key factor in protecting against ESL.

From their analysis of PISA 2003 data to investigate the influences of background student characteristics on the process of dropping out of school in Spain, Enguita, Martinez and Gomez (2010) found that Spanish boys have a higher probability of repeating a grade than girls, and that a smaller proportion of boys aspire to obtain a post-compulsory educational degree and are therefore more prone to the risk of ESL. Immigrant students born outside of Spain were found to combine high rates of repetition and particularly low scores in the PISA test and therefore being even more prone to the risk of ESL. At the same time, the children of immigrants, who were born in Spain, revealed a similar ESL-risk level as did working-class Spanish students. The study also found that the risk of dropping out is higher for students from non-nuclear families.

Some other interesting findings have been made about associations of attitudinal factors with the intention to leave school early. An Italian longitudinal study by Alverini and Lucidi (2011) used the PISA socio-economic and cultural index as one of the controls in their path-model investigation of the role of students' self-determined motivation in reducing the intention to drop out from high school. The results showed that self-determined 
motivation in students accounted for significant variability in the intention to drop out of high school (i.e. low motivation predicted intention to drop out). Moreover, the intention to drop out seemed to have been more directly affected by self-determined motivation than by school achievement and perceived competence.

In Switzerland, Eicher, Staerkle and Clemence (2014) utilised the TREE study data to investigate associations of attitudinal factors with ESL. More specifically, they investigated longitudinally perceived stress and optimism as predictors of dropout intentions over a period of 4 years while controlling for educational performance in PISA, SES and immigrant status. The study found that both average levels of stress and optimism as well as annually varying levels of stress and optimism affected dropout intentions. In other words, when controlling for the average level of stress and optimism at the personal level, more stress and less optimism than usual led to higher dropout intentions. The authors concluded that dropout intentions are not stable over the student's time in education and may thus be influenced by periods of stress experienced by students.

\section{Studies utilising a low PISA achievement score as a proxy for ESL}

A third set of studies emerged from our literature review of research on ESL within the PISA context. The overriding characteristic of this set of studies is that, instead of employing explicit data on whether a subject is an ESLer or whether they intend to leave school early, low achievement in the PISA test was used as a proxy measurement for the risk of ESL. More specifically, a student was defined at risk of ESL in these studies if they had achieved a score below Level 2 in the PISA scale for reading (or another domain). Most of such studies found in our literature review were conducted for cohorts of Spanish students participating in PISA. This is not surprising since in Spain school failure has been one of the principal problems of the education system in recent decades (Guio Jaimes \& Choi de Mendizabal, 2014). By using several cycles of PISA data, two studies (Guio Jaimes \& Choi de Mendizabal, 2014; Guio Jaimes, Choi de Mendizabal, \& Escardibul Ferra, 2015) found that personal and most household characteristics with a significant influence on the risk of school failure (i.e. PISA achievement) proved to be particularly stable in this influence over time while most of the school-level characteristics were found not to be stable. This again indicates it is no easy task to reveal the effect of school-level variables on ESL. 
In the study by Guio Jaimes, Choi de Mendizabal and Escardibul Ferra (2015) an interesting perspective was introduced, namely that the dynamics of the labour market could impact academic performance and students' decisions to remain at school. The study established that the youth unemployment rate was positively related with the risk of school failure and early dropout from school. The authors concluded that while the youth unemployment rate (which is highly correlated with the adult unemployment rate) could have a two-way effect on ESL, the first being forcing students to abandon the school system to enter the labour market to help support their families and the second discouraging them to do so due to the lack of labour opportunities for them, the first effect appeared to be stronger.

Two studies by Boada, Herrera, Mas, Minarro, Olivella and Riudor (2011) and by García-Pérez, Hidalgo-Hidalgo and Robles-Zurita (2014) used PISA 2006 and PISA 2009 data, respectively, to analyse characteristics of Spanish students at risk of ESL based on low PISA achievement and investigated the associations between this risk and grade repetition. The first study reported that skills in reading and mathematics significantly affected the likelihood of repetition. The second study stated that grade retention has a negative impact on students' achievement. The authors concluded that repetition may not be the right policy to help weak students and should be combined with other practices to help in closing learning gaps, e.g. remedial education or ECEC interventions.

NESSE (2010) commissioned an independent expert report on ESL in Europe in which the causes, consequences and possible remedies for ESL were examined. To a small extent the report used PISA analyses, conducted by Willms (2006), on whose basis the report concluded there is an important school composition effect on ESL. School composition effect refers to the ways the characteristics of the student body as a whole, especially its social make-up, affect school processes and influence the achievement of students, even after taking individual students' SES into account. The report elaborates that a young person - with the same mix of dis/advantages and the same history of school achievement - will leave one school early but would not leave another school early. Within the context of OECD work, a literature review by Lyche (2010) on international research in the ESL field in OECD countries incorporated the PISA results by investigating factors associated with low achievement. It also concluded that PISA shows a clear advantage when attending schools where students come from a more advantaged socio-economic background. These two studies seem to be in 
contrast with the previously mentioned findings of Marks (2007) and others that school-level measures showed no association with ESL. However, this contrast may stem from the fact the first studies used an explicit measure of ESL while the above-mentioned studies employed an individual's low PISA achievement as a proxy for ESL. The second set of studies therefore reveals the well-known finding of the school composition effect on an individual's achievement but which does not seem to transfer easily to cases where ESL is measured explicitly.

\section{Conclusions}

In the paper we have reviewed studies addressing the issue of ESL by utilising PISA data and results. Although the number of such studies we found was not large, a pattern emerges in their findings. The most important finding from our literature review is that students' achievement shown in the PISA test has a powerful impact on their propensity to leave school early. This was clearly shown by the studies assessing ESL through follow-up longitudinal surveys of the PISA student cohorts. This means that strong competencies are important for students' further (educational) life. The strength of the achievement as a factor in risk of ESL remained significant even after controlling for SES, for which associations with school achievement are well established. Further, among the factors analysed, the impact showed to be the strongest, even stronger than the impact of SES. A significant share of the effect of student achievement on leaving school can therefore be separated from the effect of socio-economic background, indicating that strong competencies can help in overcoming the effects of disadvantages.

Studies have generally found common sets of student-level variables associated with (the risk of) ESL that, in some studies, also proved to be stable in time. Such factors tend to be social factors such as gender, parental education, SES, immigrant status, previous schooling and, as mentioned, PISA scores. At the same time, scarce findings indicated any school-level impact (e.g. average SES in the school); in Ireland, JCES (2010) found a fee waiver to be significantly associated with the intention to leave school early while Willms (2006) found that school-compositional effect has an influence on an individual student's achievement. But when ESL was measured explicitly, Marks (2007) did not find a school effect. This may seem contradictory, but it shows that even though there are schools with substantially higher or lower levels of school leaving than expected given their students' 
achievement and other characteristics, these schools do not vary in identifiable, systematic ways from other schools in terms of an observable association with ESL rates. This may actually be seen as showing that there is room for schools to exert a positive effect on ESL. Some studies pointed out that school processes indicate possible remedies in the sense that positive values of student-level attitudinal variables to school may help in reducing the odds of ESL when combined with practices to help close learning gaps early.

\section{References}

Alivernini, F., \& Lucidi, F. (2011). Relationship between social context, self-efficacy, motivation, academic achievement, and intention to drop out of high school: A longitudinal study. The Journal of Educational Research, 104(4), 241-252.

Alphen, S. van (2009). The educational quality of early school leavers and the cross-national variation of their income disadvantage. Educational Research and Evaluation: An International Journal on Theory and Practice, 15(6), 543-560.

Bertschy, K., Cattaneo, M. A., \& Wolter, S. C. (2008). What happened to the PISA 2000 participants five years later? IZA Discussion Paper No. 3323. Institute for the Study of Labor, Bonn, Germany. Retrieved from http:// $\mathrm{ftp}$.iza.org/dp3323.pdf

Boada, C., Herrera, D., Mas, E., Minarro, E., Olivella, M., \& Riudor, X. (2011). Risk of school failure in Catalonia. Report no. 26. Economic, Social and Work Council of Catalonia (CTESC), Barcelona, Spain. Retrieved from http://www.ctesc.cat/doc/doc_18992942_1.pdf

Bushnik, T., Barr-Telford, L., \& Bussière, P. (2004). In and out of high school: First results from the second cycle of the Youth in Transition Survey. Statistics Canada Research papers -Education, skills and learning, Catalogue no. 81-595-MIE - No. 014. Statistics Canada and Human Resources and Skills Development Canada, Ottawa.

Eicher, V., Staerkle, C., \& Clemence, A. (2014). I want to quit education: A longitudinal study of stress and optimism as predictors of school dropout intention. Journal of Adolescence, 37, 1021-1030.

Enguita, M. F., Martinez, L. M., \& Gomez, J. R. (2010). School failure and dropouts in Spain. Social Studies Collection No. 29. The "la Caixa" Foundation, Barcelona, Spain. Retrieved from https:/obrasocial.lacaixa.es/ deployedfiles/obrasocial/Estaticos/pdf/laCaixafoundation/vol29_en.pdf 
European Commission. (2013). PISA 2012: EU performance and first inferences regarding education and training policies in Europe. Executive Summary. Retrieved from http://ec.europa.eu/education/policy/strategic-framework/ doc/pisa2012_en.pdf.

Ferguson, B., Tilleczek, K., Boydell, K., Rummens, J. A., Roth Edney, D., Michaud, J., \& Cote, D. (2005). Early school leavers: Understanding the lived reality of student disengagement from secondary school. Final Report prepared by Community Health Systems Resource Group. The Hospital for Sick Children: Ontario, Canada.

García-Pérez, J. I., Hidalgo-Hidalgo, M., \& Robles-Zurita, J. A. (2014). Does grade retention affect students' achievement? Some evidence from Spain. Applied Economics, 46(12), 1373-1392.

Gilleece, L., Cosgrove, J., \& Sofroniou, N. (2010). Equity in mathematics and science outcomes: Characteristics associated with high and low achievement on PISA 2006 in Ireland. International Journal of Science and Mathematics Education, 8, 475-496.

Guio Jaimes, J. M., \& Choi de Mendizabal, A. (2014). The evolution of school failure risk during the 2000 decade in Spain: Analysis of PISA results with a two-level logistic model. Estudios Sobre Educacion, 26, 33-62.

Guio Jaimes, J. M., Choi de Mendizabal, A., \& Escardibul Ferra, J. O. (2015). The impact of the labor market in educational outcomes in Spain. Retrieved from http://2015.economicsofeducation.com/user/pdfsesiones/222.pdf.

JCES Joint Committee on Education and Skills. (2010). Staying in education: A new way forward. School and out-of-school factors protecting against early school leaving. First Report. Houses of the Oireachtas, Ireland. Retrieved from http://www.oireachtas.ie/documents/committees3othdail/j-educationscience/reports_2008/20100525.pdf.

Knighton, T., \& Bussière, P. (2006). Educational outcomes at age 19 associated with reading ability at age 15 . Research paper - Catalogue no. 81595-MIE - No. 043. Statistics Canada and Human Resources and Skills Development Canada, Ottawa.

Lyche, C. (2010). Taking on the completion challenge: A literature review on policies to prevent dropout and early school leaving. OECD Education Working Papers, No. 53. OECD Publishing. Paris, France.

Mahuteau, S., \& Mavromaras, K. (2014). An analysis of the impact of socioeconomic disadvantage and school quality on the probability of school dropout. Education Economics, 22(4), 389-411. 
Makarova, E., \& Herzog, W. (2013). Hidden school dropout among immigrant students: A cross-sectional study. Intercultural Education, 24(6), 559-572.

Marks, G. N. (2007). Do schools matter for early school leaving? Individual and school influences in Australia, school effectiveness and school improvement. An International Journal of Research, Policy and Practice, 18(4), 429-450.

Mueller, B., \& Wolter, S. C. (2011). The consequences of being different: Statistical discrimination and the school-to-work transition. IZA Discussion Paper No. 5474. Institute for the Study of Labor, Bonn, Germany. Retrived from http://ftp.iza.org/dp5474.pdf

Murdoch, J., Canisius Kamanzi, P., \& Doray, P. (2011). The influence of PISA scores, schooling and social factors on pathways to and within higher education in Canada. Irish Educational Studies, 30(2), 215-235.

NESSE Network of Experts in Social Sciences of Education and Training. (2010). Early school leaving - lessons from research for policy makers. European Commission, Brussels, Belgium.

OECD. (2010). Pathways to success - how knowledge and skills at age 15 shape future lives in Canada. OECD Publishing. Paris, France.

Willms, D. (2006). Learning divides: Ten policy questions about the performance and equity of schools and schooling systems. UNESCO Institute for Statistics working paper No. 5. Unesco Institute for Statistics, Montreal, Canada. 
2.3 selected ESL factors:

the basis for prevention

activities 



\subsection{I}

\section{The Relationship Between Teachers' Teaching Styles, Students' Engagement in School and ESL}

Tina Rutar Leban

\section{Synopsis}

A teacher's teaching style (authoritative, authoritarian and permissive) affects students' experience in school. It can provoke functional or non-functional perceptions of learning, self-efficacy and schoolwork, thus an appropriate teaching style can help prevent early school leaving.

\section{Summary}

Teaching style defines the behaviours or actions teachers exhibit in the teaching process. Moreover, it reflects the beliefs and values teachers hold about the role of the teacher and the learner in the learning exchange (Heimlich \& Norland, 2002). Teaching style is not only the teaching method itself but something larger that relates to the entire teaching-learning exchange, regardless of the environment or content of teaching (Heimlich \& Norland, 2002).

The relationship between teaching styles and early school leaving (ESL) has not been directly studied. But there is varying evidence that teachers' teaching style affects certain factors such as self-efficacy, academic self-image, school-related attitudes, achievements, engagement in school (e.g. Walker, 2009; Wentzel, 2002) that have been shown to be important predictors of ESL (Lan \& Lanthier, 2003). Different studies that analysed teaching styles through the 
framework of parenting styles indicate that teachers' characteristics, similar to parenting behaviours characterised as authoritative (warm and supportive of autonomy as opposed to controlling), were found to be positively related to student motivation and feelings of academic competence (e.g. Moos, 1978; Ryan, Stiller, \& Lynch, 1994; Wentzel, 1997). In addition, some characteristics of the authoritative teaching style (such as warmth, openness, support, supervision etc.) have been shown to help students at risk for ESL stay more engaged in school and thus be less prone to dropping out (Fallu \& Janosz , 2003; Crosnoe, Kirkpatrick Johnson, \& Elder, 2004; Murray \& Malgrem, 2005).

There is empirical evidence that a teacher's teaching style significantly affects the different outcomes of the teaching-learning process in school. What is important for teachers to realise is that their teaching style influences students' perception of school and school work. The development of a teaching style is an ongoing process based on teachers' professional growth and students' characteristics. It is the teacher's responsibility to recurrently analyse their teaching style, reflect on it and implement necessary changes. Constant reflection on one's own teaching practices, classroom activities and problem-solving approaches in the classroom are the basic teaching style monitoring approaches.

Key words: teaching style, teacher-student relationship, school engagement, self-determination, early school leaving

\section{Introduction}

Teachers create specific psychological and behavioural structures within classrooms, which hold consequences for student engagement and learning, and influence students' academic self-image and their attitudes to knowledge and learning (Walker, 2008). Ultimately, they can also influence students' decision to stay in or leave school (Lee \& Breen, 2007; Tyler \& Lofstrom, 2009). The social quality of teacher-student relationships contributes to both the academic and social-emotional development of students (e.g. Gregory \& Weinstein, 2004; Hamre \& Pianta, 2001). Students with caring and supportive interpersonal relationships in school report more positive academic attitudes and values, and greater satisfaction with school. These students also are more academically engaged (Roorda, Koomen, Spilt, \& Oort, 2011). 
These specific psychological and behavioural structures created by teachers within the classroom are commonly defined as teachers' teaching style. Teaching style is referred to as a predilection to teaching behaviour and congruence between an educator's teaching beliefs and their teaching behaviours (Heimlich \& Norland, 1994). Conti (1985; 2004) describes it as persistent and distinct qualities a teacher displays in the classroom. It is also defined as a pervasive quality in an educator's teaching that persists even when the content changes (Fisher \& Fisher, 1979). Teaching style defines behaviours or actions that teachers exhibit in the teaching process. Teaching behaviours reflect the beliefs and values teachers hold about the role of the teacher and the learner in the learning exchange (Heimlich \& Norland, 2002). Teaching style is not only the teaching method itself but something larger that relates to the entire teaching-learning exchange, regardless of the environment or content of teaching (Heimlich \& Norland, 2002).

We can find different typologies of teaching styles in the literature (e.g. Bennett, 1976; Flanders, 1970; Good, 1979). Schultz (1982), for example, stressed the difference between a directive and a non-directive approach to teaching. Grasha (1996) identified five potential approaches/roles of teachers in the classroom (Expert, Formal Authority, Personal Model, Facilitator and Delegator). Deriving from the constructivist view of learning, a "learner-centred approach" has been advocated in the last few decades (Zophy, 1982; McCombs \& Whistler, 1997; Weimer, 2002; Pillay, 2002). Based on the literature on teaching styles, Dupin-Bryant (2004) defines a learner-centred teaching style as responsive, collaborative, problem-centred and democratic in which both students and the teacher decide how, what and when learning occurs. On the other hand, a teacher-centred teaching style is defined as formal, controlled and autocratic in which the teacher directs how, what and when students learn. Behar-Horenstein (2006) defined teaching styles' beliefs across two domains (teacher-centred and student-centred) and four subdomains (methods of instruction, classroom milieu, use of questioning, and use of assessment). Some researchers also tried to compare teaching styles with parenting styles (e.g. Barnas, 2001; Walker, 2009; Wentzel, 2002). They detected the authoritative, authoritarian and permissive teaching styles.

In this article, we focus on the role teachers and their teaching styles play in developing students' self-efficacy, attitude to school work, learning, knowledge and academic achievements which represent potential protective 
factors against ESL (e.g. Battin-Pearson et al., 2000; Lan \& Lanthier, 2003). The relationship between teaching styles and ESL has not been directly studied. But there is varying evidence that the teaching style of teachers affects some dimensions such as self-efficacy, academic self-image, school-related attitudes, achievements, engagement in school (e.g. Walker, 2009; Wentzel, 2002) that have been shown to be important predictors of ESL (Lan \& Lanthier, 2003). Accordingly, emphasising the importance of an appropriate teaching style can help better prevent ESL.

\section{Methodology}

The article is based on a review of the literature entailing searching in the PsycINFO, ERIC, Proquest, Science Direct and Google scholar, Proquest Dissertation \& Theses Global search databases. Key words used in the literature search were predictors for early school leaving, teaching styles, school environment, classroom environment, school performance, school achievements, teachers' beliefs, teachers' behaviours, school dropout etc. For the purposes of this article, we mainly took scientific papers and some online scientific books into consideration.

\section{A parenting style framework for teaching style in the school environment}

As mentioned, some researchers have investigated comparisons between parenting styles and teaching styles (e.g. Barnas, 2001; Walker, 2009; Wentzel, 2002). Parenting styles are constellations of parental attitudes, practices and non-verbal expressions that characterise the nature of parent-child interactions (Darling \& Steinberg, 1993). Contemporary research on parenting styles derives from Baumrind's $(1971,1978)$ studies of family interactions. Based on her observations of parents interacting with preschool children, Baumrind (1967) highlighted two basic dimensions of parenting styles: parental demandingness/undemandingness and parental responsiveness/unresponsiveness. Using combinations of these two parental behaviour dimensions, Baumrind recognised four parenting styles: an authoritarian parenting style - the style of enforcing power (characterised by high demands and unresponsiveness to children's needs, interests, rights), an authoritative parenting style (characterised by a combination of high demands and responsiveness to children's needs, warmth), a permissive parenting style - the style of inefficient control (characterised by low 
demands and responsiveness) and an uninvolved parenting style (characterised by parents' lack of demands and responsiveness) (Baumrind, 1967).

Similarly to research on parenting styles, researchers have focused on dimensions of teachers' demandingness and responsiveness in the classroom, and investigated students' outcomes when different teaching styles were used in the classroom (e.g. Barnas, 2001; Walker, 2009; Wentzel, 2002).

\section{Impact of teaching style on students' learning and social outcomes}

Different studies that analysed teaching styles through the parenting styles framework indicate that teachers' characteristics, similar to those parenting behaviours characterised as authoritative (warm and supportive of autonomy as opposed to controlling), were found to be positively related to student motivation and feelings of academic competence (e.g. Moos, 1978; Ryan, Stiller, \& Lynch, 1994; Wentzel, 1997). Walker (2008), for example, researched students' (12-year-olds) perceived self-efficacy, their readiness for schoolwork and their academic performance in mathematics in classrooms with different teaching styles. Students in the class where the teacher applied the authoritative teaching style (as categorised by observers) made greater achievement gains than their peers who had permissive teachers. They also showed more engagement in school work than their peers who had authoritarian teachers. Similar results were found by Wentzel (2002). Students whose teachers set high academic expectations (a characteristic of authoritarian and authoritative but not permissive teaching styles) obtained better grades and were more interested in school. In contrast, students with teachers who were more critical and negative in their feedback (a characteristic of authoritarian but not authoritative and permissive teaching styles) had worse grades and were less interested in school (Wentzel, 2002). Barnas (2001) observed her own teaching style (teaching students at the university level) during the progress of her career. She perceived her teaching style as progressing from being permissive to authoritarian to authoritative. Her perception and student evaluation indicated that the authoritative teaching style was the most effective in that students were both prepared for class and participated enthusiastically. There is also evidence that students prefer college teachers who possess characteristics consistent with the authoritative style, such as warmth and approachability (e.g. Basow, Phelan, \& Capotosto, 2006; Basow \& Silberg, 1987). Bassett, Snyder, Rogers and Collins (2013) applied the parenting styles model to teachers in 
higher education. They reported the results of two studies in which university students described an actual professor for the current semester using a modified version of the Parental Authority Questionnaire (Buri, 1991), which measures the extent to which a person displays the characteristics of the permissive, authoritarian and authoritative styles. In both studies, students expected to receive better grades in a class with the teacher described as being higher on the authoritative style and lower on the authoritarian style. Further, teachers described by students as higher on the authoritative style were perceived as setting higher achievement standards, fostering more interest in learning, being clearer, being more helpful, and being a better quality teacher overall.

Further studies of relationships between teaching styles and different areas of students' development point to the importance of consistent control, autonomy support and suitable responsiveness to students' needs (all characteristics of the authoritative teaching style). In one study, researchers (Patrick, Turner, Meyer, \& Midgley, 2005) identified three different types of classroom environment, all of which were established by the teachers' behaviour. The first type of classroom environment was named a "supportive environment". It was characterised by teachers' high expectations for student learning, teachers' use of humour and a high level of respect (authoritative teaching style). The second type of classroom environment was a "non-supportive environment". Teachers who created this type of environment emphasised extrinsic reasons for learning, used authoritarian control and expected children to misbehave or cheat in exams. The third type of classroom environment was named an "ambiguous environment" as some inconsistencies were perceived in the teaching style. On one hand, the teachers expressed a desire for student learning and high learning outcomes but, on the other, they had low expectations. Inconsistency was also perceived in teachers' assertion of control in the classroom. Researchers also examined students' views on learning and knowledge. Students whose classroom environment was supportive (with authoritative characteristics) expressed a less negative view on learning and knowledge than students who were in classes with a predominantly non-supportive or ambiguous classroom environment. In another study, Turner, Meyer, Midgley and Patrick (2003) researched relationships between teachers' responsiveness to children's needs and learning outcomes, and students experiencing unpleasant emotions with regard to school. The study results showed the authoritarian teaching style (especially a teacher's lack of warmth in their 
attitude to students and students' low autonomy regarding schoolwork) is related to students' negative emotions about learning and avoidance behaviour in their attitude to schoolwork.

To sum up, like parents, teachers also create contexts in which students develop social and academic competencies. As studies show that the authoritative parenting style gives the best support for a child's development in the home environment there is also evidence that characteristics of the authoritative teaching style help students in the teaching context.

Below we focus on students' engagement and students' self-determination. These two student outcomes are significantly correlated to teachers' teaching style (e.g. Roorda, Koomen, Spilt, \& Oort, 2011; Deci \& Ryan, 1987) and thus can presumably be impacted by teachers' carefully planned interventions in the classroom. Both outcomes have also been recognised as preventive factors for ESL (e.g. Doll \& Hess, 2001).

\section{Teaching style and students' engagement in school}

Students' engagement in school is probably one of the most important outcomes of an appropriate teaching style and positive student-teacher relationship (Roorda, Koomen, Spilt, \& Oort, 2011) especially regarding students at risk for ESL. Research shows that ESL is the outcome of a long process of disengagement with measurable indicators that are present already in the early grades of schooling (e.g. Barclay \& Doll, 2001; Barrington \& Hendricks, 1989). The concept of engagement has emerged as a critical theme in the process of understanding students' exit status from school (Doll \& Hess, 2001; Finn, 1993) and there is scientific evidence showing correlations between school disengagement and ESL (e.g. Finn \& Rock, 1997; Lamb, Dwyer, \& Wyn, 200o; McMillan \& Marks, 2003; Willms, 2003). Students' disengagement from school has been found to be a major cause of deviant behaviour at school, truanting, and low academic achievement (Lamb, Walstab, Tesse, Vickers, \& Rumberger, 2004).

Key ingredients of student engagement include student participation, identification with school or social bonding, academic performance, and personal investment in learning (Finn, 1993; Maehr \& Midgely, 1996). Researchers view engagement as a multidimensional construct, although many studies investigate only one dimension. Fredericks, Blumenfeld and Paris (2004) classified 44 engagement studies within behavioural, emotional and cognitive categories. Behavioural engagement is defined as student participation in academic, social and extracurricular activities. Students 
show emotional engagement when they have positive attitudes and reactions to school, teachers, learning and peers. Cognitive engagement is defined as students' personal investment in learning in a focused, strategic and self-regulating way. Fredricks et al. (2004) conclude that all three categories represent equally important dimensions of engagement and that more multidimensional research must be conducted. Research using this model has suggested that all three types of engagement cover different aspects of the student experience important for school success and personal development (Blumenfeld et al., 2005).

A student's school engagement includes both academic and social integration within the school (You \& Sharkey, 2009). When students are fully engaged in learning they achieve better academic outcomes (Finn \& Rock, 1997). Students who show a stable level of school engagement over the course of their schooling are less likely to leave the school before completing it (Janosz et al., 2008). The lack of attendance is a sign of a general disengagement from school, ultimately leading to ESL (Jimerson et al., 2000; Janosz et al., 2008). In one study (Archer \& Yamashita, 2003) former students were asked why they had dropped out of school. Their decision to leave school was mostly based on their self-concepts, explaining that they felt "not good enough" to continue and that they "knew their limits". Thus, it appears that through perceived failure in school students become so disengaged from the educational process that they believe that their 'place' lies elsewhere. However, it is important to note that ESLers are a heterogeneous group and there is a variety of reasons why they leave school.

Roorda, Koomen, Spilt and Oort, (2011) used a meta-analytic approach to investigate the associations between affective qualities of teacher-student relationships and students' school engagement and achievement. The analyses included 99 studies, referring to students from preschool to high school. Separate analyses were conducted for positive relationships and engagement, negative relationships and engagement, positive relationships and achievement, and negative relationships and achievement. The results of the meta-analysis show that associations of both positive and negative relationships with engagement were medium to large, whereas associations with achievement were small to medium.

The results of the research presented in this chapter show that the teacher-student relationship has an important impact on students' engagement in school. 


\section{Teaching style and students' self-determination}

Self-determination is another important outcome of a positive student-teacher relationship and teaching style. Different studies show the impact of teaching style on students' self-determination. Environments that support students' needs for competence and self-determination are autonomy-supportive environments (authoritative teaching style), whereas those that neglect and frustrate these needs are controlling environments (authoritarian teaching style) (Deci \& Ryan, 1987; Reeve et al., 1999). When students have autonomy-supportive teachers (Deci, Schwartz, Scheinman, \& Ryan, 1981; Deci, Spiegel, Ryan, Koestner, \& Kauffman, 1982) or when students perceive their teachers to be relatively autonomy-supportive (Grolnick \& Ryan, 1987; Rigby, Deci, Patrick, \& Ryan, 1992), they show relatively high levels of self-determination (Deci \& Ryan, 1985; Vallerand et al., 1997), competence (Deci, Nezlek, \& Sheinman, 1981; Ryan \& Grolnick, 1986), and valuing of school and school work (Ryan \& Connell, 1989). When supported and nurtured in the classroom, these motivational resources provide students with the motivational foundation they need to become highly engaged in school and committed to graduating and not at risk for ESL (Vallerand et al., 1997). According to self-determination theory, students become engaged in school-related activity when school activities are interesting, relevant to their everyday lives, and affirm and value their competencies. Perceptions of self-determination and competence build students' internal motivational resources that support their engagement and persistence in school. The important role teachers play in helping students develop these internal motivational resources occurs through the provision of autonomy-supportive classrooms, their supportive teaching style - authoritative teaching style and their responsiveness to students' individual needs, ideas etc.

\section{Teaching style impact on ESL}

Different characteristics of the authoritative teaching style (such as warmth, openness, support, supervision etc.) have been shown to help students at risk for ESL stay more engaged in school and thus be less prone to dropping out. For example, Fallu and Janosz (2003) showed that warm relationships with teachers decreased the ESL risk of at-risk students whereas conflictual relationships had negative consequences for all students in the classroom (also for students not at risk for ESL). Students who experience a warm relationship with their teacher are $16 \%$ less likely to leave school than 
students who report a negative relationship (Rumberger, 1995). Crosnoe, Kirkpatrick, Johnson and Elder (2004), Murray and Malgrem (2005) as well as Pianta and Stuhlman (2004) showed that a positive teacher-student relationship acts as a factor promoting school achievement which has also been proved to be a preventive factor for ESL (e.g. Garnier, Stein, \& Jacobs, 1997; Battin-Pearson et al., 2000; Fortin, Marcotte, Diallo, Potvin, \& Royer, 2013). Crosnoe et al. (2004) reported that a positive relationship with teachers helps boost achievement and lowers disciplinary problems among all students. In other words, the authoritative teaching style helps establish a positive student-teacher relationship which has been shown as a protective factor against ESL.

Further, a non-supportive classroom environment helps increase the risk for ESL (Lessard, Poirier, \& Fortin, 2010). According to results from different studies, non-supportive teacher behaviour characterised by conflicts may lead to behavioural problems and school failure (Hamre \& Pianta, 2001; Malecki \& Demaray, 2002), which are the two variables directly linked with ESL (Newcomb et al., 2002). For example, conflicts with teachers were reported by dropouts as one of the reasons motivating their decision to leave the school setting before obtaining their diploma (Lessard, Fortin, Marcotte, Potvin, \& Royer, 2009).

Within schools, teachers have a strong influence on the long-term academic trajectories of their students (Slaughter-Defoe \& Rubin, 2001). Different studies show (e.g. Vallerand \& Senecal, 1991; Poirier, Lessard, Fortin, \& Yergeau, 2013) that ESLers were more likely to perceive their teachers to be controlling, unsupportive and uninterested in them. However, the causal direction is not entirely clear as presumably ESLers are more likely to have on average lower motivation and less likely to elicit teachers' enthusiasm for their efforts (Poirier et al., 2013).

\section{Development of teaching style}

Studies show that teaching styles develop through teachers' work experience (Barnas, 2001). Results of some studies which mainly focused on fostering students' autonomy show teachers can learn how to foster students' autonomy and integrate it into their daily practice (Reeve, Bolt, \& Cai, 1999; Reeve, Jang, Carrell, Jeon, \& Barch, 2004).

The development of one's teaching style is an ongoing process based on teachers' professional growth and students' characteristics. Before teachers can attempt to develop more flexible teaching styles, they must 
be receptive to the idea of change, beginning with a change in their beliefs about the students' role in the learning environment (Heimlich \& Norland, 2002). It is the teacher's responsibility to recurrently analyse their teaching style, reflect on it and implement necessary changes. Constant reflection on one's own teaching practices, classroom activities and problem-solving approaches in the classroom are the basic teaching style monitoring approaches. Moreover, they also include a reflection on one's own beliefs about teaching and learning, the teacher-student relationship, expectations about one's own job etc.

Besides writing reflections on a specific classroom situation, teachers can also help themselves develop their teaching style by keeping a diary about their work and then analysing it to reflect on their professional development (Loughran, 2002). Videotaping own lessons from time to time also helps teachers become aware of some behaviours that may cause unwanted student reactions in the classroom. It also helps to ask a colleague teacher or the head teacher to observe a lesson and discuss their observations with you (Loughran, 2002).

\section{Conclusions}

In the article we addressed the relationship between teachers' teaching style and students' learning and social outcomes. Different studies show that teachers' behaviour in the classroom, their beliefs about teaching and learning - their teaching style - affects students' perceptions of their self-efficacy, competency, their attitude and the values of school and school work, their engagement in school, their self-determination etc. In most studies, teachers' warmth, openness, autonomy support and their responsiveness to students' needs and ideas have been shown to be the most important dimensions of the teaching style that influences students' self-efficacy, self-determination and helps students stay engaged in school and develop the internal motivation to finish it. These dimensions correspond with the authoritative parenting style, according to Baumrind (1967). On the contrary, the authoritarian teaching style which consists of excessive control and non-responsiveness to students' needs, interests and ideas creates an environment in which students develop low self-efficacy, they may perceive school as an environment not suitable for them and are more prone to leave it before they complete their education.

What is important for teachers to know is that they can help their students develop the right motivation to finish their educational programme. 
When teachers create a warm and autonomy-supportive classroom environment, they provide a climate that nurtures students' motivation directly, indirectly also affecting students' achievements and persistence (e.g. Moos, 1978; Ryan, Stiller, \& Lynch, 1994; Wentzel, 1997; Barnas, 2001; Walker, 2008; Wentzel, 2002). Moreover, focusing on teachers' teaching style can work as an effective ESL intervention and prevention strategy (Fallu \& Janosz, 2003) to be considered and presented to teachers and other school professionals.

\section{References}

Archer, L. \& Yamashita, H. (2003). 'Knowing their limits'? Identities, inequalities and inner city school leavers' post-16 aspirations, Journal of Education Policy, 18(1), 53-69.

Barclay, J. R., \& Doll, B. (2001). Early prospective studies of the high school dropout. School Psychology Quarterly, 16(4), 357.

Barrington, B. L., \& Hendricks, B. (1989). Differentiating characteristics of high school graduates, dropouts, and nongraduates. The Journal of Educational Research, 82(6), 309-319.

Barnas, M. (2001). 'Parenting' students: Applying developmental psychology to the classroom. Teaching Psychology, 27, 276-277.

Basow, S. A., Phelan, J. E., \& Capotosto, L. (2006). Gender patterns in college students' choices of their best and worst professors. Psychology of Women Quarterly, 30(1), 25-35.

Basow, S. A., \& Silberg, N. T. (1987). Student evaluations of college professors: Are female and male professors rated differently? Journal of Educational Psychology, 79(3), 308.

Bassett, J. F., Snyder, T. L., Rogers, D. T., \& Collins, C. L. (2013). Permissive, authoritarian, and authoritative instructors: Applying the concept of parenting styles to the college classroom. Individual Differences Research, 11(1), $1-11$.

Battin-Pearson, S., Newcomb, M., Abbott, R., Hill, K., Catalano, R., \& Hawkings, J. (2000). Predictors of early high school dropout: A test of five theories. Journal of Educational Psychology, 3, 568-582.

Baumrind, D. (1967). Child care practices anteceding three patterns of preschool behavior. Genetic Psychology Monographs, 75, 43-88.

Baumrind, D. (1971). Current patterns of parental authority. Developmental Psychology, 4 (1/2), 1-103. 
Behar-Horenstein, L. S., Mitchell, G. S., Notzer, N., Penfield, R., \& Eli, I. (2006). Teaching style beliefs among USA and Israeli faculty. Journal of Dental Education, $70(8), 851-856$.

Bennett, N. (1976). Teaching styles and pupil progress. American Educational Research Journal, 15, 158-169.

Blumenfeld, P., Modell, J., Bartko, W. T., Secada, W., Fredricks, J., Friedel, J., et al. (2005). School engagement of inner-city students during middle childhood. In C. Cooper, C. G. Coll, W. T. Bartko, H. Davis, \& C. Chatman (Eds.), Developmental pathway through middle childhood: Rethinking contexts and diversity as resources (pp. 145-170). London: Lawrence Erlbaum Associates.

Buri, J. R. (1991). Parental authority questionnaire. Journal of Personality Assessment, 57(1), 110-119.

Conti, G. J. (1985). Assessing teaching style in adult education: How and why. Lifelong Learning, 8(8), 7-11, 28.

Conti, G. J. (2004). Identifying your teaching style. Adult Learning Methods: A Guide for Effective Instruction, 3, 75-92.

Crosnoe, R., Kirkpatrick Johnson, M., \& Elder, G. H. (2004). Intergenerational bonding in school: The behavioral and contextual correlates of student-teacher relationships. Sociology of Education, $77(1), 60-81$.

Darling, N., \& Steinberg, L. (1993). Parenting style as context: An integrative model. Psychological Bulletin, 113(3), 487.

Deci, E. L., Nezlek, J., \& Sheinman, L. (1981). Characteristics of the rewarder and intrinsic motivation of the rewardee. Journal of Personality and Social Psychology, 40, 1-10.

Deci, E. L., \& Ryan, R. M. (1985). Intrinsic motivation and self-determination in human behavior. New York: Plenum Press.

Deci, E. L., \& Ryan, R. M. (1987). The support of autonomy and the control of behavior. Journal of Personality and Social Psychology, 53, 1024-1037.

Deci, E. L., Schwartz, A., Scheinman, L., \& Ryan, R. M. (1981). An instrument to assess adult's orientations toward control versus autonomy in children: Reflections on intrinsic motivation and perceived competence. Journal of Educational Psychology, 73, 642-650.

Deci, E. L., Spiegel, N. H., Ryan, R. M., Koestner, R., \& Kauffman, M. (1982). Effects of performance standards on teaching styles: Behavior of controlling teachers. Journal of Educational Psychology, 74, 852-859. 
Doll, B., \& Hess, R. S. (2001). Through a new lens: Contemporary psychological perspectives on school completion and dropping out of high school. School Psychology Quarterly, 16(4), 351.

Dupin-Bryant, P. A. (2004). Variables related to interactive television teaching style: In search of learner-centered teaching styles. International Journal of Instructional Technology and Distance Learning, 1(4), 3-14.

Fallu, J. S., \& Janosz, M. (2003). La qualité des relations élève-enseignants à l'adolescence: Un facteur de protection de l'échec scolaire. Revue de psychoéducation et d'orientation, 32(1), 7-29.

Finn, J. D. (1993). School engagement \& students at risk. Washington, DC: National centre for educational statistics.

Finn, J., \& Rock, D. (1997). Academic success among students at risk for school failure. Journal of Applied Psychology, 82(2), 221-234.

Fisher, B., \& Fisher, L. (1979). Styles in Teaching and Learning. Educational Leadership, 36, 245-251.

Flanders, N. A. (1970). Analyzing teaching behavior. Reading, MA: Addison-Wesley.

Fortin, L., Marcotte, D., Diallo, T., Potvin, P., \& Royer, É. (2013). A multidimensional model of school dropout from an 8-year longitudinal study in a general high school population. European Journal of Psychology of Education, 28(2), 563-583.

Fredricks, J. A., Blumenfeld, P. C., \& Paris, A. H. (2004). School engagement: Potential of the concept, state of the evidence. Review of Educational Research, 74(1), 59-109.

Garnier, H. E., Stein, J. A., \& Jacobs, J. K. (1997). The process of dropping out of high school: A 19-year perspective. American Educational Research Journal, 34(2), 395-419.

Grasha, A. F. (1996). Teaching with style. Pittsburgh, PA: Alliance.

Good, T. L., \& Grouws, D. A. (1979). Teaching and mathematics learning. Educational Leadership, 37(1).

Gregory, A., \& Weinstein, R. S. (2004). Connection and regulation at home and in school predicting growth in achievement for adolescents. Journal of Adolescent Research, 19(4), 405-427.

Grolnick, W. S., \& Ryan, R. M. (1987). Autonomy in children's learning: An experimental and individual differences investigation. Journal of Personality and Social Psychology, 52, 890-898. 
Heimlich, J. E., \& Norland, E. (1994). Developing teaching style in adult education. The Jossey-Bass higher and adult education series. San Francisco: Jossey-Bass, Publishers.

Heimlich, J. E., \& Norland, E. (2002). Teaching style: where are we now? New Directions for Adult and Continuing Education, 2002(93), 17-26.

Hamre, B. K., \& Pianta, R. C. (2001). Early teacher-child relationships and the trajectory of children's school outcomes through eighth grade. Child Development, 72(2), 625-638.

Janosz, M., Archambault, I., Morizot, J., \& Pagani, L. S. (20o8). School engagement trajectories and their differential predictive relations to dropout. Journal of Social Issues, 64(1), 21-40.

Jimerson, S. R., Egeland, B., Sroufe, L. A., \& Carlson, B. (2000). A prospective longitudinal study of high school dropouts: Examining multiple predictors across development, Journal of School Psychology, 38(6), 525-549.

Lamb, S., Dwyer, P., \& Wyn, J. (200o). Non-completion of school in Australia: The changing patterns of participation and outcomes. Camberwell, Vic: The Australian Council for Educational Research.

Lamb, S., Walstab, A., Tesse, R., Vickers, M., \& Rumberger, R. (2004). Staying on at school: Improving student retention in Australia (Report for the Queensland Department of Education and the Arts). Melbourne: Centre for Post-compulsory Education and Lifelong Learning.

Lan, W., \& Lanthier, R. (2003). Changes in students' academic performance and perceptions of school and self before dropping out of schools. Journal of Education for Students Placed at Risk, 8(3), 309-332.

Lee, T., \& Breen, L. (2007). Young people's perceptions and experiences of leaving high school early: An exploration. Journal of Community \& Applied Social Psychology, 17(5), 329-346.

Lessard, A., Fortin, L., Marcotte, D., Potvin, P., \& Royer, É. (2009). Why did they not drop out? Narratives from resilient students. The Prevention Researcher, 16(3), 21-25.

Lessard, A., Poirier, M., \& Fortin, L. (2010). Student-teacher relationship: A protective factor against school dropout? Procedia-Social and Behavioral Sciences, 2(2), 1636-1643.

Loughran, J. J. (2002). Developing reflective practice: Learning about teaching and learning through modelling. London: Falmer Press.

Maehr, M. L., \& Midgley, C. (1996). Transforming school cultures. Boulder, CO: Westview Press. 
Malecki, C. K., \& Demaray, M. K. (2002). Measuring perceived social support: Development of the child and adolescent social support scale (CASSS). Psychology in the Schools, 39(1), 1-18.

McMillan, J., \& Marks, G. N. (2003). School leavers in Australia: Profiles and pathways (No. 31). Camberwell: The Australian Council for Educational Research.

Mccombs, B. L. \& Whisler, J. S. (1997). The Learner-centered Classroom and School. San Francisco: Jossey-Bass Publishers.

Moos, R. (1978). A typology of junior high and high school classrooms. American Educational Research Journal, 15, 53-66.

Murray, C., \& Malmgren, K. (2005). Implementing a teacher-student relationship program in a high-poverty urban school: Effects on social, emotional, and academic adjustment and lessons learned. Journal of School Psychology, 43(2), 137-152.

Newcomb, M. D., Abbott, R. D., Catalano, R. F., Hawkins, J. D., BattinPearson, S., \& Hill, K. (2002). Mediational and deviance theories of late high school failure: Process roles of structural strains, academic competence, and general versus specific problem behavior. Journal of Counseling Psychology, 49(2), 172.

Patrick, H., Turner, J. C., Meyer, D. K., \& Midgley, C. (2005). How teachers establish psychological environments during the first days of schools: Associations with avoidance in mathematics. Teachers College Record, 105, 1521-1558.

Pianta, R. C., \& Stuhlman, M. W. (2004). Teacher-child relationships and children's success in the first years of school. School Psychology Review, 33(3), 444 .

Pillay, H. (2002). Teacher development for quality learning: The Thailand education reform project. Brisbane: Queensland University of Technology.

Poirier, M., Lessard, A., Fortin, L., \& Yergeau, É. (2013). La perception différenciée de la relation élève-enseignant par les élèves à risque et non à risque de décrochage scolaire. Nouveaux c@ hiers de la recherche en éducation, 16(1), 1-23.

Ryan, R. M., \& Grolnick, W. S. (1986). Origins and pawns in the classroom: Selfreport and projective assessments of individual differences in children's perceptions. Journal of Personality and Social Psychology, 50, 550-558.

Ryan, R. M., \& Connell, J. P. (1989). Perceived locus of causality and internalization: Examining reasons for acting in two domains. Journal of Personality and Social Psychology, 57, 749-761. 
Ryan, R. M., Stiller, J.D., \& Lynch, J. H. (1994). Representations of relationships to teachers, parents, and friends as predictors of academic motivation and self-esteem. Journal of Early Adolescence, 14, 226-249.

Reeve, J., Bolt, E., \& Cai, Y. (1999). Autonomy-supportive teachers: How they teach and motivate students, Journal of Education Psychology, 91, 537-548.

Reeve, J., Jang, H., Carrell, D., Jeon, S., \& Barch, J. (2004). Enhancing students' engagement by increasing teachers' autonomy support, Motivation and Emotion, 28, 147-169.

Rigby, C. S., Deci, E. L., Patrick, B. P., \& Ryan, R. M. (1992). Beyond the intrinsic-extrinsic dichotomy: Self-determination in motivation and learning. Motivation and Emotion, 16, 165-185.

Roorda, D. L., Koomen, H. M., Spilt, J. L., \& Oort, F. J. (2011). The influence of affective teacher-student relationships on students' school engagement and achievement a meta-analytic approach. Review of Educational Research, 81(4), 493-529.

Rumberger, R. W. (1995). Dropping out of middle school: A multilevel analysis of students and schools. American Educational Research Journal, 32(3), $583-625$.

Schultz, R. A. (1982). Teaching style and sociopsychological climates. Alberta Journal of Educational Research, 28, 9-18.

Slaughter-Defoe, D. T., \& Rubin, H. (2001). A longitudinal case study of head start eligible children: Implications for urban education. Educational Psychologist, 36, 31-44.

Tyler, J. H., \& Lofstrom, M. (2009). Finishing high school: Alternative pathways and dropout recovery. The Future of Children, 19(1), 77-103.

Turner, J. C., Meyer, D. K., Midgley, C., \& Patrick, H. (2003). Teacher discourse and sixth graders' reported affect and achievement in two high-mastery/ high-performance mathematics classrooms, Elementary School Journal, $103,357-430$.

Vallerand, R. J., \& Senecal, S. (1991). Une analyse motivationnelle de l'abandon des etudes [The role of motivation in school dropout]. Apprentissage et socialisation, 15(1), 49-62.

Vallerand, R. J., Fortier, M. S., \& Guay, F. (1997). Self-determination and persistence in a real-life setting: Toward a motivational model of high school dropout. Journal of Personality and Social Psychology, 72, 1161-1176.

Weimer, M. (2002). Learner-centered teaching: Five key changes to practice. San Francisco: John Wiley \& Sons. 
Walker, J. M. T. (2008). Looking at teacher practices through the lens of parenting style. The Journal of Experimental Education, 76(2), 218-240.

Walker, J. M. (2009). Authoritative classroom management: How control and nurturance work together. Theory into Practice, 48(2), 122-129.

Wentzel, K. R. (1997). Student motivation in middle school: The role of perceived pedagogical caring. Journal of Educational Psychology, 86, 173-182.

Wentzel, K. R. (2002). Are effective teachers like good parents? Teaching styles and student adjustment in early adolescence. Child Development, 73(1), 287-301.

Willms, J. D. (2003). Student engagement at school: A sense of belonging and participation (Results from PISA 2000). Paris: OECD.

You, S. \& Sharkey, J. (2009). Testing a developmental-ecological model of student engagement: A multilevel latent growth curve analysis, Educational Psychology, 29(6), 659-684.

Zophy, J. W. (1982). On learner-centered teaching. The History Teacher, 15(2), 185-196. 


\section{3 .2}

\section{How Teacher-teacher and Teacher-student Cooperation Link with Achievement - Evidence from International Studies}

Mojca Štraus

\section{Synopsis}

Evidence from international large-scale assessment studies shows that more complex professional collaboration between teachers and teacher-student relations is associated with an improvement in student achievement, even when considering differences in students' backgrounds. It may also be important that teachers who collaborate more with their colleagues generally report more positive teacher-student relations.

\section{Summary}

Studies on early school leaving (ESL) have shown that (low) student achievement is an important predictor of ESL. This paper presents a literature review of evidence from international large-scale assessments (ILSA studies) on associations between teacher-teacher and teacher-student cooperation and student achievement. Due to their cross-sectional nature, the ILSA studies cannot provide direct evidence of a link between cooperation practices in schools and ESL. However, ILSA studies do offer evidence, first, on the kinds of cooperation practices found in schools internationally and, second, that students in schools where there is more (of specific types of) collaboration have, on average, higher achievement. While a beneficial effect of cooperation practices on student learning exists, it is embedded in the context of the ILSA data that also reveal that 
basic coordination and exchange of information and material is a much more common form of teacher-teacher cooperation than more complex forms of professional collaboration. Further, teachers differ among each other in their cooperation practices to a greater extent within the school than between the schools.

Teacher-student cooperation was investigated by relying on ILSA indicators of teacher-student relations, disciplinary and school climate. For these, ILSA studies show that students as well as teachers and principals generally reported good relations and a good climate. Associations between the indicators and student achievement were also found in ILSA, revealing that students who learn in an orderly and peaceful classroom climate and enjoy good teacher-student relations tend to perform better. However, these associations may differ if reports on the climate are given by principals, teachers or students. Indirect ILSA evidence further indicates that students in schools where teacher-student relations and the disciplinary climate are poor are more likely to have low levels of engagement with and at school. This is important because the research identified low engagement as one of the warning signs for students at risk of ESL.

Key words: teacher-student relationship, international comparative assessments, engagement

\section{Introduction}

Student achievement has been shown to be a very important factor in predicting ESL (e.g. Bushnik, Barr-Telford, \& Bussière, 2004; Knighton \& Bussière, 2006; Lessard, 2010; Marks, 2007). Therefore, if cooperation practices in schools influence student achievement they are (indirectly) important for the context of ESL. However, due to their cross-sectional design international large-scale assessments (hereafter ILSA studies) cannot investigate the causal effects of factors on student achievement or even ESL. With cross-national comparisons of student achievement in relation to the education system, school and student background, they offer a way to gain insight into educational processes and practices occurring in successful systems and schools.

In ILSA studies the investigation of cooperation practices in schools is carried out using background questionnaires. Several ILSA studies used teacher questionnaires to collect data on teacher characteristics and their teaching and cooperation practices in an effort to find those that are linked 
to (higher) student achievement. However, investigations of ILSA data were unable to clearly identify teacher characteristics and classroom practices that could be directly linked to an improvement in student learning. For example, using TIMSS 2003 data Akiba (2007) found that teacher variables like education and experience are positively related to student outcomes across 46 countries. Similarly, Liang, Zhang, Huang, Shi and Qiao (2015) used TIMSS 2003, 2007 and 2011 data to show a positive association between the national maths achievement and the percentages of students whose teachers had participated in professional development. In contrast, Luschei and Chudgar (2011) reported they found only limited evidence that teacher characteristics are related to student achievement.

As discussed by Schleicher (2016), teaching is a complex task that involves interactions with a great variety of learners in a wide range of different circumstances and so there is not one single set of teacher attributes and behaviours that is universally effective for all types of students and learning environments. The lack of a strong relationship between teacher characteristics and student achievement in the ILSA studies may be due to the complexity and diversity of teacher professionalism and not all the facets of teacher professionalism being equally efficient (ibid.).

This paper presents a literature review of studies using ILSA data to address the associations between teacher-teacher or teacher-student cooperation and student achievement. In the next section, we present the methods used in the search. The results of our search first present a review of conceptual understanding of the teacher-teacher and teacher-student cooperation that are then followed by research findings on the associations of each type of cooperation with student achievement. Finally, some conclusions are given.

\section{Methods of research}

The initial challenge in performing a literature search in this paper is a conceptual one. Due to their design, ILSA studies provide a broad overview of the state of affairs in education systems, making it is impossible to derive thorough definitions or measurements of individual background concepts. This is also the case for the concepts of teacher-teacher and teacher-student cooperation and therefore our search for literature was somewhat constrained. More specifically, for the literature search to produce results, the terms entered in the search related to teacher-teacher and teacher-student cooperation in the broadest sense, most notably including collaboration 
and teacher-student relations or otherwise accommodating the definitions from the particular ILSA study in question.

Literature searches for the review in this paper were performed on diverse search engines and bibliographical databases, library catalogues and websites, starting with international reports of the results of the above studies. Key words used in the search were different combinations of the names and acronyms of the studies or terms "international assessments", "international studies" etc. and "collaboration", "cooperation", "teacher-student relationship" etc. As mentioned, the search with the terms "early school leaving" or "dropout" proved to be too narrow and did not produce any results. The results described below therefore do not address ESL directly but provide a wider international context of associations between teacher-teacher or teacher-student cooperation and student achievement.

Among ILSA studies that have collected data about cooperation practices in schools, the largest sets of constructs can be found in the Teaching and Learning International Survey (TALIS) conducted in 2008 and 2013 in connection with the PISA with the latest cycle of 2012. Some data can also be found in the International Study of Computer and Information Literacy Study (ICILS) carried out in 2013, the Trends International Mathematics and Science Study (TIMSS) and the Progress in International Reading Literacy Study (PIRLS), both with the latest data collection in 2011.

\section{Conceptual background of teacher-teacher and teacher- student cooperation}

In our literature review it became evident that research on teacher cooperation practices occurring in schools is embedded in the research of the concepts of teacher professionalism and professional learning communities. Based on the view that teacher quality is the key to student achievement, these concepts have gained research prominence in the past decades (Darling-Hammond \& Lieberman, 2013). In their meta-analysis, Lomos, Hofman and Bosker (2011a) discuss how the professional community concept has had a long development process, starting around 1982 with the introduction of collegiality and collaboration and developed around 2000 into professional learning community. From their meta-analysis and drawing from a number of previous studies they derive the concept with five dimensions; namely, reflective dialogue, de-privatisation of practice or feedback on instruction, collaborative activity, shared sense of purpose, and a 
collective focus on student learning. ${ }^{\mathrm{I}}$ Using the TALIS data, the concept of professional learning communities was studied by Vieluf, Kaplan, Klieme and Bayer (2012).

A report by the OECD (2016) addressed teacher cooperation practices by conceptualising teacher professionalism as consisting of three major domains: 1) professional knowledge (formal teacher education, professional development opportunities, practitioner research); 2) teachers' autonomy in decision-making (autonomy, school-based decision-making); and 3) high peer networks (mentoring, induction, professional development plans, peer feedback, professional learning communities). Within this concept, the authors emphasised that maintaining high professional practices takes various forms, most of which stress peer collaboration and networks of information exchange, knowledge sharing and collective standard setting (ibid.).

In TALIS it was recognised that the cooperation of teachers can take various forms; teachers may, for example, exchange instructional materials and meet regularly for discussions about individual students while more complex forms of cooperation, named in TALIS professional collaboration, include collective learning activities such as observing others and providing feedback as well as engaging in professional learning activities and joint activities across classes and age groups (e.g. OECD, 2009). Notably, the TALIS data consistently show professional collaboration practices are still relatively rare compared with practices that focus on coordination and the exchange of information and material (ibid.). Similarly, in reporting on teacher-teacher cooperation in the context of using ICT for teaching and learning the ICILS study (Fraillon et al., 2014) showed that collaboration with colleagues ${ }^{2}$ was on average across countries reported by schools to represent less than half the student population. This confirms the TALIS findings that more demanding collaborating practices are not very common.

1 In their explanation reflective dialogue refers to the extent to which teachers engage in professional dialogues about specific educational issues. De-privatisation of practice means that teachers observe another's classes with the aim of giving and receiving feedback. Collaborative activity represents a temporal measure of the extent to which teachers engage in cooperative practices. Shared sense of purpose refers to the degree to which the teachers agree with the school's mission and its operational principles. Finally, the collective focus on student learning indicates the mutual commitment of teachers to student success.

2 In ICILS teachers were asked about collaboration practices that had the intention of teacher learning, such as "working with another teacher who has attended a course" or "observing colleagues using ICT in their teaching". 
In contrast, according to teacher self-reports from TIMSS 2011 (Martin et al., 2012; Mullis et al., 2012a) and PIRLS 2011 (Mullis et al., 2012b) it seems that almost all students have the benefit of teachers who collaborate with other teachers to improve instruction. Compared to the TALIS and ICILS data, these reports seem to be somewhat overstated. Finally, TALIS showed that the majority of the variance in constructs about cooperation between teachers remains at the individual level with the teacher. In other words, teachers differ from each other in their cooperation practices even within the same school (OECD, 2009; OECD, 2014).

An example of conceptual development of teacher-student cooperation can be found in Jennings and Greenberg (2009). Their model highlights the importance of teachers' social and emotional competence for the development of a classroom climate that is more conductive to learning and promotes positive developmental outcomes among students (ibid.). In the ILSA studies, teacher-student cooperation is represented with indicators of teacher-student relations, school and disciplinary climate (e.g. Mullis et al., 2012a; OECD, 2013a). For example, in PISA students were asked about the student-teacher relationship in terms of whether students get along with their teachers, are teachers interested in their personal well-being, whether teachers take the students seriously, whether teachers are a source of support if a student needs extra help, whether teachers treat students fairly. In PISA, students generally reported good relations and differences between students in their views of teacher-student relations are mostly found within schools and much less between schools (OECD, 2013b). In TALIS 2013, principals and teachers also reported good relations between teachers and students and it is only in the area of providing students with extra support that any variation is observed (OECD, 2014). In relation to the concept of teacher-teacher cooperation, TALIS 2008 showed that teachers who exchange ideas and information and coordinate their practices with other teachers generally report more positive teacher-student relations at their school (OECD, 2009).

The above concepts provide a theoretical background for the results of our literature review regarding evidence on the link between cooperation practices in schools and student achievement that can be found among the ILSA studies. 


\section{Link between teacher-teacher cooperation and student achievement}

In this section, we start by shortly discussing general evidence on the link between teacher-teacher cooperation and student achievement. After that, we present the results found specifically from the ILSA studies.

Lomos et al. (2011a) explain that empirical evidence on the relationship between teacher-teacher cooperation (more specifically, conceptualised in their study as professional community) and student achievement is diverse and has produced mixed results, ranging from small to medium impacts. Although relatively small, their meta-analysis shows that the relationship between professional community and student achievement is positive and significant. That well-developed professional learning communities have a positive impact on both teaching practice and student achievement was also confirmed in a review by Vescio, Ross and Adams (2008). A thorough analysis is reported by Akiba and Liang (2016) in which they used a longitudinal study design to show that teacher-centred collaborative activities to learn about mathematics teaching and learning, namely teacher collaboration and informal communication, are more effective in improving student mathematics achievement compared to learning activities that do not necessarily involve such teacher-centred collaborative opportunities. Examples include professional development programmes, university courses and individual learning activities.

Our literature search on the studies using ILSA data also provided evidence that student achievement is positively associated with teachers and schools working as professional learning communities. Lomos, Hofman and Bosker (2011b) applied cluster analysis and hierarchical linear modelling to the TIMSS 2003 data to investigate the relationship between the aspects of mathematics department units as professional learning communities (as described in the conceptual background) and student achievement in Dutch secondary schools. The study showed that those departments which worked as professional learning communities are associated with successful schools and higher student achievement. After controlling for background variables at the student and teacher/school levels, an additional $7 \%$ of the variance among schools was explained by the presence of the above-mentioned dimensions of mathematics departments as professional communities. However, only the focus on student learning showed a direct positive effect on achievement in the model which, according to the authors, indicated that higher expectations of teachers with respect to 
the success of their students are associated with higher levels of student achievement. While the effects of reflective dialogue or collaboration were non-significant in the model, the authors state that this may be because there are indirect effects of teacher interaction on student achievement.

Associations between teacher collaboration and student achievement were also investigated in the reports of TIMSS 2011 (Martin et al., 2012; Mullis et al., 2012a) and PIRLS 2011 (Mullis et al., 2012b). Generally, both assessments in the domains and populations studied show that students had essentially the same average reading, mathematics or science achievement irrespective of whether their teachers were categorised as "very collaborative" or "collaborative". Arguably, this non-differential effect of higher collaboration on student achievement may be due to the small variation in teacher self-reports about their collaboration practices, as mentioned in the previous section.

There is also evidence from ILSA studies that indirectly suggests a link between cooperation practices among teachers and student achievement. Schleicher (2016) states that evidence from TALIS that also draws on other studies (Cordingley et al., 2015; Liaw, 2009; Puchner \& Taylor, 2006) shows that collaboration among teachers may enhance teacher efficacy which, in turn, may improve student achievement and sustain positive teacher behaviours. As revealed by TALIS, the practice most strongly related to teachers' self-efficacy is taking part in collaborative professional learning and, further, there is evidence of collaborative professional development being linked to a positive influence on student learning processes, motivation and outcomes (Schleicher, 2016).

That building a collaborative school culture is key to successful schooling can also be observed from PISA. The OECD (2013b) report discusses that the nature of the relationship between school autonomy in allocating resources and student performance depends on whether there is a culture of collaboration between teachers and principals in managing the school. In systems where teacher participation in managing the school was higher than the OECD average, students in schools with greater autonomy achieved higher than students in schools with less autonomy. Contrastingly, in systems where teacher participation in managing the school was lower than the OECD average, students in schools with greater autonomy achieved lower than students in schools with less autonomy (ibid.). School autonomy combined with a culture of participatory leadership tends to be associated with better learning outcomes (Schleicher, 2016). 
The ICILS report indirectly addressed the link between teacher collaboration and student achievement by indicating that teachers were most likely to use ICT for teaching when they worked in school environments where there was collaboration and planning concerning ICT use, and where there were fewer resource-based obstacles to using ICT (Fraillon et al., 2014). ${ }^{3}$ The report emphasises that these showed to be the conditions which supported teaching about computer and information literacy. In other words, this suggests that if students' computer and information literacy is to be developed to the greatest extent possible, then teacher expertise in ICT use needs to be developed and supported by collaborative environments that incorporate institutional planning (ibid.).

Overall, it can be concluded that the ILSA studies provide evidence on teacher-teacher professional collaboration, such as observing others and providing feedback or joint activities across classes and age groups, positively influencing student achievement.

\section{Link between teacher-student cooperation} and student achievement

In the conceptual background section, we explained that for the purposes of our review the concept of teacher-student cooperation is characterised by indicators of teacher-student relations, classroom disciplinary climate and school climate. Although there are mixed results concerning whether good teacher-student relationships serve as a directly protective factor against ESL (e.g. Lessard, Pirier, \& Fortina, 2010; Murray \& Malmgrenb, 2005), there are findings showing that students, particularly disadvantaged students, learn more and have fewer disciplinary problems when they feel their teachers take them seriously (Gamoran, 1993) and when they have strong and affective bonds with their teachers (Crosnoe, Johnson, \& Elder, 2004).

In our search, it was possible to find ILSA evidence that teacher-student relations and school climate are important for student achievement. For example, several studies used national or international PISA data to show that school (Azigwe, 2016) and classroom climate (Bove, Marella, \& Vitale, 2016) as well as teacher-student relations more specifically (Kalender, 2015; Konishi, Hymel, Zumbo, \& Li, 2010; Mikk, Krips, Saalik, \& Kalk, 2015) are significantly associated with student achievement, even after accounting

3 Another factor mentioned was that teachers were confident in their expertise in this regard. 
for other student, teacher and school characteristics. Mikk et al. (2015) revealed that the strongest (and a positive) correlation between teacher-student relations and student achievement exists at the school level, followed by correlation at the student level. At the country level, a negative correlation was found, a phenomenon also called ecological fallacy due to the different contexts in which students' perceptions of teacher-student relations are developed. For Canada, Konishi et al. (2010) additionally discovered that, for boys, teacher-student connectedness acts as a buffer against the effects of bullying on their mathematics and reading achievement.

Disciplinary climate was found in PISA to be related to higher average performance at the school level. Although it can be recognised that schools with a more negative disciplinary climate tend to have a largely disadvantaged student population, have greater socio-economic diversity among students, and suffer from more teacher shortages, the data also show that even when comparing schools of similar SES students in schools with more disciplinary problems tend to perform worse than their peers in schools with a better disciplinary climate (OECD, 2013b).

In their analysis of the TIMSS 2007 and TIMSS Advanced 2008 data for Slovenia, Kozina, Rožman, Vršnik Perše and Rutar Leban (2012) showed that in secondary school all types of evaluations of the school climate (performed by principals, teachers and students) are significant predictors of mathematics and science achievement. The evaluation performed by the principals showed to be the strongest predictor, followed by the evaluation by the teachers and last that by the students. They found that the predictive power of school climate seems to increase from the elementary to secondary school level. The results also showed that a positive school climate correlates with higher student achievement in both elementary and secondary schools when evaluated by teachers and principals, and with low student achievement when evaluated by the students of secondary and elementary schools (possibly because teachers high expectations regarding students' achievement were one of the characteristics of a positive school climate in the study). The finding that school climate as perceived by the school principals is the most influential factor on the achievement of students was also made by Ghagar, Othman and Mohammadpour (2011) for Singapore and Malaysia. The authors performed school-level analyses on TIMSS 2003 data.

Mistele and Louis (2011) built a path model on TIMSS 2007 data to understand the impact the teacher-student relationship may have on student 
mathematics achievement by exploring the associations between teacher attitudes as perceived by their students, student attitudes and student achievement. The authors conjectured that a crucial component for middle school students experiencing success and confidence, while engaged in rigorous mathematics classes, begins with the relationship between the teacher and the student. The results of path analyses suggested that teacher attitude is indeed a mediating factor between student attitude and student mathematics scores (ibid.).

ILSA studies provide additional evidence of associations between teacher-student relations and so-called non-cognitive educational results that have been shown important for student achievement. For example, PISA showed (OECD, 2013a) that teacher-student relations are strongly associated with students' engagement with and at school and with students' mathematics self-efficacy. Among students with equal performance and similar SES, those who attend schools with better teacher-student relations reported a stronger sense of belonging and greater intrinsic motivation to learn mathematics (ibid.). From the opposite point of view, PISA showed that students who are in schools where teacher-student relations and disciplinary climate are poor are more likely to have low levels of engagement with and at school. They are more likely to arrive late for school, skip classes or days of school, report a weak sense of belonging, and hold negative attitudes to school. A lack of engagement - on the part of either teachers or students - can have adverse effects on the entire school community (Schleicher, 2016) and research has established that lack of engagement is one of the warning signs for students that later become ESLers (e.g. Lamb, Markussen, Teese, Sandberg, \& Polesel, 2011).

In summary, students who learn in a school climate characterised by high expectations, classrooms conducive to learning, and good teacher-student relations tend to perform better than those who do not (OECD, 2013b). According to Bove et al. (2016), an orderly and peaceful atmosphere in schools and classrooms together with cognitively activating instruction help to transform existing interests into mathematics achievement.

\section{Conclusion}

The more interdependent the world becomes, the more society relies on collaboration and schools need to prepare students to successfully mobilise, share and link knowledge (Schleicher, 2016). In this article, we presented a literature review of ILSA evidence on the link between teacher-teacher 
and teacher-student cooperation with student achievement. Our review shows that when appropriately organised and targeted cooperation practices in schools of both types between teachers and between teachers and students may positively influence student outcomes. The main ILSA findings from our search may be summarised in more complex professional collaboration between teachers, teacher-student relations and overall school climate being associated with an improvement in student achievement, even when considering students' different backgrounds. It may also be important that teachers who collaborate more with their colleagues generally report more positive teacher-student relations.

In conclusion, building a collaborative school culture is key to many dimensions of school life including student outcomes. However, in his analysis of the difficulties in building collaborative cultures in schools Hargreaves (2004) warns that when collegiality is directed from above it inhibits bottom-up professional initiative and results in teachers actually collaborating less or abandoning collaborative ways of working as soon as the urgency of creating or implementing a school improvement plan is over. Building a collaborative culture therefore needs to be a collaborative process.

\section{References}

Akiba, M., LeTendre, G. K., \& Scribner, J. P. (2007). Teacher quality, opportunity gap, and national achievement in 46 countries. Educational Researcher, 36(7), 369-387.

Akiba, M., \& Liang, G. (2016). Effects of teacher professional learning activities on student achievement growth. The Journal of Educational Research, 109(1), 99-110

Azigwe, J. B. (2016). Using comparative international studies for modeling educational effectiveness: A secondary analysis of PISA-20o9 study. Journal of Education and Practice, 7(18), 199-209.

Bolam, R., McMahon, A., Stoll, L., Thomas, S., Wallace, M., Greenwood, A. et al. (2005). Creating and sustaining effective professional learning communities. London, UK: DfES and University of Bristol.

Bove, G., Marella, D., \& Vitale, V. (2016). Influences of school climate and teacher's behavior on student's competencies in mathematics and the territorial gap between Italian macro-areas in PISA 2012. Journal of Educational, Cultural and Psychological Studies, 13, 63-96. 
Bushnik, T., Barr-Telford, L., \& Bussière, P. (2004). In and out of high school: First results from the second cycle of the Youth in Transition Survey. Statistics Canada Research papers - Education, skills and learning, Catalogue no. 81-595-MIE - No. 014. Ottawa, Canada: Statistics Canada and Human Resources and Skills Development Canada.

Cordingley, P., Higgins, S., Greany, T., Buckler, N., Coles-Jordan, D., Crisp, B., Saunders,

L., \& Coe, R. (2015). Developing great teaching: Lessons from the international reviews into effective professional development. London, UK: Teacher Development Trust. Retrived from www.tdtrust.org/wp-content/uploads/ 2015/10/DGT-Full-report.pdf

Crosnoe, R., Johnson, M., \& Elder, G. (2004). Intergenerational bonding in school: The behavioral and contextual correlates of student-teacher relationships. Sociology of Education, 77(1), 60-81.

Darling-Hammond, L., \& Lieberman, A. (Eds.) (2013). High quality teaching and learning: Changing policies and practices. London, UK: Routledge.

DuFour, R. (2004). What is a 'professional learning community'? Educational Leadership, 61, 6-11.

Fraillon, J., Ainley, J., Schulz, W., Friedman, T., \& Gebhardt, E. (2014). Preparing for life in a digital age: The IEA International Computer and Information Literacy Study international report. Amsterdam, the Netherlands: International Association for the Evaluation of Educational Achievement (IEA).

Gamoran, A. (1993). Alternative uses of ability grouping in secondary schools: Can we bring high-quality instruction to low-ability classes? American Journal of Education, 102(1), 1-12.

Ghagar, M. N. A., Othman, R., \& Mohammadpour, E. (2011). Multilevel analysis of achievement in mathematics of Malaysian and Singaporean students. Journal of Educational Psychology and Counseling, 2, 285-304.

Hargreaves, D. (2004). Policy for educational innovation in the knowledge-driven economy. In OECD, Innovation in the knowledge-based economy: Implications for education and learning systems, knowledge management. Paris, France: OECD Publishing.

Jennings, P. A., \& Greenberg, M. T. (2009). The prosocial classroom: Teacher social and emotional competence in relation to student and classroom outcomes. Review of Educational Research, 79(1), 491-525. 
Kalender, I. (2015). An analysis of the resilient students' profile based on PISA 2012. Journal of Measurement and Evaluation in Education and Psychology, 6(1), 158-172.

Konishi, C., Hymel, S., Zumbo, B. D., \& Li, Z. (2010). Do school bullying and student-teacher relationships matter for academic achievement? A multi-level analysis. Canadian Journal of School Psychology, 25(1), 19-39.

Kozina, A., Rožman, M., Vršnik Perše, T., \& Rutar Leban, T. (2012). Napovedna vrednost različnih ocen šolske klime na dosežke $\mathrm{v}$ raziskavah TIMSS [Predictive value of different school climate evaluations for TIMSS research findings]. Didactica Sovenica - Pedagoška obzorja, 1-2, 127-144.

Knighton, T., \& Bussière, P. (2006). Educational outcomes at age 19 associated with reading ability at age 15 . Research paper - Catalogue no. 81-595-MIE - No. 043. Ottawa, Canada: Statistics Canada and Human Resources and Skills Development Canada.

Lamb, S., Markussen, E., Teese, R., Sandberg, N., \& Polesel, J. (Eds.) (2011). School dropout and completion. International comparative studies in theory and policy. Dordrecht, The Netherlands: Springer.

Lee, V. S. E., \& Smith, J. (1996). Collective responsibility for learning and its effects on gains in achievement and engagement for early secondary students. American Journal of Education, 104, 103-147.

Lessard, A., Poirier, M., \& Fortina, L. (2010). Student-teacher relationship: A protective factor against school dropout? Procedia Social and Behavioral Sciences, 2, 1636-1643.

Liang, G., Zhang, Y., Huang, H., Shi, S., \& Qiao, Z. (2015). Professional development and student achievement: International evidence from the TIMSS data. Journal of Postdoctoral Research, 3(2), 17-31.

Liaw, E. C. (2009). Teacher efficacy of pre-service teachers in Taiwan: The influence of classroom teaching and group discussions. Teaching and Teacher Education, 25, 176-180.

Lomos, C., Hofman, R. H., \& Bosker, R. J. (2011a). Professional communities and student achievement - a meta-analysis. School Effectiveness and School Improvement, 22(2), 121-148.

Lomos, C., Hofman, R. H., \& Bosker, R. J. (2011b). The relationship between departments as professional communities and student achievement in secondary schools. Teaching and Teacher Education, 27, 722-731.

Louis, K. S., \& Marks, H. M. (1998). Does professional learning community affect the classroom? Teachers' work and student experiences in restructuring schools. American Journal of Education, 106(4), 532-575. 
Luschei, T. F., \& Chudgar A. (2011). Teacher, student achievement and national income: A cross national examination of relationships and interactions. Prospects, 41, 507-533.

Marks, G. N. (2007). Do schools matter for early school leaving? Individual and school influences in Australia, school effectiveness and school improvement. An International Journal of Research, Policy and Practice, 18(4), 429-450.

Martin, M. O., Mullis, I. V. S., Foy, P., \& Stanco, G. M. (2012). TIMSS 2011 international results in science. Chestnut Hill, MA, USA: TIMSS \& PIRLS International Study Center, Boston College.

Mikk, J., Krips, H., Saalik, O., \& Kalk, K. (2015). Relationship between student perception of teacher-student relations and PISA results in mathematics and science. International Journal of Science and Mathematics Education, $1(18)$.

Mullis, I. V. S., Martin, M. O., Foy, P., \& Arora, A. (2012a). TIMSS 2011 international results in mathematics. Chestnut Hill, MA, USA: TIMSS \& PIRLS International Study Center, Boston College.

Mullis, I. V. S., Martin, M. O., Foy, P., \& Drucker, K. T. (2012b). PIRLS 2011 international results in reading. Chestnut Hill, MA, USA: TIMSS \& PIRLS International Study Center, Boston College.

Mullis, I. V. S., Martin, M. O., Gonzalez, E., \& Kennedy, A. M. (2003). PIRLS 2001 international report. Chestnut Hill, MA, USA: TIMSS \& PIRLS International Study Center, Boston College.

Murray, C., \& Malmgrenb, K. (2005). Implementing a teacher-student relationship program in a high-poverty urban school: Effects on social, emotional, and academic adjustment and lessons learned. Journal of School Psychology, 43, 137-152.

OECD. (2009). Creating effective teaching and learning environments: First results from TALIS. Paris, France: OECD Publishing.

OECD. (2013a). PISA 2012 results: Ready to learn: Students' engagement, drive and self-beliefs (volume III). Paris, France: OECD Publishing.

OECD. (2013b). PISA 2012 results: What makes schools successful? Resources, policies and practices (volume IV). Paris, France: OECD Publishing.

OECD. (2014). TALIS 2013 results: An international perspective on teaching and learning. Paris, France: OECD Publishing.

OECD. (2016). Supporting teacher professionalism: Insights from TALIS 2013. Paris, France: OECD Publishing. 
Puchner, L. D., \& Taylor, A. R. (2006). Lesson study, collaboration and teacher efficacy: Stories from two-school based math lesson study groups. Teaching and Teacher Education, 22, 922-934.

Schleicher, A. (2016). Teaching excellence through professional learning and policy reform: Lessons from around the world, International Summit on the Teaching Profession. Paris, France: OECD Publishing.

Supovitz, J. A. (2002). Developing communities of instructional practice. Teachers College Record, 104(2), 127-146.

Vescio, V., Ross, D., \& Adams, A. (2008). A review of research on the impact of professional learning communities on teaching practice and student learning. Teaching and Teacher Education, 24, 80-91.

Vieluf, S., Kaplan, D., Klieme, E., \& Bayer, S. (2012). Teaching practices and pedagogical innovation: Evidence from TALIS. Paris, France: OECD Publishing. 


\section{$2 \cdot 3 \cdot 3$}

\section{Students' Social and Civic Competencies: Predictors of ESL}

Maša Vidmar, Ana Kozina and Tina Vršnik Perše

\section{Synopsis}

Externalising behaviours (e.g. deviant, disruptive, oppositional behaviour) are consistently shown to be risk factors for ESL. Civic competence (via participation in extracurricular activities) as well as social competence constitute protective factors. Peers also play a role. Supporting students' social and emotional adjustment early on is warranted.

\section{Summary}

ESL's possible links with social competence and problem behaviour have received some scientific attention, in the process demonstrating their relevance for dealing with ESL. Yet the topic remains largely overlooked in relevant policy briefs. The role of civic competence relative to ESL has also been neglected. The aim of this article is to review scientific studies linking social behaviour and civic competence to early school leaving and to academic achievement/failure in order to highlight the important need to support students' social and emotional adjustment as well as their civic participation from the early years on.

With regard to ESL, a review of studies shows that externalising behaviours (e.g. alcohol, drug use and abuse, disruptiveness and oppositional behaviours, delinquency, teenage parenting) are most 
consistently linked with ESL, while less research has considered internalising behaviour and social competence and even less has examined civic competence. Concerning internalising behaviour, links between ESL and depressive symptoms and mood disorders have been found. Social competence seems to be especially important for the student at risk - it appears to help build up their resilience to ESL. Evidence regarding the link between civic competence and ESL is limited, but its role has been demonstrated via extracurricular activities - participation in extracurricular and community-based activities plays a role. Peers also play a role - ESLers more often associate with deviant peers.

Despite the strong evidentiary base on the relationship with ESL (particularly for externalising behaviour), these aspects are often overlooked when addressing ESL. Thus, in order to prevent ESL it seems warranted to help build students' social and emotional adjustment and their participation in extracurricular activities from the beginning of school.

Key words: social competence, social behaviour, externalising behaviour, internalising behaviour, civic competence, extracurricular activities, early school leaving

\section{Introduction}

Social and civic competencies include a wide range of personal, interpersonal and intercultural abilities that enable individuals to participate constructively in social and school/working life in our societies that are increasingly diverse (European Commission, 2006). Social competence and several other related terms (e.g. social behaviour, social adjustment, behavioural competence) appear in similar contexts and many different definitions of them exist. For the purpose of this article, social behaviour is an overarching term within which social competence is described as efficiency in social interactions which meets short- and long-term developmental needs (Rose-Krasnor, 1997), while the lack of social competence is viewed as problem behaviour. Problem behaviour is classified in two broad categories: externalising behaviour (which includes hyperactivity, impulsiveness, attention problems, anger, opposition, aggression, disruptive and antisocial behaviour; Hinshaw, 1992; Mullin \& Hinshaw, 2007) and internalising behaviour (which includes depression, anxiety, preoccupation with physical symptoms, and social withdrawal; Eisenberg, 
Hofer, \& Vaughan, 2007; Mullin \& Hinshaw, 2007). As with social competence, there is a variety of definitions and conceptualisations for civic competence and the definition of "civic" has expanded considerably in the last decade (Haste, Bermudez, \& Carretero, 2017). Most broadly, civic competence equips individuals to fully participate in civic life, based on knowledge of social and political concepts and structures and a commitment to active and democratic participation (European Commission, 2006).

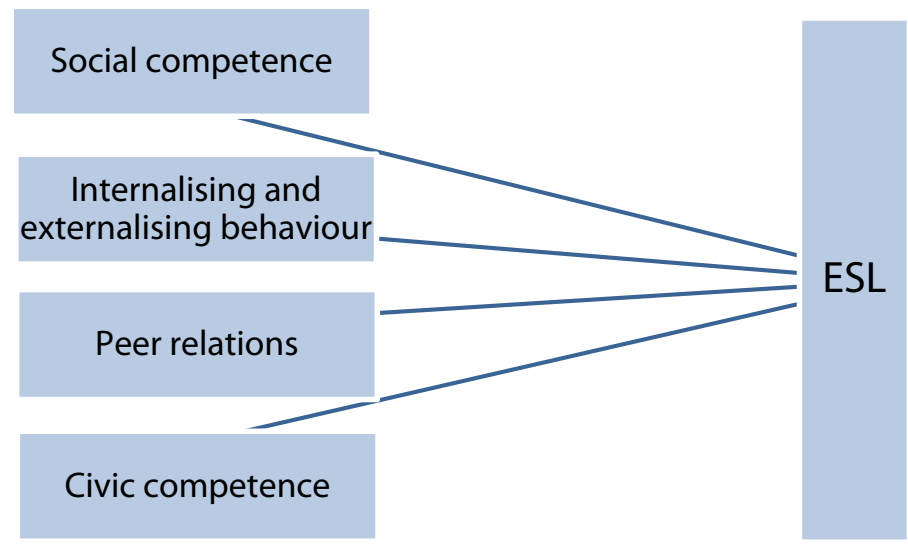

\section{Figure II. The predictors of ESL examined herein}

Social competence and problem behaviour have received considerable attention among scholars worldwide and a multitude of publications links the two domains to later (mal)adjustments (including ESL) or examines their early precursors. Civic competence is also a topic of scientific interest. Moreover, social and civic competencies are recognised as key competencies for lifelong learning also within the European reference framework (European Commission, 2006). However, as indicated by Downes (2011), these aspects (social, emotional competence) are often overlooked in the ESL policy discourse. This article aims to review scientific studies linking problem behaviour, social competence, peer relations and civic competence to ESL in order to highlight the important need to support students' social and emotional adjustment as well as their civic participation from the early years on (see Figure 11). The article also explains the mechanisms underlying these relationships. 


\section{Methodology}

This article is based on an examination of scientific articles found using the following key words: early school leaving, ESLer, drop-out AND social behaviour, social competence, problem behaviour, externalising behaviour, internalising behaviour, social adjustment, peers, civic competence, academic achievement in the EBSCOhost database. A search was also conducted using the backward procedure, while in addition we drew information from EU policy documents (e.g. European Commission).

\section{Problem behaviour and ESL}

Much research has been done on the topic of ESL and its link to problem behaviour. Most of the reviewed literature took a longitudinal approach to collecting data or comprised meta-analyses of existing literature on the topic. A literature review by PPMI (2014) for the European Commission described the competence profile of underachievers and ESLers. That profile includes poor social skills as well as being too disruptive (externalising behaviour) or too quiet, isolated (internalising behaviour) in class.

The majority of the existing research links ESL to externalising behaviours such as delinquency, discipline problems, absenteeism and deviant behaviours in and out of school (alcohol, drug use and abuse, disruptiveness and oppositional behaviours, juvenile delinquency, teenage parenting, aggression, vandalism etc.; e.g. Rumberger \& Lim, 2008; Hawkins, Jaccard, \& Needle, 2013; Jimerson, Carlson, Rotert, Egeland, \& Sroufe, 1997; Alexander, Entwisle, \& Horsey, 1997; Jimerson, Egeland, Sroufe, \& Carlson, 2000; Townsend, Fischer, \& King, 2007; Battin-Pearson et al., 2000). South, Haynie and Bose (2007) found that students who are not expressing disruptive behaviours and not misbehaving (i.e. are behaviourally engaged) are less likely to drop out of school the following year. The opposite applies to disruptiveness, which may lead to early withdrawal from school because it contributes to school problems (Jimerson et al. 1997). Absenteeism and discipline problems have also been linked to ESL (Rumberger, 2004; Rumberger \& Larson, 1998).

Within externalising behaviours, deviant behaviour's relationship with ESL has been most consistently reported in the literature (Townsend et al., 2007). Alcohol and drug use predicts ESL even when controlling for other risk factors (Garnier, Stein, \& Jacobs, 1997; Lynskey, Coffey, Degenhardt, Carlin, \& Patton, 2003; Mensch \& Kandel, 1988). In addition, 
prior delinquency has been found to predict ESL beyond the influence of poor academic achievement (Battin-Pearson et al., 200o). Parker and Asher (1987) report that, among personal factors, a disruptive behavioural profile (i.e., aggressive-hyperactive-oppositional behaviours) has repeatedly been shown to predict early withdrawal from school, even after controlling for familial and socioeconomic factors. Ensminger and Slusarcick (1992) showed that aggressive behaviours and low grades as early as first grade predicted later school dropout. On a similar note, after reviewing 25 years of previous research Rumberger and Lim (2008) concluded that engaging in any deviant behaviour (as described above) increases the risk of ESL. Two studies (Battin-Pearson et al., 2000; Newcomb et al., 2002) controlled for a host of different predictors, including prior academic achievement and family background. Both studies established that deviant behaviour at age $14 \mathrm{had}$ a significant and direct effect on ESL by age 16, and high school failure (dropout and months of missed school) in grade 12. Some studies (Bernburg \& Krohn, 2003; Hannon, 2003; Sweeten, 2006) examined involvement in the justice system and found that being arrested had a separate and generally bigger effect on ESL than delinquency. Sweeten (2006) also determined that involvement in court after being arrested was a much stronger ESL predictor than simply being arrested without any court involvement.

With regard to drug and alcohol use, in their review Rumberger and Lim (2008) established that drug and alcohol use during high school and also during middle school was associated with higher ESL in most studies examined. Alcohol, drugs and tobacco are often correlated, but two studies found that tobacco use during middle school had a direct effect on the chances of ESL, while drug (marijuana) use did not (Ellickson, Bui, Bell, \& Mcguigan, 1998; Battin-Pearson et al., 200o). Another study showed that both marijuana and tobacco use had direct effects on ESL, but marijuana use had the stronger effect (Bray, Zarkin, Ringwalt, \& Qi, 200o).

Another important indicator of deviant behaviour studied in the research literature is teen pregnancy and parenting. There is an issue of establishing a causal connection between teenage pregnancy and ESL, not knowing whether teenage pregnancy directly makes females drop out or if other unobservable factors contribute to both the pregnancy and the ESL. Rumberger and Lim (2008) report that 50 out of 62 studies found teenage parenting and childbearing to increase the odds of ESL or reduce the odds of graduating. Further, teenage parenting held more serious consequences for females than for males (Fernandez, Paulsen, \& Hirano-Nakanishi, 
1989). One of the challenges authors report on in studies of out-of-school behaviours is whether the behaviour, in this case delinquency, is causally related to ESL or whether the two behaviours are the result of a common set of underlying factors.

Research on internalising behaviour and its connection to ESL is much less extensive. Some studies linked depression to ESL through students' self-perception of academic competence. Certain researchers (Abramson, Metalsky, \& Alloy, 1989; Hankin, Abramson, \& Siler, 2001) report that depressed students have a lower and more negative self-perception. They have low self-perceived competence and, as a result, their negative perceptions of competence lead to their reduced engagement in learning activities and underachievement (Bandura, 1993; Fortier, Vallerand, \& Guay, 1995; Pajares \& Graham, 1999; Shim, Ryan, \& Anderson, 2008; Zimmerman, 2000). In the long run, children and adolescents with lower self-perceived competence and achievement are more likely to drop out of school (Alexander, Entwisle, \& Kabbani, 2001; Caprara et al., 2008; Guay, Larose, \& Boivin, 2004; Vallerand, Fortier, \& Guay, 1997). Quiroga, Janosz, Bisset, \& Morin (2013) established an association between depression and ESL. Adolescents with bigger symptoms of depression were $23 \%$ more likely to become ESLers. The relationship between depression and ESL was, however, mediated by self-perceptions of academic competence. Yet the causality in the relationship between ESL and mental health issues remains unclear. In Kaplan, Damphousse and Kaplan's (1994) North American study, 4,141 young people were tested in 7 th grade and once again as young adults. They determined a significant damaging effect of dropping out of high school on the functioning of mental health, including anxiety, depression and coping (Downes, 2011). Something similar can be said for the study by Esch and colleagues (2014) who found that mood disorders were significantly related to ESL, even after adjusting for socio-demographic factors. They report another strong and often co-occurring predictor of mood disorders is suicidal ideation. However, generally speaking, their systemic review showed that internalising disorders were reported as developing as a consequence of ESL.

The mechanisms underlying the links between ESL and problem behaviours have been explained by several authors. Jimerson et al. (2000) state that early experiences may affect self-esteem and the sense of agency that may directly influence school performance and decisions to stay in school, and may also lay the foundations for behavioural control and relationships 
with teachers and peers that further propel individuals along a path leading to ESL. Cole et al. (1996) stated that failure in social functioning may foster negative self-perceptions that are associated with depression. In relation to externalising behaviour, early aggression may lead to peer rejection which, in turn, may lead to lower self-esteem and associated internalising problems (Panak \& Garber, 1992 in Mesman, Bongers, \& Koot, 2001). Some authors (Patterson et al., 1989 in Mesman, Bongers, \& Koot, 2001) have also suggested there is a connection from early aggression to peer rejection and later delinquency.

\section{Social competence and ESL}

Fewer studies have directly examined the links between ESL and social competence than have examined problem behaviours. Elias and Haynes (2008) reported that social competence is extremely important in determining school success among an at-risk population as social competence was significantly related to academic performance. Just as high social competence predicts positive outcomes, students lacking in social competence are typically aggressive, rejected by their peers, and unable to regulate their emotions (Masten \& Coatsworth, 1998). Many studies (Townsend et al., 2007; Rumberger \& Lim, 2008) show that peer rejection and antisocial behaviours increase the risk for ESL, allowing the conclusion that a lack of social competence increases the risk of ESL. Lane, Pierson and Givner (2004) more specifically report that secondary students with deficiencies in their academic, behavioural and social skills or whose abilities differ from the norm are at risk for short- and long-term negative outcomes, including ESL. Tirabassi (2013) conducted a study in which the general relationship between the protective factor of social competence and its relationship to previously identified risk factors for ESL was examined. It was concluded that students who display strengths in social competence increase their resilience to ESL. On that basis, they concluded that students low in social competence in addition to low academic achievement have a great risk of ESL. Carter (1998) also conducted a study to determine which relationships exist between the social competence skills of at-risk seventh graders who remain in school and at-risk seventh graders who drop out of school. The research confirmed there was a key difference in the social competence scores between the two groups, with the dropout group having lower social competence than the non-dropout group. Frey, Balzer and Ruppert (2014) observed that young people with a higher ESL risk assessed their social 
competencies as being lower than those with a lower ESL risk. To sum up, social competence seems to play a protective role, particularly for students at risk; yet more extensive research must be conducted in the future in this area.

As low academic achievement is one of the strongest and most consistent ESL predictors, we briefly review the large body of research linking academic achievement to social behaviour. The link from academic achievement to social competence and to problem behaviour (especially externalising behaviour) is demonstrated in many studies, but not in all; most studies found negative longitudinal effects of externalising behaviour on academic achievement (for a review, see Battin-Pearson, 2000; Vidmar, in press; Vidmar, 2011). Research evidence shows that externalising behaviour has a negative effect on academic achievement particularly at the start of schooling, while in later years the relationship becomes reciprocal (Chen, Rubin, \& Li, 1997; Masten et al., 2005; van Lier et al., 2012; Vidmar, in press; Welsh, Parke, Widaman, \& O’Neil, 2001). Reciprocal relations between social competence and academic achievement were established in some studies (e.g. Vidmar, 2011), while for problem behaviour the relationship was unidirectional (early problem behaviour predicted later academic achievement, but not vice versa; e.g. Vidmar, in press). The link between internalising behaviour and academic achievement has less consistently been found and is under-researched (for exceptions, see van Lier et al., 2012; Vidmar, 2011). Thus, social competence and low problem behaviour function as a predecessor of academic competence, at least to some degree. Mindes (2015) stated that children who managed to enhance their socio-emotional competence show an improved academic performance and social behaviour, reduced behavioural problems, and less emotional stress.

\section{Peers and ESL}

The role of peer networks has received relatively little attention in the statistical work conducted with regard to delinquency and ESL (Audas \& Willms, 2001). Authors believe this is largely due to the difficulty of meaningfully quantifying these aspects of a young person's life. Traag (2012) stated similarly, noting that studies on the relevance of peers for ESL are quite limited.

Ellenbogen and Chamberland (1997) examined the peer networks of at-risk youths. They identified three trends: First, actual ESLers and future ESLers have more friends who have dropped out. The second trend was that future ESLers tend to be rejected by their school peers and, the third, at-risk 
individuals tend to lack integration into their school's social network. We found quite a few studies making similar conclusions (Parker \& Asher, 1987; Kupersmidt, Coie, \& Dodge, 1990). Cairns, Cairns and Neckerman's (1989) longitudinal study of 475 USA students showed that for both boys and girls in seventh grade school drop-outs affiliated with peers who themselves later dropped out of school. Another study by Vitaro, Larocque, Janosz, and Tremblay (2001) among Caucasian boys in Canada showed that associating with deviant friends (i.e. friends who had been arrested by the police, been a member of a gang and/or had considered leaving school) did have a significant impact on high school ESL. On a similar note, a study by Ream and Rumberger (2008) revealed that the number of drop-out friends significantly increased the risk of school drop-out in grade 12. Moreover, a review of different studies by Rumberger and Lim (2008) found that having deviant friends - friends who engage in criminal behaviour, or friends who have dropped out - increases the chances of ESL. There appear to be many more studies in support of that fact (Alpert \& Dunhan, 1986; Elliott \& Voss, 1974). There are also many studies showing that being bullied increases the chances of avoiding school or even leaving school early (Cornell, Huang, Gregory \& Fan, 2013; Downes, 2011). Traag (2012) reports that both popularity and friendship correlate with ESL. Like others before them, they also found that being popular among future ESLers as well as being friends with future ESLers are both associated with a greater risk of ESL.

Kelly (1993) identified three ways that peer groups become involved in the disengagement process. The first are conflicts with other students leading to expulsion; the second are the dissociative feelings with school peers that are the cause and motivation for someone to quietly withdraw from that environment; and third, attributing greater importance to relationships and maybe even pregnancy than to school.

On the other hand, positive peer relationships can be a protective factor supporting a student's academic pursuits, with studies revealing that peers can serve as effective socialisation agents for school engagement and motivation (Hymel \& Ford, 2014). Since there are many studies showing school engagement is a big protective factor against ESL, we may conclude the same with regard to positive peer relations.

\section{Civic competence and ESL}

Not many studies directly link ESL with civic competence, although the two domains could related and further studies are called for. Youniss et al. 
(2002) states that the elements constituting civic competence and citizenship are open to debate. As mentioned, many different definitions can be found; they include knowledge of the structure and functions of government; attitudes to proper political behaviour; and behaviour itself, such as voting, commitment to society, and, of late, a host of actions that comprise participation in civil society (e.g. Kymlicka \& Norman, 1994). Starks (2010) argues that civil knowledge and participation are vital for sustaining an ordered society (e.g., voting, employment, supporting the local economy, and going to school with the intention to graduate from high school).

Extracurricular activities have long been identified as one of the earliest manifestations of civic engagement (Sherrod, Flanagan, \& Youniss, 2002; Yates \& Youniss, 1998). Youniss, McLellan and Yates (1997) pointed out that such participation allows youth to explore the roles and processes central to the successful development of adult civic engagement. They believe that involvement in extracurricular activities provides adolescents with opportunities to appreciate the relationship between the rights and obligations of citizens, and to learn democratic principles, such as solidarity, tolerance, intergroup understanding, and interdependence (Flanagan \& Faison, 2001). Activity participation has been linked to higher academic achievement and educational attainment (Cooper, Valentine, Nye, \& Lindsay, 1999; Fletcher, Nickerson, \& Wright, 2003; Otto, 1975). Adolescents involved in extracurricular activities have also been shown to have more academically inclined friends and fewer friends who exhibit risky behaviour, such as skipping school and using drugs (Eccles \& Barber, 1999), which are all risk factors for ESL. Mahoney and Cairns (1997) found that involvement in extracurricular activities significantly reduced ESL rates, especially among at-risk youth. Participation in extracurricular and community-based activities assists adolescents in developing their social skills and acquiring new prosocial peer relationships (Eccles \& Barber, 1999), which are all protective factors regarding ESL. Obradović and Masten (2007) report that active participation has been linked to higher academic achievement and educational attainment (Fletcher et al. 2003).

Starks (2010) highlights the importance of civic education in relation to student school dropout as being aware of the importance of a high school diploma. It is stated that students who lack civic knowledge and education are eroding the importance of a high school diploma, which then leads them to the alternative of ESL. The author believes that one way to reduce the high ESL levels is to connect education with civic responsibility. 


\section{Conclusion}

Social competence, problem behaviour and to some extent civic competence have a long-lasting research tradition. In relation to ESL, the review of studies shows that externalising behaviours (e.g. alcohol, drug use and abuse, disruptiveness and oppositional behaviours, delinquency, teenage parenting) are most consistently linked with ESL, while there is less research on internalising behaviour and social competence and even less on civic competence. Concerning internalising behaviour, ESL's links with depressive symptoms and mood disorders have been established. Social competence seems to be especially important for a student at risk - it seems to help build their resilience to ESL. Evidence regarding the link between civic competence and ESL is limited, but its role has been demonstrated via extracurricular activities - participation in extracurricular and community-based activities plays a role. Peers also play a role - ESLers more often associate with deviant peers and other ESLers.

It is also important to note that externalising and internalising behaviours, low social competence, peer relations, and achievement problems strongly correlate with each other. Despite the solid evidentiary base on the relationship with ESL (especially for externalising behaviour), these aspects are often overlooked in policy discourse dealing with ESL. In the future, efforts to address ESL should take this into consideration.

\section{References}

Abramson, L. Y., Metalsky, G. I., \& Alloy, L. B. (1989). Hopelessness depression: A theory-based subtype of depression. Psychological Review, 96, 358-372.

Alexander, K. L., Entwisle, D. R., \& Kabbani, N. S. (2001). The dropout process in life course perspective: Early risk factors at home and school. Teachers College Record, 103, 760-822.

Alpert, G., \& Dunham, R. (1986). Keeping academically marginal youths in school: A prediction model. Youth and Society, 17, 346-361.

Audas, R., \& Willms, J. D. (2001). Engagement and dropping out of school: A life course perspective. (Unpublished working paper for the Applied Research Branch), Strategic Policy, Human Resources Development, Canada.

Bandura, A. (1993). Perceived self-efficacy in cognitive development and functioning. Educational Psychologist, 28, 117-148. 
Battin-Pearson, S., Newcomb, M. D., Abbott, R. D., Hill, K. G., Catalano, R. F., \& Hawkins, D. (200o). Predictors of early high school dropout: A test of five theories. Journal of Educational Psychology, 92, 568-582.

Bernburg, J. G., \& Krohn, M. D. (2003). Labeling, life chances, and adult crime: The direct and indirect effects of official intervention in adolescence on crime in early adulthood. Criminology, 41, 1287-1318.

Bray, J. W., Zarkin, G. A., Ringwalt, C., \& Qi, J.F. (200o). The relationship between marijuana initiation and dropping out of high school. Health Economics, 9, 9-18.

Cairns, R. B., Cairns, B. D., \& Neckerman, H. J. (1989). Early school dropout: Configurations and determinants. Child Development, 6o, 1437-1452.

Caprara, G. V., Fida, R., Vecchione, M., Del Bove, G., Vecchio, G. M., Barbaranelli, C., \& Bandura, A. (2008). Longitudinal analysis of the role of perceived self-efficacy for self-regulated learning in academic continuance and achievement. Journal of Educational Psychology, 100, 525-534.

Carter, J. C. (1998). The relationship between at-risk students' resilience and dropout behavior (dissertation). University of North Carolina, Chapel Hill, North Carolina.

Chen, X., Rubin, K. H., \& Li, D. (1997). Relation between academic achievement and social adjustment: Evidence from Chinese children. Developmental Psychology, 33(3), 518-525.

Cole, D. A., Martin, J. M., Powers, B., \& Truglio, R. (1996). Modeling causal relations between academic and social competence and depression: A multitrait-multimethod longitudinal study of children. Journal of Abnormal Psychology, 105, 258-270.

Cooper, H., Valentine, J. C., Nye, B., \& Lindsay, J. J. (1999). Relationships between five after-school activities and academic achievement. Journal of Educational Psychology, 91, 369-378.

Cornell, D., Huang, F., Gregory, A. and Fan, X. (2013). Perceived prevalence of teasing and bullying predicts high school dropout rates. Journal of Educational Psychology, 105(1), 138-149.

Downes, P. (2011). The neglected shadow: European perspectives on emotional supports for early school leaving prevention. The International Journal of Emotional Education, 3(2), 3-36.

Eccles, J. S., \& Barber, B. L. (1999). Student council, volunteering, basketball, or marching band: What kind of extracurricular involvement matters? Journal of Adolescent Research, 14, 10-43. 
Eisenberg, N., Hofer, C., \& Vaughan, J. (2007). Effortful control and its socioemotional consequences. In J. J. Gross (Ed.), Handbook of Emotion Regulation (pp. 287-306). New York, USA: The Guilford Press.

Elias, M. J., \& Haynes, N. M. (2008). Social competence, social support, and academic achievement in minority, low-income, urban elementary school children. School Psychology Quarterly, 23(4), 474-495.

Ellenbogen, S., \& Chamberland, C. (1997). The peer relations of dropouts: A comparative study of at-risk and not at-risk youths. Journal of Adolescence, $20,355-67$.

Ellickson, P., Bui, K., Bell, R., \& Mcguigan, K. A. (1998). Does early drug use increase the risk of dropping out of high school? Journal of Drug Issues, 28(2), 357-380.

Elliott, D. S., \& Voss, H. L. (1974). Delinquency and dropout. Lexington, MA: Lexington Books.

Ensminger, M. E., \& Slusarcick, A. L. (1992). Paths to high school graduation or dropout: A longitudinal study of a first-grade cohort. Sociology of Education, 65, 95-113.

Esch, P., Bocquet, V., Pull, C., Couffignal, S., Lehnert, T., Graas, M., et al. (2014). The downward spiral of mental disorders and educational attainment: A systematic review on early school leaving. BMC Psychiatry, 14(232).

European Commission (2006). Recommendation of the European Parliament and of the Council on key competences for lifelong learning (2006/962/ EC). Retrieved from http://eur-lex.europa.eu/legal-content/EN/TXT/ $\mathrm{PDF} /$ ?uri=CELEX:32006Ho962\&from $=\mathrm{EN}$

Fernandez, R. M., Paulsen, R., \& Hirano-Nakanishi, M. (1989). Dropping out among Hispanic youth. Social Science Research, 18, 21-52.

Flanagan, C. A., \& Faison, N. (2001). Youth civic development: Implications of research for social policy and programs. Social Policy Report, 15, 3-14.

Fletcher, A. C., Nickerson, P., \& Wright, K. L. (2003). Structured leisure activities in middle childhood: Links to well-being. Journal of Community Psychology, 31, 641-659.

Fortier, M. S., Vallerand, R. J., \& Guay, F. (1995). Academic motivation and school performance: Toward a structural model. Contemporary Educational Psychology, 20, 257-274.

Frey, A., Balzer, L., \& Ruppert, J. J. (2014). Transferable competences of young people with a high dropout risk in vocational training in Germany. 
International Journal for Educational and Vocational Guidance, 14(1), 119-134.

Garnier, H. E., Stein, J. A., \& Jacobs, J. K. (1997). The process of dropping out of high school: A 19-year perspective. American Educational Research Journal, 34, 395-419.

Guay, F., Larose, S., \& Boivin, M. (2004). Academic self-concept and educational attainment level: A ten-year longitudinal study. Self and Identity, 3, 53-68.

Hankin, B. L., Abramson, L. Y., \& Siler, M. (2001). A prospective test of the hopelessness theory of depression in adolescence. Cognitive Therapy and Research, 25, 607-632.

Hannon, L. (2003). Poverty, delinquency, and educational attainment: Cumulative disadvantage or disadvantage saturation? Sociological Inquiry, 73, 575-594.

Haste H., Bermudez A., \& Carretero M. (2017). Culture and civic competence. In García-Cabrero B., Sandoval-Hernández A., Treviño-Villareal E., Ferráns S. D., Martínez M .G. P. (Eds.) Civics and Citizenship. Moral Development and Citizenship Education. SensePublishers, Rotterdam.

Hawkins, R. L., Jaccard, J., \& Needle, E. (2013). Nonacademic factors associated with dropping out of high school: Adolescent problem behaviors. Journal of the Society for Social Work and Research, 4(2), 58-75.

Hinshaw, S. P. (1992). Externalizing behavior problems and academic underachievement in childhood and adolescence: Causal relationships and underlying mechanisms. Psychological Bulletin, 111(1), 127-155.

Hymel, S., \& Ford, L. (2014). School completion and academic success: The impact of early social-emotional competence. Encyclopedia on Early Childhood Development.

Jimerson, S., Egeland, B. L., Sroufe, A., \& Carlson, B. (200o). A prospective longitudinal study of high school dropouts examining multiple predictors across development. Journal of Social Psychology, 38(6), 525-549.

Kaplan, D. D., Damphousse, J. R., \& Kaplan, H. B. (1994). Mental health implications of not graduating from high school. Journal of Experimental Education, 62, 105-123.

Kelly, D. M. (1993). Last chance high: How girls and boys drop into and out of alternative schools. New Haven, CT: Yale University Press.

Kupersmidt, J. B., Coie, J. D., \& Dodge, K. A. (1990). The role of poor peer relationships in the development of disorders. In S. R. Asher. \& J. D. Coie 
(Eds.), Peer Rejection in Childhood, New York: Cambridge University Press.

Kymlicka, W., \& Norman, W. (1994). Return of the citizen: A survey of recent work on citizenship theory. Ethics, 104, 352-381.

Lane, K. L., Pierson, M. R., \& Givner, C. C. (2004). Secondary teachers' views on social competence: Skills essential for success. The Journal of Special Education, 38(3), 174-186.

Lynskey, M. T., Coffey, C., Degenhardt, L., Carlin, J. B., \& Patton, G. (2003). A longitudinal study of the effects of adolescent cannabis use on high school completion. Addiction, 98, 685-692.

Mahoney, J. L., \& Cairns, R. B. (1997). Do extracurricular activities protect against early school dropout? Developmental Psychology, 33, 241-253.

Masten, A. S., \& Coatsworth, J. D. (1998). The development of competence in favorable and unfavorable environments: Lessons from research on successful children. American Psychologist, 53(2), 205-220.

Masten, A. S., Roisman, G. I., Long, J. D., Burt, K. B., Obradovic, J., Riley, J. R., et al. (2005). Developmental cascades: Linking academic achievement and externalizing and internalizing symptoms over 20 years. Developmental Psychology, 41(5), 733-746.

Mensch, B. S., \& Kandel, D. B. (1988). Dropping out of high school and drug involvement. Sociology of Education, 61, 95-113.

Mesman, J., Bongers, I. L., \& Koot, H. M. (2001). Preschool developmental pathways to preadolescent internalizing and externalizing problems. Journal of Child Psychology and Psychiatry, 42(5), 679-689.

Mindes, G. (2015). Pushing up the social studies from early childhood education to the world. Young Children, 7o(3), 10-15.

Mullin, B. C., \& Hinshaw, S. P. (2007). Emotion regulation and externalizing disorders in children and adolescents. In J. J. Gross (Ed.), Handbook of Emotion Regulation (pp. 523-541). New York, USA: The Guilford Press.

Newcomb, M. D., Abbott, R.D., Catalano, R. F., Hawkins, J. D., Battin-Pearson, S., \& Hill, K. (2002). Mediational and deviance theories of late high school failure: Process roles of structural strains, academic competence, and general versus specific problem behaviors. Journal of Counseling Psychology, 49, 172-186.

Obradovič, J., \& Masten, A. S. (2007). Developmental antecedents of young adult civic engagement. Applied Developmental Science, 11(1), 2-19. 
Otto, L. B. (1975). Extracurricular activities in the educational attainment process. Rural Sociology, 40, 162-176.

Pajares, F., \& Graham, L. (1999). Self-efficacy, motivation constructs, and mathematics performance of entering middle school. Contemporary Educational Psychology, 24, 124-139.

Parker, J. G. \& Asher, S. R. (1987). Peer relations and later personal adjustment, are low accepted children at risk? Psychological Bulletin, 10, 357-389.

PPMI (Public Policy and Management Institute). (2014). Study on the effective use of early childhood education and care in preventing early school leaving. Annex 1. Literature review. Luxembourg: Publications Office of the European Union.

Quiroga, C.V., Janosz, M., Bisset, S., \& Morin, A. J. S. (2013). Early adolescent depression symptoms and school dropout: Mediating Processes involving self-reported academic competence and achievement. Journal of Educational Psychology, 105(2), 552-560.

Rose-Krasnor, L. (1997). The nature of social competence: A theoretical review. Social Development, 6, 111-135.

Rumberger, R. W. (2004). Why students drop out of school. In G. Orfield (Ed.), Dropouts in America: Confronting the graduation rate crisis (pp. 131-156). Cambridge, MA: Harvard University Press.

Rumberger, R. W., \& Larson, K. A. (1998). Student mobility and the increased risk of high school dropout. American Journal of Education, 107, 1-35.

Rumberger, R. W., \& Lim, S. A. (2008). Why students drop out of school: A review of 25 years of research. Santa Barbara, CA: California Dropout Project Report.

Sherrod, L. R., Flanagan, C., \& Youniss, J. (2002). Dimensions of citizenship and opportunities for youth development: The what, why, when, where, and who of citizenship development. Applied Developmental Science, 6, 264-272.

Shim, S. S., Ryan, A. M., \& Anderson, C. J. (2008). Achievement goals and achievement during early adolescence: Examining time-varying predictor and outcome variables in growth-curve analysis. Journal of Educational Psychology, 100, 655-671.

South, S. J., Haynie, D. L., \& Bose, S. (2007). Student mobility and school dropout. Social Science Research, 36, 68-94.

Starks, C. F. (2010). Connecting civic education to civil right and responsibility: A strategy for reducing high school dropout among African American 
students. (Master's thesis). California State University, Sacramento, California.

Sweeten, G. (2006). Who will graduate? Disruption of high school education by arrest and court involvement. Justice Quarterly, 23, 462-480.

Tirabassi, A. (2013). Relationship between social competence and student dropout. ME thesis. Retrieved from https://minds.wisconsin.edu/handle/1793/67284

Townsend, L., Fischer, A. J., \& King, G. (2007). A systematic review of the relationship between high school dropout and substance use. Clinical Child and Family Psychology, 10, 295-315.

Traag, T. (2012). Early school-leaving in the Netherlands. A multidisciplinary study of risk and protective factors explaining early school-leaving. Statistics Netherlands, Grafimedia.

Vallerand, R. J., Fortier, M. S., \& Guay, F. (1997). Self-determination and persistence in a real-life setting: Toward a motivational model of high school dropout. Journal of Personality and Social Psychology, 72, 1161-1176.

van Lier, P. A. C., Vitaro, F., Barker, E. D., Brendgen, M., Tremblay, R. E., \& Boivin, M. (2012). Peer victimization, poor academic achievement, and the link between childhood externalizing and internalizing problems. Child Development, 83, 1775-1788.

Vidmar, M. (2011). Socialna kompetentnost in učna uspešnost v prvih razredih osnovne šole [Social competence and academic achievement in the first Grades]. Šolsko polje [School Field], 22(1-2), 31-54.

Vidmar, M. (in press). Vedenjske težave in učna uspešnost [Problem behaviour and academic achievement]. Ljubljana: Pedagoški inštitut, Digitalna knjižnica.

Vitaro, F., Larocque, D., Janosz, M., \& Tremblay, R. E. (2001). Negative social experiences and dropping out of school. Educational Psychology, 21(4), 401-414.

Welsh, M., Parke, R. D., Widaman, K., \& O’Neil, R. (2001). Linkages between children's social and academic competence: A longitudinal analysis. Journal of School Psychology, 39(6), 463-481.

Yates, M., \& Youniss, J. (1998). Community service and political identity development in adolescence. Journal of Social Issues, 54, 495-512.

Youniss, J., Bales, S., Christmas-Best, V., Diversi, M., McLaughlin, M., \& Silbereisen, R. (2002). Youth civic engagement in the twenty-first century. Journal of Research on Adolescence, 12(1), 121-148. 
Youniss, J., McLellan, J. A. \& Yates, M. (1997). What we know about engendering civic identity. American Behavioral Scientist, 40, 620-631.

Zimmerman, B. J. (2000). Self-efficacy: An essential motive to learn. Contemporary Educational Psychology, 25, 82-91. 


\section{$2 \cdot 3 \cdot 4$}

\section{Mental Health as a Risk Factor for ESL: Diagnostics, Prevention, Intervention}

Ana Kozina

\section{Synopsis}

Mental health problems (e.g. anxiety, depression) are some of the risk factors for ESL and, by focusing on mental health prevention and intervention programmes in the school environment, we can reduce the many negative consequences poor mental health has on both the individual and community levels.

\section{Summary}

ESL is a complex long-term process involving multiple environmental, psychological and academic factors. There is increasing recognition of the need to recognise the role of mental health in educational processes (including in ESL). Studies investigating whether common mental disorders indeed constitute relevant risk factors for ESLers have provided little consistent evidence. In the paper, we focus on internalisation problems (e.g. anxiety and depression) and externalisation problems (e.g. aggression) as well as the mechanisms linking them to lower academic achievement and ESL. The underlying mechanisms of mental health problems associated with low achievement are related to lower connectedness to school, negative attitudes to school, and peer rejection (in case of aggression and disruptive behaviour disorders), lower engagement through impaired mastery beliefs and negative emotionality (as in the case of depression) and difficulties with cognitive functioning through reduced memory 
functions and the impact of worries on the cognitive system (as in the case of anxiety). The relationship between mental health problems and school performance is two-directional. Mental health problems can precede problems related to school performance and, on the other hand, difficulties in school can result in various problems with mental health. In the paper, the importance of early recognition, assessment and later on prevention and intervention (on universal, selective and individual levels) is stressed. The findings are based on a review of the relevant literature. The need to clearly establish a relationship between anxiety and ESL is especially relevant since the research shows that anxiety levels are on the increase in school-aged populations (Kozina, 2014; Twenge, 2000). The studies in the EU (Angermeyer et al., 2004) which reveal that a high proportion (13.6\%) of 18-year-olds have anxiety disorders make the topic even more pertinent.

Key words: mental health, internalization difficulties, externalization difficulties, school climate, depression, anxiety, aggression, academic achivement

\section{Introduction}

Mental health plays a significant role in children's school success. Problems associated with school performance (including early school leaving - ESL) are associated with emerging or existing mental health problems (DeSocio \& Hootman, 2004). On one hand, there is growing recognition of the need to combine mental health and educational processes such as ESL, e.g. the need to conceptualise ESL prevention as an issue related to mental health (Downes, 2011). On the other hand, according to Downes (2011) the importance of mental health issues has so far been neglected in ESL research. In the paper, we will look into these relations in greater detail and address the possibilities of using mental health prevention as a tool for preventing ESL. The most frequently mentioned mental health problems regarding school difficulties are externalisation disorders (disruptive behaviour disorders: attention deficit disorders, oppositional deviant disorder and conduct disorder) and internalisation disorders (anxiety and depression). In this contribution, we will focus more on internalisation problems since they often go unrecognised in the school setting (Hishinuma, Chang, McArdle, \& Hamagami, 2012) and are therefore also often unnoticed in the area of ESL prevention. Many anxious youth remain unidentified and more than $80 \%$ 
remain untreated and, even when in health services, they are less likely to get help compared to youth with externalisation difficulties (Fox, Herzig, Colognori, Stewart, \& Warner, 2014). The topic's relevance is stressed even more since mental health problems (especially anxiety) are on the rise (DeSocio \& Hootman, 2004; Kozina, 2014).

\section{Methodology}

Literature was selected based on its relevance and narrow focus on the issue of mental health and ESL. The literature review was made using a scientific literature search (database PychArticles (EBSCO-HOST)). The following key words were used: mental health; early school leaving; drop-out; academic achievement; anxiety; depression; aggression. We used relevant scientific monographs and handbooks on the topic of mental health (also through a backward search).

\section{Mental health and school functioning (their role in ESL)}

A diagnosis of psychopathology in adolescence is frequently preceded by difficulties in academic and social functioning (Boyce, Essex, Woodward, Measelle, Ablow, \& Kupfer, 2002). Roderick and colleagues (Roderick, Eggert, Thomson, Randell, \& Pike, 2002) studied truancy and identified mental health problems as factors contributing to poor school attendance. Similarly, Eggert and colleagues (2002) identified an increased risk of depression among disengaged students prone to ESL. The relationship between mental health problems and school performance is two-directional. Mental health problems can precede problems related to school performance. This is usually related to physiological and cognitive changes due to mental health issues that interfere with the learning process (for instance, insomnia in depression, cognitive preoccupation with worries in anxiety) (Hishinuma et al., 2012). This means that a mental disorder can in itself significantly interfere with cognitive functioning and also be related to learning difficulties and ESL. On the other hand, difficulties in school can result in various problems with mental health. School is an important domain in which children achieve developmental milestones (DeSocio \& Hootman, 2004) and therefore a lack of success in this domain can lead to different mental health issues especially for students who attribute great significance to their academic achievement (Hishinuma et al., 2012). For instance, ESL students are more prone to different mental health problems (DeSocio \& 
Hootman, 2004) even when controlling for their mental health status prior to ESL (Kaplan, Damphouse, \& Kaplan, 1994). Either way, the persistence of poor school functioning combined with a mental health problem can lead to school disengagement and ESL.

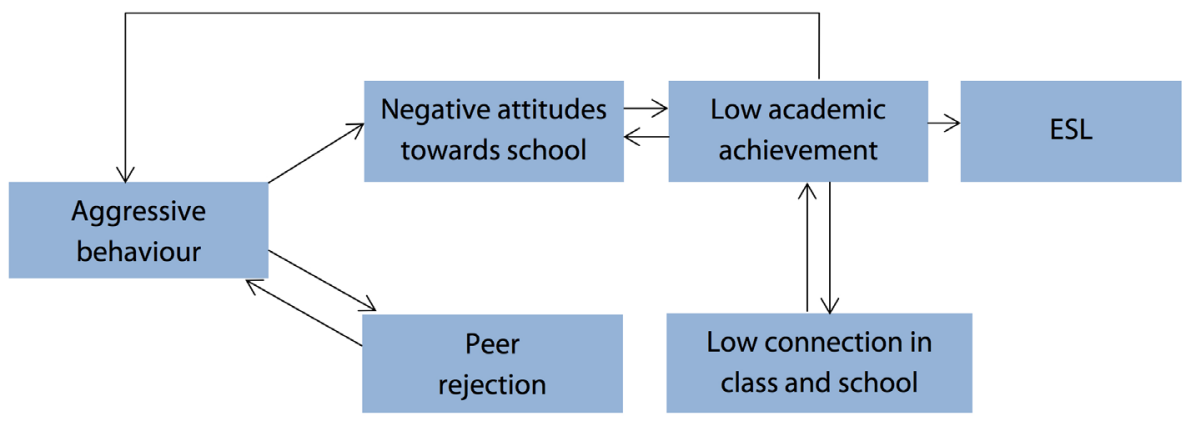

Figure 12. Summary of the research findings - externalisation difficulties and ESL

The most commonly mentioned mental health problems associated with school difficulties (and school failure) are externalisation disorders (disruptive behaviour disorders: attention deficit disorders, oppositional deviant disorder and conduct disorder) and internalisation disorders (anxiety and depression). As mentioned, we will focus more on depression and anxiety, but first we should point out that disruptive behaviour disorders (with aggression in their core) are related to problems in school functioning. Children with this type of disorders usually have difficulties with transitions, fitting into peer groups and forming friendships, which can lead them to associate more with deviant peer groups that are also prone to truancy and ESL (DeSocio \& Hootman, 2004; Battin-Pearson, Newcomb, Abbot, Hill, Catalano, \& Hawkins, 200o). Research shows that aggressive behaviour in early childhood serves as a significant predictor of negative attitudes to school, which is also strongly related to lower academic achievement (Huesmann, 1994). Low academic achievement has consistently been one of the strongest predictors of dropping out of high school (Battin-Pearson et al., 2000). Further, the associations between aggression and the school climate (Flannery, Vazsonyi, \& Waldman 2007) as well as between aggression and academic achievement (McEvoy \& Welker 2000) are significant even when SES is controlled for. Indeed, these variables often reinforce each other. For instance, pupils who exhibit more aggression at an early age also develop a negative attitude to school, resulting in lower 
achievement (Zhou, Main, \& Wang 2010), and are more commonly rejected by their peers (Flannery et al., 2007; Huesmann, 1994). Rejection by one's peers is significantly and consistently associated with lower connectedness to the class, which is followed by low involvement in class and school activities (Buhs, Ladd, \& Herald 2006; Ladd, Kochenderfer, \& Coleman 1997; Wentzel \& Asher 1995), which ultimately significantly predicts low academic achievement (Buhs et al., 2006; Ladd et al., 1997; Vandell \& Hembree 1994) as seen in the diagram below.

Even though the depressive symptoms are not as noticeable as disruptive behaviour, they have a strong impact on one's cognitive functioning and academic achievement. The school performance of depressed students is largely affected by poor concentration, distractibility, insomnia and daytime sleepiness, irritability and low self-esteem (DeSocio \& Hootman, 2004; Hishinuma et al., 2012). Studies have shown that self-reported depressive symptoms are negatively associated with self-reported academic competence and achievement and that these factors can undermine school performance (Quiroga et al., 2013). The relationship is mediated by students' self-perception of academic competence. Even though ESL is a complex long-term process in which psychological factors (and mental health) play an important role, the mechanisms that link depression with ESL remain to be elucidated in research (Quiroga et al., 2013). Quiroga and colleagues (Quiroga et al., 2013), for instance, established that self-reported depression symptoms in Grade 7 increased the risk of ESL in later adolescence. Depressive individuals are prone to pessimistic ways of thinking with impaired mastery beliefs, leading them to believe they will not cope with school (Quiroga et al., 2013). Cross-sectional studies (Assarnow et al., 2005; Reinherz, Frost, \& Pakiz, 1991) have shown that depressed youth are more likely to interrupt schooling. Longitudinal research shows some contradicting findings, namely, that depressive youth are more likely to leave school early but, when controlled for other ESL risk factors such as low academic achievement and family background, the path was no longer significant. It is therefore not yet clear whether depression has an effect on its own or depression is simply a result of the accumulation of various other risk factors (Ferguson \& Woodwarth, 2002). Regarding this issue, Hishinuma and colleagues (2012) conducted a longitudinal study and established that depressive symptoms undermine academic success and not the other way around, indicating that depression on its own plays a significant role in education underachievement (and potential ESL). Another explanation is a 
link between depression and the low engagement of students. The negative emotionality that is characteristic of depressive students also impact engagement, e.g. by lowering positive emotions towards school and thereby diminishing the emotional component of engagement (Wang \& Peck, 2013). Hishinuma and colleagues (2012) pointed out that emphasis must be given to screening, identifying and treating depressive symptoms and disorders, not only to reduce the ill effects but also to avoid low academic achievement.

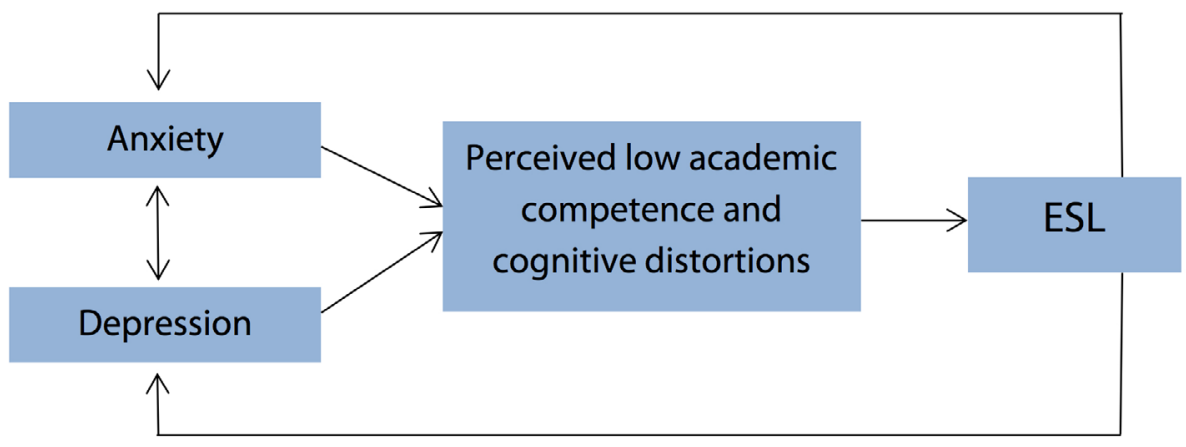

Figure 13. Summary of findings - internalisation disorders and ESL

Depression and anxiety are frequently comorbid (sharing the common component of negative affect with increased activation in anxiety and decreased activation in depression (for details, see the Tripartite model of anxiety and depression, Chorpita, 2002)). Both anxiety disorders and depressive disorders contribute to school avoidance and academic underachievement (Woodworth \& Fergusson, 2001). Anxiety is a cognitive, emotional, behavioural and physiological response of an individual experiencing a feeling of danger or threat, the cause of which they are not aware of (Fonseca \& Perrin, 2001). High levels of anxiety, notably where clinical symptoms are expressed, interfere significantly with children's adaptive functioning, social competence, peer relations and social adjustment (Last, Hansen, \& Franco, 1997; Schwartz et al., 2006), and when present in childhood follow a chronic course, and continue into adulthood (Ialongo et al., 1996; Kim-Cohen et al., 2003; Woodworth \& Fergusson, 2001). Anxiety is negatively correlated with educational achievement (Duchesne \& Ratalle, 2010; Normandeau \& Guay, 1998) in both clinical and non-clinical samples (Mazzone et al., 2007) and different age groups, i.e. at the primary and secondary levels of education (Mazzone et al., 2007). Students 
with higher levels of anxiety find it more difficult to learn new academic content (also related to learning difficulties), which may also be a result of reduced memory functions (caused by anxiety), making it difficult for them to complete cognitive tasks (Prevatt, Welles, Li, \& Proctor, 2010). Cognitive theories highlight negative automatic thoughts (in the form of worries) that occur both during the learning process and the process of examination ${ }^{\mathrm{I}}$ as particularly disturbing (Anić, 2009). Studies have reported that $10 \%$ to $20 \%$ of underachieving students suffer from anxiety. Underachieving students are students who do not reach their potential in spite of adequate opportunities and abilities (they do not have learning difficulties). Studies have revealed that the influence can run in both directions. Reduced academic achievement leads to increased anxiety and, in turn, this increased anxiety results in reduced achievement because anxiety affects the processes of thinking and learning. Reduced academic achievement may lead to greater anxiety also due to the high expectations of parents. Parents' expectations can occur in the form of negative thoughts (for instance, parental expectation in the form of the thought I have to get a good grade to get to a better school occupies the students while taking an exam) which occupy the working memory, thereby hindering the cognitive process (Hribar \& Magajna, 2011). As mentioned, anxiety causes difficulties in learning even when learning deficits are not present. Thus, in cases where anxiety occurs among students with deficits in learning this poses an additional burden on cognitive processes, thereby further disrupting the acquisition of knowledge (Nelson \& Harwood, 2011). Thus, high anxiety creates both short-term consequences (for instance, it interferes with the processes of reading and numeracy by burdening working memory) and long-term ones in the sense of poorer academic achievement and ESL (Hribar \& Magajna, 2011).

The increase in anxiety holds significant implications for the mental and physical health of whole generations. It has been proven many times that high anxiety can, among others, cause intense psychosocial impairment (Silverman \& Treffers, 2001) and lead to major depression, a wide variety of physical illnesses, impaired cognitive performance, marital problems and substance abuse (Twenge, 200o). 


\section{Diagnostics and intervention}

Recognition of the early markers of psychological difficulties and distress and therefore compromised school functioning (with a higher risk of ESL) could prompt the delivery of mental health promotion and prevention activities to avert the development or further disability and disorders (DeSocio \& Hootman, 2004). Internalisation problems are especially problematic when it comes to diagnostics since they often go unnoticed. For instance, frequent school absence based on non-specific health problems (somatisations, frequent reporting of aches, pains and medically unexplained medical symptoms) may be related to students' underlying emotional problems (DeSocio \& Hootman, 2004). Early recognition (by school counsellors and classroom teachers) and high quality diagnostic tools (e.g. screening tools) as well as continuous observations are essential. As far as anxiety is concerned in the classroom, some characteristics of anxious students can be of help when trying to identify students with anxiety problems. For instance: (i) anxious students can be worried most of the time; (ii) are usually tense (unable to relax); (iii) will try to avoid school work due to the fear it will not be perfect; (iv) can be extremely well behaved (always following the rules); (v) can become lost in details and therefore not finish school work on time; and (vi) can often look for constant reassurance from their peers or teachers. Regarding depression, longer periods of bad mood, sleepiness, pessimism and signs of learned helplessness should cause educational staff to take a better look.

When addressing anxiety or depression we can use three levels of intervention: universal programmes cover the entire population, selective programmes are geared towards groups with a higher probability of increased anxiety or depression and other problems, and individual programmes are aimed at treating individuals in whom higher levels of anxiety or other problems have been observed (Silverman \& Treffers, 2001). At the school level, universal prevention is the best option as it can cover the largest number of children. Schools are particularly suitable for universal programmes as they encompass the majority of students, without further exposing individuals who are faced with multiple problems (Masten \& Motti-Stefanidi, 2009). These programmes are focused on students who would otherwise not seek professional treatment, even though they would certainly need it. In fact, studies (Mifsud \& Rapee, 2005) have revealed that anxiety, for instance, is commonly overlooked and that students who suffer from such disorders rarely receive professional treatment. 
This is particularly true of students with a low SES (Mifsud \& Rapee, 2005). Another advantage of such programmes is that due to group-based treatment and the fact that the entire group within a class is covered there is no stigmatisation of students who are in need of help. For example, some of the programmes shown to have positive effects on internalising problems are: Coping with Stress Programme, Penn Prevention Programme, Queensland Early Intervention and Prevention of Anxiety Project (see the review in Greenberg, Domitrovich, \& Bumbarger, 2000).

\section{Conclusions}

Mental health problems play a significant role in ESL and often, especially in the case of internalisation problems, go neglected. The need to clearly establish a relationship between mental health (especially anxiety) and ESL is particularly relevant since the research shows that anxiety levels are on the increase in school-aged populations (Kozina, 2014; Twenge, 2000). The underlying mechanisms of mental health problems associated with low achievement are related to lower connectedness to school, negative attitudes to school and peer rejection (in the case of disruptive behaviour disorders), lower engagement through impaired mastery beliefs and negative emotionality (as in the case of depression) and difficulties in cognitive functioning through reduced memory functions and the impact of worries on the cognitive system (as in the case of anxiety). In the prevention and intervention process, school plays a crucial role by early recognition of mental health problems (e.g. withdrawn behaviour, avoidance, perfectionism, somatisations, constant worrying ...) and introducing effective programmes on the universal, selective and individual levels. Schools are well positioned to serve a role in providing accessible, community-sensible mental health services for children. Although most children in need of a mental health service do not receive it, those that do identify school as a primary source of help (DeSocio \& Hootman, 2004).

\section{References}

Anić, N. (2009). Ocena študentov z učnimi težavami [Evaluation of students with learning difficulties]. In N. Anić (Ed.), Prispevki iz vedenjsko kognitivne terapije - zbornik 1 (pp. 257-266). Ljubljana: Društvo za vedenjsko in kognitivno terapijo Slovenije in Svetovalni center za otroke, mladostnike in starše. 
Asarnow, J. R., Jaycox, L. H., Duan, N., LaBorde, A. P., Rea, M. M., Tang, L., ... Wells, \& K. B. (2005). Depression and role impairment among adolescents in primary care clinics. Journal of Adolescent Health, 37, 477-483.

Battin-Pearson, S., Newcomb, M. D., Abbot, R. D., Hill, K. G., Catalano, R. F., \& Hawkins, J.D. (2000). Predictors of early high school drop-out: A test of five theories. Journal of Educational Psychology, 92, 568-582.

Boyce, W., Essex, M., Woodward, H. R., Measelle, J., Ablow, J., \& Kupfer, D. (2002). The confluence of mental, physical, social, and academic difficulties in middle childhood. I: exploring the "headwaters" of early life morbidities. Journal of the American Academy of Child and Adolescent Psychiatry, 41(5), 580-587.

Boxer, P., Edwards-Leeper, L., Goldstein, S. E., Musher-Eizenman, D., \& Dubow, E. F. (2003). Exposure to »low-level« aggression in school: Associations with aggressive behaviour, future expectations, and perceived safety. Violence and Victims, 18(6), 691-704.

Buhs, E. S., Ladd, G. W., \& Herald, S. L. (2006). Peer exclusion and victimization: Processes that mediate the relation between peer group rejection and children's classroom engagement and achievement? Journal of Educational Psychology, 98, 1-13.

Chorpita, B. F. (2002). The tripartite model and dimensions of anxiety and depression: An examination of structure in a large school sample. Journal of Abnormal Child Psychology, 3o(2), 170-199.

DeSocio, J., \& Hootman, J. (2004), Childrens mental health and school success. The Journal of School Nursing, 20(4), 189-196.

Downes, P. (2011). The neglected shadow: European perspectives on emotional supports for early school leaving prevention. The International Journal of Emotional Education, 3(2), 3-36.

Duchesne, S., \& Ratelle, C. (2010). Parental behaviours and adolescents' achievement goals at the beginning of middle school: Emotional problems and potential mediators. Journal of Educational Psychology, 120(2), 497-507.

Eggert, L. L., Thompson, E. A., Randell, B. P., \& Pike, K. C. (2002). Preliminary effects of brief school-based prevention approaches for reducing youth suicide: Risk behaviors, depression, and drug involvement. Journal of Child and Adolescent Psychiatric Nursing, 15(2), 48-64.

Fergusson, D. M., \& Woodworth, L. J. (2002). Mental health, educational and social role outcomes of adolescents with depression. Archives of General Psychiatry, 59, 225-231. 
Flannery, D. J., Vazsonyi, A. T., \& Waldman, I. D. (2007). The Cambridge handbook of violent behaviour and aggression. Cambridge: Cambridge University Press.

Fonseca, A. C. \& Perrin, A. (2001). Clinical phenomenology, classification and assessment of anxiety disorders in children and adolescents. In W. K. Silverman \& P. D. A. Treffers (Eds.), Anxiety disorders in children and adolescents (pp. 126-159). Cambridge: Cambridge University Press.

Fox, J. K., Herzig-Anderson, K., Colognori, D., Stewart, C., \& Masia Warner, C. (2013). School-based treatment of anxiety in children and adolescents: New developments in transportability and dissemination (pp. 355-369). In M. D. Weist, N. A. Lever, C. P. Bradshaw, \& J. S. Owens (Eds.), Handbook of school mental health. New York: Springer.

Hishinuma, E. S., Chang, J. Y., McArdle, J. J., \& Hamagami, F. (2012). Potential causal relationship between depressive symptoms and academic achievement in the Hawaiian high school health survey using contemporary longitudinal latent variable change models. Developmental Psychology, 48, 1327-1342.

Greenberg, M. T., Domitrovich, C. \& Bumbarger, B. (200o). Preventing mental health disorders in school-age children. A review of the effectiveness of Prevention Programs. Rockville: Center for Mental Health Services (CMHS) Substance Abuse Mental Health Services Administration USA Department of Health and Human Services.

Hribar, N. \& Magajna, L. (2011). Prepoznavanje in diagnostično ocenjevanje učencev z učnimi težavami zaradi anksioznosti [Screening and diagnostic evaluation of students with anxiety-based learning difficulties]. In L. Magajna \& M. Velikonja (Eds.), Učenci z učnimi težavami - prepoznavanje in diagnostično ocenjevanje (pp. 1212-1230). Ljubljana: Pedagoška fakulteta Univerze v Ljubljani.

Huesmann, L. R. (1994). Aggressive behaviour - current perspectives. New York and London: Plenum Press.

Ialongo, N., Edelsohn, G., Werthamer-Larsson, L., Crockett, L., \& Kellam, S. (1996). The course of aggression in first-grade children with and without co morbid anxious symptoms. Journal of Abnormal Child Psychology, 24, 445-456.

Kaplan, D. D., Damphousse, J. R., \& Kaplan, H. B. (1994). Mental health implications of not graduating from high school. Journal of Experimental Education, 62, 105-123. 
Kim-Cohen, J., Caspi, A., Moffit, T. E., Harrington, H., Milne, B. J., \& Poulton, R. (2003). Prior juvenile diagnosis in adults with mental disorder: Developmental follow-back of a prospective-longitudinal cohort. Archives of General Psychiatry, 37, 709-717.

Kos, A. (1990). Strah v šoli, strah pred šolo [Fear in school, fear of school]. Ljubljana: Svetovalni center za otroke, mladostnike in starše.

Kozina, A. (2014). Developmental and time-related trends of anxiety from childhood to early adolescence: Two-wave cohort study. The European Journal of Developmental Psychology, 11, 546-559.

Ladd, G. W., Kochenderfer, B. J., \& Coleman, C. C. (1997). Classroom peer acceptance, friendship, and victimization: Distinct relational systems that contribute uniquely to children's school adjustment? Child Development, $68,1181-1197$.

Last, C.G., Hansen, C., \& Franco, N. (1997). Anxious children in adulthood: A prospective study of adjustment. Journal of the American Academy of Child and Adolescent Psychiatry, 36, 645-652.

Masten, A. S., \& Motti-Stefanidi, F. (2009). Understanding and promoting resilience in children: Promotive and protective processes in schools. In $\mathrm{V}$ T. B. Gutkin \& C. R. Reynolds (Eds.), The handbook of school psychology. Hoboken: Wiley.

Mazzone, L., Ducci, F., Scoto, M. C., Passaniti, E., D’Arrigo, V. G., \& Vitiello, B. (2007). The role of anxiety symptoms in school performance in a community sample of children and adolescents. Retrieved from http://www.biomedcentral.com/1471-2458/7/347.

McEvoy, A., \& Welker, R. (200o). Antisocial behaviour, academic failure, and school climate: A critical review. Journal of Emotional and Behavioral Disorders, 8, 130-140.

Mifsud, C., \& Rapee, R. M. (2005). Early intervention for childhood anxiety in a school setting: Outcomes for an economically disadvantaged population. Journal of American Child and Adolescents Psychiatry, 11, 996-1004.

Nelson, J. M., \& Harwood, H. (2011). Learning disabilities and anxiety: A meta-analysis. Journal of Learning Disabilities, 44, 3-17.

Normandeau, S., \& Guay, F. (1998). Preschool behavior and first-grade school achievement: The meditational role of cognitive self-control. Journal of Educational Psychology, 9o, 111-121.

Prevatt, F., Welles, T. L., Li, H., \& Proctor, B. (2010). The contribution of memory and anxiety to the math performance of college students with learning disabilities. Learning Disabilities Research in Practice, 25, 39-47. 
Rinherz, H. Z., Frost, A. K., \& Pakiz, B. (1991). Changing faces: Correlates of depressive symptoms in late adolescence. Family and Community Health, $14,52-63$.

Roderick, M., Arney, M., Axelman, M., DaCosta, K., Steiger, C., Stone, S., Villarreal_Sosa, L., \& Waxman, E. (1997). Habits hard to break: A new look at truancy in Chicago's public high schools. Research brief. Chicago, IL: University of Chicago School of Social Service Administration.

Schwartz, D. J., Hopmeyer Gorman, A., Nakamoto, J., \& Mckay, T. (2006). Popularity, social acceptance, and aggression in adolescent peer groups: Links with academic performance and school attendance. Developmental Psychology, 42, 1116-1127.

Silvermann, W. K., \& Treffers, P. D. A. (2001). Anxiety disorders in children and adolescents. Research, Assessment and Intervention. Cambridge, England: Cambridge University Press.

Vandell, D. L., \& Hembree, S. E. (1994). Peer social status and friendship: Independent contributors to children's social and academic adjustment. Merrill-Palmer Quarterly, 4o(4), 461-477.

Wang, M., \& Peck, S. C. (2013). Adolescent educational success and mental health vary across school engagement profiles. Developmental Psychology, 49, $1266-1276$.

Wentzel, K. R., \& Asher, S. R. (1995). The academic lives of neglected, rejected, popular, and controversial children. Child Development, 66, 754-763.

Woodworth, L. J. \& Fergusson, D. M. (2001). Life course outcomes of young people with anxiety disorders in adolescence. Journal of the American Academy of Child and Adolescent Psychiatry, 40, 1086-1093.

Widoe, R. K., Martins, R. K. \& McNeil, D. W. (2006). Anxiety disorders in ethnic minorities. Encyclopaedia of multicultural psychology. Retrieved from http://sage.reference.com/multiculturalpsychology/article_n24.html

Wienke-Totura, C. M., Mackinnon-Lewis, C., Gesten, E. L., Gadd, R., Divine, K. P., Dunham, S., \& Kamboukos, D. (2009). Bullying and victimization among boys and girls in middle school - the influence of perceived family and school contexts. Journal of Early Adolescence, 29, 571-609.

Twenge, J. M. (2000). The age of anxiety? Birth cohort change in anxiety and neuroticism. Journal of Personality and Social Psychology, 79, 1007-1021.

Quiroga, C. V., Janosz, M., Bisset, S., \& Morin, A. J. S. (2013). Early adolescent depression symptoms and school dropout: Mediating processes involving self-reported academic competence and achievement. Journal of Educational Psychology, 105, 552-560. 
Zhou, Q., Main, A., \& Wang, Y. (2010). The relations of temperamental effortful control and anger/frustration to Chinese children's academic achievement and social adjustment: A longitudinal study. Journal of Educational Psychology, 120, 180-196. 


\subsection{5}

ESL Prevention Extended to the Home Environment: the Relationship Between (Authoritative) Parenting Style and ESL

Tina Rutar Leban

\section{Synopsis}

Research emphasises the positive impact of an authoritative parenting style on school achievements, school engagement and also directly on ESL. Parents' behaviour that is accepting, warm and encouraging yet also firm and with clear expectations has the most favourable impact on a child's/adolescent's development and also acts as an ESL preventive factor. Other parenting styles (authoritarian, permissive and uninvolved) have been examined less.

\section{Summary}

The family has been recognised as one of the primary contributors to children's and adolescents' education (e.g. Baumrind, 1971; Rumberger, 1995; Steinberg, 2001). Different researchers in this field have focused on structural factors such as family background (e.g. SES, parent education etc.) in relation to children's academic achievement and ESL (e.g. McNeal, 1999). Others tried to provide insights into which parenting practices promote school success and prevent ESL (e.g. Alexander, Entwisle, \& Kabbani, 2001; Jimerson et al., 2000 etc.). Some researchers (e.g. Steinberg, 2001; Blondal, 2009; 2014) suggest that, to better understand the influence parents have on their child's/adolescents' education, it is better to look at a conceptualisation of child/adolescent upbringing that characterises parents' actions in a broader perspective, such as the parenting style (i.e. 
authoritative, authoritarian, permissive, and uninvolved, Baumrind (1971)).

Authoritative parents are accepting, warm and encouraging toward their children but at the same time impart clear standards for their children's behaviour, enforcing developmentally appropriate expectations without being intrusive or restrictive (Baumrind, 1971). The authoritative parenting style was shown to impact positively on children's/adolescents' school achievements (e.g. Adalbjarnardottir \& Blondal, 2004; Baumrind, 1991) and school engagement (e.g. SimonsMorton \& Chen, 2009; Steinberg et al., 1994). Research also shows that adolescents from authoritative families are more likely to complete upper secondary education (Blondal \& Adalbjarnardottir, 2009).

A better understanding of the role parenting styles play in ESL prevention might help parents with an improved comprehension of how to motivate and encourage their children's/adolescents' educational aspirations and support their success at school in order to prevent ESL. These insights may also help school professionals who work in multi-partner ESL prevention teams to understand the importance of cooperation with parents in preventing ESL.

Key words: parenting style, early school leaving, parent-child/adolescent relationship, school engagement, school achievement

\section{Introduction}

Home environment/family is one of the important factors which can influence a young person's progression toward school success or failure, staying in school or leaving it before completion (e.g. Brofenbrenner \& Morris, 1998; Jimerson, Egeland, Sroufe, \& Carlson, 200o; Younge, Oetting, \& Deffenbacher, 1996). The family is the earliest and most fundamental socialisation institution for a developing child/adolescent Invalid source specified.. It has also been recognised as a primary contributor to children's/adolescents' education (e.g. Baumrind, 1971; Rumberger, 1995; Steinberg, 2001). Some studies in this field have focused on structural factors such as family background in relation to students' academic achievement and ESL. For example, students from families of higher SES and with higher educated parents are more successful at school and less likely to leave school than students from lower SES families (e.g. McNeal, 1999). 
Other studies have focused on providing insights into what it is in family life that promotes school success and prevents ESL. They have looked into different parenting behaviour, specific practices parents use every day when they interact, educate, socialise their children/adolescents (hereafter referred to as parenting practices e.g. parent involvement in school, parent-child/adolescent communication, caregiving, autonomy support etc.). For example, parental involvement in school was a significant predictor of high school graduation status (Alexander, Entwisle, \& Kabbani, 2001; Ekstrom, 1986; Jimerson, Egeland, Sroufe, \& Carlson, 2000; McNeal, 1999; Rosenthal, 1998; Rumberger, Ghatak, Poulos, Ritter, \& Dornbusch, 1990). Parent-child/adolescent relationship factors such as caregiving quality, parental support (instrumental and emotional), hostility and rejection, and parent-child/adolescent communications were also found to be significant predictors of high school graduation status (Brewster \& Bowen, 2004; Jimerson et al., 2000; McNeal, 1999; Richman, Rosenfeld, \& Bowen, 1998; Rosenthal, 1998; Younge, Oetting, \& Deffenbacher, 1996). In general, the findings from studies that focus on parenting practices relative to adolescents' educational outcomes have been inconsistent and weaker than expected (see the review by Fan \& Chen, 2001). For instance, in some studies parental involvement seems to relate positively to children's/adolescents' achievement (e.g. Hoge, Smit, \& Crist, 1997); other studies indicate no association, or even a negative one. For example, McNeal (1999) found that adolescents whose parents participated in the parent-teacher association received lower grades than their peers.

To better understand the influence parents have on their child's/ adolescent's education, some researchers suggest (e.g. Steinberg, 2001; Blondal \& Adalbjarnardottir, 2009; 2014) it is better to look at a conceptualisation of child/adolescent upbringing that characterises parents' actions in a broader perspective, such as the parenting style (as defined by Baumrind, 1971).

In this article, we focus on the impact of specific parenting practices and parenting styles on ESL and two school-related outcomes (school achievement and school engagement) that have been shown to be important preventive factors for ESL (e.g. Archambault, Janosz, Fallu, \& Pagani, 2009; Ensminger, Lamkin, \& Jacobson, 1996; Finn, 1989; Simpkins, Fredericks, \& Eccles, 2015) (see Figure 14). 


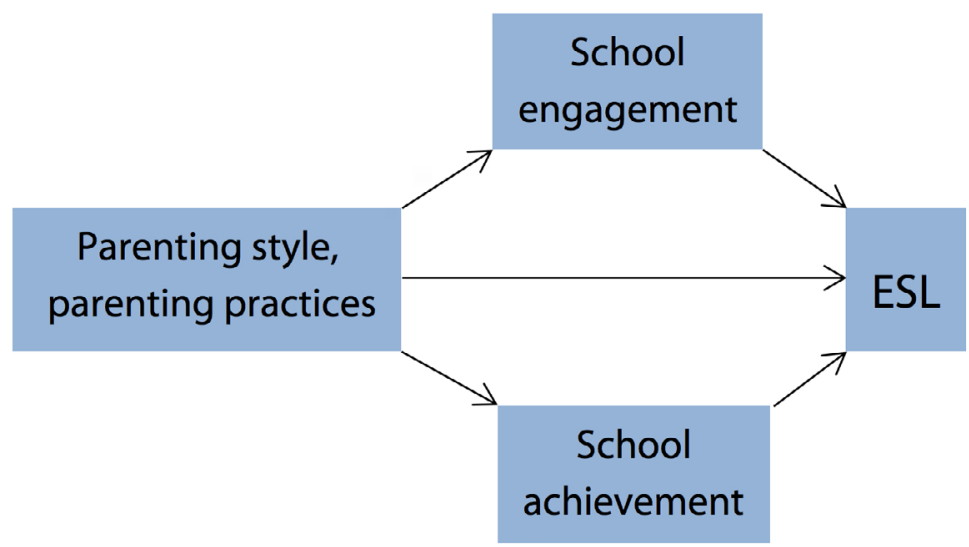

Figure I4. Conceptual framework of the relationship between parenting style/practice and education related outcomes (achievement, engagement, ESL)

A better understanding of the role of parenting style in preventing ESL might help parents better understand how to motivate and encourage their children's/adolescents' educational aspirations and support their success at school in order to stop ESL. It may also help school professionals who work in multi-partner ESL prevention teams to understand the importance of cooperation with parents in ESL prevention and all other school professionals to develop ESL prevention programmes for parents. The relationship between parenting style and ESL also informs policy-makers about the importance of systematic cooperation between school and parents.

\section{Methodology}

The article is based on a review of the literature that involved searching in the PsycINFO, ERIC, Proquest, Science Direct and Google scholar search databases. Key words used in the literature search were family factors for early school leaving, parenting styles, home environment, school performance, school achievements, parental beliefs, parental behaviours, school dropout, predictors for early school leaving etc. For the purposes of this article, we chiefly considered scientific papers, some online scientific books and study reports. 


\section{Parenting styles}

Contemporary research on parenting styles derives from Baumrind's (1971, 1978) studies of family interactions. Baumrind (1973) defined parenting style as a consistent pattern with which parents interact with their children along two dimensions: demandingness and responsiveness. Demandingness refers to parental efforts to integrate children into the family through maturity demands, supervision, discipline, and willingness to confront behavioural problems. Responsiveness refers to the extent to which parents foster individuality, self-regulation and self-assertion by consenting to or being aware and supportive of children's needs and demands (Baumrind, 1991). Based on these two dimensions, Baumrind classified four parenting styles: authoritarian (high demandingness, low responsiveness), authoritative (high demandingness, high responsiveness), permissive (low demandingness, high responsiveness), and uninvolved parenting style (low demandingness and low responsiveness). Authoritarian parents are demanding and controlling, but not responsive or warm. They have clear rules that their children are not supposed to question. Authoritative parents are accepting, warm and encouraging toward their children yet at the same time firm; they impart clear standards for their children's behaviour, enforcing developmentally appropriate expectations without being intrusive or restrictive. Permissive parents on the other hand are responsive and warm. They allow considerable self-regulation, but are lenient and avoid confrontation. Uninvolved parents are neither responsive nor demanding. They do not monitor or guide their children/adolescents and do not support them or relate to them with warmth.

This typology of parenting style provides an opportunity to explore relationships among the multidimensional characteristics of parenting and the adjustment of youth (Adalbjarnardottir \& Hafsteinsson, 2001; Lambom et al., 1991; Steinberg et al., 1994; Türkei \& Tezer, 2008). Results of various studies show that an authoritative parenting style is, generally speaking, most suitable for raising children/adolescents in western, technologically and educationally advanced countries (e.g. Baumrind, 1967, 1971, 1989; Darling \& Steinberg, 1993; Denham, Renwick, \& Holt, 1991; Kuczyinski \& Kochanska, 1995; Maccoby \& Martin, 1983; Steinberg, 2001). Authoritative parents are accepting, warm and encouraging towards their children/adolescents. At the same time, they supervise their children's/adolescents behaviour, impart clear standards and enforce developmentally appropriate expectations without being intrusive or restrictive. During adolescence, 
they apply democratic discipline and encourage their adolescents to express their thoughts and feelings. They also support their adolescents' needs for more independence. Gray and Steinberg (1999) examined the core dimensions of authoritative parenting - autonomy granting, acceptance, and supervision - and found that all three related to adolescents' academic competence. Compared to their peers raised in non-authoritative family settings, children and adolescents from authoritative families have been shown to obtain higher scores on a wide variety of measures of adjustment, psychosocial development, and academic achievement (e.g. Adalbjarnardottir \& Hafsteinsson, 2001; Baumrind, 1991; Gray \& Steinberg, 1999; Steinberg et al., 1994; Türkel \& Tezer, 2008).

\section{Impact of parenting style and practices on children's/ adolescents' school achievement}

Students who show low academic achievements have consistently been shown to be at a higher risk for ESL than other students. Academic achievement is one of the strongest predictors of ESL (e.g. Battin-Pearson, Newcomb, Abbott, Hill, Catalano, \& Hawkins, 20oo; Jonasson \& Blondal, 2002; Rumberger, 1995). Moreover, it may mediate the relationship between parenting style and ESL as adolescents' achievement varies by parenting style (Adalbjarnardottir \& Blondal, 2004). Therefore, parenting style may influence the likelihood of ESL partly due to its influence on adolescents' academic achievement (see Figure 14).

Studies show that adolescents who perceive their parents as authoritative are more likely to earn higher grades at school than adolescents who perceive their parents as non-authoritative (e.g. Adalbjarnardottir \& Blondal, 2004; Baumrind, 1991). Positive associations between parent involvement and academic achievement have been demonstrated in different studies. A meta-analysis (Fan \& Chen, 2001) indicated moderate associations between parent involvement and an array of learning-related or academic skills, such as achievement motivation, task persistence and receptive vocabulary. In his study, Yaffe (2015) examined the relationship between parenting style, parental involvement in school and achievement among students with disabilities. The results of the study indicated that parenting style and parental involvement in school explain a significant proportion of the variance in educational functioning among students included in the study. Parenting style and parental involvement modestly predicted academic achievements in language skills and mathematics. The 
significant relationships between parenting style and educational functioning and achievements pointed to the better performance of students with authoritative parents compared to students with authoritarian ones.

Several variations of social cognitive models of parental influence were proposed, focusing on children's/adolescents' academic achievement-related behaviours and outcomes (e.g. Eccles-Parsons, Adler, \& Kczala, 1982; Goodnow \& Collins, 1990; Grolnick \& Slowiaczek, 1994; Holloway, 1988; Marjoribanks, 2002). Eccles and her colleagues developed a model in which they elaborated diverse pathways through which parents might influence their children's achievement-related choices and motivational beliefs (Eccles, Arberton, Buchanan, Janis, Flanagan, Harold, \& Reuman, 1993). They proposed that parents can shape children's/adolescents' motivational beliefs (e.g. self-concept of ability, task value) and achievement-related choices (including ESL) through a variety of child-/adolescent-specific beliefs (for instance, expectations of a child's/adolescent's achievement, perceptions of a child's/adolescent's abilities, perception of the values of various skills for the child/adolescent, perceptions of child's/adolescent's interests, and specific socialisation goals) and behaviours (such as teaching strategies, career guidance, encouragement of various activities, provision of tools, toys opportunities, causal attributions for a child's behaviour and outcomes, and emotional tone in interactions). The model was tested in a longitudinal study lasting over a period of 12 years involving children/ adolescents and their parents (Frome \& Eccles, 1998; Fredricks \& Eccles, 2002; Simpkins, Fredericks, \& Eccles, 2015). The results showed support for the hypothesis that parents influence children's/adolescents' motivation for school performance and that parents' beliefs about their children's/adolescents' abilities and competencies are quite stable Invalid source specified.. The findings also suggest that targeting parents prior to elementary school (when children are still developing their achievement-related motivation) will be a more effective method for increasing children's long-term school motivation than targeting parents later in the elementary school years or even high school years when ESL is already present as a problem. These interventions can educate parents about how they can shape children's beliefs about school by providing inputs about their emerging abilities and the value of different skills. The results also demonstrate the important role early motivational beliefs (e.g. self-concept of ability, task value) play in shaping achievement-related choices in high school. 


\section{Impact of parenting style on children's/adolescents' school engagement}

School engagement is an important concept in most ESL theories (e.g. Finn, 1989; Newman, Wehlage, \& Lambdorn, 1992; Rumberger \& Larsson, 1998). Studies show that it is also related to academic achievement (Alexander, Entwisle, \& Horsey, 1997; Finn, 1993; Finn \& Rock, 1997; Rumberger, 1995).

Different studies indicate the importance of the proximal environment in fostering school engagement (Fredricks, Blumenfeld, \& Paris, 2004; Van Ryzin, Gravely, \& Roseth, 2009). For example, Wang and Eccles (2012) found that social support from parents, teachers and peers facilitates adolescents' school engagement. Results of the same study also showed that parental lack of social support (in comparison to peer lack of social support) was more important in reducing adolescents' school engagement. Fewer studies have examined the importance of a multidimensional parenting style - a broader conceptualisation of child/adolescent upbringing in comparison to single-parent practice - to foster school engagement among adolescents (Simons-Morton \& Chen, 2009). Findings from these studies indicate that authoritative parenting is positively associated with student school engagement (Simons-Morton \& Chen, 2009; Steinberg et al., 1994). A recent study by Blondal and Adalbjarnardottir (2014) revealed that adolescents with more authoritative parents (high acceptance, supervision, and psychological autonomy granting) were more likely to finish school compared to adolescents with less authoritative parents. The level of school engagement partly mediated the relationship between authoritative parenting and school completion. These results stress the impact of parenting style on adolescents' school engagement, which in turn reduces the risk of ESL (see Figure 14) (Blondal \& Adalbjarnardottir, 2014).

\section{Impact of parenting style and parenting practices on ESL}

Studies researching the influence of parenting on children's and adolescents' school outcomes have mostly focused on specific parental practices such as parental involvement in a child's education (McNeal, 1999; Rumberger, 1995) or parental support (Alexander, Entwisle, \& Kabbani (2001). Parental involvement in school activities and contacts with teachers may help to identify a child's struggles and intervene earlier to minimise the damage of a possible negative experience for the child (Chavkin \& Williams, 1993).The extent to which parents are involved in their child's 
schooling impacts their child's perceptions about school and its importance (Chavkin \& Williams, 1993). Oyserman, Brickman and Rhodes (2007) highlighted that parental involvement in school impacts children's/adolescents' belief that school is either important or unimportant, depending on the level of parental involvement provided. Studies have also shown that parental involvement in children's homework is important for developing positive attitudes and study skills, which are essential for school success (Hoover-Dempsey, Battiato, Walker, Reed, DeJong, \& Jones, 2001). McNeal (1999) referred to four types of parenting involvement (types of parenting social capital) that are associated with children's/adolescents' educational outcomes, including ESL: parent-child/adolescent discussion related to education, parental involvement in the parent-teacher organisation, parental monitoring of children's/adolescents' behaviour, and direct parental involvement in children's/adolescents' educational practices. Of these four types of parental involvement, McNeal found the extent to which parents and children/adolescents regularly discuss education issues (parent-child/ adolescent discussion) had the greatest impact on educational outcomes. Parental support helps direct children/adolescents towards positive behaviour in school by reinforcing the notion of education as valuable and by monitoring children's/adolescents' engagement in school (McNeal, 1999; Pong, 1997).

Jimerson, Egeland, Sroufe and Carlson (2000) explored multiple predictors of high school ESL across adolescent development (a 19-year prospective longitudinal study). Their proposed model of ESL emphasises the importance of the early home environment and the quality of early caregiving influencing subsequent development. The results of this study indicate an important association of the early home environment, the quality of early caregiving, SES, IQ, behavioural problems, academic achievement, peer relations, and parent involvement with high school ESL at age 19. Correlations between maternal rejection and ESL were also found (Younge, Oetting, \& Deffenbacher, 1996). Rejection and hostility scores of mothers whose sons had left school prior to completion and of mothers whose sons were doing well academically formed non-overlapping distributions. All mothers of ESLers had higher hostility and rejection scores than mothers whose sons were doing well academically. The scores of mothers whose sons were still in school, but were experiencing academic problems, fell midway between these two groups and were significantly different from both (Younge, Oetting, \& Deffenbacher, 1996). 
The relationship between a broader conceptualisation of parenting practices (such as the parenting style) and ESL has not often been studied, although some studies have found a direct link between parenting style and school completion (see Figure 14). One of the cross-sectional studies in this field was conducted by Rumberger, Ghatak, Poulos, Ritter and Dornbusch (1990). The study was based on Baumrind's $(1971,1991)$ parenting style typology and provides evidence that adolescents with authoritative parents are less likely to leave school prematurely compared to adolescents raised by permissive parents. Another longitudinal study (Blondal \& Adalbjarnardottir, 2009) indicates that 14-year-olds from authoritative families are more likely to have completed upper secondary education by age 22 compared to adolescents from non-authoritative families (when controlling for gender, SES, temperament, and parental involvement).

\section{Conclusions and implications for practice}

The evidence presented in this article shows that specific parenting practices and also a broader concept of parental dimensions defined as parenting styles have an important impact on ESL and its prevention (e.g. Archambault, Janosz, Fallu, \& Pagani, 2009; Ensminger, Lamkin, \& Jacobson, 1996; Finn, 1989; Simpkins, Fredericks, \& Eccles, 2015). For example, parent-child/adolescent relationship factors such as caregiving quality, parental support (instrumental and emotional), hostility and rejection, and parent-child/adolescent communications all predict ESL or, on the other hand, high school completion (e.g. Brewster \& Bowen, 2004; Jimerson et al., 2000). In a broader conceptualisation of a child's upbringing, such as the parenting style (as defined by Baumrind (1971)), authoritative parenting style (parents' accepting, warm and encouraging yet firm behaviour towards their children/adolescents, with clear standards and expectations for their behaviour) has the most favourable impact on their development and also acts as an ESL preventive factor (e.g. Steinberg, 2001).

In the light of the presented findings and conclusions, it would be advisable to present these findings to parents, different profiles of school workers and multi-partner teams that focus in their work on preventing ESL and other school-related problems. Moreover, it might also be useful to present these findings to teachers since some researchers have compared teaching styles to parenting styles. They found that teachers' characteristics similar to those parenting practices characterised as authoritative (warm and autonomy-supportive as opposed to controlling) were found to be positively 
related to student motivation, feelings of academic competence (e.g. Moos, 1978; Ryan, Stiller, \& Lynch, 1994; Wentzel, 1997) and engagement (Fallu \& Janosz, 2003; Crosnoe, Kirkpatrick, Johnson \& Elder, 2004; Murray \& Malgrem, 2005). Schools could, for example, develop various education and training courses where parents and teachers could be familiarised with practical ways of fostering an authoritative parenting/teaching style. Such parent/teacher training would help parents and teachers understand that by granting adolescents a greater degree of autonomy and responsibility they can support their academic achievements, their perception of self-efficacy and help them be more engaged in school and less inclined to leave school. Another idea would be to highlight the contents related to autonomy in children/adolescent upbringing as part of teachers' initial educational programmes, thus contributing to the dissemination of study findings in the school sphere.

Different evaluations of ESL prevention programmes have shown (see Hall, 2014) the most successful strategy of ESL prevention engaged in by parent(s). Programmes with parental involvement, family counselling and conflict resolution components often achieved greater success than those without parental involvement (White, 2010). Students demonstrated increased attendance, improved academic motivation as well as improved performance and behaviour when their parents were also involved in ESL prevention programmes (Cheney, Stage, Hawken, Lynass, Mielenz, \& Waugh, 2009). Moreover, parents could also be (more actively) included in the multi-partner cooperation with school professionals in teams working on the subject of preventing ESL. In this way, parents would be able to contribute their insights into the subject and also simultaneously learn from the professionals and establish a bridge between research and practice in the field of parenting.

\section{References}

Adalbjarnardottir, S., \& Hafsteinsson, L. G. (2001). Adolescents' perceived parenting styles and their substance use: Concurrent and longitudinal analyses. Journal of Research on Adolescence, 11(4), 401-423.

Adalbjarnardottir, S., \& Blondal, K. S. (2004). Uppeldish ættir foreldra og n á $\mathrm{m}$ - $\mathrm{s}$ árangur unglinga á samræmdum pr ófum við lok grunnsk óla [Parenting styles and adolescents' academic achievement in standardised national tests]. In U. Hauksson (Ed.), Ranns óknir í félagsvísindum 
V (Research of Social Sciences V) (pp. 415-426). Reykjavík: Social Science Research Institute and the University Press.

Alexander, K. L., Entwisle, D. R., \& Kabbani, N. (2001). The dropout process in life course perspective: Early risk factors at home and school. Teachers College Record, 103(5), 760-822.

Archambault, I., Janosz, M., Fallu, J. S., \& Pagani, L. S. (2009). Student engagement and its relationship with early high school dropout. Journal of Adolescence, 32(3), 651-670.

Battin-Pearson, S., Newcomb, M. D., Abbott, R. D., Hill, K. G., Catalano, R. F., \& Hawkins, J. D. (2000). Predictors of early high school dropout: A test of five theories. Journal of Educational Psychology, 92(3), 568-582.

Baumrind, D. (1967). Child care practices anteceding three patterns of preschool behavior. Genetic Psychology Monographs, 75(1), 43-88.

Baumrind, D. (1971). Current patterns of parental authority. Developmental Psychology, 4(1p2), 1-103.

Baumrind, D. (1973). The development of instrumental competence through socialization. Minnesota Symposium on Child Psychology, Vol. 7 (3-46).

Baumrind, D. (1978). Parental disciplinary patterns and social competence in children. Youth and Society, 9(3), 239-276.

Baumrind, D. (1989). The permanence of change and the impermanence of stability. Human Development, 32(3-4), 187-195.

Baumrind, D. (1991). The influence of parenting style on adolescent competence and substance use. The Journal of Early Adolescence, 11(1), 56-95.

Blondal, K. S., \& Adalbjarnardottir, S. (2009). Parenting practices and school dropout: A longitudinal study. Adolescence, 44(176), 729-749.

Blondal, K. S., \& Adalbjarnardottir, S. (2014). Parenting in relation to school dropout through student engagement: A longitudinal study. Journal of Marriage and Family, 76(4), 778-795.

Brewster, A. B., \& Bowen, G. L. (2004). Teacher support and the school engagement of Latino middle and high school students at risk of school failure. Child and Adolescent Social Work Journal, 21(1), 47-67.

Bronfenbrenner, Urie, \& Morris, Pamela A. (1998). The ecology of developmental processes. In W. Damon \& R. M. Lerner (Eds.). Handbook of child psychology: Theoretical models of human development, Volume 1, 5 th ed. (pp. 993-1028). Hoboken, NJ, USA: John Wiley \& Sons Inc.

Chavkin, N. F., \& Williams, D. L. (1993). Minority parents and the elementary school: Attitudes and practices. In Chavkin, N. F. (Ed.), Families and 
schools in a pluralistic society (pp. 73-83). New York: State University of New York Press.

Cheney, D. A., Stage, S. A., Hawken, L. S., Lynass, L., Mielenz, C., \& Waugh, M. (2009). A 2-year outcome study of the check, connect, and expect intervention for students at risk for severe behavior problems. Journal of Emotional and Behavioral Disorders, 17(4), 226-243.

Crosnoe, R., Johnson, M. K., \& Elder, G. H. (2004). Intergenerational bonding in school: The behavioral and contextual correlates of student-teacher relationships. Sociology of Education, $77(1), 60-81$.

Darling, N., \& Steinberg, L. (1993). Parenting style as context: An integrative model. Psychological Bulletin, 113(3), 487-496.

Denham, S. A., Renwick, S. M., \& Holt, R. W. (1991). Working and playing together: Prediction of preschool social-emotional competence from mother-child interaction. Child Development, 62(2), 242-249.

Eccles, J. S., Arberton, A., Buchanan, C. M., Janis, J., Flanagan, C., Harold, R., ... Reuman, D. (1993). School and family effects on the ontogeny of children's interests, self-perceptions, and activity choices. Nebraska Symposium on Motivation (Vol. 40, pp. 145-208). Lincoln, NE: U. Nebraska Press.

Eccles-Parsons, J., Adler, T. F., \& Kaczala, C. M. (1982). Socialization of achievement attitudes and beliefs: Parental influences. Child Development, 53(2), $310-321$.

Ekstrom, R. B. (1986). Who drops out of high school and why? Findings from a national study. Teachers College Record, 87(3), 356-73.

Ensminger, M. E., Lamkin, R. P., \& Jacobson, N. (1996). School leaving: A longitudinal perspective including neighborhood effects. Child Development, $67(5), 2400-2416$.

Ensminger, M. E., \& Slusarcick, A. L. (1992). Paths to high school graduation or dropout: A longitudinal study of a first-grade cohort. Sociology of Education, 95-113.

Fan, X., \& Chen, M. (2001). Parental involvement and students' academic achievement: A meta-analysis. Educational Psychology Review, 13(1), 1-22.

Fallu, J. S., \& Janosz, M. (2003). La qualité des relations élève-enseignants à l'adolescence: Un facteur de protection de l'échec scolaire. Revue de psychoéducation et d'orientation, 32(1), 7-29.

Finn, J. D. (1989). Withdrawing from school. Review of Educational Research, $59(2), 117-142$. 
Finn, J. D., \& Rock, D. A. (1997). Academic success among students at risk for school failure. Journal of Applied Psychology, 82(2), 221-234.

Fredricks, J. A., Blumenfeld, P. C., \& Paris, A. H. (2004). School engagement: Potential of the concept, state of the evidence. Review of Educational Research, 74(1), 59-109.

Fredricks, J. A., \& Eccles, J. S. (2002). Children's competence and value beliefs from childhood through adolescence: growth trajectories in two malesex-typed domains. Developmental Psychology, 38(4), 519-533.

Frome, P. M., \& Eccles, J. S. (1998). Parents' influence on children's achievement-related perceptions. Journal of Personality and Social Psychology, 74(2), 435-452.

Gray, M. R., \& Steinberg, L. (1999). Unpacking authoritative parenting: Reassessing a multidimensional construct. Journal of Marriage and the Family, 61, 574-587.

Goodnow, J. J., \& Collins, W. A. (1990). Development according to parents: The nature, sources, and consequences of parents' ideas. New York: Psychology Press.

Grolnick, W. S., \& Slowiaczek, M. L. (1994). Parents' involvement in children's schooling: A multidimensional conceptualization and motivational model. Child Development, 65(1), 237-252.

Hall, R. A. (2014). Challenges on the road to school success for low socio-economic and minority students school dropout and parent involvement (Doctoral dissertation, Lynn University).

Hoge, D. R., Smit, E. K., \& Crist, J. T. (1997). Four family process factors predicting academic achievement in sixth and seventh grade. Educational Research Quarterly, 21(2), 27-42.

Holloway, S. D. (1988). Concepts of ability and effort in Japan and the United States. Review of Educational Research, 58(3), 327-345.

Hoover-Dempsey, K. V., Battiato, A. C., Walker, J. M., Reed, R. P., DeJong, J. M., \& Jones, K. P. (2001). Parental involvement in homework. Educational Psychologist, 36(3), 195-209.

Jimerson, S., Egeland, B., Sroufe, L. A., \& Carlson, B. (200o). A prospective longitudinal study of high school dropouts examining multiple predictors across development. Journal of School Psychology, 38(6), 525-549.

Jónasson. J. T., \& Blondal. K. S. (2002). Námsferill. námslok og búseta. Rannsókn á námsferli '75 árgangsins. [Student progress. Graduation and residence. 
Study of the 1975 cohort.] Reykjavík: Social Science Research Institute. University of Iceland.

Kuczynski, L., \& Kochanska, G. (1995). Function and content of maternal demands: Developmental significance of early demands for competent action. Child Development, 66, 616-628.

Lamborn, S. D., Mounts, N. S., Steinberg, L., \& Dornbusch, S. M. (1991). Patterns of competence and adjustment among adolescents from authoritative, authoritarian, indulgent, and neglectful families. Child Development, 62(5), 1049-1065.

Marjoribanks, K. (2002). Family and school capital: Towards a context theory of students' school outcomes. Dordrecht: Springer Science \& Business Media.

Maccoby, E. E., \& Martin, J. A. (1983). Socialization in the context of the family: Parent-child interaction. Handbook of child psychology: formerly Carmichael's Manual of child psychology/Paul H. Mussen, editor.

McNeal, R. B. (1999). Parental involvement as social capital: Differential effectiveness on science achievement, truancy, and dropping out. Social Forces, 78(1), 117-144.

Moos, R. (1978). A typology of junior high and high school classrooms. American Educational Research Journal, 15, 53-66.

Murray, C., \& Malmgren, K. (2005). Implementing a teacher-student relationship program in a high-poverty urban school: Effects on social, emotional, and academic adjustment and lessons learned. Journal of School Psychology, 43(2), 137-152.

Newcomb, M. D. (1997). General deviance and psychological distress: Impact of family support/bonding over 12 years from adolescence to adulthood. Criminal Behaviour and Mental Health, 7(4), 369-40o.

Newmann. F., Wehlage. G. G., \& Lamborn. S. D. (1992). The significance and sources of student engagement. In F. Newmann (Ed.). Student engagement and achievement in American secondary schools (pp. 11-39). New York: Teachers College Press.

Oyserman, D., Brickman, D., \& Rhodes, M. (2007). School success, possible selves, and parent school involvement. Family Relations, 56(5), 479-489.

Pong, S. L. (1997). Family structure, school context, and eighth-grade math and reading achievement. Journal of Marriage and the Family, 59, 734-746.

Richman, J. M., Rosenfeld, L. B., \& Bowen, G. L. (1998). Social support for adolescents at risk of school failure. Social Work, 43(4), 309-323. 
Rosenthal, B. S. (1998). Non-school correlates of dropout: An integrative review of the literature. Children and Youth Services Review, 2o(5), 413-433.

Rumberger, R. W. (1995). Dropping out of middle school: A multilevel analysis of students and schools. American Educational Research Journal, 32(3), $583-625$.

Rumberger, R. W., \& Larson, K. A. (1998). Student mobility and the increased risk of high school dropout. American Journal of Education, 107, 1-35.

Rumberger, R. W., Ghatak, R., Poulos, G., Ritter, P. L., \& Dornbusch, S. M. (1990). Family influences on dropout behavior in one California high school. Sociology of Education, 63, 283-299.

Ryan, R. M., Stiller, J. D., \& Lynch, J. H. (1994). Representations of relationships to teachers, parents, and friends as predictors of academic motivation and self-esteem. Journal of Early Adolescence, 14, 226-249.

Simons-Morton, B., \& Chen, R. (2009). Peer and parent influences on school engagement among early adolescents. Youth \& Society, 41(1), 3-25.

Simpkins, S. D., Fredricks, J. A. \& Eccles, J. S. (2015). The role of parents in the ontogeny of achievement-related motivation and behavioral choices. Monographs of the Society for Research in Child Development, 8o(2), 1-169.

Steinberg, L. (2001). We know some things: Parent-adolescent relationships in retrospect and prospect. Journal of Research on Adolescence, 11(1), 1-19.

Steinberg, L., Lamborn, S. D., Darling, N., Mounts, N. S., \& Dornbusch, S. M. (1994). Over-time changes in adjustment and competence among adolescents from authoritative, authoritarian, indulgent, and neglectful families. Child Development, 65(3), 754-770.

Türkel, Y. D., \& Tezer, E. (2008). Parenting styles and learned resourcefulness of Turkish adolescents. Adolescence, 43(169), 143-152.

Van Ryzin, M. J., Gravely, A. A., \& Roseth, C. J. (2009). Autonomy, belongingness, and engagement in school as contributors to adolescent psychological well-being. Journal of Youth and Adolescence, 38(1), 1-12.

Wang, M. T., \& Eccles, J. S. (2012). Social support matters: Longitudinal effects of social support on three dimensions of school engagement from middle to high school. Child Development, 83(3), 877-895.

Wentzel, K. R. (1997). Student motivation in middle school: The role of perceived pedagogical caring. Journal of Educational Psychology, 86, 173-182.

White, S. W., \& Kelly, F. D. (2010). The school counselor's role in school dropout prevention. Journal of Counseling and Development: JCD, 88(2), 227. 
Yaffe, Y. (2015). Parenting styles, parental involvement in school, and educational functioning of children with special needs integrated into mainstream education. Journal of Studies in Education, 5(4), 258-277.

Younge, S. L., Oetting, E. R., \& Deffenbacher, J. L. (1996). Correlations among maternal rejection, dropping out of school, and drug use in adolescents: A pilot study. Journal of Clinical Psychology, 52(1), 96-102. 



\subsection{6 \\ Learning Difficulties and ESL \\ Tina Vršnik Perše}

\section{Synopsis}

Students with learning difficulties are at a greater risk for ESL than their peers since they are disproportionately more likely to experience other risk factors for ESL at the individual, family, school, community and/or system levels. Multiple and individualised approaches should be used by the system and educators to reduce the influence of these factors.

\section{Summary}

All across Europe, young people who leave school early are more likely to come from disadvantaged groups. These include young people with a disability, special needs or physical and mental health problems (NESSE, 2010). Students with learning difficulties are considered one of the disadvantaged groups even though there is no single interpretation or agreed definition of the term 'learning difficulty'. To better understand the background of learning difficulties and its relationship with ESL, a basic overview of the terminology is introduced in the paper. Regardless of the particular definition, students with learning difficulties are affected by several factors that influence their tendency for ESL even more than their peers, such as personal attitudes, family and community, and especially the teachers, the education system and also others. Students with learning difficulties indicate they do not feel engaged and connected to the 
school since the traditional programmes and teachers fail to meet their needs (Palladino, Poli, Masi, \& Marcheschi, 2000).

Interventions to combat ESL therefore need to be based on an understanding of its complex determinants and the factors that operate in individual cases. The goal should be to promote a wholeschool approach including teachers' professional development since teachers' improved social and emotional competencies and didactical approaches would offer a great supportive factor for students with learning difficulties in the ESL prevention context.

Some programmes have already proven to be successful for preventing ESL for students with learning difficulties, such as Cognitive Behavioural Interventions, the Check and Connect programme, and Shema Broadening Instruction. Therefore, further development of prevention programmes could be based on experiences with them.

Key words: learning difficulties, learning disabilities, early school leaving, prevention

\section{Introduction}

Learning difficulties have constituted very diverse and extensive phenomena in education research ever since reading and maths literacy were recognised as key skills for mastering everyday life with education institutions being considered responsible for developing those skills and others. In the present century, the extent and problem of educating students with learning difficulties is more and more recognised although it is impossible to exactly determine the extent of the phenomenon since there is no consensus on the definition and diagnosis of learning difficulties. Even the terminology is not abundantly clear since learning difficulties, learning disabilities and learning disorders are often used as synonyms. In addition, the term special educational needs includes similar descriptions.

Depending on various definitions, some authors (Geary, 2006; Mercer \& Pullen, 2005) claim that there is a $4 \%-8 \%$ prevalence of learning difficulties among students. Other authors indicate quite different proportions of students with learning difficulties or learning disabilities. Taanila, Yliherva, Kaakinen, Moilanen \& Ebeling (2011) reported that in Finland approximately $21 \%$ of children had learning difficulties. As explained, the terminology is a great issue while attempting to determine the precise prevalence of students with learning difficulties. 
The complexity of the phenomena is even more evident when the relationship between learning difficulties and ESL is being established. Nevertheless, it is evident that the prevalence of ESLers among students with learning difficulties is much bigger than the prevalence among their peers (Wagner, 1991). It is therefore necessary to understand the features of the phenomena in detail in order to develop efficient interventions.

Thus, the aim of this article is to outline the terminology of learning difficulties/disorders/disabilities and to explain the relationship with ESL as well as possible implications and approaches for teachers and other educators working with students with learning difficulties.

\section{Methodology}

We conducted a review of the literature by searching in the ERIC (EBSCOhost), SpringerLink, Wiley, Sage, Proquest, and Science Direct search engines for information about learning difficulties, learning disabilities and their relationship with ESL. We included three types of documents in the search: scientific papers, scientific monographs explaining the theoretical background, along with EU documents and reports on the subject matter.

The research on learning difficulties and learning disabilities is a highly targeted issue since, for example, the EBSCOhost Information Services reports about 6,00o papers and books on learning difficulties and more than 30,000 academic papers and books on learning disabilities. However, relatively few papers examine the direct relationship between learning difficulties/disabilities and ESL. Therefore, several papers were considered that explain the relationship between ESL and different factors related to ESL. Only a few included learning difficulties as an explanatory factor for ESL although several papers indicate that the proportion of students with learning difficulties among ESLers is much greater than the proportion among their peers.

\section{Defining learning difficulties}

In both the research and literature many different terms are used to describe special educational needs specifically related to learning. Since the definitions and terminology vary widely, it is necessary to first introduce the relationship between the definitions and terms in order to allow us to subsequently indicate the relationship with ESL. 
The Oxford English Dictionary (b.d.) defines learning difficulties as difficulties in acquiring knowledge and skills at the normal level expected of those of the same age, especially due to mental disability or cognitive disorder covering the range from Down's syndrome to conditions such as dyslexia. It also (ibid.) defines a learning disability as a condition giving rise to learning difficulties, especially when not associated with a physical disability.

Although the Oxford English Dictionary is one of the most referred to dictionaries, its definition is not explicit enough to be adopted by different authors and countries. In country-specific contexts, several definitions have been adopted.

In English-speaking countries, different terms especially "learning disability", "learning difficulty" as well as "learning dysfunction", "learning disorder", "learning deficit" and "learning delay" are used (Taanila et al., 2011) and the meanings are not monolithic. The definition of students with learning disabilities or students with learning difficulties varies in different countries, underlining the complexity of the issue.

In the United Kingdom (UK), the terms "learning difficulty" and "learning disability" are often used interchangeably, which is confusing. The Children and Families Act (2014) states that a child or young person has special educational needs if they have a learning difficulty or disability which calls for special educational provision to be made for him or her. A child or young person has a learning difficulty or disability if they:

- have significantly greater difficulty in learning than the majority of others of the same age; or

- have a disability which prevents or hinders them from making use of facilities of a kind generally provided for others of the same age in mainstream schools or mainstream post-16 institutions.

The Equality Act (2010) defines disability as a physical or mental impairment that has a "substantial" and "long-term" negative effect on one's ability to perform normal daily activities. It explains that, unlike learning disability, a learning difficulty does not affect general intelligence but is described as specific problems in processing certain forms of information. While this was one attempt to distinguish "difficulties" from "disabilities", in the UK today the understanding that "learning difficulties" also include a general impairment of intelligence is still present. 
In the USA, the term "learning disability" has a different meaning. Learning disability is used there to cover several specific learning disorders particularly in relation to reading, writing and maths, such as dyslexia, dyspraxia and dyscalculia. The terms "intellectual disabilities" and "mental retardation" are commonly used as labels to describe what in the UK would be understood as learning disabilities (Hardie \& Tilly, 2012).

In France, Law no. 2005-102 of 11 February 2005 (Art. L. 114 of the Social Action and Families Code) defines disability in the following manner: "What constitutes a disability, in the present law's meaning, is any limitation of a person's activity or limitation of participation in social life in their environment because of a substantial, lasting or definitive alteration of one or several physical, sensory, mental, cognitive or psychological functions, a multi-disability or debilitating health problem" (Eurydice, n.d.). Regarding the definitions presented above, this is a much broader description since it includes the entire scope of impairments and is considered in such a way that includes all different special (educational) needs.

In Germany, predominantly the term "learning disabilities" is described. Despite the literal translation of the term "learning disabilities" and the significant historical German-European contributions to the American concept of learning disabilities, Lernbehinderung has little in common with the American concept of learning disability. In describing the German school population with Lernbehinderung, four special education populations are emerging: (a) students having school achievement problems with different causes, including poor teaching; (b) deficits in cognitive functions (low IQ); (c) specific learning disabilities (perception-processing disorders); and (d) sociocultural or socioeconomic deprivation (Opp, 1992). Also in the German context, Büttner and Hasselhorn (2011) state that students with difficulties in specific cognitive processes and academic achievement with otherwise normal levels of intellectual functioning are classified as having a learning disability. This indicates that more contemporary definitions at least partly exclude the above-mentioned deficits in cognitive functions.

Regarding the definitions described above, it is evident that it is difficult to recognise the same sample of students in different national contexts when considering the terms used in the analyses. Nevertheless, some resemblance has emerged such as distinguishing between students with average intellectual functioning and those with impairments to their intellectual functioning. 
In response to all these diverse interpretations, the OECD adopted three cross-national categories for a group of students who are provided with additional resources to help with their studies: students with disabilities, difficulties and disadvantages (OECD, 2007). Students with disabilities or impairments are viewed in medical terms as organic disorders attributable to organic pathologies (e.g. in relation to sensory, motor or neurological defects). Students with difficulties are defined as students with behavioural or emotional disorders, or specific difficulties with learning. Students with disadvantages are defined as arising primarily from socio-economic, cultural and/or linguistic factors (ibid.).

However, the conceptualisation and definition of learning difficulties remains a big issue to be tackled in the future. Considering all the definitions presented above for the purpose of this paper, the term 'learning difficulties' will be used to signify the broadest understanding of students who have any kind of difficulties related to learning regardless of their origin and severity since analyses of the relationship between learning difficulties and ESL most often do not include a precise definition of the terminology to enable us to distinguish between different backgrounds of the phenomena. Although there is no universal definition of students with learning difficulties, authors (European Agency, 2016; Korhonen, Linnanmäki, \& Aunio, 2014; Kortering \& Braziel, 1998; NESF, 2001) agree that this group of students belongs to "vulnerable groups" that are at high risk of low achievement and ESL - as already indicated in the introduction.

\section{Learning difficulties and ESL}

As described, there is no single 'cause' of ESL. Instead, multiple risk factors have been recognised that interact with each other and operate at various levels of young people's ecologies. Factors relate to individual characteristics, family background, schools, education systems and wider social and economic conditions (European Agency, 2016). Related to these factors, ESL is largely characterised by a lack of academic success and low motivation for school work (Lan \& Lanthier, 2003) which are also among the main characteristics of students with learning difficulties (Filippatou \& Kaldi, 2010). In fact, all students with special educational needs (SEN) are more likely to have lower attainments in school, poorer relationships and emotional and behavioural difficulties and to be at greater risk of ESL than their peers (Hakkarainen, Holopainen, \& Savolainen, 2016). It has been widely analysed and proven that, overall, young people with any kind of special 
educational needs achieve less than their peers and are more likely to truant and be excluded from school and therefore to be ESLers than their peers (Rogers, 2016).

Wagner and Davis (2006) show that students with learning disabilities and students with emotional and behavioural disorders experience disproportionately higher drop-out rates than other students with special needs. Also among adults of working age, those with a disability are roughly half as likely to have degree-level qualifications than those without disabilities (EHRC, 2011). The drop-out rate for all students in the USA, for example, is 7\%; for students served under the Individuals with Disabilities Education Act (IDEA) it is 21.1\%; while for the subset of students served under the IDEA with emotional disturbance the drop-out rate climbs to $38.7 \%$ (Child Mind Institute, 2016).

The prevalence of ESL among students with learning difficulties indicates there is a strong connection between the two phenomena but that other factors are also significantly related to ESL, and it is evident that learning difficulty by itself does not explain the reasons for ESL more than the other factors.

Special educational needs (SEN) or disability status may not offer an explanation for ESL over and above that provided by other risk factors, but nonetheless it is closely associated with those factors. In other words, students identified as having SEN are disproportionately more likely to experience factors that increase the risk for ESL (European Agency, 2016). Students with SEN are more likely than their peers to experience low levels of engagement, or to experience rapid decreases in engagement, and hence to leave school (Janosz, Archambault, Morizot, \& Pagani, 2008). These are related both to students' individual characteristics and their family characteristics (SES, support provided by the family to the student etc.)

Among the risk factors for ESL the school context is also regarded as important, especially when considering students with learning difficulties. Several students with learning difficulties indicated they did not feel engaged and connected to the school since the traditional programmes and teachers had failed to meet their needs (Palladino et al., 200o). It has been stated that students are less likely to drop out of schools where the relationships between teachers and students are consistently positive (Lee \& Burkam, 2001). The relations between teachers and students have an especially strong effect on students with learning difficulties, their learning outcomes and their motivation to stay in school (Shaddock, 2007). It may 
matter less in which setting students are included than whether they find that setting supportive (European Agency, 2016). Therefore, it is very important to establish provisions that would empower teachers and other educators with competencies to meet different students' needs.

Accordingly, one could argue that there are both learning difficulties by definition that are hindering these students from performing well or staying engaged in schools as well as the education system that does not support them in meeting their needs. Thus, there is a great need to act accordingly and take action to enable these students to reach their potential. The question remains of whether education facilities are able to make appropriate provisions for every student with different learning difficulties, disabilities and special educational needs to succeed. Actions regarding the prevention of ESL for students with learning difficulties would need to focus on several different issues in order to cope with the multiple factors leading to ESL, including their individual needs and motivation.

\section{How to support students with learning difficulties to prevent ESL}

\section{Research-based considerations}

The European Agency for Special Needs and Inclusive Education (2016) suggests that many types of interventions to reduce ESL are likely to work if introduced with sufficient quality and sufficient attention to local and individual circumstances. However, single-strand interventions are not the most effective way forward. There is a need for a broad range of actions focused on students, their schools and their families and the opportunity structures which shape their choices.

Efforts to reduce ESL among students with learning difficulties or even special educational needs students in general should therefore focus on offering an individually designed high level of support and different opportunities regarding all circumstances related to the individual student's educational experiences and motivation, including both the student's individual needs and characteristics, their background and also the teachers' and education system's characteristics.

Combatting the risks for ESL among young people identified as having SEN and/or a disability involves ensuring that:

- $\quad$ these young people have an appropriately high level of support; 
- their transitions are planned carefully;

- their families are involved; and

- there actually are appropriate high-quality education opportuni-

ties available to them (European Agency, 2016).

Regarding this, some approaches should include careful monitoring of the students and recognising those in risk followed by early individualised interventions based on the specific needs of each student with learning difficulties. The European Agency for Special Needs and Inclusive Education (2016) suggests that individualised academic support together with social, emotional and behavioural interventions should be implemented.

Several of the actions listed below can be considered while discussing the probability of reducing ESL among the learning difficulties population. As already indicated, these measures are welcomed for preventing ESL in general. But they are considerably more important for students with learning difficulties since by definition they are each more likely to experience more risk factors for ESL than their peers without learning difficulties.

A significant reduction of ESL requires fundamental changes in curriculum design processes, workflow design, and staff training; it demands creative use of technology and the development of partnerships with key stakeholders. ESL prevention needs to be built into existing programmes and newly created programmes also need to be designed (Smink \& Schargel, 2004) for students with learning difficulties and for teachers' educational and professional development. There are several issues that must be considered when planning new approaches for the education of students with learning difficulties in order to reduce their ESL prevalence.

Drop-out and ESL rates have been linked to the characteristics of the curriculum and instruction. Typically, the focus has been on an adapted curriculum and upgrading teachers' skills by providing training in student-centred, active pedagogy/instruction. Less often, the curriculum content itself is challenged. The lesson that has been learned is that adapting a curriculum which is not relevant or is not teaching functional skills in the first place does little to motivate students to stay in school (Peters, 2007).

Since the importance of individualised academic support has already been highlighted, it is evident that educators should also consider adapting the curriculum especially for an individualised education plan for students with learning difficulties in order to include more topics that are interesting and motivating for them. As the changes in the workflow design (where the 
school coordinates the information flow, services and systems to support the prevention of ESL) are also suggested as an important approach for reducing ESL, the importance of the contemporary suggestions of educators' professional development approaches regarding learning difficulties which propose a whole-school approach is obvious.

The whole-school approach has been emerging as the approach that is the most presentable for inclusive education in general and the most supportive for students with learning difficulties. Basic principles of wholeschool approaches include participation and collaboration (Peters, 2007). In this approach, the entire school community (school leaders, teaching and non-teaching staff, learners, parents and families) engages in a cohesive, collective and collaborative action to tackle ESL, with strong cooperation with external stakeholders and the community at large (European Commission, 2015).

Attitudes to learning difficulties in general and to teaching students with learning difficulties also constitute a critical challenge in the struggle to reduce ESL among students with learning difficulties. Traditional approaches focus on teacher attitudes in classrooms. But contemporary training programmes are also beginning to target other groups such as students with learning difficulties themselves, their peers and their parents (Peters, 2007). The whole-school approach covering teachers' professional development, the students with learning difficulties, their peers and other stakeholders thus seems to hold most potential for cutting ESL. Some best practices are presented below.

\section{Good practices}

Several approaches/good practices have been recognised as successful in preventing ESL among students with learning difficulties.

One of these approaches is called Cognitive Behavioural Interventions. This was recognised as an effective approach to help students with disabilities stay in school by reducing aggressive behaviours of students and it has shown its effectiveness across different educational environments, disability types, ethnicities and genders. With this approach, students learn strategies that promote self-regulation, increase positive behaviour and reduce inappropriate behaviour, and it simultaneously provides educators with information to assist in implementing those strategies. Using cognitive-behavioural interventions can substantively lessen the kinds of problem behaviours that frequently result in school suspensions and/or expulsions 
that subsequently lead to ESL (Riccomini, Bost, Katsiyannis, \& Zhang, 2005; Cobb, Sample, Alwell, \& Johns, 2005).

A prevention programme called "Check and Connect" is a comprehensive prevention programme designed to enhance students' engagement at school and has also been successful among students with disabilities and learning difficulties. The "Check" component uses consistent monitoring of students at risk of dropout (e.g. course failures, tardiness, missed classes, absenteeism, detention and suspension) and then the "Connect" component involves programme staff giving individualised attention to students in partnership with other school staff, family members and the community through academic support, in-depth problem-solving, and coordination with community services (Institute of Education Sciences, 2015).

Some interventions also tackle approaches for specific learning difficulties. For example, based on their findings Korhonen et al. (2014) suggest interventions for students with learning difficulties in mathematics that target both skills and the academic self-concept of students. Such an approach is Schema Broadening Instruction (i.e. Fuchs et al., 2009) which incorporates elements (praise, feedback) that aim to enhance the specific or general academic self-concept of students. Instruction based on schema theory encourages students to develop a schema for each problem type but also teachers need to be shown how to formulate such instruction.

Analyses of these approaches also confirm that students with learning difficulties are in need of receiving additional and specific academic support and simultaneously the support that tackles their self-concept (both general and academic) and motivation. Many forms of interventions are likely to be effective, although the quality of implementation and sensitivity to specific individual (or local) circumstances are important.

\section{Conclusion}

Students with special educational needs and learning difficulties are more likely than their peers without learning difficulties to experience low levels of engagement, or to experience rapid decreases in engagement (Janosz et al., 2008), they are more likely to have lower achievements (Hakkarainen et al., 2016) and therefore are more at risk for ESL (European Agency, 2016). But ESL is a complex phenomenon and other factors are also interrelated, such as family, SES, ethnicity, school support etc., which should all be considered when planning an intervention for a student with learning 
difficulties at risk of ESL with an emphasis on influencing the above-mentioned features.

In order not to put students at further risk of ESL, schools should be identifying and supporting at-risk children with prevention programmes. A widely deployed, integrated system of evidence-supported, school-based mental health and preventive services is needed (Child Mind Institute, 2016) so as to reduce the probability of poor achievements, low levels of engagement and related to that also ESL. It was determined that the relationship of students with their teachers and the whole-school approach are especially important when discussing students with learning difficulties in terms of preventing ESL. By definition, learning difficulties hinder their learning process (that in turn leads to low academic performance and ESL) but also the system and methods used do not enable these students to reach their potential. Therefore, not only should the empowerment of teachers and other educators through professional development be considered but other stakeholders are also an important issue to focus on while planning changes in systematic approaches for reducing ESL levels among students with learning difficulties.

Several intervention programmes and approaches have proven to be effective regarding preventing students with learning difficulties from leaving school early, such as Cognitive Behavioural Interventions concentrating on reducing students' problem behaviour (Riccomini et al., 2005; Cobb et al., 2005), the Check and Connect intervention focusing on monitoring and providing timely support (Institute of Education Sciences, 2015) and Schema Broadening Instruction focusing on improving students' problem-solving approaches and self-concept (Fuchs et al., 2009). These and other best practices can be used to establish a programme that would be effective in particular local and individual circumstances for reducing the risk factors for students with learning difficulties becoming ESLers.

\section{References}

Buttner, G., \& Hasselhorn, M. (2011). Learning disabilities: Debates on definitions, causes, subtypes, and responses. International Journal of Disability, Development and Education, 58, 75-87.

Child Mind Institute. (2016). Children's Mental Health Report. Retrieved from https://childmind.org/report/2016-childrens-mental-health-report/

Children and Families Act. (2014). Retrieved from http://www.legislation.gov. uk/ukpga/2014/6/contents/enacted 
Cobb, B., Sample, P., Alwell, M., \& Johns, M. (2005). Effective interventions in dropout prevention: A research synthesis. The effects of cognitivebehavioral interventions on dropout for youth with disabilities. Clemson, SC: National Dropout Prevention Center for Students with Disabilities, Clemson University.

EHRC. (2011). Support and aspiration: A new approach to special educational needs and disability. Department of Education. Retrieved from https:// www.gov.uk/government/publications/support-and-aspiration-a-new-approach-to-special-educational-needs-and-disability-consultation

Equality Act. (2010). Retrieved from http://www.legislation.gov.uk/ ukpga/2010/15/contents

European Agency for Special Needs and Inclusive Education. (2016). Early School Leaving and Learners with Disabilities and/or Special Educational Needs: A Review of the Research Evidence Focusing on Europe. (A. Dyson and G. Squires, eds.). Odense, Denmark.

European Commission. (2015). A whole school approach to tackling early school leaving. Policy messages. Brussels: European Commission. Retrieved from http://ec.europa.eu/dgs/education_culture/repository/education/policy/ strategic-framework/expert-groups/documents/early-leaving-policy_en.pdf

Eurydice. (n.d.). Description of national education systems - France. Retrieved from https://webgate.ec.europa.eu/fpfis/mwikis/eurydice/index. php/France:Special_Education_Needs_Provision_within_Mainstream_ Education

Filippatou, D., \& Kaldi, S. (2010). The effectiveness of project-based learning on pupils with learning difficulties regarding academic performance, group work and motivation. The International Journal of Special Education, 1, 17-26.

Fuchs, L. S., Powell, S. R., Seethaler, P. M., Cirino, P. T., Fletcher, J. M., Fuchs, D., ... Zumeta, R. O. (2009). Remediating number combination and word problem deficits among students with mathematics difficulties: A randomized control trial. Journal of Educational Psychology, 101(3), 561-576.

Geary, D. C. (2006). Learning disabilities in arithmetic: Problem solving differences and cognitive deficits. In H. L. Swanson, K. R. Harris \& S. Graham (Eds.), Handbook of Learning Disabilities (pp. 199-212). New York: Guilford Press.

Hardie, E., \& Tilly, L. (2012). An introduction to supporting people with a learning disability. London, Thousand Oaks: Sage Publications. 
Hakkarainen, A. M., Holopainen, L. K., \& Savolainen, H. K. (2016). The impact of learning difficulties and socioemotional and behavioural problems on transition to postsecondary education or work life in Finland: A five-year follow-up study. European Journal of Special Needs Education, 31(2), 171-186.

Institute of Education Sciences (2015). What Works Clearinghouse Intervention report: Check and connect. USA Department of Education. Retrieved from https://ies.ed.gov/ncee/wwc/Docs/InterventionReports/wwc_checkconnect_050515.pdf

Janosz, M., Archambault, I., Morizot, J., \& Pagani, L. S. (2008). School engagement trajectories and their differential predictive relations to dropout. Journal of Social Issues, 64, 21-40.

Korhonen, J., Linnanmäki, K., \& Aunio, P. (2014). Learning difficulties, academic well-being and educational dropout: A person-centred approach. Learning and Individual Differences, 31, 1 - 10.

Kortering, L. J., \& Braziel, P. M. (1998). School dropout among youth with and without learning disabilities. Career Development for Exceptional Individuals, 22, 61-74.

Lan, W., \& Lanthier, R. (2003). Changes in students' academic performance and perceptions of school and self before dropping out of schools. Journal of Education for Students Placed at Risk (JESPAR), 8(3), 309-332.

Lee, V. E., \& Burkam, D. T. (2001). Dropping out of high school: The role of school organization and structure. Retrieved from http://civilrightsproject. ucla.edu/research/k-12-education/school-dropouts/dropping-out-of-highschool-the-role-of-school-organization-and-structure/lee-role-school-organization-2001.pdf

Mercer, C. D., \& Pullen, P. C. (2005). Students with learning disabilities, 6th edition. Upper Saddle River, NJ: Merrill-Prentice Hall.

NESF. (2001). Early School Leavers. Report No. 24, Dublin: The Stationery Office.

NESSE. (2010). Early school leaving: Lessons from research for policy makers. Brussels: European Commission. Retrieved from www.nesetweb.eu/ sites/.../early-school-leaving-report.pdf

OECD. (2007). Students with disabilities, learning difficulties and disadvantages policies, statistics and indicators. OECD Publishing: Paris.

Opp, G. (1992). A German perspective on learning disabilities. Journal of Learning Disabilities, 25, 351-360. 
Oxford English Dictionary (b.d.). Retrieved from https://en.oxforddictionaries. com/definition/learning_difficulties

Palladino, P., Poli, P., Masi, G., \& Marcheschi, M. (200o). The relation between metacognition and depressive symptoms in preadolescents with learning disabilities: Data in support of Borkowski's model. Learning Disabilities Research and Practice, 15,142-148.

Peters, S. (2007). Inclusion as a strategy for achieving education for all. In: Florian, L. (ed.). The SAGE handbook of special education (pp. 117-130). London, Thousand Oaks: Sage Publications.

Riccomini, P. J., Bost, L. W., Katsiyannis, A., \& Zhang, D. (2005, August). Cognitive behavioral interventions: An effective approach to help students with disabilities stay in school. Effective interventions in dropout prevention: A practice brief for educators, Volume 1, Number 1. Clemson, S. C.: National Dropout Prevention Center for Students with Disabilities, Clemson University.

Rogers, L. (2016). Disengagement from education. Institute of Education Press, London.

Shaddock, A. J. (2007). Improving learning outcomes for all students: Strategies for teachers who don't claim to be super heroes. Keynote address to the University of Sydney "Successful Learning Conference", Harold Park Conference Centre, Glebe, Sydney. Retrieved from https://sydney.edu. au/education_social_work/professional_learning/resources/papers/ ShaddockA_07_paper_SLC.pdf

Smink, J., \& Schargel, F. (2004). Helping students graduate: A strategic approach to dropout prevention. New York: Eye on Education.

Taanila A., Yliherva A., Kaakinen M., Moilanen I., \& Ebeling H. (2011). An epidemiological study on Finnish school-aged children with learning difficulties and behavioural problems. International Journal of Circumpolar Health, $70,59-71$.

Wagner, M. (1991). Dropouts with disabilities: What do we know? what can we do? A Report from the National Longitudinal Transition Study of Special Education Students. Menlo Park, Calif: SRI International.

Wagner M., \& Davis M. (2006). How are we preparing students with emotional disturbances for the transition to young adulthood? Findings from the National Longitudinal Transition Study-2. Journal of Emotional and Behavioral Disorders, 14, 86-98. 



\subsection{7 \\ The Role of Career Guidance in ESL}

Urška Štremfel

\section{Synopsis}

Career guidance (with appropriate methods, contents, early provision, the actors involved) can overcome two important (individual) ESL risk factors - the lack of relevance of schooling and the lack of educational/career aspirations. The systematic development of career management skills helps potential ESLers perceive their schooling as a meaningful part of their lifelong personal, social and career development.

\section{Summary}

Research findings show that ESLers often cite the lack of their schooling's work and life relevance as a factor in their ESL (e.g. Hooley et al., 2011) and that young people with uncertain occupational aspirations or ones misaligned with their educational expectations are considerably more likely to become ESLers (Yates et al., 2011). There is a growing international consensus (Eurydice, 2014; Kraatz, 2014; OECD, 2003; Oomen \& Plant, 2014) that these two important (individual) risk factors for ESL can be successfully overcome by providing appropriately organised and implemented career guidance in schools.

The article presents career guidance as a promising measure for dealing with ESL (Eurydice, 2014; Kraatz, 2014; OECD, 2003; Oomen 
\& Plant, 2014). It shows how successfully developed career management skills (CMS) (defined as "a range of competences which provide structured ways for individuals (and groups) to gather, analyse, synthesise and organise self, educational and occupational information, as well as the skills to make and implement decisions and transitions" (ELGPN, 2010)) that result from career guidance help students at risk of ESL understand and internalise the connections between school and work and become more actively engaged in their academic tasks (Hamilton \& Hamilton, 1994; Solberg et al., 2002). The article also provides a review of theoretically and empirically considered successful career guidance approaches, which may create a stimulating learning environment for the development of CMS by: a) using appropriate (e.g. individual/group, curricular/extracurricular) methods; b) providing necessary contents (advice and support, skills development, information provision); c) its early introduction and provision through the entire educational path; and d) the cooperation and coordination of various stakeholders in its delivery. The article concludes by stating that appropriately organised and implemented career guidance (provided as either a separate or integrated educational activity) holds great potential in helping students at risk of ESL look beyond their immediate limitations and perceive their schooling as a meaningful part of their lifelong personal, social and career development.

Key words: career guidance, career management skills, relevance of schooling, career aspirations, ESL

\section{Introduction}

From adolescence to young adulthood, young people are exploring different identities and considering possibilities for their future but, at the same time, they are aware of the barriers that may hinder the fulfilment of their plans (Gottfredson, 1981). Planning for the future (including anticipated school completion and employment) is recognised as an important developmental task in adolescence (Blustein, Juntunen, \& Worthington, 2000; Erikson, 1968). Various empirical studies (e.g. Armstrong \& Crombie, 2000; Messersmith \& Schulengberg, 2008) reveal the important role of positive future-oriented cognitions in adolescents' latter (educational and/or occupational) attainment. 
Various research studies reveal there is a small but significant share of adolescents who express uncertainty regarding their aspirations and expectations for their future. Further, while most endorsed their commitment to the value of education, adolescents with uncertain intentions reported greater ambivalence about the relevance of continued schooling for their own lives compared to those who planned to continue in school (Croll, Attwood, Fuuler, \& Last, 2008). This is especially significant for low-achieving students, who are recognised as a potential ESL group. The study by Yates et al. (2011) finds that young people with uncertain occupational/career aspirations or ones misaligned with their educational expectations are considerably more likely to become ESLers by the age of 18 .

In these days of economic crisis and a dynamic labour market, career paths cannot be accurately predicted during schooling (Blossfeld, 2005; Gutman, Schoon \& Sabates, 2012). Transitions from school to work are clearly influenced by a very wide range of social, economic and education-system-level factors. However, school does have a formative impact on young people's ability to form career-oriented goals and successfully manage their transition from school to work (Creed \& Gagliardi, 2014). Although schools are not the only influence on young people's careers, they can and do exert an important influence on young people's approach to their career (Hooley, Marriott, \& Sampson, 2011). Strong and well-developed career guidance systems available to all learners have been identified as a promising measure in this regard. Council Conclusions (2015) state that a lack of career management skills may encourage learners to leave education prematurely. Similarly, the European Commission (2015) and CEDEFOP (2010) identified career guidance as one of the most important approaches for preventing ESL.

The main aim of the article is to present career guidance and career management skills as a promising measure for addressing ESL. First, conceptualisations and definitions of career guidance and career management skills are introduced. Second, selected ESL risk factors from the career development perspective are presented (namely, lack of relevance of schooling and lack of educational/career aspirations). Third, the article attempts to provide an answer regarding how to organise and implement career guidance (methods, activities, contents, the actors involved) to be effective in preventing ESL. The conclusion summarises the key findings. The article considers the dominant discussions in the field based on the presumption that individuals (ESLers) are responsible for their own educational and 
career development. The ways in which this prevailing idea is questioned (by considering that individual low educational/career aspirations and the lack of schooling's relevance are also affected by family socio-economic background, the quality of educational provision and the general social and economic situation in a country) is not a focus of this article.

\section{Methodology}

To address the article's aims, the following methods are employed: (a) an analysis of relevant literature and secondary sources. Within this framework, we conducted a literature search of the scientific EBSCOhost and Web of Science online research databases. The main key words for searching the relevant scientific literature were: early school leaving, career guidance, career management skills, relevance of schooling, educational aspirations, career aspirations; and (b) an analysis of formal documents and legal sources at the EU and national levels (EU official documents in the field of educational policy, non-official documents, press releases), an analysis of the national policy documents (e.g. legislation, strategies, reports) in EU member states.

\section{What is career guidance? Career guidance and career management skills}

Several theoretical approaches adopt different perspectives (e.g. trait and factor theory, opportunity structure theory, developmental theory, social learning theory, constructivist theory, community interactions theory, career learning theory) to explain how the individual's career decisions are actually made in practice (for a review, see Lovšin, 2016). Influenced in particular by the developmental theory, the social learning theory and the trait and factor theory, and to some extent also the opportunity structure theory, in the 1970s Law (1999) developed a comprehensive counselling model called D-O-T-S:

- $\quad$ D - Decision learning - learning about types of decision-making and the factors that must be considered;

- $O$ - Opportunity awareness - discovering opportunities for education, training, employment, learning about careers and the world of work in general; 
- $\quad T$ - Transition learning - learning the skills needed to make the transition between different levels and types of education, transition to the labour market etc.; and

- $\quad S$-Self-awareness - identifying one's traits, interests, knowledge, capabilities and talents etc.

In addition to focusing on the individual's traits and competencies, the model is centred on taking into account the individual's personal experiences when it comes to changing the traits (developmental theory), and the connections between the individual's decisions and opportunities presented within their social environment (opportunity structure theory). By taking the developmental theory into account, the model assumes that what is vitally important for the individual's career is not a single act of making the right decision, but the developmental aspect that lasts a lifetime. The skills acquired by individuals through learning in all of these four areas are referred to as career management skills (CMS). This crucial paradigm shift from a one-off decision to the lifelong nature of one's career also results in a redefinition of the role of (career) counsellors. In this sense, the main task of counsellors has transformed from being someone who matches workers with jobs, trainers, educators and mentors who encourage learning in those individuals they provide advice to. In that framework, their counselling work is understood as lifelong career guidance (Kohont et al., 2011: 28; in Lovšin, 2016).

After considering contemporary theoretical perspectives on career guidance and the DOTS model, which understand career guidance as a lifelong process of awareness of oneself and one's opportunities and learning about decisions and transitions, different definitions of career guidance have been developed within the European context.

The most elaborate definition and explanation is found in a resolution of the Council of the EU (2004, p. 2):

In the context of lifelong learning, guidance refers to a range of activities that enables citizens of any age and at any point in their lives to identify their capacities, competences and interests, to make educational, training and occupational decisions and to manage

1 Transitions, as the most important life changes, are recognised as the most risky factor for ESL (e.g. Downes, 2014). A meta-analysis by Baker and Taylor (1998) concluded it was possible to demonstrate that career development interventions help students successfully manage their transition phases and play an important role in the young person's further personal, social and career development. 
their individual life paths in learning, work and other settings in which these capacities and competences are learned and/or used.

Sultana (2012) explains that CMS (as a result of lifelong career guidance) is a particularly Anglo-Saxon term in origin, but in his opinion Council Resolution (2004) and several renderings of its definition seem to have followed its French translation (acquisistion de la capacité de s'orienter), which overlaps with the notion of self-guidance. ${ }^{2}$ Thomsen (2014, p. 5) explains that the understanding of CMS differs between countries and sees as one of the most encompassing definitions the following one developed in Nordic countries: "Career competences are competences for self-understanding and self-development; for exploring life and the worlds of learning and work; and for dealing with life, learning and work in periods of change and transitions. Career competences involve being aware, not only of what you do, but also what you could do, and of how individuals are formed by their daily activities and their actions while simultaneously affecting their own opportunities for the future".

After considering differences between member states, the European Lifelong Guidance Policy Network (ELGPN, 2014, p. 14) broadly defines CMS as "a range of competences which provide structured ways for individuals (and groups) to gather, analyse, synthesise and organise self, educational and occupational information, as well as the skills to make and implement decisions and transitions".

The above brief review of how lifelong career guidance and CMS are conceived shows it should not be exclusively understood as the support given to students in choosing which education or career option to take, but that it equally involves psychological counselling and the provision of additional learning support (also see Robertson, 2013). Career guidance may directly benefit well-being via the provision of a helping relationship, emotional support, building up confidence or beliefs in one's competence, promoting optimism via identifying future goals, and defining vocational identity (Robertson, 2013: 259). ${ }^{3}$ In this way, guidance should interrelatedly empower students for their career, personal and social development (see Blount, 2012; Štremfel \& Lovšin, 2016). for managing their own careers.

3 For an insight into the relationship between psychological problems and career choice problems among adolescents, see Kunnen (2014). 


\section{How can CMS overcome selected ESL factors? The lack of relevance of schooling and career aspirations as ESL risk factors}

Various factors at the individual, school and system level have been identified as being related to ESL. Research shows that students' well-developed career competencies (appropriately supported at all levels) are an important protective factor for ESL (Meijers, Kuijpers, \& Gundy, 2013). It is recognised that career education mainly addresses two important and interrelated (individual) risk factors for ESL: the lack of relevance of schooling and the lack of career aspirations. Different studies (e.g. Hamilton \& Hamilton, 1994; Lamb \& Rice, 2008; Schargel \& Smink, 2001; Solberg et al., 2002) also pointed to various other positive effects of career education ${ }^{4}$ in this regard: overcoming the sense of disconnection, improving one's learning motivation, increasing personal and social competencies and self-esteem, acquiring a range of knowledge and skills related to employment and work, raising academic achievement and consequently enhancing school completion and reducing drop outs.

\section{Lack of relevance of schooling}

One main reason that young people leave school early is identified as failing to perceive the relevance of their school education (perceived lack of suitability of curricula) for their everyday life, interests and career prospects (Byrne \& Smyth, 2010). ACTE (2007) reports that many students lose their interest and motivation in education because the curriculum does not seem to have real-world applications. Academic knowledge is often presented in isolation instead of in a way that shines a spotlight on how the subject is useful in the real world. ACTE explains these findings with the results of focus groups made up of dropouts aged 16-24, with $47 \%$ saying they dropped out of high school because the classes were not interesting (boring) and $69 \%$ saying they did not feel motivated. When referring to these two findings, the report states that the respondents consistently noted how

4 In the literature, the relationship between career guidance, orientation and education has been obfuscated by semantic confusions (for a review, see Watts (2013). In this paper, we follow his definitions and distinctions which explain that career guidance (as defined in the previous chapter) includes three main elements: career information, career counselling and career education, whereas career education is understood as part of the educational curriculum, in which attention is paid to helping groups of individuals develop the competencies they need to manage their career development. 
they had felt that school did not seem relevant. The most illustrative is the statement by one student explaining: "they make you take classes in school that you're never going to use in life" (ACTE, 2007). Similar results emerge from a 2006 poll of at-risk USA (California) 9th- and 1oth-graders where it was found that six in 10 respondents were not motivated to succeed at school. Of those students, more than $90 \%$ said they would have been more engaged in their education if the classes had helped them acquire skills and knowledge relevant to their future careers.

Research results show that holding a negative perception of the importance of education and its relevance to 'real life', contained in the frequently expressed question "Why do I have to learn this?", brings important implications for the (lack of) motivation and interest for school and consequently ESL. In order to prevent such a negative perception, it is thus necessary that learning and work involve activities that absorb students and give them opportunities to use their skills, and a sense of control. Benefits may be enhanced to the extent that the activities are personally meaningful and well matched with their individual interests, values and abilities (Robertson, 2013: 258). The role of properly implemented (career) education is therefore to help students understand the relevance of learning for their future life and career prospects.

\section{Lack of career aspirations}

Various research findings demonstrate the importance of clear educational and occupational aspirations for ensuring engagement in school. ${ }^{5}$ For example, Davies, Lamb and Doecke (2011), in addition to achievement (poor prior learning experiences, absences from school and poor language and literacy skills), refer to aspiration (an absence of career plans, poor knowledge of labour market opportunities and how to educationally access them, and limited networks) as the main factors that trigger disengagement from school and consequently ESL. Staff, Harris, Sabates and Briddell (2010) argue that young people uncertain about their desired future occupation may be more likely to change majors, transfer from one school to another, spend more time finishing a post-secondary degree, or drop out of school. Drawing on the British Cohort Study, Yates et al. (2011) found that young men and women born in 1970 who were uncertain about their future career

5 Despite these different research results, Yates (2008) warns that due to the complex and heterogeneous group of ESLers the relationship between holding uncertain aspirations and drifting into ESLer status is not simple. 
aspirations when they were 16 years old were nearly three times more likely to spend 6 months or longer not in employment, education or training between the ages of 16 and 18 .

Career education intended to help students develop an optimistic plan and outlook for their future prospects is an effective way to address ESL (Suh, Suh, \& Houston, 2007) and is particularly important in determining success in later life (Nguyen \& Blomberg, 2014). Sikora and Saha (2011) found a strong relationship between having clear and ambitious occupational plans in high school and high-status employment by the age of 25 years. The absence of such plans was shown to be detrimental to later occupational attainment.

The importance of career aspirations for finishing schooling and being engaged in school tasks may be explained by Miller and Brickman's (2004) model of future-oriented motivation and self-regulation. They contend that students' distal future goals (e.g. career goals) influence the adoption of proximal sub-goals (e.g. finishing schooling) in the service of the future goals; that the proximal goals lead to perceptions of instrumentality on the part of students exposed to learning tasks (e.g. taking classes, learning a subject); and that perceived task instrumentality, in turn, leads to proximal task-oriented self-regulation and helps determine the individual's level of engagement in those tasks (Tabachnick, Miller, \& Relyea, 2008). The importance of future-oriented motivation for adolescents' behaviours and their adult educational attainment, in support of the theoretical notion that future-oriented cognitions affect behaviour and play an influential role in shaping life trajectories, was also highlighted by Beal and Crockett (2010) and discussed by Haug and Plant (2015).

Different studies (e.g. Galliott, Graham, \& Sweller, 2015) have in particular examined the career aspirations of disadvantaged and low-achieving (at risk of ESL) students. James (2002) argues that students with a disadvantaged background are less likely to recognise the value of higher education than other students, and that students from a lower socioeconomic background set their sights lower than their peers. In their econometric analysis, Homel and Ryan (2014) recognise that aspirations have a positive impact on Year 12 completion for all students, regardless of indigenous or socioeconomic status. Thomson and Hillman (2010) stated that having a plan helps the transitions of all young people, especially those who do not perform well in the early years of secondary school. Therefore, sustained efforts are needed to improve their awareness of what might be 
possible for them (Nguyen \& Blomberg, 2014). This also confirms Rothman and Hillman's (2008) findings that lower-achieving students report that career advice was more useful. They conclude this indicates that career advice programmes are valued by young people who are more vulnerable when transiting from one educational level to another and from school to work, and that career advisors should continue to provide support, especially to these young people.

\section{How to provide career guidance that is effective in preventing ESL?}

In this section, we present different approaches to career guidance that have proven to be successful in preventing ESL (recognising the relevance of schooling and boosting the career aspirations of at-risk students) according to theoretical viewpoints, the results of empirical studies and analysis of good practices.

Career education should include several varied methods and activities, many of which point to the importance of broadening the scope of educational and vocational career decisions in a lifelong perspective. A combination of a wide range of curricular and extracurricular activities as well as individual and interactive group approaches should assure that career education is provided to all learners and simultaneously tailored to their particular needs (Eurydice, 2014; Lamb \& Rice, 2008). Different service-delivery concepts have been shown to be successful in this regard: individual approaches (individual guidance and counselling, mentoring, coaching, tutoring, tools for self-assessment, competence portfolio), adaptation of the curriculum (career games, sessions with prospective employers, workshops for learning interview skills, writing a curriculum vitae), external placements in workplaces (work experience programmes, job shadowing), extracurricular activities (thematic summer camps, job fairs), online services (web portals, online learning platforms, apps) (Botnariuc, Goia, Căpita, \& Iacob, 2016; European Commission, 2013; Eurydice, 2014; Kraatz, 2014). All of such structured activities aim to encourage students at risk of ESL to see their career in terms of lifelong development, and to look beyond their immediate limits with a view to creating a higher level of meaningfulness on their current and future educational paths (Oomen \& Plant, 2014: 14).

High quality guidance activities should provide young people with appropriate content. Taking CMS into consideration, it is important that career education: a) provides advice and support to students to enable them 
to make the right choices relative to their educational and work opportunities; b) helps students identify their own interests, strengths and weaknesses, develop their individual skills and aptitudes and thereby enables them to manage their future educational and career choices; and c) provides students with sufficient information about educational and career pathways to make informed choices. It is crucially important that all three dimensions are equally pursued and provide a holistic approach to supporting individuals on their educational/career path (European Commission, 2013; Eurydice, 2014).

Although career guidance is recognised as a prevention, intervention and compensation measure in tackling ESL (Eurydice, 2014), various research findings highlight the importance of its early introduction and provision throughout the entire educational path. For example, a review of theory and recent research related to educational and occupational aspirations reveals that important career development processes may occur well before adolescence. In fact, tentative educational plans may be formed in early elementary school (Wallace, 2007), with career preferences being evident as early as kindergarten (Trice \& King, 1991). Nguyen and Blomberg (2014) even realised that educational (and career) aspirations measured at age 15 do not change markedly as students grow older, suggesting they are formed early and that interventions later in the senior secondary school years may be too late to influence educational (and career) aspirations. Berthet (2013) claims the career decision is not a one-off event and represents a string of events making up a sequence within a series of career-decision cycles during the entire educational path. It is therefore crucial that career guidance is not only concentrated at the (critical) transition points (from primary to secondary, from secondary to tertiary education), which is currently a general practice in most EU countries (Eurydice, 2014) but is organised as a developmental process on all education system levels.

Understanding career guidance as a developmental process (and not the once-off provision of information about further educational/career options) requires the cooperation and coordination of various stakeholders in its delivery. Here the role played by various actors within the school context is particularly important. Although career counsellors in most EU countries are recognised as the key persons responsible for providing career guidance in schools (Eurydice, 2014), they cannot cover all of the above-mentioned important (developmental) activities and contents (Carr \& Galassi, 2012; Knight, 2015). As important adults in students' lives, 
teachers represent an integral part of the development of children's and adolescents' personality, and can thus importantly contribute to their personal development and the development of strategies for preventing and resolving problems in school or at a later time in life (Masten \& MottiStefanidi, 2009), and can also be of significant value in children's decisions on their own career paths (Vršnik Perše, 2016). The active role of parents (also in cooperation with school staff) in providing at-risk students with conditions (emotional support, advice) in which they will be able to accomplish this important developmental task as well as they can is equally and crucially important (Rutar Leban, 2016).

To ensure the provision of holistic and effective career guidance, cross-sectoral cooperation, especially entailing actors from the world of employment and work (public guidance services, public employment services, NGOs, private enterprises), is vital (European Commission, 2015; Eurydice, 2014: 99-100). In this framework, the idea of work-based learning has been especially relevant in the EU setting in the last few years. Providing opportunities at an early stage to allow students to experience the world of work, for example via 'tasters' in enterprises, can help them understand job demands and employers' expectations (European Commission, 2015: 2021). ACTE (2007) and the European Commission (2013) even contend that workplace experience can motivate at-risk students to continue their education and become more focused on their future career choices.

\section{Conclusion}

The role of career education and guidance in preventing ESL is widely acknowledged in EU discourse and academic discussions. Career management skills, defined as a range of competencies which provide structured ways for individuals (and groups) to gather, analyse, synthesise and organise self-related, educational and occupational information, as well as the skills needed to make and implement decisions and transitions (ELGPN, 2010) among others, especially target two (individual) ESL risk factors (lack of relevance of schooling and lack of educational/career aspirations). A key assumption of the current career development research and practice is that students who have a career plan and are able to understand and internalise the connections between school and work will be more actively engaged in their academic tasks and be more likely to succeed at school (Hamilton \& Hamilton, 1994; Solberg et al., 2002). 
Different strategies have been identified as being especially successful in implementing career guidance as a tool for preventing ESL. The most effective career development seems to be applied early and maintained throughout the individual's schooling and delivered in a holistic and multi-modal way (Hooley et al., 2011; Kraatz, 2014). Although the important, positive role of career guidance is broadly acknowledged in critical transition phases, it should not be exclusively concentrated at these points and needs to be fully integrated into curricular and extra-curricular activities from the early stages of education. This can be assured by applying various different methods (individualised approaches, interactive group approaches, online services, work-based learning) and contents (advice and support, development of skills, provision of information). Whilst career counsellors have an important role to play in career education by empowering learners in the acquisition of skills to pursue their interests, competencies and career aspirations, effective career education also needs to mobilise a wide range of stakeholders, including adults important to students (e.g. teachers and parents) and actors from the world of employment (employment services) and work (business, employers) (European Commission, 2015).

As such, career education does not teach concrete competencies (CMS) as much as it can provide rich, varied and pedagogically appropriate experiences and environments that facilitate students' development (Atkinson \& Murrell, 1988). It provides an important tool to help potential ESLers become autonomous creators of their own career and life path.

\section{References}

ACTE (The Association for Career and Technical Education). (2007). Career and Technical Education's Role in Dropout Prevention and Recovery. Issue Brief. Alexandria: ACTE.

Armstrong, P., \& Crombie, G. (200o). Compromises in adolescents' occupational aspirations and expectations from Grades 8 to 10. Journal of Vocational Behavior, 56(1), 82-98.

Atkinson, G. Jr., \& Murrell, P. H. (1988). Kolb's experiential learning theory: A metamodel for career exploration. Journal of Counseling \& Development, $66,374-377$.

Baker, S., \& Tayor, J. (1998). Effects of career development interventions: A meta-analysis. The Career Development Quarterly, 46(4), 376-385. 
Beal, J. S., \& Crockett J. L. (2010). Adolescents' occupational and educational aspirations and expectations: Links to high school activities and adult educational attainment. Developmental Psychology, 46(1), 258-265.

Berthet, T. (2013). Any room for deliberation? Educational guidance in French schools. Critical Policy Studies, 7(3), 325-338.

Blount, T. (2012). Dropout prevention: Recommendations for school counsellors. Journal of School Counselling, 10, 1-33.

Blossfeld, H. P. (2005). Globalization, uncertainty and youth in society. London: Routledge.

Blustein, D. L., Juntunen, C. L., \& Worthington, R. L. (200o). The school-towork transition: Adjustment challenges of the forgotten half (pp. 435-470). In S. D. Brown \& R. W. Lent (Eds.), Handbook of Counseling Psychology (3rd Ed.). New York: Wiley.

Botnariuc, P., Goia, D., Căpița, L. \& Iacob, M. (2016). Preventing ESL through Career Guidance. Study of best practices. Retrieved from http://www. guidingcities.eu/wp-content/uploads/2016/o7/Study-on-Good-practices. pdf

Byrne, D., \& Smyth, E. (2010). No way back? The dynamics of early school leaving. Dublin: Liffey Press/ESRI.

Carr, C. V., \& Galassi, J. P. (2012). The role school counsellors believe they should adopt in dropout prevention. Journal of School Counselling, 1o, $1-34$.

CEDEFOP (European Centre for the Development of Vocational Training) (2010). Guiding at-risk youth through learning to work: Lessons from across Europe. Luxembourg: Publications Office of the European Union.

CEDEFOP (2014). Career guidance in unstable times: Linking economic, social and individual benefits. Briefing note. Brussels: CEDEFOP.

Council of the European Union (2004). Draft resolution of the Council and of the representatives of the Governments of the Member States meeting within the Council on Strengthening Policies, Systems and Practices in the field of Guidance throughout Life in Europe. Brussels: Council of the European Union.

Council of the European Union (2015). Council conclusions on reducing early school leaving and promoting success in school. Brussels: Council of the European Union. 
Creed, A. P., \& Gagliardi, R. E. (2014). Career compromise, career distress, and perceptions of employability: The moderating roles of social capital and core self-evaluations. Journal of Career Assessment, 23(1), 20-34.

Croll, P., Attwood, G., Fuller, C., \& Last, K. (2008). The structure and implications of children's attitudes to school. British Journal of Educational Studies, 56(4), 382-399.

Davies M., Lamb S. \& Doecke E. (2011). Strategic Review of Effective ReEngagement Models for Disengaged Learners, Department of Education and Early Childhood Development, Melbourne.

Downes, P. (2014). Towards a Differentiated, Holistic and Systemic Approach to Parental Involvement in Europe for Early School Leaving Prevention. Policy Recommendations Report for the EU Urbact, PREVENT project involving 10 European City Municipalities.

ELGPN (European Lifelong Guidance Policy Network) (2010). Lifelong Guidance Policies: Work in Progress - A Report of the Work of the European Lifelong Guidance Policy Network 20o8-2010. Jyväskylä: University of Jyväskylä.

ELGPN (2014). Lifelong Guidance Policy Development. Glossary. ELGPN Tools No. 2. Jyväskylä: University of Jyväskylä.

Erikson, E. H. (1968). Identity: Youth and crisis. New York: W. W. Norton.

European Commission (2013). Reducing early school leaving: Key messages and policy support. Final Report of the Thematic Working Group on Early School Leaving. Brussels: European Commission, Directorate-General for Education and Culture.

European Commission (2015). A whole school approach to tackling early school leaving. Education \& Training 2020, Schools policy. Brussels: European Commission, Directorate-General for Education and Culture.

European Commission/EACEA/Eurydice/Cedefop (2014). Tackling Early Leaving from Education and Training in Europe: Strategies, Policies and Measures. Eurydice and Cedefop Report. Luxembourg: Publications Office of the European Union.

Galliott, N., Graham, L. J., \& Sweller, N. (2015). Who struggles most in making a career choice and why? Findings from a cross-sectional survey of Australian high-school students. Journal of Psychologists and Counsellors in Schools, 25(2), 133-151.

Gottfredson, L. S. (1981). Circumscription and compromise: A developmental theory of occupational aspirations. Journal of Counselling Psychology, 28(6), 545-579. 
Gutman, L. M., Schoon, I., \& Sabates, R. (2012). Uncertain aspirations for continuing in education: Antecedents and associated outcomes. Developmental Psychology, 48, 1707-1718.

Hamilton, S. F., \& Hamilton, M. A. (1994). Opening career paths for youth: What can be done? Who can do it? Washington. DC: American Youth Policy Forum.

Haug, E. H. \& Plant, P. (2015). The potential role of career guidance and career education in combating early school leaving. Neveléstudomány, 2015(3), 5-15.

Homel, J. \& Ryan, C. (2014). Educational outcomes: The impact of aspirations and the role of student background characteristics. Longitudinal surveys of Australian youth research report no. 65. Adelaide: National Centre for Vocational Education Research.

Hooley, T., Marriott, J., \& Sampson, J.P. (2011). Fostering college and career readiness: How career development activities in schools impact on graduation rates and students' life success. Derby: International Centre for Guidance Studies, University of Derby.

James, R. (2002). Socioeconomic background and higher education participation: An analysis of school students' aspirations and expectations. Department of Education, Science and Training, Canberra.

Knight, L. J. (2015). Preparing elementary counsellors to promote career development: recommendations for school counsellor education programs. Journal of Career Development, 42(2), 75-85.

Kohont, A., Tacer, B., Hrovatič, D., Urbanc, K., Vidmar, T., Toličič Drobež, Ž., Jelenc Krašovec, S. Pečjak, S., Jurišević, M., Niklanovič, S., Dedić, S. and Bučar Markič, S. (2011). Terminološki slovarček - Karierne orientacije 2011. Ljubljana: Zavod RS za zaposlovanje.

Kraatz, S. (2014). Reform of educational systems: European policies for lifelong guidance to fight early school leaving and unemployment. European Parliament Briefing. Brussels: European Parliament.

Kunnen, E. (2014). The effect of a career choice guidance on self-reported psychological problems. Frontiers in Psychology, 5, Article 547.

Lamb, S., \& Rice, S. (2008). Effective intervention strategies for students at risks of early leaving. Melbourne: University of Melbourne: Centre for Post-compulsory Education and Lifelong Learning.

Law, B. (1999). Career-learning space: New-dots thinking for careers education. British Journal of Guidance \& Counselling, 27(1), 35-54. 
Lovšin, M. (2016). Theoretical frameworks of career guidance for pupils and students. In U. Štremfel, \& M. Lovšin (Eds.), Students' Career, Personal and Social Development: Perspectives, Approaches, Challenges (pp. 21-31). Ljubljana: Pedagoški inštitut.

Masten, A. S., \& Motti-Stefanidi, F. (2009). Understanding and promoting resilience in children: Promotive and protective processes in schools. In T. Gutkin \& C. Reynolds (Eds.), Handbook of School Psychology, 4th Edition (pp. 721-738). New York: Wiley.

Meijers, F., Kuijpers, M., \& Gundy, C. (2013). The relationship between career competencies, career identity, motivation and quality of choice. International Journal for Educational and Vocational Guidance, 13, 47-66.

Messersmith, E. E., \& Schulenberg, J. E. (2008). When can we expect the unexpected? Predicting educational attainment when it differs from previous expectations. Journal of Social Issues, 64(1), 195-211.

Miller, B. R. \& Brickman, J. S. (2004). A model of future-oriented motivation and self-regulation. Educational Psychology Review, 16(1), 9-33.

Nguyen, N. \& Blomberg, D. (2014). The role of aspirations in the educational and occupational choices of young people. Adelaide: National Centre for Vocational Education Research.

OECD (2003). Career guidance policy review. Paris: OECD Publishing.

Oomen, A., \& Plant, P. (2014). Early school leaving \& lifelong guidance. ELGPN Concept Note No. 6. Jyväskylä: European Lifelong Guidance Policy Network.

Robertson, P. J. (2013). The well-being outcomes of career guidance. British Journal of Guidance \& Counseling, 41(3), 254-266.

Rothman, S. \& Hillman, K. (2008). Career advice in Australian secondary schools: Use and usefulness. Longitudinal Surveys of Australian Youth (LSAY) Research Report. No. 53. Victoria: Australian Council for Educational Research.

Rutar Leban, T. (2016). Parents as adults with a significant impact on children's career paths. In U. Štremfel \& M. Lovšin (Eds.), Students' Career, Personal and Social Development: Perspectives, Approaches, Challenges (pp. 93101). Ljubljana: Pedagoški inštitut.

Schargel, F. P., \& Smink, J. (2001). Strategies to help solve our school dropout problem. Larchmont, New York: Eye on Education. 
Sikora J., \& Saha, L. J. (2011). Lost talent? The occupational ambitions and attainments of young Australians. Adelaide: National Centre for Vocational Education Research.

Solberg, V. S., Howard, K. A., Blustein, D. L., \& Close, W. (2002). Career development in the schools: Connecting school-to-work-to-life. The Counseling Psychologist, 30, 705-725.

Staff, J., Harris A., Sabates, R., \& Briddell, L. (2010). Uncertainty in early occupational aspirations: Role exploration or aimlessness? Soc Forces, 89(2), 659-683.

Suh, S., Suh, J., \& Houston, I. (2007). Predictors of categorical at-risk high school dropouts. Journal of Counseling and Development, 85, 196-203.

Sultana, R. G. (2012). Learning career management skills in Europe: A critical review. Journal of Education and Work, 25(2), 225-248.

Štremfel, U. \& Lovšin, M. (Eds.) (2016). Students' career, personal and social development: Perspectives, approaches, challenges (pp. 21-31). Ljubljana: Pedagoški inštitut.

Vršnik Perše, T. (2016). Empowering teachers for career guidance of children and adolescents. In U. Štremfel \& M. Lovšin (Eds.), Students' Career, Personal and Social Development: Perspectives, Approaches, Challenges (pp. 82-92). Ljubljana: Pedagoški inštitut.

Yates, S. (2008). Youth' career aspirations and socioeconomic outcomes in adulthood: A literature review. Discussion Paper 08-02. London: Centre for Research on the Wider Benefits of Learning, University of London.

Yates, S., Harris, A., Sabates, R., \& Staff, J. (2011). Early occupational aspirations and fractured transitions: A study of entry into 'neet' status in the UK. Journal of Social Policy, 40(3), 513-534.

Tabachnick, E. S., Miller, B. R. \& Relyea, E. G. (2008). The relationship among students' future-oriented goals and subgoals, perceived task instrumentality, and task-oriented self-regulation strategies in an academic environment. Journal of Educational Psychology, 10o(3), 629-642.

Thomsen, R. (2014). A Nordic perspective on career competence and guidance - Career choices and career learning. Nordic network for adult learning (NVL) \& ELGPN Concept note. Oslo: NVL.

Thomson, S., \& Hillman, K. (2010). Against the odds: Influences on the postschool success of 'low performers. Adelaide: NCVER.

Trice, A. D. \& King, R. (1991). Stability of kindergarten children's career aspirations. Psychological Reports, 68(3), 13-78. 
Wallace, O. S. (2007). What Were They Thinking? Decision-Making in the Experiences of College Students At Risk. NADE Digest, 3(2), 59-68.

Watts, A. G. (2013). Career guidance and orientation. In Revisiting global trends in TVET: Reflections on theory and practice (pp. 239-274). Bonn: UNESCO-UNEVOC International Centre for Technical and Vocational Education and Training. 



\subsection{8}

\section{The Role of Physical Activity in ESL}

Klaudija Šterman Ivančič

\section{Synopsis}

The socio-emotional well-being, learning behaviour and motivation of ESL students can be supported by including regular physical activity in prevention and compensation ESL programmes. Schoolcommunity collaboration, extracurricular sport activities, organised sport events and expressive practices are possible forms of such activities.

\section{Summary}

In the literature, the role of physical activity in ESL is mainly investigated in connection to the individual's health promotion and learning abilities. As studies (e.g. Share et al., 2013) show, ESLers lack awareness about the importance of physical activity in their lives and are on average less physically active than students included in the education system. Not only do physically active students choose healthier lifestyles, are physically and mentally healthier and tend to achieve better in schools, physical activity also plays an important role in supporting the individual's socio-emotional well-being (sense of belonging, self-efficacy, self-esteem etc.) (e.g. Castelli et al., 2014; OECD, 2010; WHO, 2011). Through ESL prevention and compensation activities such as extracurricular sport activities, organised sport events and usage of expressive practices within physical education and activities, we can help keep socially disadvantaged 
students off the street and support their learning processes by improving their self-esteem, social skills, strengthening their interpersonal relationships with other peers, teachers and the wider community, and addressing their problems with stress management, school failure, discrimination, communication difficulties and learning disabilities (e.g. Basich, 2006; Biddle, Mutrie, \& Gorely, 2015; Fedewa \& Ahn, 2011; Senlin, Haichun, Xihe, \& Ang, 2014; Strong et al., 2005; Taras, 2005). In order to achieve these positive effects, schools and the community should collaborate in organised action, physical activity should become an important part of every school and community-based (educational) programmes and teachers should rethink physical education activities so that, besides physical purposes, they more explicitly support the individual's social and emotional well-being by including body language expression, techniques of self-awareness (e.g. techniques of self-focused attention, perseverance of concentration) and interpersonal bonding (e.g. encouragement for affiliation via group sports). From this perspective, the importance of physical activity in reducing ESL is uncontested.

Key words: ESLers, physical activity, community learning, educational outcomes

\section{Introduction}

Being physically active is one of the most important steps in being physically and mentally healthy. Physical activity by itself reduces the risk of most chronic diseases, improves musculoskeletal health and psychological well-being (Centers for Disease Control and Prevention, 2009; WHO, 2011). In terms of academic achievement, physical activity has important positive effects on a student's concentration, memory, motivation and classroom behaviour (Castelli et al., 2014; McDonald, 2007) and helps reduce mental health problems such as anxiety and depression. All of the mentioned factors are important in the context of a student's academic involvement and persistence (Strong et al., 2005).

In the literature, we can find reciprocal effects between physical activity and ESL. On one hand, the World Health Organization (2011) and the OECD (2010) state the important connection between an individual's years of involvement in the educational process and his health and physical activity. Those with higher education levels have increased levels of physical activity and individuals with lower education levels are at risk for adopting 
lifestyle behaviours that can have a potentially negative impact on health, such as diet, lower levels of physical activity, and drug abuse. This means (Limerick Health Promotion, 2008; Share, Hennessy, Stewart-Knox, \& Davison, 2013) that young people who stay in the school setting have longer access to positive school cultures, supportive environments and healthy policies that can impact positively on their health and lifestyle choices (e.g. healthy eating, physical activity etc.). ESLers are deprived of this. In this manner, a lower level of physical activity is one of the negative consequences of an individual's ESL and can also be considered one of the characteristics of students who left the educational setting too early (ibid.). This is the connection between ESL and physical activity that is most often described in the literature.

On the other hand, the link between physical activity and ESL also goes in the other direction, i.e. physical activity leading to lower levels of ESL. The aim of this article is to look at theoretical and empirical investigations that consider physical activity as a characteristic of ESLers and as an important prevention activity that can be strengthened in order to help lower ESL rates; we explain via which mechanisms physical activity can contribute to low ESL. In this context, we will pay special attention to the effects of physical education on the individual's physical and mental health, the effects on learning processes and ways that the physical activity of ESLers can be bolstered through different community-based approaches to education and improving the individual's social and emotional health.

\section{Methodology}

In the process of reviewing the literature in field of interaction between physical activity and ESL, we first conducted a literature search of the scientific EBSCOhost online research databases (Academic Search Complete, ERIC, PsycARTICLES, PsycBOOKS, PsycINFO, and SocINDEX with Full Text databases) and the Web of Science database. In order to review project reports and practical implications of community-based programmes that encourage physical activity in ESL, we also searched for related results online. The main key words initially used in both cases were: physical activity and academic achievement, physical activity and ESL, physical education for ESLers, physical health of ESLers, physical education and emotional well-being, and active teaching methods of community learning. In the first step, we noticed a very limited number of search results in response to the mentioned terms that would consider all three: the role of physical 
activity, ESL and community-based activities. We therefore expanded our search to the field of sociology of physical education in which those approaches are largely incorporated. We also examined references cited in the reviewed articles, educational programme brochures, and project reports. Texts that were taken into account had to meet the following criteria: the topic needed to address the role of physical activity in tackling ESL and improving the individual's social and emotional health or the topic had to describe ways in which physical activity can be implemented in community-based supportive practices. The conclusions are primarily based on findings from theoretical and research articles and evaluations of different already performed projects/programmes on this topic.

\section{Mechanisms linking physical activity with educational outcomes and ESL}

It is already well established (e.g. Basch, 2011; Dwyer, Sallis, Blizzard, Lazarus, \& Dean, 2001; McDonald, 2007; Singh, Uijtdewilligen, Twisk, van Mechelen, and Chinapaw, 2012) that regular physical activity has positive effects on the individual's educational outcomes. It affects different areas of the individual's functioning that contribute to better adaptation in a school setting. Here we would like to expose those aspects of physical activity that can be encouraged through school and community-based education in order to successfully tackle ESL rates.

Some authors (e.g. Shephard, 1997) point to an important aspect of physical education's role in the lives of students, i.e. the attitude to sport and physical activity is already shaped in early years of the individual's educational path. There is evidence from cross-sectional (e.g. McDonald, 2007; Schendel, 1965; Schun \& Brookover, 1970) and longitudinal studies (e.g. Shephard, Lavallée, Volle, LaBarre, \& Beaucage, 1994) that the likelihood of becoming active and sustaining a regular exercise programme during the years after compulsory education depends on the individual's early experience and exposure to physical activity (Godin \& Shephard, 1990). A similar association also exists between physical activity and cognitive functioning (e.g. Shephard et al., 1994; Teasdale, Sorensen, \& Stunkard, 1992). Systematically supported physical activity in the early years of schooling is therefore a crucial prevention step in supporting well-being and academic achievements of all students in later years.

Physical activity by itself increases the individual's physical and mental health by enabling the body and mind to relax and produce hormones 
that contribute to better mood, physical and emotional health (Paluska, 200o). In this way, it can help individuals with coping mental disorders such as depression and anxiety (Folkins \& Sime, 1982; Paluska, 2000; Weir, 2011), disorders that tend to recur more often in the ESL student population (Limerick Health Promotion, 2008). On the other hand, studies (e.g. Share et al., 2013; WHO, 2011) show that ESLers tend to be less physically active than students who stay in the education system. In their report on ESLers and nutrition, Share and colleagues (2013) point out that ESLers often lack understanding of the important role of physical activity in their lives. It is therefore critical for community-based programmes to incorporate at least basic forms of physical activity into their programmes, encourage ESLers to participate and share awareness about the importance of being physically active since regular physical activity is the most fundamental way to help increase students' physical and mental well-being.

Besides that, physical activity affects students' emotional and social well-being which is also very important in addressing ESLers. Different studies (e.g. Centers for Disease Control and Prevention, 2010; Fedewa \& Ahn, 2011; Strong et al., 2005; Taras, 2005) have already confirmed that physical activity helps shape a student's positive behavioural patterns that promote persistence and academic achievement such as a sense of belonging, tolerance between students, mutual respect, cooperation, and healthy competitiveness. It has also been established (e.g. Epstein et al., 2002; Schargel \& Smink, 2004) that increasing the individual's sense of belonging and acceptance plays an important part in tackling ESL rates. It is therefore crucial for both schools and community-based educational programmes to organise and promote physical activity among students in a way that encourages acceptance and cooperation among all students. Physical activity in the sense of organised group sports activities where every individual has an important role is one of the points where this can be supported.

Another important aspect within the connection between a student's educational outcomes and physical activity is motivation for learning and persisting in educational tasks. Physical activity always involves the restraint of one's efforts and teaches us that persistence is needed to achieve goals. In this way, it increases the individual's self-esteem and perceived self-efficacy (Basich, 2006; Bowker, Gadbois, \& Cornock, 2003; Biddle, Mutrie, \& Gorely, 2015; Senlin, Haichun, Xihe, \& Ang, 2014), an area that 
is a very important part of a student's academic motivation and an aspect where ESLers often need encouragement (Benard, 1991).

Share (Share et al., 2013) also states that activities related to physical activity in mainstream and alternative education focus mainly on curriculum-based approaches to introducing physical activity to students. Approaches tend to be passive and not geared to the different needs of young people in different education settings. Especially for ESLers, there is a great need for innovative and practical responses that are enjoyable for them and address their social and emotional needs such as their lack of a sense of belonging to a peer group or community (Cederberg \& Hartsmar, 2013; Frostad, Pijl, \& Mjaavatn, 2014), lack of motivation for learning (Schargel \& Smink, 2004) and maladaptive school behaviour in general (ibid.). The social and emotional well-being of ESLers through physical education is therefore an area that needs improvement.

\section{Physical activity in community learning}

In the previous chapter, we established how physical activity is important for the physical, mental, emotional and social well-being of ESLers. It is an important point where those aspects can be strengthened and encouraged as part of prevention and compensation strategies to reduce ESL rates where both schools and community-based programmes play an important role. One of the most recognisable ways in the literature and policy documents (e.g. European Commission, 2013; Luthar, Shoum, \& Brown, 2006; Zarret \& Eccles, 2009) to achieve this are extracurricular activities after and outside school and different community-based programmes that offer learning, social and emotional support to ESLers.

Extracurricular physical (sports) activities after and outside school can raise self-esteem, improve motivation and support learning processes (Cornelißen \& Pfeifer, 2007; Zarret \& Eccles, 2009). Another important aim of such activities in the context of ESL is to keep children off the street. Studies (e.g. Cornelißen \& Pfeifer, 2007) show that free time allocated to activities such as sports reduces the chance of students participating in more harmful activities (e.g. watching television, smoking, drinking etc.) and, as such, has an indirect positive effect on educational productivity. The importance of preventive extracurricular and out-of-school sport activities for preventing ESL is therefore uncontested.

In certain areas, schools might also be the only institution available with sports facilities (e.g. gyms, sports equipment) that allow for non-formal 
sport activities outside school hours. Opening the school to educators other than teachers is therefore essential to overcome the reluctance towards education of ESLers (WHO, 2006).

It is also very important that local organisations (educational, youth, sport) recognise the potential for physical activity of ESLers in their surroundings (connecting with nature, local environment) and in this way try to increase the sense of belonging of ESLers to their community through sports (Cavill, Foster, Oja, \& Martin, 2006; WHO, 2006). Physical activity in the form of different sport events (e.g. sports days) is also an excellent way that community educators can include the families of ESLers into their educational process through enjoyable and low-cost activities. By connecting ESLers with their local environment, community organisations and different social contexts (families, schools and peers) through different sport events and activities, their social and cultural capital can be systematically strengthened.

The community-based approach to education and learning tends to be collaborative and, besides conventional teaching methods, is based on informal teaching methods (e.g. role play, socio-drama, participative action research, movement, art etc.) (Ancosan, 2009). As such, it has even greater potential to incorporate different forms of learning techniques that involve movement and physical activity and thus develop and support the social and emotional well-being of ESLers. Those practices (e.g. Accrochage Scolaire Services project, 2013; The Forum Theatre against ESL project, 2013; Facing Youth unemployment from its very beginning project, 2014) are often referred to in the literature as expressive practices and are aimed to improve the self-knowledge and self-esteem of groups at risk, including ESL students. With help of such techniques, students are able to realise and address their problems with self-esteem, self-confidence, stress management, previous negative experiences with school failure, discrimination, behavioural problems, learning disabilities, school phobias and communication difficulties. Through body language expression and techniques of self-awareness (e.g. role playing, socio-drama), they more easily express their needs and problems. By harmonising their body and language expression, they increase their capacity for attention and concentration. In such learning settings, they also experience acceptance from others, interpersonal bonding and practice mindfulness and empathy towards others and oneself. 


\section{Conclusions}

According to the literature and projects review, we can draw on several important conclusions concerning physical activity's positive role in tackling ESL (see Figure 15).

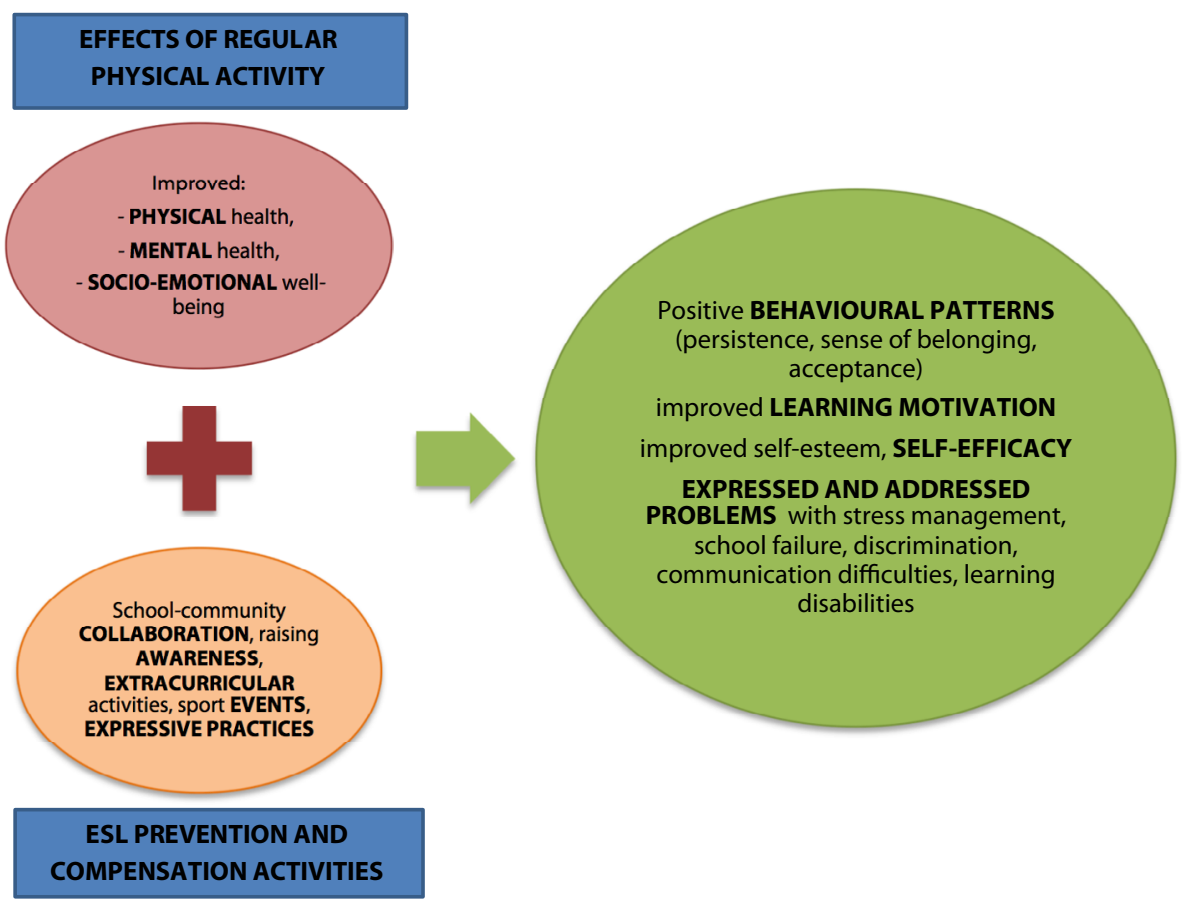

Figure 15. Physical activity's different beneficial effects on ESL

First, physical activity has an important impact on a student's physical and mental health. It is one of the basic human needs and has beneficial effects on the human as a whole (Teixeira, Carraça, Markland, Silva, \& Ryan, 2012). It relaxes the body, helps with coping depression and anxiety, stimulates the student's concentration and learning motivation. Through sports, ESLers can learn how to be active and achieve small goals which stimulate them to also be more confident and effective in other areas of life, including education. This means it is crucial to incorporate regular physical activity in all ESL educational prevention and compensation programmes since just by carrying out basic forms of physical activity has an important impact on a student's physical, mental and also emotional health and supports the educational process on different levels. Moreover, since it has been found that 
ESLers are on average less physically active, it is also crucial to raise their awareness about the importance of being physically active.

Another important aspect of physical activity is its impact on a student's socio-emotional well-being. ESLers often lack a sense of acceptance and belonging to peers, the school and also the community as a whole. The first important step in raising their sense of belonging through sports is the cooperation between schools and the wider community (sport facilities, adult education organisations, health organisations and employers). WHO (2011) points out that the local environment has a vital role in promoting sport and physical activity since it is mainly in the local setting that opportunities to be physically active are provided. Taking a life course approach and offering physical activity in different settings, including schools and workplaces, is essential to the promotion of physical activity, especially for vulnerable groups such as ESLers. Extracurricular sport activities organised in schools and organised sport events are therefore an important way to strengthen ESLers' social and cultural capital, their sense of belonging and acceptance, to include their parents in educational activities and to keep ESLers off the street in socio-economically disadvantaged environments.

Besides including and carrying out regular basic forms of physical activity in ESL prevention and compensation programmes, it is important to include practices (e.g. socio-drama, role playing etc.) that enable students to express themselves through movement and body language. In this way, physical activity can be used as a tool to improve ESLers' self-awareness and help them address their problems with school failure, discrimination, learning disabilities, communication difficulties and behavioural problems. Drawing on encouraging results from different initiatives (e.g. Accrochage Scolaire Services project, 2013; The Forum Theatre against ESL project, 2013; Facing Youth unemployment from its very beginning project, 2014), it may be worthwhile to rethink school physical education activities for teens in the context of ESL prevention and compensation programmes so that, apart from physical and practical purposes, they include body language expression, rhythmic-expressive activities or techniques of self-awareness. Unfortunately, some authors (e.g. Castelli et al., 2014) point to the fact that in today's educational practice there is a big tendency to reduce physical activity in schools in order to increase students' productivity and academic achievements in other areas of learning. Such an approach contradicts with the findings described in this article and therefore 
represents an even greater risk factor for ESLers. This points to a need for the educational community to realise the importance of physical activity in the process of teaching and learning in order to increase the cognitive, social and emotional well-being of all students.

\section{References}

Accrochage Scolaire Services project (2013). Retrieved from http://www.enseignement.be/index.php?page $=23721$

Ancosan (2009). Principles of community education. Retrieved from www.ancosan.com/wp.../AnCosan-Shanty-Principles-of-Education

Basich, C. W. (2006). Thesis: The impact of physical activity and sports on self-esteem in adolescent girls. Marietta: Marietta College.

Basch, C. E. (2011). Physical activity and the achievement gap among urban minority youth [Special issue]. Journal of School Health, 81(10), 626-634.

Benard, B. (1991). Fostering resiliency in kids: Protective factors in the family, school, and community. Oregon: Western Regional Center for Drug-Free Schools and Communities.

Biddle, S. H. J., Mutrie, N., \& Gorely, T. (2015). Psychology of physical activity ( $3^{\text {rd }}$ Edition). Oxon: Routledge.

Bowker, A., Gadbois, S., \& Cornock, B. (2003). Sports participation and self-esteem: Variations as a function of gender and gender role orientation. Sex Roles, 49(1), 47-58.

Castelli, D. M., Centeio, E. E., Hwang, J., Barcelona, J. M., Glowacki, E. M., Calvert, H. G., \& Nicksic, H. M. (2014). The history of physical activity and academic performance research: Informing the future. In J. P. Bauer (Ed.) The relation of childhood physical activity to brain health, cognition, and scholastic achievement (119-148). Charlotte: Information Age Publishing.

Cavill N., Foster C., Oja P., \& Martin, B. W. (2006). An evidence-based approach to physical activity promotion and policy development in Europe: Contrasting case studies. IUHPE - Promotion and Education, 13(2), 20-27.

Cederberg, M., \& Hartsmar, N. (2013). Some aspects of early school leaving in Sweden, Denmark, Norway, and Finland. European Journal of Education, $48,378-389$.

Centers for Disease Control and Prevention (2010). The association between school based physical activity, including physical education, and 
academic performance. Atlanta, GA: USA Department of Health and Human Services.

Cornelißen, T., \& Pfeifer, C. (2007). The impact of participation in sports on educational attainment: New evidence from Germany. IZA Discussion Paper, November 2007.

Dwyer, T., Sallis, J. F., Blizzard, L., Lazarus, R., \& Dean, K. (2001). Relation of academic performance to physical activity and fitness in children. Pediatric Exercise Science, 13, 223-237.

Epstein, J. L., Sanders, M. G., Simon, B. S., Salinas, K. C., Rodriguez Jansorn, N., \& Van Voorhis, F. (2002). School, family, and community partnership: Your handbook for action. Thousand Oaks: Corwin Press, Inc.

European Commission (2013). Reducing early school leaving: Key messages and policy support. Brussels: Directorate-General for Education and Culture.

Facing Youth unemployment from its very beginning project (2014). Retrieved from: http://www.projects.aegee.org/yue/

Fedewa, A. L., \& Ahn, S. (2011). The effects of physical activity and physical fitness on children's achievement and cognitive outcomes: A meta-analysis. Research Quarterly for Exercise and Sport, 82(3), 521-535.

Folkins, C. H., \& Sime, W. E. (1981). Physical fitness training and mental health. American Psychologist, 36(4), 373-389.

Frostad, P., Pijl, S., \& Mjaavatn, P. (2014). Losing all interest in school: Social participation as a predictor of the intention to leave upper secondary school early. Scandinavian Journal of Education Research (online): http:// dx.doi.org/10.1080/00313831.2014.904420.

Godin, G., \& Shephard, R. J. (1990). Use of attitude-behavior models in exercise promotion

in relation to body mass index of adult males. Journal of Human Biology, 64, 99-106.

Limerick Health Promotion (2008). Health impact assessment of early school leaving, absenteeism and truancy. Limerick: Limerick Regeneration Agency.

Luthar, S. S., Shoum, K. A., \& Brown, P. J. (2006). Extracurricular involvement among affluent youth: A scapegoat for "ubiquitous achievement pressures"? Developmental Psychology, 42(3), 583-597. 
McDonald, M. C. (2007). Active transport to school: Trends among USA schoolchildren, 1969-2001. American Journal of Preventive Medicine, 32(6), 509-16.

OECD (2010). Health at a glance: Europe 2010. OECD Publishing. Retrieved from http://dx.doi.org/10.1787/health_glance-2010-en

Paluska, S. A., \& Scwenk, T. L. (200o). Physical activity and mental health. Sports Medicine, 29, 167-180.

Schargel, F. P., \& Smink, J. (2004). Helping students graduate: A strategic approach to dropout prevention. Larchmont, NY: Eye on Education.

Senlin, C., Haichun, S., Xihe, Z., \& Ang, C. (2014). Relationship between motivation and learning in physical education and after-school physical activity. Research Quarterly for Exercise and Sport, 85, 468-477.

Share, M., Hennessy, M., Stewart-Knox, B., \& Davison, J. (2013). Early school leavers and nutrition: A needs assessment from a nutrition perspective. Dublin: Safefood, The Food Safety Promotion Board.

Shephard, R. (1997). Curricular physical activity and academic performance. Pediatric Exercise Science, 9, 113-125.

Shephard, R. J., Lavallée, H., Volle, M., LaBarre, R., \& Beaucage, C. (1994). Academic skills and required physical education: The Trois Rivières experience. CAHPER Research Supplement, 1 (1), 1-12.

Singh, A., Uijtdewilligen, L., Twisk, J. W., van Mechelen, W., \& Chinapaw, M. J. (2012). Physical activity and performance at school: A systematic review of the literature including a methodological quality assessment. Archives of Pediatrics \& Adolescent Medicine, 166(1), 49.

Strong, W. B., Malina, R. M., Cameron, J. R. B., Daniels, S. R., Dishman, R. K., Gutin, B. ... Trudeau, F. (2005). Evidence based physical activity for school-age youth. Journal of Pediatrics, 146, 732-737.

Strong, W. B., Malina, R. M., Blimkie, C. J., Daniels, S.R., Dishman, R. K., \& Gutin, B. (2005). Evidence-based physical activity for school-aged youth. Journal of Pediatrics, 146(6), 732-7.

Taras, H. (2005). Physical activity and student performance at school. Journal of School Health, 75(6), 214-218.

Teasdale, T. W., Sorensen, T. I. A., \& Stunkard, A. J. (1992). Intelligence and educational level in relation to body mass index of adult males. Human Biology, 64, 99-106. 
Teixeria, P. J., Carraca, E. V., Markland, D., Silva, M. N., \& Ryan, R. M. (2012). Physical activity and self-determination theory: A systematic review. International Journal of Behavioral Nutrition and Physical Activity, 78, 2-30.

The Forum Theatre against ESL project (2013). Retrieved from http://artemisszio. blog.hu/2014/o6/11/fotel_forum_theatre_against_early_school_leaving

Weir, K. (2011). The exercise effect. Monitor on Psychology, 42, 48-54.

World Health Organization (2011). Global recommendations on physical activity for health. Copenhagen: World Health Organization.

WHO Regional Office for Europe (2006). Promoting physical activity and active living in urban environments - the role of local governments. Copenhagen: World Health Organization.

Zarret, N., \& Eccles, J. (2009). The role of family and community in extracurricular activity participation: A developmental approach to promoting youth participation in positive activities during the high school years. In L. Shumow (Ed.) Promising practices for family and community involvement during high school (27-51). Charlotte: Information Age Publishing. 



\subsection{9}

\section{Critical Media Literacy:}

A New Tool and Pedagogy for Tackling ESL Ana Mlekuž

\section{Synopsis}

Critical media literacy helps understand how media construct messages, influence and educate audiences and impose messages and values. Five core questions verifying the understanding of these issues can be used as a tool for developing the critical thinking of students at risk of ESL so as to become empowered and active in transforming their educational and learning environment.

\section{Summary}

Critical media literacy can be used as a new tool for tackling ESL by developing critical thinking, discussing power structures and encouraging students to become active in changing their educational and learning environment, their lives and society (Halx, 2014; Dewey, 1963; Kincheloe \& McLaren, 1994). By using contemporary media messages included in music videos, movies, news etc., educators can easily relate and connect to students' lives, they can challenge students to critically think about the messages they are receiving and to actively oppose them (Kanpol, 1994; Kellner \& Share, 2004, 2005, 2007; Masterman, 1994). Critical media pedagogy is able to engage students who are marginalised, alienated, come from lowSES environments, have low achievements are at risk of early school leaving (ESL) (Duncan-Andrade \& Morrell, 2008; Kincheloe, 2007; Stringfield \& Land, 2002). 
By applying the five core questions of critical media literacy (Who created this message?; What creative techniques are used to attract my attention?; How might different people understand the same message differently?; What lifestyles, values and points of view are represented in - or omitted from - this message?; Why is this message being sent?), educators can teach critical thinking not only in the area of media, but also in any kind of communication (Erjavec, 2010; Kellner \& Share, 2005; Thoman \& Jolls, 2004). In such a way, educators can and should create an inclusive environment in which all students feel welcome and safe to express their own views. Students thus become empowered and gain strategies for how to transform their educational process (Kellner \& Share, 2007) and how to become active citizens - active creators of their own lives and their society (McInerney, 2009), which are all circumstances that reduce the risk of ESL.

Key words: media literacy, critical thinking, critical pedagogy, ESL

\section{Introduction}

Many surveys show that low-achievers doubt that the education they are receiving will have a positive impact on their lives (Bacolod \& Hotz, 2006; Duncan-Andrare \& Morrell, 2008; Halx \& Ortiz, 2011; Kincheloe, 2006), which often serves as the basis for their disinterest in school and sometimes even the decision to drop out of school and is especially common among students from marginalised groups and students with low SES. Therefore, it is evident that the need for a new, more student-sensitive, more student-focused and more relevant to students' lives pedagogy is needed. Halx (2014) argues that a new kind of pedagogy which proves to be successful among marginalised and low-SES students and includes all of the previously stated characteristics is pedagogy developing critical thinking skills (i.e. critical pedagogy), which is most evident in critical media literacy's curriculum (Kanpol, 1994). By using contemporary media messages included in music videos, movies, news etc., educators can relate and connect to students' lives, they can challenge students to critically think about the messages they are receiving and to actively internally and/or externally oppose them (Kellner \& Share, 2004, 2005, 2007; Masterman, 1994). Internally, by changing their self-perception and thus improving their self-esteem and consequently their motivation for learning. Externally, by showing their feelings, thoughts, dilemmas to their peers, teachers, parents and other 
members of society through different communication tools such as different media or a simple conversation. Moreover, it is important that educators encourage students to extend this kind of reasoning to all the messages they are receiving through any kind of communication (Thoman \& Jolls, 2004).

This article tries to explain why critical media literacy is suitable as a tool for developing critical thinking skills and thus preventing ESL. In the first part, we define media literacy and critical media literacy and explain why it is supposed to be successful in developing critical thinking skills. In the second part, it is explained how critical media literacy can be regarded as a preventive strategy against ESL. The last part of the article presents concrete strategies for teaching students critical media thinking and critical media analyses in order to prevent ESL. Moreover, in italics specific examples are presented of movie analysis and developing of critical thinking with the help of the five core questions of critical media literacy.

\section{Methodology}

Literature used for this article was found through scientific literature search engines such as ERIC, Emerald, Google Scholar, Science Direct, and ProQuest Dissertation \& Theses Global. The key words used were: media literacy; critical media literacy; critical pedagogy; critical thinking; dropout; marginalised groups; academic achievement. For the purposes of this article, scientific papers, online scientific books and some handbooks on the topic of critical pedagogy and critical media literacy were used.

\section{Media literacy: concepts and definitions}

Traditionally, media literacy was defined as the ability to analyse and appreciate literary works and to communicate effectively via good writing (Brown, 1998). With the development of media in the 1970s, it was extended to reading the text of film, television and other visual media. Since the term "media" nowadays may refer to art, billboards, computers, film, moving images, multimedia, music, oral and written language, television and social media, the concept and scope of media literacy has also become wider and more versatile (Gardiner, 1997; Meyrowitz, 1998). Buckingham (2003) therefore argues that media literacy is the knowledge, skills and competencies required to use and interpret media. UNESCO's definition is, however, more complex and defines media literacy as a process of the assimilation 
and employment of a media system's codes and operative skills required to properly use the technology on which these codes are based. Moreover, media literacy, as UNESCO understands it, should also encompass the capacity to access, analyse and evaluate the power of media messages and the capacity to communicate using all forms of media (television, film, radio, recorded music, press, Internet and other digital communication technology) (Perez Tornero \& Varis, 2010). Hobbs (1996) defines media literacy as a process of accessing and critically analysing media messages and creating new messages using media tools, whereas Rubin (1998) argues that media literacy means understanding sources of communication technology, the codes used, the messages produced and the selection, interpretation and impact of these messages.

As evident, two components of media literacy definitions are the most common - first, the awareness of the multitude of media messages and, second, a critical ability to analyse and question these messages (Hobbs, 2001; Silverblatt, 1995; Singer \& Singer, 1998).

Kellner and Share (2007) define four different approaches to understanding media literacy:

- The first approach is the so-called protectionist approach, which sees media audiences as passive victims and values traditional print culture over media culture. It tries to prevent addiction to media by cultivating an affection for high culture and its values and thus displaying all aspects of media and computer culture in a bad light.

- The second approach is media arts education, which assumes that learning how to construct media messages implicitly teaches media literacy.

- The third approach called media literacy movement defines media literacy as a series of communication competencies, including the ability to access, analyse, evaluate and communicate, and expands the notion of literacy to multiple forms of media.

- The fourth approach - the critical media literacy approach - includes aspects of all three approaches stated above, but puts emphasis on the critical analysis of the dominant ideology used in the media and highlights the importance of detecting prevailing dominant representations of gender roles, race, class and sexuality. Moreover, it expands the analyses to include social issues, 
issues of control and pleasure, while it promotes the production of alternative media forms and consequently develops critical thinking skills.

\section{Critical media literacy and the development of critical thinking}

Critical media literacy's curriculum is one of the most compatible curriculums for teaching students critical thinking (Kanpol, 1994). Critical media literacy encourages individuals to apply analytical tools to media practices, promotes critical thinking by encouraging them to examine connections among media, self and others and to understand the issues of power and the media's role in identity shaping (Buckingham, 1998; Lewis \& Jhally, 1998). Critical media literacy also provides a framework to understand media's impact on shaping beliefs, attitudes and behaviours (Brown, 1998; Kellner, 1995), sociocultural theories of learning and development (Garcia, 2005; Valenzuela, 2005) and critical pedagogy (Kincheloe, 2006). Critical media literacy helps individuals to expand their concept of literacy and develop higher order thinking skills (Hobbs, 1996; Kozma, 1991), which are necessary for developing critical thinking, collaboration and self-direction (Steinberg \& Kincheloe, 1998; Dweck, 200o) and are directly related to student achievement (Boske \& McCormack, 2011).

Teachers, students and other individuals are often not aware of media's educational potential and how they shape our reality as its pedagogy is frequently invisible and unconscious. Therefore, it is important to be aware of how media construct messages, influence and educate audiences and impose their messages and values (Kellner \& Share, 2005).

To sum up, critical media literacy establishes a critique of mainstream approaches to understanding media messages. Moreover, it is seen as a project which is a tool of democratic social change. This process combines critical inquiry of the media culture and cultural industries, which discuss issues of class, race, gender, sexuality and power. In addition, it promotes the creation of alternative media messages which are opposing the dominant hegemonic media (Kellner \& Share, 2007). Marginalised individuals, who are too often stereotyped or misinterpreted in the mainstream media such as the poor, minorities, low-achievers, individuals with behavioural and mental issues etc. who are at risk of ESL and even ESLers themselves (Gunn, Chorney, \& Poulsen, 2009), can use media and information technology through critical media pedagogy. Critical media pedagogy serves as 
a tool for empowerment in order to tell their stories and express their concerns either through different media projects in classes or in other communication outside of school (YouTube, Facebook, blogs, vlogs etc.). It is very important for these groups of individuals who do not have many opportunities to express their points of view to ventilate them (Kellner \& Share, 2005). On the other side, through this process the dominant group is given the opportunity to come across the social realities the marginalised groups are experiencing (Kellner, 2004; Kellner \& Share, 2005). Critical media analysis and the production of new media messages can thus serve as the basis for class or public discussion of different issues.

For example, successful students and teachers (as a dominant group) might not be aware of the different struggles low-achievers or students at risk of ESL (as a marginalised group) encounter. Through different learning projects, critical media pedagogy thus offers tools and an opportunity for marginalised students to present their stories, points of view and struggles to the dominant group (and vice versa) using different media. In this way, in addition to developing critical thinking skills, where students together critically analyse their own behaviour and the views of others in school, a welcoming school environment is created in which students feel safe to express their own feelings and views, feel more connected to their school and are thus at a lower risk for ESL.

As can be seen, critical media literacy helps all students, those belonging to marginalised groups such as minorities, low-achievers etc. and those belonging to the dominant groups, to see their own realities and the realities of the other group differently (Kellner \& Share, 2005).

\section{Implementing critical media literacy as an ESL prevention strategy in practice}

There are different ways for educators to teach students how to critically analyse and use the media and no rigid pedagogical models are suggested (Kellner, 2004). The orientations for teaching critical media literacy are instead interpretive reference points from which educators can base their strategies on. Educators should identify the elements and objectives and moreover should understand that principles and programmes may differ in varying contexts (Kellner \& Share, 2007). 
Based on Masterman's core concepts of media literacy ${ }^{I}$, the Centre for Media Literacy (CML) in its CML MediaLit Kit (Thoman \& Jolls, 2004) introduced five core questions to help educators teach media literacy (Kellner \& Share, 2007). Further, if applied correctly these five questions can help students (and the rest of the population) change the way they interact with and learn in today's media culture, their communities and their lives in general and can even help them to develop critical thinking and become active citizens (Erjavec, 2010; Kellner \& Share, 2005; Thoman \& Jolls, 2004).

\section{Key question 1: Who created this message?}

The first key question covers the principle of non-transparency and the realisation that all media messages are constructed (Kellner \& Share, 2005). This is the foundation of media literacy since it challenges the power of media which tend to present their messages as non-problematic and transparent. Media messages do not present reality as it is or a simple reflection of the world, they are created, shaped and positioned through a construction process that includes many decisions about what to include or exclude and how to represent reality (Erjavec, 2010; Kellner \& Share, 2005; Thoman \& Jolls, 2004). This concept helps students understand that media creators decide what to present and what to leave out, resulting in media shaping our knowledge and understanding of the world (Thoman \& Jolls, 2004).

Example: The movie Dangerous Minds ${ }^{2}$ is based on a true story of a white teacher and recounts her story of teaching problematic students (at risk of ESL) in an American context. The storyteller is a member of the

1 Key concept of media literacy is representation; key goal of media literacy is denaturalisation of media; media education is primarily investigative; media education is organised around core concepts, which use analytical and not substantive tools; media education is a lifelong process; media education tries to stimulate not only critical understanding but critical autonomy; effectiveness of media education can be measured by the ability of students to apply what they learned through media education (critical ideas and principles) to new situations and the amount of commitment, interest and motivation displayed by students; media education seeks to clarify the life-situations of students by stimulate the motivation, interest and enthusiasm generated by the media's coverage of topical events (Masterman, 1994).

2 This American movie is based on a true story of Louanne Johnson who is hired as a teacher in a high school in a poor area of the city where most of the students are African-American and Hispanic and at high risk of ESL due to their poverty-stricken, racially segregated, economically deprived environments. Most students' parents show little interest and enthusiasm in the education of their children. After a terrible reception from the students, Louanne tries many unconventional methods of teaching to gain the students' trust. 
dominant group. Students in the classroom, watching the film, should be encouraged to discuss to which group different characters in the movie (the teacher, the students etc.) belong - to the dominant or marginalised? Who are the members of the dominant and marginalised group in the movie and who could these be in other national contexts (for example other minorities in any given environment) or at their school/class? What are their common characteristics? Would the story be different if told from a different point of view - for example, by a member of a non-dominant group?

\section{Key question 2: What creative techniques are used to attract my attention?}

The second key question explores the codes and conventions used in media messages and is based on the assumption that all media messages are constructed using a creative language with all its rules (Thoman \& Jolls, 2004; Kellner \& Share, 2005). Media often present codes and stereotypes which put marginalised groups (workers, women, people of colour, also ESL students) in a subordinate position in contrast to the positive representation of bosses, the rich and successful students as natural and consequently reinforce the stereotypes and present them as a natural state (Kellner \& Share, 2005). Media education's goal is therefore to teach students to distinguish denotation (literal meaning) from connotation (associative, subjective meaning based on cultural and ideological codes) or, in other words, to distinguish what they see or hear from what they think or feel (Fiske, 1990), thus preventing messages being presented as natural when connotation and denotation become one.

Example: The Dangerous Minds movie strengthens the stereotype of the problematic student (ESLer) as a member of a minority or someone who comes from a deprivileged environment. Students should be encouraged to analyse whether all students who are members of minorities or come from poorer environments really are at a higher risk of ESL and should provide different examples from either real life or movies supporting or opposing this stereotype. Moreover, students should also discuss possible solutions to the problem of stereotyping ESLers.

\section{Key question 3: How might different people understand the same message differently?}

The third question's goal is to decode audiences. It is based on the assumption that different people experience the same media messages differently 
(Kellner \& Share, 2005; Erjavec, 2010). This question assumes the audience is active and there is a difference between the producers' coding of the media text and the recipient's decoding of the same media text (Hall, 1980). Each of the recipients has his/her own characteristics (age, gender, education, cultural upbringing etc.) which affect the interpretation of a media text and subsequently create the recipient's unique understandings (Thoman \& Jolls, 2004). It is precisely this that conclusion has contributed greatly to the notion that media literacy can empower audiences to be active in the process of creating meaning (Kellner \& Share, 2005; Erjavec, 2010).

Example: At this point, it is necessary to encourage all students (especially those at risk of ESL) to express their own understanding of the movie message and point out their different views and find reasons why they are different. Students should be encouraged to identify with other groups and think about how members or students at risk of ESL/different minorities/successful students/teachers understand the movie. They should compare and discuss their different views and therefore understand how these are emerging / being developed.

\section{Key question 4: What lifestyles, values and points of view are represented in - or omitted from - this message?}

The fourth question builds on the assumption that the media have embedded values and points of view in their messages (Kellner \& Share, 2005). Values become embedded in the message with the creator's decisions on a character's age, gender, race mixed with the lifestyles and behaviours portrayed. If the message is news, then values and points of view are embedded by the length of the message, which story goes first etc. The values included are unavoidably a reflection of the creator's values, attitudes and points of view (Thoman \& Jolls, 2004). Critical media literacy's aim is therefore to detect these embedded values and to doubt the prevailing ideology, bias and connotations of the explicit and implicit representations in the media. This kind of media analysis can also help to develop critical thinking and further questioning of the representation of race, class, gender, ethnicity etc. in media and other types of communication (Erjavec, 2010). Moreover, the awareness of embedded values in media or other messages increases the tolerance for differences in thinking and understanding the same message and helps in decision-making on whether to accept or reject the overall message (Thoman \& Jolls, 2004). 
Example: Dangerous Minds attempts to represent 'whiteness' (the dominant group) as the rationality, authority and cultural standards against the 'non-whiteness' (the marginalised group) as violence, chaos and failure. Students should be encouraged to think of other cases where similar representations of students at risk of ESL are visible not only from movies, but also from real life and how they can oppose them.

\section{Key question 5: Why is this message being sent?}

The last question tackles the motive or purpose of the media or any other message. This question is based on the assumption that media are organised to acquire profit and/or power (Erjavec, 2010; Thoman \& Jolls, 2004; Kellner \& Share, 2005). The main aim of this question is to determine the influence that financing, ego or ideology has on the message, which helps the message receiver appropriately respond to it and understand the reason it was sent (Thoman \& Jolls, 2004).

Example: All movies are filmed in order to make a profit and this is also the case of Dangerous Minds too. Students should, however, try to think of other reasons or if one of the reasons was also to present the issue of ESLers and how the movie could be changed so that this message becomes more evident (at this point, students should be warned not to use stereotyping or other risks presented through the other four core questions).

Critical media literacy educators should employ all five questions to address the problem of media representation and not only the ones that are most obvious, such as which techniques are used in the media message or how audiences react to the message. Further, educators should challenge their students to question widely accepted assumptions with oppositional interpretations as well as seeking alternative media with oppositional and counterhegemonic representations and messages. In addition, they should encourage their students to produce new media messages, which reflect their own points of view (Kellner \& Share, 2007). As a result, students learn about different views on addressed issues, are encouraged to discuss these issues and consequently possibly change their own knowledge, opinion and view on these issues. Moreover, students are encouraged to present their new messages through other public communication channels (such as YouTube, Facebook, blogs, vlogs etc.) and therefore participate in a wider public debate.

These five core questions of critical media literacy are used in practice for teaching critical thinking in many projects in countries around 
the world (Schofield \& Rogers, 2004; Hull, 2003; Guajardo, Guajardo \& del Carmen Casaperalta, 2008; Comber \& Nixon, 2005). One of such projects based on a critical media literacy framework included students of English as a second language course at a Los Angeles middle school with high ESL rates, where they analysed the media representation of their community and afterwards created their own positive media messages. By using a critical media literacy framework, the lessons became more inclusive for all types of communication and the relationship between information and power was addressed. However, what is most important is that students at risk of ESL were more engaged in new literacies with a critical perspective, and were able to increase their self-esteem, their sense of pride in their community, interest in school and desire to learn (Choudhury \& Share, 2012).

It can therefore be assumed that by developing critical thinking through critical media pedagogy students are empowered with tools to realise that low achievement in school or ESL is not something fixed, but created by different messages and that they have the power to recreate and change it. All of this is possible through project-based media production, which can be used not only in media lessons but also in other lessons ${ }^{3}$, for making analyses more meaningful and empowering as students acquire tools for responding and taking action on the social conditions externally by discussing their problems, views and dilemmas with others through different means of communication, and internally by changing their self-perception and improving their self-esteem and motivation for learning. As a consequence, students become empowered to transform their own educational process and become active citizens who actively create a more equal and democratic society (Kellner \& Share, 2007) as a far-reaching goal.

\section{Conclusion}

The article shows that critical media literacy's curriculum provides a platform for developing critical thinking skills, which is the basis for better decision-making during adolescence and adulthood and is significantly

3 Example: One of the West Wing episodes (So2E16) (https://www.youtube.com/ watch? $\mathrm{v}=\mathrm{vVX}$-PrBRtTY) where one of the plots revolves around the proposal by the fictional NGO to replace the familiar Mercator-projection map with an inverted version of the Gall-Peters Projection Map can be used in geography when learning about different world maps, mathematics when learning about projection, history when learning about the relationship between the Europe and the rest of the world, sociology when learning about the dominance and marginalisation etc. 
correlated to academic achievement (Marin \& Halpern, 2011; Taghva, Rezaei, Ghaderi, \& Taghva, 2014) and non-risk behaviour (unprotected sex, drug use, ESL etc.) (Marin \& Halpern, 2011). Critical media literacy encourages students to discover underlying elements such as power structures and gendered identities in different media messages (Alvermann \& Hagood, 2002) and encourages students to make new, different messages that oppose the dominant ideology (Kellner \& Share, 2007). With the help of the five core concepts or questions (Erjavec, 2010; Kellner \& Share, 2005; Thoman \& Jolls, 2004) students analyse media (and other) messages, create new messages and thus experience their own realities and the realities of others, different individuals (Kellner \& Share, 2005). By doing so in either the classroom or through other (more public) means of communication (such as blogs, vlogs, social media etc.), students learn about and discuss the realities of others and consequently gain knowledge and possibly change their views, opinions and behaviour, while they become more self-confident and motivated. It can be said that through critical media literacy students become empowered with strategies to become active and transform their educational process and environment and try to create a more democratic society (Kellner \& Share, 2007).

Nevertheless, we should be aware that enacting critical thinking through critical media literacy cannot solve or change the material conditions of students' lives (poverty, drugs, mental illness etc.) (Shor \& Friere, 1987), which are important factors of low achievements and sometimes even ESL. Nevertheless, what developing critical thinking can do is uncover these inequalities and discuss them from different points of view. In this way, educators already create an environment for a more inclusive, politically engaged and socially just curriculum, where all students can feel welcome, accepted and understood and where they feel safe to express their own views and become active creators of their educational path, lives and their society (McInerney, 2009), which are all conditions reducing the risk of ESL.

\section{References}

Alvermann, D. E., \& Hagood, M. C. (2000). Critical media literacy: Research, theory, and practice in 'New Times'. The Journal of Educational Research, 93 (3), 193-205. 
Bacolod, M., \& Hotz, V. J. (2006). Cohort changes in the transition from school to work: Evidence from three NLSY surveys. Economics of Education Review, 25, 351-373.

Boske, C., \& McCormack, S. (2011). Building an understanding of the role of media literacy for Latino/a high school students. The High Street Journal, $94(4), 167-186$.

Brown, J. A. (1998). Media literacy perspectives. Journal of Communication, 48 (1), 44-57.

Buckingham, D. (1998). Media education in the UK: Moving beyond protectionism. Journal of Communication, 48 (1), 33-43.

Buckingham, D. (2003). Media education: Literacy, learning and contemporary culture. Cambridge: Polity Press.

Choudhury, M., \& Share, J. (2012). Critical media literacy: A pedagogy for new literacies and urban youth. Voices from the Middle, 19 (4), 39-44.

Comber, B., \& Nixon, H. (2004). Children reread and rewrite their local neighbourhoods: Critical literacies and identity work. In J. Evans (Ed.), Literacy moves on: Using popular culture, new technologies and critical literacy in the primary classroom (115-133). London: Routledge.

Dewey, J. (1963). Experience and education. New York: Collier Books.

Duncan-Andrade, J. M. R., \& Morrell, E. (2007). Critical pedagogy and popular culture in an urban secondary English classroom. In P. McLaren \& J. L. Kincheloe (Eds.), Critical pedagogy: Where are we now (183-200). New York, NY: Peter Lang.

Dweck, C. S. (2000). Self theories: Their role in motivation, personality and development. Philadelphia: Psychology Press.

Erjavec, K. (2010). Medijska pismenost osnovnošolk in osnovnošolcev v informacijski družbi. Sodobna pedagogika, 2010 (1), 156-173.

Fiske, J. (1990). Introduction to communication studies ( $2^{\text {nd }}$ ed.). London: Routledge.

Garcia, E. E. (2005). Teaching and learning in two languages: Bilingualism and schooling in the United States. New York: Teachers College Press.

Gardiner, W. L. (1997). Can computers turn teaching inside-out, transform education, and redefine literacy? In R. Kubey (Ed.), Media literacy in the information age (359-376). New Brunswick: Transaction.

Guajardo, M., Guajardo, F., \& del Carmen Casaperalta, E. (2008). Transformative education: Chronicling a pedagogy for social change. Anthropology \& Education Quarterly, 39 (1), 3-22. 
Gunn, T. M., Chorney, D. W., \& Poulsen, J. C. (2009). High school completion: A comprehensive review of projects directed toward keeping students in school. Journal of At-Risk Issues, 15 (1), 17-24.

Hall, S. (1980). Encoding/decoding. In S. Hall, D. Hobson, A. Lowe \& P. Willis (Eds.), Culture, media, language (128-138). London: Hutchinson.

Halx, M. D. (2014). A more critical pedagogy: Could it reduce noncompleter rates of male Latino high school students? The student perspective. Pedagogy, Culture \& Society, 22 (2), 251-274.

Halx, M. D., \& Ortiz, M. (2011). Voices of Latino male high school students on the meaning of education: Perspectives of "drop-outs" and those-on-thebrink. Latino Studies, 9 (4), 416-438.

Hobbs, R. (1996). Media literacy, media activism. Telemedium, The Journal of Media Literacy, 42 (3), ii-iv.

Hobbs, R. (2001). The great debates circa 2001: The promise and the potential of media literacy. Community Media Review, 25-27.

Hull, G. A. (2003). At last: Youth culture and digital media: New literacies for new times. Research in the Teaching of English, 38 (2), 229-233.

Kanpol, B. (1994). Critical pedagogy: An introduction. Westport, CT: Bergin \& Garvey.

Kellner, D. (1995). Media Culture: Cultural studies, identity and politics between the modern and the postmodern. London: Routledge.

Kellner, D. (2004). Technological transformation, multiple literacies, and the re-visioning of education. E-learning, 1 (1), 9-37.

Kellner, D., \& Share, J. (2005). Information literacy: A positivist epistemiology and a politics of information. Educational Theory, 26 (3), 369-386.

Kellner, D., \& Share, J. (2007). Critical media literacy, democracy, and the reconstruction of education. Media literacy: A reader, 3-23.

Kincheloe, J. L. (2006). Introducing metropedagogy: Sorry, no short cuts in urban education. In J. L. Kincheloe, \& K. Hayes (Eds.), Metropedagogy: Power, justice and the urban classroom (1-39). Rotterdam: Sense Publishers.

Kincheloe, J. L. (2007). Critical pedagogy in the twenty-first century: Evolution for survival. In P. McLaren, \& J. L. Kincheloe (Eds.), Critical pedagogy: Where are we now (9-42). New York, NY: Peter Lang.

Kincheloe, J. L., \& McLaren, P. (1994). Rethinking critical theory and qualitative research. In N. Denzin, \& Y. Lincoln (Eds.), Handbook of qualitative research (138-157). Thousand Oaks, CA: Sage. 
Kozma, R. (1991). Learning with media. Review of Educational Research, 61 (2), 179-212.

Lewis, J., \& Jhally, S. (1998). The struggle over media literacy. Journal of Communication, 48 (1), 109-120.

Marin, L. M., \& Halpern, F. (2011). Pedagogy for developing critical thinking in adolescents: Explicit instruction produces greatest gains. Thinking Skills and Creativity, 6 (2011), 1-13.

Masterman, L. (1994). A rationale for media education: First part. In L. Masterman \& F. Mariet (Eds.), Media education in 199os' Europe (5-87). Strasbourg: Council of Europe.

McInerney, P. (2009). Toward a critical pedagogy of engagement for alienated youth: Insights from Freire and school-based research. Critical Studies in Education, 50 (1), 23-35.

Meyrowitz, J. (1998). Multiple media literacies. Journal of Communication, 48 (1), 96-108.

Perez Tornero, J. M., \& Varis, T. (2010). Media literacy and new humanism. Moscow: UNESCO Institute for Information Technologies in Education.

Rubin, A. M. (1998). Media literacy. Journal of Communication, 48 (1), 3-4.

Schofield, A., \& Rogers, T. (2004). At play in fields of ideas. Journal of Adolescent \& Adult Literacy, 48 (3), 238-248.

Shor, I., \& Freire, P. (1987). Critical teaching and everyday life. Chicago: University of Chicago Press.

Shor, I. (1992). Empowering education: Critical teaching for social change. Chicago, IL: University of Chicago Press.

Silverblatt, A. (1995). Media literacy: Keys to interpreting media messages. Westport: Praeger.

Singer, D. G., \& Singer, J. L. (1998). Developing critical viewing skills and media literacy in children. The Annals of the American Academy of Political and Social Sciences, 557, 164-180.

Steinberg, S. R., \& Kincheloe, J. L. (1998). Students as researchers: Creating classrooms that matter. Bristol: Falmer Press.

Stringfield, S., \& Land, D. (2002). Educating at-risk students. Chicago, IL: National Society for the Study of Education.

Taghva, F., Rezaze, N., Ghaderi, J., \& Taghva, R. (2014). Studying the relationship between critical thinking skills and students' educational achievement (Eghlid Universities as case study). International Letters of Social and Humanistic Sciences, 25, 18-25. 
Thoman, E., \& Jolls, T. (2004). Media literacy-A national priority for a changing world. American Behavioral Scientist, 48 (1), 18-29.

Valenzuela, A. (2005). Leaving Texas children behind: How Texas style accountability fails Latino youth. New York: State University of New York Press. 
2.4 understanding the problem and consequences of ESL 



\subsection{I}

\section{Why is ESL a Problem for Contemporary (EU) Society?}

Urška Štremfel and Klaudija Šterman Ivančič

\section{Synopsis}

EU policy documents stress that ESL holds important long-term economic consequences (economic growth) and macro-social consequences (social cohesion). Research calculating the financial costs of ESL very convincingly supports these arguments, while there are various difficulties in quantifying the social consequences of ESL. According to critical policy approaches, this potentially narrows understanding of the problem of ESL to its economic dimension.

\section{Summary}

ESL is commonly regarded as an urgent and serious problem for both individuals and EU society as a whole. Taking different classifications into consideration, the article focuses on the medium- and long-term fiscal (economic) and social consequences of ESL. It reviews various economic studies presenting ESL as a huge obstacle to further national and EU economic growth. These studies are chiefly based on a calculation of the estimated costs (including lower tax revenues and/or higher unemployment and welfare payments and/or higher public health expenditures and/or higher police expenditures and/or higher criminal justice expenditure) per individual ESLer lifetime and range from EUR 100,00o to EUR 1 million. Studies presenting aggregate financial gains expected from reducing ESL are also referred to. In addition, the weaknesses of the methodologies 
used in those studies are identified (e.g. difficulties in scenario-making due to high complexity and the rapidly changing environment; the issue of fully identifying education's causal impact on various outcomes; the lack of data for estimating both the market-recognised and social costs of ESL), which to some extent question the credibility of their results. Since it is very hard or even impossible to monetise the social effects of ESL, the article exposes this makes them less convincing policy arguments than the economic costs of ESL. Critical policy approaches (wicked problems, governance of problems, problems represented to be) are introduced, showing that policy problems are not neutral but political and social constructs, thereby questioning the dominant (economic) understanding of the ESL problem. Within this framework, the article concludes that investments made in reducing ESL should not be only valued in terms of significant long-term financial savings, but that an essential component of its equally important, albeit in research less convincing, and visible contribution to a socially-cohesive EU society should also be taken into account.

Key words: ESL, problem, social consequences, economic consequences, EU

\section{Introduction}

Early school leaving in the EU is recognised as being a complex educational, economic and social problem (e.g. Council of the EU, 2011; 2015). The question of what defines ESL as a problem is crucial given that problem structuring is seen as the most critical task in the development of any policy (Dunn, 1981). Therefore, much attention in EU policy documents as well as in research is paid to demonstrating the problems (negative consequences/impacts/effects/costs) ESL brings to individuals, societies, nation-states and the EU as a whole. This level of attention helps EU member states identify and understand problems with education and training at the national level (Ecorys, 2014) and provide a key rationale for tackling ESL among all relevant actors (Ross \& Leathwood, 2013).

Typcially, the literature addresses ESL by considering the costs ESL brings to different individual and collective entities (Belfield, 2008; Brunello \& De Paola, 2013; Psacharopoulos, 2007). In that framework, Psacharopoulos (2007) distinguishes the following costs brought about by ESL: private (realised by the individual and mostly directly observed in 
the market); social (impact on society as a whole and not directly observable); fiscal (taking the form of foregone benefits). Noting that the costs of ESL typically last the course of an individual's lifetime, Dale (2010) and the European Commission (n.d.) explain how these categories may also be understood as the short-term (private costs), medium-term (social and economic costs in the form of lower income, reduced tax revenues and higher costs of public services related, for example, to healthcare, criminal justice and social benefit payments, leading to low economic growth) and longterm consequences of ESL (social and economic development). These discussions closely correspond with discussions on the role of education in contemporary EU society where quality education is defined as a prerequisite for social cohesion and economic growth (Lisbon Strategy) and smart, sustainable and inclusive growth (Europe 2020 Strategy).

Apart from the economic studies that prevail in this area, several other research studies come into play, ranging from sociology to medicine, political and to a limited extent educational science. Hankivsky (2008) explained that, as case studies of such research, the literature is dominated by the USA (e.g. Belfield \& Levin, 2007; Chaplin \& Lermar, 1997; Cohen, 1998) and to some extent Australia (e.g. Business Council of Australia, 2003; Lamb, Dwyer, \& Wynn, 200o) and Canada (e.g. Human Resource Development of Canada, 2000) and that European countries have more or less been absent. Almost a decade after Hankivsky's review, some studies presenting the consequences of ESL for particular member states and the EU as a whole can be identified (for a review, see Brunello \& De Paola, 2013; European Commission, n.d.), yet those from the USA (e.g. Catterall, 2011; Sum, Khatiwada, \& McLaughlin, 2009), Australia (e.g. Deloitte, 2012; Lamb \& Huo, 2017) and Canada (e.g. Canadian Council on Learning, 2009) continue to prevail. Since ESL is a social phenomenon, also highly influenced by system-level factors, the article elaborates on the consequences of ESL in the EU context. It looks at other countries only to a limited extent in order to make some comparisons or provide valuable data that is missing in the EU setting.

Since the private and social costs of ESL are already addressed in the TITA scientific base from the standpoint of the individual ESLer, this contribution focuses on the medium- and long-term social and fiscal (economic) consequences of ESL. 'As such, it addresses the question "Why is ESL a

Psacharopoulos (2007) explains there is also a considerable overlap among the (private, social and fiscal) consequences of ESL. For example, a low level of education 
problem for contemporary (EU) society?". After introducing the topic, the article first presents the economic (fiscal) consequences of ESL, second, the social consequences are described, third, different unresolved questions of researching and understanding ESL as a problem of economic and social development are mentioned, while the conclusion summarises the main findings.

\section{Methodology}

This article draws on a review of theoretical and empirical evidence. To address the article's aims, we apply the following methods: (a) an analysis of relevant literature and secondary sources. Here we conducted a literature search of the scientific EBSCOhost, Web of Science and Google Scholar online research databases. The main key words used in searching the relevant scientific literature were: early school leaving, consequences, impact, effect, social cohesion, social development, economic growth, economic competitiveness, economic development; and (b) an analysis of EU-level formal documents and legal sources (Council Resolutions, European Commission Communications, Reports of Expert Networks).

\section{ESL as an obstacle to economic development}

Discussions on the economic consequences of ESL arise from general discussions on the importance of education (e.g. quality and attainment levels of individuals) for economic development (e.g. Hanushek \& Wößmann, 2010; OECD 2010). For example, it is estimated that in the OECD countries each year of schooling is statistically significantly associated with a $0.30 \%$ higher rate of economic growth (Psacharopoulos, 2007).

Studies concentrating on the economic consequences of ESL are mostly based on a calculation of the estimated costs (including lower tax revenues and/or higher unemployment and welfare payments and/or higher public health expenditures and/or higher police expenditures and/or higher criminal justice expenditure) per individual ESLer lifetime and by calculating the returns of an additional year of schooling. Taking into consideration the number of ESLers and the differences between the target (ESLers) and non-target group (non-ESLers), studies then calculate the aggregate

can limit employment opportunities and the earnings potential of ESLers, thereby leading to lower income tax payments and an increased risk of needing social benefits and participating in different welfare programmes (European Commission, n.d.). 
Table 3. Review of studies presenting financial gains expected from the reduction of ESL

\section{Country Total cost of ESL to the country}

Explanation

If ESL could be cut in half for one age cohort, the country would gain about

Estonia $\quad 0.7 \%$ of GDP, equalling EUR $113.8 \mathrm{mil}-$ lion using a $3 \%$ discount rate, or about $0.35 \%$ of GDP, equalling EUR 56.6 million using a $6 \%$ discount rate

Increasing the education level of Roma children from having at most prima-

Hungary ry-level education to an upper secondary qualification would see a gain of income of some EUR 30,000 - 70,000 per person for the state

Savings from reducing ESL for 15,000

Netherlands individuals made over a 5-year period could reach nearly EUR 3.7 billion in total

The figures refer to the cost of ESL

If the ESL rate could be cut by one-third, the total costs for society would be reduced by NOK 5.4 billion (around EUR 723 million) per age cohort.

Norway The top estimate of the reduced societal costs is NOK 8.8 billion (around

The gains consist of taxes after income and consumption, and social security payments. They exclude costs related to unemployment and offending.

$38 \%$ deriving from additional taxations, $12 \%$ from reduced subsidies, $1.4 \%$ from less criminal activity, $0.5 \%$ from better health EUR 1.2 billion), while the lower bound is NOK 1.1 billion (around EUR 146 million)

By reducing ESL, an increase in GDP of $4 \%$ to $17 \%$ could be achieved over a 20-year time horizon.

Effects on employment and wages by eradicating ESL are taken into account.

Estimates of the public finance cost of young people who are NEET vary from GBP 12 billion to GBP 32.5 billion Resource costs associated with NEET range from just under GBP 22 billion

United Kingdom to nearly GBP 77 billion

In the UK, if $1 \%$ more of the working population had A-levels rather than no qualifications, the benefit to the UK would be around GBP 665 million a year through reduced crime and increased earnings potential

The figures refer to ESLers and exclude crime and health-related costs

All the UK figures relate to the cost of being NEET (young people not in employment, education or training, aged 16 and 18)

Sources: Calero \& Gil-Izquierdo (2014); European Commission (n.d.); Nevala \& Hawley (2OII) 
costs of ESL at the national/EU level and/or financial gains expected from reducing ESL at the national/EU level (Nevala \& Hawley, 2011; European Commission, n.d.).

The estimated costs of an ESLer per lifetime differ widely among the EU member states and studies conducted. Brunello and De Paola (2014) report they range from EUR 33,000 in Ireland to about GBP 56,000 in the UK, from EUR 120,000 in Norway to EUR 157,000 in Estonia. Somewhat different amounts are reported by the European Commission (n.d.), showing that the lifetime costs of an ESLer range from EUR 100,000 through EUR 200,000 up to EUR 1.1 million. A review of studies that estimated the total cost of ESL and financial gains expected from reducing ESL in some European countries is presented in Table 1.

Due to the different research methodologies used in estimating costs, the range of costs included in the calculations, and differences in national contexts in which studies have been conducted, it is very difficult to make comparisons (Beirn, 1972; European Commission, 2013, n.d.; Van Alphen, 2009).

Among the various national studies, some studies also estimated the costs of ESL for the EU economy as a whole. More than a decade ago, basing the calculation on the assumption that ESLers have 6\% lower productivity than qualified leavers, and using the 2005 figure of $23 \%$ unqualified leavers, suggested that ESL causes the European economy a productivity loss of 1.4\% (European Commission, 2006). The European Commission (n.d.), using Eurofound calculations, shows that the annual cost of NEETs to the 21 EU member states (DK, EL, FI, FR, MT, SE, CRO not involved) is approximately EUR 100 billion (EUR 94 billion in foregone earnings and EUR 7 billion in excess transfers), which corresponds to $1 \%$ of their aggregated GDP. Considering the Europe 2020 flagship initiative 'An agenda for new skills and jobs', the European Commission (2011) estimates that "To reduce the average European ESL rate by just 1 percentage point would provide the European economy each year with nearly half a million additional qualified potential young employees". Reflecting the estimation that the share of jobs available to low skilled people will drop in the near future from $20 \%$ to less than $15 \%$, it is predicted that the economic consequences of ESL in the EU will become even worse. Despite numerous projections, the European Commission (2013) argues that so far it has been difficult to accurately estimate the costs of ESL at the EU level. 
Only a few studies in Europe have evaluated anti-ESL measures with regard to their cost efficiency (relationship between the cost of an anti-ESL measure and the estimated benefit of reducing ESL). ${ }^{2}$ Existing studies indicate that policies differ in their efficiency, but also that measures have varying impacts on different groups of pupils and in different contexts. Despite their methodological limitations (e.g. the long-term effect of policies is often insufficiently factored in), their results allow the conclusion that the total costs for society created by ESL far exceed the costs of most measures aiming to reduce ESL (European Commission, 2011; 2013; Nevala \& Hawley et al., 2001, p. 51).

The studies overviewed above show that the economic consequences of ESL demonstrated as costs of ESL present a huge obstacle to further national and EU economic growth, and vice versa that countries can achieve high total gains from cutting ESL. Accompanied by cost-benefit studies of various interventions already implemented, this underscores the claim that policies addressing ESL continue to be needed and represent a worthwhile investment in the EU's economic development.

Despite these very convincing research results, deficiencies in their methodologies (cost-benefit, scenario-making, policy and social experimentations) used to estimate the costs of ESL have been identified, which somewhat question the credibility of their results (Brunello \& De Paolla, 2013; European Commission, 2013; Green et al., 2004; Hankivsky, 2008; Psacharopoulos, 2007):

- difficulties in scenario-making due to high complexity and the rapidly changing environment of contemporary society and economy (problems with estimating the medium- and long-term consequences of ESL; predicting and including particular costs in calculations);

- the issue of fully identifying the causal impact of education on various outcomes (observable and unobservable characteristics of ESLers and the control group on which the benefits of ESL policies are evaluated);

- $\quad$ the lack of data (a major difficulty in identifying education externalities is that the output, as typically measured in national

2 For example, Levin (2009) demonstrated that delivering successful preventive programmes in the area of completing upper secondary education in the USA brings benefits (USD 209,000) that are up to 2.5 times greater than the cost of intervening per graduate (between USD 59,000 and USD 143,600). 
accounts, only includes market-recognised effects of education and not other costs (e.g. social costs impacting society as a whole and not directly observable).

\section{ESL as an obstacle to social development}

The social benefits of education (social cohesion, social inclusion) lie at the heart of the EU's (Lisbon, EU 2020) policy agenda. The Council of Europe (2008) defines social cohesion as "the capacity of a society to ensure the well-being of all its members, minimising disparities and avoiding marginalisation". Similarly, the OECD (2011) calls a society "'cohesive' if it works towards the well-being of all its members, fights exclusion and marginalisation, creates a sense of belonging, promotes trust, and offers its members the opportunity of upward social mobility".

While various academic studies have discussed the microsocial benefits of education (social and civic engagement), a sense of belonging, trust, equality, inclusion and mobility of individual students), the macrosocial benefits (social development, social cohesion of nation-states, the EU) have been studied to a limited extent. Green, Preston and Sabates (2003) argue that, due to their conceptual differences (level and emphasis on the relational properties and social functioning), the macrosocial benefits of education cannot be simply understood as the aggregation of microsocial benefits. This fact may at least partly explain the high complexity of the macrosocial benefits of education (e.g. social cohesion) and the absence of clarity on what they actually encompass and how education may affect them.

Green et al. (2004) argue that great variations in definitions and various meanings within/between national contexts additionally make researching the relationship between education and social cohesion an extremely difficult task. ${ }^{3}$ They (2004, p. 124) add that work relating to the influence of education on social cohesion is often qualitative in nature and that it is difficult to operationalise and test hypotheses related to learning and social cohesion within a positivist framework. The OECD (2006) notes that, while human capital theory links education to economic outcomes and offers a robust framework for scientific investigation and policy analysis, there is to date no widely accepted theory linking education to social outcomes which could at least partly explain the lack of research in this area (Fernandez Gutierrez \& Calero Martinez, 2014). 
Hankivsky (2008) discusses the social consequences of ESL in terms of intangible costs and non-market effects of ESL. She argues that, although these aspects are crucial for further social development, they are very difficult to quantify. In any case, based on her research she made the assumption that intangible (social) costs are equal to $50 \%$ of all tangible (economic) costs of ESL. It has also been estimated that the intangible costs far surpass all other direct and indirect costs of ESL combined.

Psacharopoulos (2007, p. 29) argues that since it is very hard or even impossible to monetise the social effects of ESL, this makes them less convincing policy arguments than the economic costs of ESL. These observations coincide with some other warnings that areas that are more easily measurable attract more (policy) attention than more difficult-to-measure areas. In doing so, there is a fear that areas that do not directly contribute to performativity are in danger of becoming worthless (Ball, 2003; Ozga, 2003).

ESL holds important long-term social consequences in terms of social cohesion and the development of nation-states and the EU. Although they are very hard (if not impossible) to quantify and measure, they should not be overlooked when designing, implementing and evaluating policy measures against ESL.

\section{Challenges in understanding the problem of ESL}

Several critical approaches have been developed in policy analysis that challenge the positivist understanding of policy problems as a neutral category. They claim that policy problems are not neutral but represent social constructions and that policy problems do not pre-exist but are actively created and produced. The literature review shows that the ESL problem can also be understood in that framework.

\section{Wicked problems}

Haug and Plant (2015) and Smyth (2010) denote ESL as a wicked problem (Rittel \& Webber, 1973). Smyth (2010, p. 198) citing the Australian Public Service Commissioner summarised wicked problems as being »difficult to define ... have many interdependencies (that) are often multi-causal ... often lead to unforeseen consequences ... not stable ... have no clear solutions ... are socially complex ... hardly ever sit conveniently within the responsibility of any one organization ... (and) involve changing behaviour«. 
Although arguments exist that wicked problems are difficult or impossible to solve, Roberts (2000) pointed out three possible strategies to cope with them: authoritative, competitive and collaborative. Constraints of the last two open a space for the first one and enable a (specific and narrow) solution to be formed and thus understanding of the problem.

\section{Governance of problems}

Problem processing actually starts by searching for problems: governing depends on identifying situations as problematic, acknowledging the expertise in connection with these problems and discovering governing technologies that are considered to be a suitable response (Colebatch 2006, 313). Collective problem-solving means people have common values and jointly identified policy goals (or a desired future situation) (Hoppe, 2011). Grek (2010) argues that international institutions and organisations (European Commission and OECD) are crucial in the construction of specific policy problems in the EU and thus the promotion of particular dispositions to learning (therefore also to ESL) in member states. The process of problematisation is thus the prevailing form of setting new education policy agendas in Europe. Since the very process of problem creation already carries the seed of its solution, a critical approach should be applied when studying problems that are placed high up the EU policy agenda.

\section{Problem represented to be}

Oomen and Plant (2014) assert that the ESL problem could be studied through Bacchi's (2009) WPR (What's the Problem Represented to be?) approach. The WPR approach starts from the premise that what policy actors propose to do about something reveals what they think is problematic (needs to change). Following this thinking, policies and policy proposals contain implicit representations of what is considered to be the 'problem' ('problem representations'). For example, if educators' training is recommended to reduce ESL, the implication is that the lack of educators' competencies is the problem (a factor that causes ESL). Many other potential factors (e.g. at the individual or system level) are then left behind. By applying the WPR approach, Bacchi suggests asking six questions ${ }^{4}$ in order to subject every problem presentation to critical scrutiny.

4 1) What's the 'problem' /.../ represented to be in a specific policy or policy proposal? 2) What presuppositions or assumptions underpin this representation of the 'problem'? 3) How has this representation of the 'problem' come about? 4) What is 
When taking the critical representations of policy problems formation presented above into consideration, it is important to see how the social and economic consequences of ESL are presented as a rationale for understanding ESL as a problem for contemporary (EU) society. Gillies \& Mifsud (2016) from a Foucauldian perspective, Grimaldi (2012) by analysing neoliberalism influences and Macedo, Araújo, Magalhães and Rocha (2015) through the lenses of sociology of education define ESL as a political concept, pursuing a specific solution by providing a specific (economic) vision of the problem and their prevalence over social goals.' Similarly, Ross and Leathwood (2013, p. 415) refer to the need to evaluate the success of ESL measures according to their contribution to addressing social exclusion, division and inequalities and not solely how they contribute to the overall economic prosperity of society, as is the existing practice.

\section{Conclusion}

The perception of ESL holding negative consequences for individuals and society and bringing positive benefits via increased educational attainment sensitises and induces policymakers to design policies in an attempt to take corrective action and address the ESL problem (Brunello \& De Paola, 2013; Psacharopoulos, 2007).

The paper overviewed a broad range of academic research and EU policy documents discussing the long-term macro-economic and macro-social consequences of ESL (economic growth and development, social cohesion and development). The overview shows that in identifying education externalities, the output, typically measured in national accounts, most commonly includes economic (market-recognised) effects of education since it is hard or even impossible to quantify the social effects (Psacharopoulos, 2007). ESL is thus generally presented as huge obstacle to further national

left unproblematic in this problem representation? Where are the silences? Can the 'problem' be thought about differently? 5) What effects are produced by this representation of the 'problem'? 6) How/where has this representation of the 'problem' been produced, disseminated and defended? How has it been (or could it be) questioned, disrupted and replaced?

5 The inferior position of the social dimension of education in general is also evident from selected OECD and EU policy documents. The OECD (2011, p. 58) claims that social inclusion is both a desirable end in itself and a means to achieve development outcomes like growth, and question whether social cohesion, beyond its intrinsic desirability, actually has a use, e.g. an economic pay-off. The European Commission (2006) explains that investing in education and training in order to raise efficiency and quality produces social benefits which, in turn, feed economic growth. 
and/or EU economic growth in terms of the costs of an individual ESLer per lifetime and the financial gains of potentially reducing ESL. According to critical approaches of understanding policy problems (wicked problems, governance of problems, problem represented to be) that were also presented in the paper, this creates the possibility that the social benefits of education and thus the social negative consequences of ESL will become overlooked when designing measures against ESL and opens the question of whether studies that point out the financial costs are not being used to justify a distinct (economically oriented) policy regarding ESL in the EU.

\section{References}

Bacchi, C. (2009). Analysing Policy: What's the Problem Represented to Be? Frenchs Forest, New South Wales: Pearson Education.

Ball, J. S. (2003). The teacher's soul and the terrors of performativity. Journal of Education Policy, 18(2), 215-228.

Beirn, R. (1972). Antecedents and consequences of early school leaving. Geneva: International Bureau of Education.

Belfield, C. R., \& Levin, H. M. (Eds.). (2007). The price we pay: Economic and social consequences of inadequate education. Washington, DC: Brookings Institution Press.

Belfield, C. (2008). The cost of early school-leaving and school failure. Research prepared for the World Bank. New York: Queens College, City University of New York.

Brunello, G. \& De Paola, M. (2013). The costs of early school leaving in Europe. EENEE Analytical Report No. 17. Brussels: European Commission.

Business Council of Australia (2003). The cost of dropping out: The economic impact of early school leaving. Dusseldorf Skills Forum and Applied Economics.

Calero, J. \& Gil-Izquierdo, M. (2014). Too much to pay: An estimation through microsimulation techniques of the monetary costs of early school leaving in Spain. Journal of Simulation, 8(4), 314-324.

Canadian Council on Learning (2009). No "drop" in the bucket: The high costs of dropping out. Retrieved from http:/en.copian.ca/library/research/ ccl/lessons_learning/no_drop_bucket/no_drop_bucket.pdf

Catterall, J. C. (2011). The societal benefits and costs of school dropout recovery. Education Research International. 
Chaplin, D., \& Lerman, B. (1997). Dropping out: Public and private costs. Washington: The Urban Institute.

Cohen, M. (1998). The monetary value of saving a high-risk youth. Journal of Quantitative Criminology, 14(1), 5.

Colebatch, K. Hall. (2006). What work makes policy? Policy Sciences, 39(4), 309-321.

Council of Europe (2008). Report of high-level task force on social cohesion. Towards an active, fair and socially cohesive Europe. Strasbourg: Council of Europe.

Council of the EU (2011). Council Recommendation on policies to reduce early school leaving. Retrieved from http://eur-lex.europa.eu/legal-content/ $\mathrm{EN} / \mathrm{TXT} / \mathrm{PDF} /$ ?uri=CELEX:32011Ho701(01)\&from $=\mathrm{EN}$

Council of the EU (2015). Council conclusions on reducing early school leaving and promoting success in school. Retrieved from http://eur-lex.europa.eu/ legal-content/EN/TXT/PDF/?uri=CELEX:52015XG1215(O3)\&from=EN

Dale, R. (2010). Early school leaving, lessons from research for policy makers, NESSE Report. Brussels: European Commission.

Deloitte (2012). The socio-economic benefits of investing in the prevention of early school leaving. Retrieved from http://handsonlearning.org.au/DAE_investing_in_preventing_ESL_via_HOL_September_2012.pdf

Dunn, W. N. (1981). Public policy analysis. Englewood Cliffs, NJ: Prentice-Hall. Ecorys (2014). Interim evaluation of the strategic framework for European cooperation in education and training (ET 2020). Retrieved from http:// ec.europa.eu/dgs/education_culture/more_info/evaluations/docs/ education/et2020_en.pdf

European Commission (2006). Communication from the Commission to the Council and to the European Parliament: Efficiency and Equity in European Education and Training systems. Brussels: European Commission.

European Commission (2011). Early school leaving in Europe - questions and answers. Retrieved from http://europa.eu/rapid/ press-release_MEMO-11-52_en.htm

European Commission (2013). Reducing early school leaving: Key messages and policy support. Final Report of the Thematic Working Group on Early School Leaving. Retrieved from http:/ec.europa.eu/education/ policy/strategic-framework/doc/esl-group-report_en.pdf

European Commission (n.d.). Overview and examples of costs of early school leaving in Europe. Retrieved from http://ec.europa.eu/dgs/ 
education_culture/repository/education/policy/strategic-framework/doc/ europe-esl-costs_en.pdf

Fernandez Gutierrez, M., \& Calero Martinez, J. (2014). The non-monetary costs of early school leaving: Estimation in terms of years of good health. Educacion, 17(2), 241-263.

Gillies, D. \& Mifsud, D. (2016). Policy in transition: The emergence of tackling early school leaving (ESL) as EU policy priority. Journal of Education Policy, 31(6), 819-832.

Green, A., Preston, J., \& Malmberg, L. E. (2004). Non-material benefits of education, training and skills at a macro level. In P. Descy and M. Tessaring (eds.), Impact of education and training. Third report on vocational training research in Europe: background report (pp. 119-177). Luxembourg: Office for Official Publications of the European Communities.

Green, A., Preston, J., \& Sabates, R. (2003). Education, equality and social cohesion: A distributional approach. Compare, 33, 453-470.

Grek, S. (2010). International organisations and the shared construction of policy 'problems': problematisation and change in education governance in Europe. European Educational Research Journal, 9(3), 396-406.

Grimaldi, E. (2012). Neoliberalism and the marginalisation of social justice: The making of an education policy to combat social exclusion. International Journal of Inclusive Education, 16(11), 1131-1154.

Hankivsky, O. (2008). Cost estimates of dropping out of high school in Canada. Retrieved from http://200.6.99.248/ bru $487 \mathrm{cl} /$ files/Costofdroppingout.pdf

Hanushek, E. A., \& Wößmann, L. (2010). Education and economic growth. In P. Peterson, E. Baker, \& B. McGaw (Eds.). International Encyclopedia of Education (pp. 245-252). Oxford: Elsevier.

Haug, E. H. \& Plant, P. (2015). The potential role of career guidance and career education in combating early school leaving. Neveléstudomány, 3, 5-15.

Hoppe, R. (2011). The governance of problems: Puzzling, powering and participation. Bristol: The Policy Press.

Human Resources Development Canada. (200o). Dropping out of High School: Definitions and Costs. Ottawa: Applied Research Branch, Strategic Policy. R-01-1E. October, 200o. Retrieved from http://www11.hrsdc.gc.ca/en/cs/ $\mathrm{sp} / \mathrm{hrsdc} / \mathrm{arb} / \mathrm{publications} /$ research/2000-00oo63/pageog.shtml

Lamb, S., Dwyer, P., \& Wynn, J. (200o). Noncompletion of school in Australia: The changing patterns of participation and outcomes. Camberwell, Victoria: ACER. 
Lamb, S., \& Huo, S. (2017). Counting the costs of lost opportunity in Australian education. Mitchell Institute report No. 02/2017. Melbourne: Mitchell Institute.

Levin, H. M. (2009). The economic payoff to investing in educational justice. Educational Researcher, 38, 5-20.

Macedo, E. Helena C. Araújo, H. C., Magalhães, A. \& Rocha, C. (2015). The construction of early school leaving as a political concept under the lenses of sociology of education. Profesorado, 19(3), 28-42.

Nevala, A. M., \& Hawley, J. et al. (2011). Reducing early school leaving in the EU. Study. Brussels: European Parliament.

OECD (2006). Measuring the Effects of Education on Health and Civic Engagement. Proceedings of the Copenhagen Symposium. Retrieved from https://www.oecd.org/edu/innovation-education/37437718.pdf

OECD (2010). The high cost of low educational performance. The long-run economic impact of improving PISA outcomes. Paris: OECD Publishing.

OECD (2011). Perspectives on global development 2012 social cohesion in a shifting world. Paris: OECD Publishing.

Oomen, A., \& Plant, P. (2014). Early school leaving \& lifelong guidance. ELGPN Concept Note No. 6. Jyväskylä: European Lifelong Guidance Policy Network.

Ozga, J. (2003). Measuring and managing performance in education. Edinburgh: University of Edinburgh: Centre for Educational Sociology (CES) Briefing No. 27.

Psacharopoulos, G. (2007). The costs of school failure - a feasibility study. European Expert Network on Economics of Education.

Rittel, H. J., \& Webber, M. M. (1973). Dilemmas in the general theory of planning. Policy Science, 4, 155-169.

Roberts, N. C. (2000). Wicked problems and network approaches to resolution. International Public Management Review, 1(1), 1-19.

Ross, A., \& Leathwood, C. (2013). Problematising early school leaving. European Journal of Education, 48(3), 405-418.

Smyth, J. (2010). Adolescent engagement, connectedness and dropping out of school. In J. L. DeVitis, \& L. Irwin-DeVitis (Eds.), Adolescent education. $A$ reader (pp. 195-208). New York: Peter Lang.

Sum, A., Khatiwada, I., \& McLaughlin, J. (2009). The consequences of dropping out of high school: Joblessness and jailing for high school dropouts and 
the high cost for taxpayers. Center for Labor Market Studieublications. Paper 23. NorthEastern University.

Van Alphen, S. (2009) The educational quality of early school leavers and the cross-national variation of their income disadvantage. Educational Research and Evaluation: An International Journal on Theory and Practice, 15(6), 543-560. 


\section{4 .2}

\section{Early School Leavers in their Later (Adult) Life and Social Consequences}

Klaudija Šterman Ivančič

\section{Synopsis}

ESL holds many far-reaching effects for an individual's overall quality of life: lower employability, income and savings, inferior (public) health status, less risk aversion and increased criminality, less supportive social capital, and reduced lifetime satisfaction. To successfully tackle ESL, it is therefore crucial for all actors involved to be aware of the consequences and help combat ESL on time.

\section{Summary}

This article explains the long-term effects of ESL on different aspects of an individual's personal and social life. In defining the consequences of ESL, we start by examining Psacharopoulos' (2007) framework of ESL consequences and cost estimation, where the author refers to the private, social and fiscal impacts of ESL. Since here we are mainly interested in those consequences with the greatest impact on an individual's personal life (personal consequences) and the individual's social functioning (social consequences), in the article we describe: a) private far-reaching consequences that, according to the author, refer to a higher incidence and duration of unemployment, lower initial and lifetime earnings, inferior health status (e.g. risk of psychological and somatic health problems), less risk aversion (e.g. drug use, criminal behaviour), reduced lifelong-learning participation, a lower quality of social capital (poorer and unsupportive 
social ties) and lower overall lifetime satisfaction; and b) social consequences that refer to increased criminality, lower positive spill-over effect of co-workers, lower positive intergenerational effects and inferior public health assistance access. A review of different studies that discussed these far-reaching private and social consequences of ESL (e.g. Crum et al., 1998; Hawkins et al., 1992; Henry et al., 1999; Jarjoura, 1993; Lamb, 1994; Silbereisen et al., 1995) on an individual's overall well-being throughout their life confirmed these effects. We conclude it is therefore vital for different actors to be aware of the long-term consequences of ESL and that timely systematic intervention and compensation practices are essential. As part of this, it is very important to be aware of the individual's reasons for ESL since in this way we can identify whether ESLers are more likely to form a new stable identity or are at a greater risk of developing and intensifying maladaptive behaviours.

Key words: early school leaving, later life, private consequences, social consequences

\section{Introduction}

While addressing the consequences of ESL in adult life we encounter different conceptions of the importance of a certain type of consequence. In Europe, one of the most often addressed is certainly the unemployment of ESLers since it has the most evident impact on both the labour market and economic growth (Alphen, 2009). However, the consequences of ESL for individuals are much wider and more far-reaching.

In an effort to minimise ESL rates, several attempts by different policymakers (e.g. EENEE, 2013) have been made to estimate the costs of ESL on different levels. The basis most commonly used in the literature for estimating such costs is Psacharopoulos' (2007) framework for estimating the costs of ESL that addresses various areas of ESL consequences. The author defines the outcomes of ESL on three levels: private, social and fiscal (see Figure 16). On the private level, the author lists the higher incidence and duration of unemployment, lower initial and lifetime earnings, inferior health status, less risk aversion, reduced lifelong-learning participation, a lower quality of social capital and lower lifetime satisfaction. On the social level, he points to increased criminality, lower positive spill-over effects of co-workers, a lower rate of economic growth, lower intergenerational effects on children and parents, inferior public health assistance 
access, higher unemployment rates and lower social cohesion. On the fiscal level, he sees the most evident effects of ESL in lower tax revenues, higher unemployment and welfare payments, higher public health expenditures, increased police expenditures and higher criminal justice expenditure. Psacharopoulos (2007) also states there are direct and indirect effects between the duration of education and different aspects of consequences. For example, the direct effect of education on a health outcome is better awareness among the more educated of the harmful effects of smoking. Indirect effects arise when, for an example, a worker's income supports his ability to pay for high quality health services, which leads to a reduced burden of disease on society (European Commission, 2010 and 2013). Since Psacharopoulos' ESL consequences framework is one of the most widely used, including by the European Commission, we also employ it for its definition of the consequences of ESL on which our further descriptions are based.

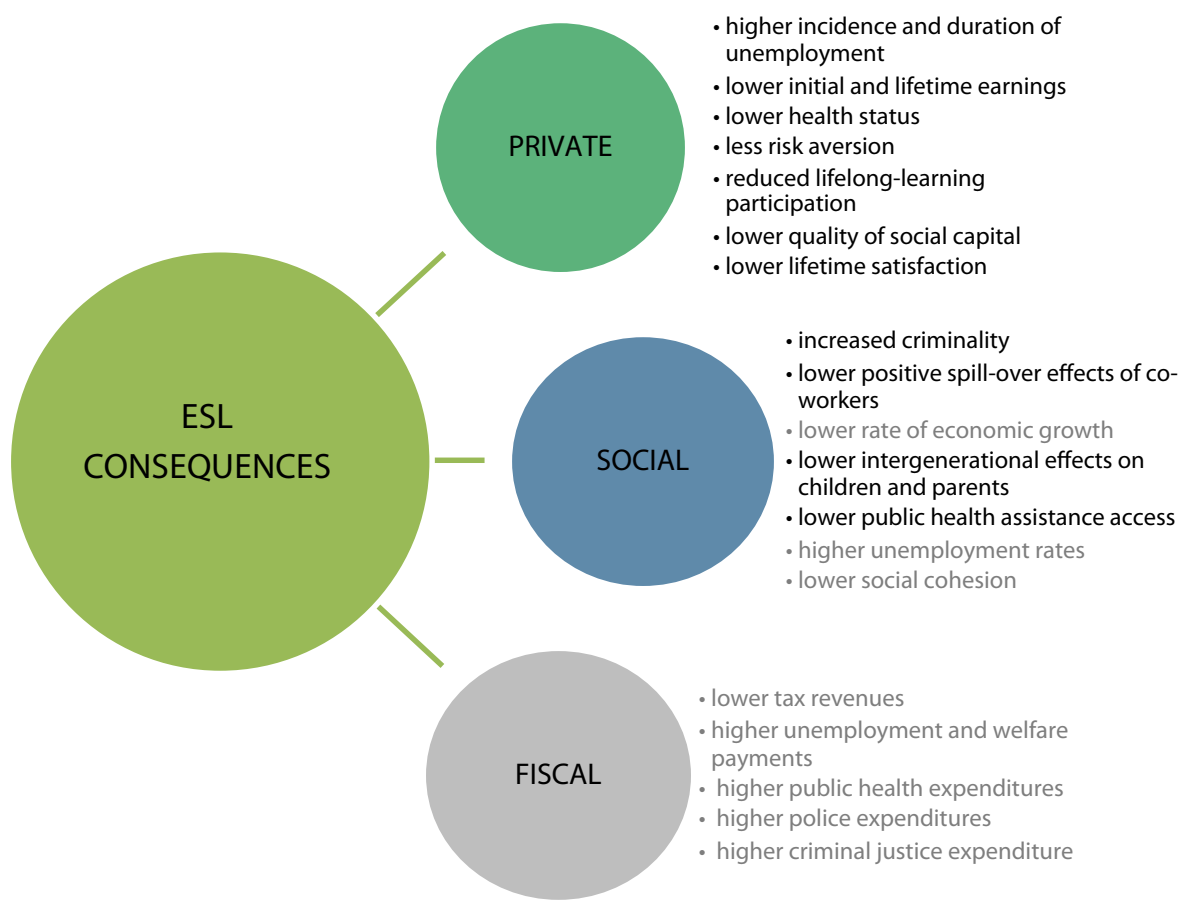

Figure 16. Consequences of ESL (as defined by Psacharopoulos (2007)) 
The present article has two aims. The first is to focus on and describe the consequences of ESL that affect an individual on the private and social levels. Such ESL consequences have the biggest impact on an individual's life, and his/her social functioning. At this point, we will not focus on the fiscal consequences of ESL and certain aspects of social consequences with a more widespread, societal impact (e.g. a lower rate of economic growth, higher unemployment rates and lower social cohesion). The consequences that will not be addressed in this article are coloured in grey in Figure 16. Since we are examining social consequences from the individual's perspective, i.e. the effects ESL has on an individual's social life and closer surroundings, some private and social consequences are linked to the same area of an individual's life (e.g. less risk aversion and increased criminality). Accordingly, we combined private and social consequences with a similar content. The article's second aim is to draw attention to the fact that ESL has a long-reaching effect that greatly impacts an individual's quality of life in different areas and to point out it is important to raise awareness of the consequences it can bring in order to prevent it on time.

\section{Methodology}

When reviewing the literature in the area of the consequences ESL holds for an individual who has left school early, we first conducted a literature search of the scientific EBSCOhost online research databases (Academic Search Complete, ERIC, PsycARTICLES, PsycBOOKS, PsycINFO, and SocINDEX with Full Text databases). The main key words initially used were: ESL and social consequences and consequences of ESL. This yielded a limited set of results. By searching for related results online we noticed the consequences of ESL are often described together with the antecedents of ESL and the costs of ESL on the national and European levels. In this way, we extended our online research databases search with key words referring to the antecedents and consequences of ESL, the costs of school failure and calculating the costs of ESL. We also examined references cited in the reviewed articles and paid special attention to the reports of different European Commission expert group reports, i.e. the European Expert Network on Economics of Education (EENEE). Texts taken into account had to address the private and social consequences of ESL along with direct and indirect interactions between different areas of consequences. 


\section{Private and social far-reaching consequences of ESL}

In this section, we further describe the private and social consequences of ESL as defined in the introduction. Thus, the private and social far-reaching consequences of ESL we present in this section are: higher incidence and duration of unemployment, lower initial and lifetime earnings, inferior health status and public health assistance access, less risk aversion and increased criminality, reduced lifelong-learning participation, lower quality of social capital (lower positive spill-over effects of co-workers) and lower lifetime satisfaction (negative intergenerational effects).

\section{Higher incidence and duration of unemployment}

Various sources (e.g. Garfinkel, Kelly, \& Waldfogel, 2005; Gyönös, 2011; Lamb, 1994; USA Department of Labor, 2004) state that ESLers are 72\% more likely to be unemployed than high-school graduates. ESLers are thus also likely to receive public assistance. Gyönös (2011) found that a low qualification level and the possibility of becoming unemployed increase in direct proportion. With constant changes in the skills required in the labour market, ESLers are also becoming a less employed population as the years

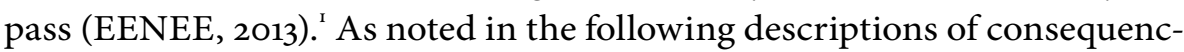
es, unemployment amongst ESLers brings an important impact to different areas of an individual's well-being.

\section{Lower initial and lifetime earnings}

An EENEE estimate (2013) puts the additional lifetime income of a student who stays at school for one extra year at more than $€ 70,000$. Further, Oreopoulos (2007) states that lifetime wealth increases by about $15 \%$ for an extra year of schooling. Therefore, parallel to the increased risk of ESLers being uneducated and unemployed, both their initial and lifetime earnings drop. It is also important to note that ESLers tend to be myopic since they do not possess the skills required for planning and managing their finances (Gyönös, 2011). This is an additional reason they usually possess low lifetime earnings in their adult life and thus a lower quality of life in general.

The prevailing understanding in modern society that ESL is a major cause of high unemployment is challenged by some authors (e.g. Ross \& Leathwood, 2013; De Witte et al., 2013; Huart, 2013) who argue that keeping students in school will not resolve the problem of (youth) unemployment. 


\section{Lower health status and public health assistance accessibility}

Early unemployment is also importantly connected to adult physical and psychological health problems. Hammarström and Janlert (2002) state that the most commonly stated health problems within the ESL population are psychological health problems (e.g. depression, anxiety), somatic health problems (e.g. headache, weight problems, gastric complaints, problems with locomotive apparatus, infections, accidental injuries, allergies), alcohol consumption, and smoking. Males are especially at risk for somatic and psychological health problems. The European Commission (2010) states, for example, that in England young men who are not in education or training are three times more likely to be depressed than those involved in any kind of educational activity. ESLers are also less likely to have health insurance and are simultaneously at greater risk for both early death and a variety of poor health outcomes (Clark \& Royer, 2010; Davidoff \& Kenney, 2005; Mazumder, 2010). Lochner (2011) states there are many ways in which education improves health. They include stress reduction, better decision-making and information gathering, a higher likelihood of having health insurance, healthier employment, better neighbourhoods and peers, and low-risk health behaviours such as avoiding smoking, drinking, eating calorie-intensive food and refraining from exercising. Education is therefore closely tied to many aspects of an individual's quality of health and as such also holds far-reaching effects for an individual's health in adulthood (European Commission, 2010).

\section{Less risk aversion and increased criminality}

Different studies (e.g. Aloise-Young, Cruickshank, \& Chavez, 2002; Crum, Ensminger, Ro, \& McCord, 1998; Fegan \& Pabon, 1999; Henry, Caspi, Moffitt, Harrington, \& Silva, 1999; Jarjoura, 1996; Voelkl, Welte, \& Wieczorek, 1999) confirm that ESLers are at greater risk of participating in all forms of delinquency (e.g. drug use and drug selling, criminal behaviour) and have more contacts with the juvenile justice system. Machin, Marie and Vucic (2011) defined three channels via which education may have an effect on crime: income effects, time availability, and patience or risk aversion. Time spent in education reduces the time available to participate in criminal activity. While at school, youngsters stay off the streets. Through education they also develop an awareness of the importance of risk aversion and understand the long-term effects of future punishment and future income losses from imprisonment (EENEE, 2013; Machin et al., 2011; Moretti, 2007; 
Moretti, Jacob, \& Lefgren, 2007). Education also increases the possibility of legitimate work, higher income and thereby lowers the risk of illegal behaviour in the future (Brunello \& De Paola, 2013; Jarjoura, 1993).

\section{Reduced lifelong-learning participation}

As mentioned, ESLers are more likely to be unemployed, draw on welfare, and have even less of a chance to become employed as time passes (EENEE, 2013). Consequently, they lose their work-related social ties and a sense of purpose and belonging to a certain working community. Studies (e.g. Brunello \& De Paola, 2013; EENEE, 2013; Moretti, 2007) show that, as such, in later life ESLers are much less likely to be active citizens and to become involved in lifelong learning. If unemployed, in adult life they are already very distant from the education system, the skills required to be involved in the educational process and also the skills needed to successfully enter the labour market (Business Council of Australia, 2003). Lifelong-learning participation is therefore importantly affected by ESL (Fergusson, SwainCampbell, \& Horwood, 2002).

\section{Lower quality of social capital (lower positive spill-over effects of co-workers)}

Several authors (e.g. Hawkins, Catalano, \& Miller, 1992; Jarjoura, 1993) confirm that educational failure leads to decreased social bonds with the school and communities, which in turn leads to a greater risk of crime and delinquent behaviours. An individual therefore finds his sense of belonging and becomes socially connected to groups that do not encourage his/ her participation in education and legitimate work. ESLers' social disconnectedness therefore increases. Sweeten, Bushway and Paternoster (2009) also found that those who drop out of school tend to be more antisocial and thus have even less of a chance to find and connect with positive influences in their social surroundings.

\section{Lower lifetime satisfaction and negative intergenerational effects}

Oreopoulos (2007) states that not only does education improve an individual's occupational prospects, wages and job satisfaction, but it also leads to more informed decision-making regarding health, marriage, parenting and retirement. Schooling also importantly affects individual non-cognitive 
skills and attitudes, such as risk aversion, patience and motivation, which influence economic choices. And these are all factors that shape an individual's satisfaction with life and also form a basis for building a satisfactory life in the future and for future generations. With ESLers dropping out of school too soon, they lose this potential and a greater risk also emerges of their future generations adopting maladaptive behavioural patterns.

\section{Relatedness of the private and social consequences of ESL}

As seen from the study results stated above relating to the long-term consequences of ESL, all of the consequences are somehow interrelated and together form an overall impact on ESLers' quality of life, including in adulthood. However, different researchers pose a question regarding the causality of those effects. Some authors (e.g. Crum et al., 1998; Hawkins et al., 1992; Henry et al., 1999; Jarjoura, 1993; Lamb, 1994; Silbereisen, Robins, \& Rutter, 1995) suggest there is a causal association between leaving school without qualifications and later outcomes, such that: a) leaving school without qualifications reduces opportunities for social participation and integration; and b) reduced opportunities for social participation are reflected in higher rates of crime and other maladaptive behaviours. This implies that lowering the number of ESLers will have a positive effect by way of reducing crime, substance use and welfare dependence. Some authors (e.g. Bridgeland, Dilulio, and Morison, 2006; Fergusson et al., 2002) oppose this point of view and describe these associations as non-causal. Their interpretation is that a wide range of adverse social, personal, educational and behavioural factors were present prior to an individual's ESL such as a disadvantaged family background, lower cognitive ability, behavioural and adjustment problems etc. Further, that those factors are the ones that are reflected in an individual's poorer social functioning and maladaptive behaviours in later life. In this context, ESL is merely a side-effect of those adverse factors and is a form of maladaptive behaviour.

However, this does not diminish education's role and impact in providing equal opportunities for all students, regardless of their background, as a tool for combatting ESL. There is also evidence from a 21-year longitudinal study (Fergusson et al., 2002) which confirms that ESL is an important point in an individual's life that later affects his/her quality of life in the sense of a greater risk for adverse outcomes including crime, substance abuse or dependence, welfare dependence and reduced participation in any 
form of education or training, i.e. behaviours that proved to be less present in a non-ESL population.

\section{Conclusion}

This article aimed to investigate different personal and social aspects of the consequences of ESL for an individual's later life. Although there is no consensus regarding the causality between ESL and various private and social consequences, we may draw the conclusion that students at risk are individuals with specific social, personal, educational and behavioural characteristics who are more at risk of experiencing different negative consequences of ESL throughout their lives. As evident from the European Commission's review reports on the consequences of ESL (2010 and 2013), lower education levels are associated with negative consequences like lower earnings and savings, lower labour market participation, worse health and lower health insurance, lower quality of encouraging social ties, higher levels of poverty and higher levels of criminal behaviour throughout an individual's life. ESL therefore holds important negative far-reaching effects for an individual's overall well-being.

Sweeten and colleagues (2009) point to an important moment when addressing the consequences of ESL. They state the effects of ESL depend on the reason for leaving school early. Students sometimes leave school because they find it boring, sometimes because they discover they are academically far behind, while others drop out for family reasons or financial demands to start work in order to survive. However, according to the authors the reason for ESL is an indicator of which developmental direction they are heading in and what will be their new identity. If ESLers form a new, stable identity attached to another conventional institution (e.g. work), this will mean an entirely different set of consequences than dropping out with no direction, which often leads to increased crime and other maladaptive behaviours. And this is the point at which prevention and intervention programmes should take action so as to avoid or at least extenuate the negative personal and social consequences of ESL that affect all areas of an individual's life. Potential solutions include greater collaboration between governments, businesses, communities, families and education and the implementation of a systematic approach to identifying and assisting young people at risk of ESL (Business Council of Australia, 2003; European Commission, 2013). 


\section{References}

Aloise-Young, P. A., Cruickshank, C., \& Chavez, E. L. (2002). Cigarette smoking and self-reported health in school dropouts: A comparison of Mexican American and non-Hispanic White adolescents. Journal of Pediatric Psychology, 27, 497-507.

Alphen, S. (2009). The educational quality of early school leavers and the cross-national variation of their income disadvantage. Educational Research and Evaluation: An International Journal on Theory and Practice, $15,543-560$.

Belfield, C. (2008). The cost of early school-leaving and school failure. Queens College: Research report.

Bridgeland, J. M., DiIulio, J. J., \& Burke Morison, K. (2006). The silent epidemic: Perspectives of high school dropouts. A report by civic enterprises in association with Peter D. Hart research associates for the Bill and Melinda Gates Foundation. Washington, DC: Civic Enterprises.

Brunello, G., \& De Paola, M. (2013). The costs of early school leaving in Europe. IZA Discussion Paper No. 7791.

Business Council of Australia (2003). The cost of dropping out: The economic impact of early school leaving. Business Council of Australia: Annual Report.

Clark, D., \& Royer, H., (2010). The effect of education on adult health and mortality: Evidence from Britain. NBER Working Papers 16013, National Bureau of Economic Research.

Crum, R. M., Ensminger, M. E., Ro, M. J., \& McCord, J. (1998). The association of educational achievement and school dropout with risk of alcoholism: A twenty-five-year prospective study of inner-city children. Journal of Studies on Alcohol, 59, 318-326.

Davidoff, A., \& Kenney, G. (2005). Uninsured Americans with chronic health conditions: Key findings from the national health interview survey. Washington, DC: Urban Institute.

De Witte, K., I. Nicaise, J. Lavrijsen, G. Van Landeghem, C. Lamote, \& Van Damme, J. (2013). The impact of institutional context, education and labour market policies on early school leaving: A comparative analysis of EU countries. European Journal of Education, 48(3), 331-345.

EENEE (European Expert Network on Economics of Education). (2013). The costs of early school leaving in Europe. EENEE Analytical Report No. 17. 
European Commission (2010). ERASMUS Early school leaving Factsheet. Retrieved from http://ec.europa.eu/education/policy/school/ early-school-leavers_en

European Commission (2013). Reducing early school leaving: Key messages and policy support. Final Report of the Thematic Working Group on Early School Leaving. Retrieved from http:/ec.europa.eu/education/policy/ strategic-framework/doc/esl-group-report_en.pdf

Fegan, J. A., \& Pabon, E. (1990). Contributions of delinquency and substance use to school dropout. Youth and Society, 21, 306-54.

Fergusson, D. M., Swain-Campbell, N. R., Horwood, L. J. (2002). Outcomes of leaving school without formal educational qualifications. New Zealand Journal of Educational Studies, 37(1), 39-55.

Garfinkel, I., Kelly, B., \& Waldfogel, J. (2005). Public assistance programs: How much could be saved with improved education? Columbia University: Paper presented at the Symposium on the Social Costs of Inadequate Education.

Gyönös, E. (2011). Early school leaving: Reasons and consequences. Theoretical and Applied Economics, 18, 43-52.

Hawkins, J. D., Catalano, R. F., \& Miller, J. Y. (1992). Risk and protective factors for alcohol and other drug problems in adolescence and early adulthood: Implications for substance abuse prevention. Psychological Bulletin, 112, 64-105.

Hammarström, A., \& Janlert, U. (2002). Early unemployment can contribute to adult health problems: Results from a longitudinal study of school leavers. Journal of Epidemiol Community Health, 56, 624-630.

Henry, B., Caspi, A., Moffitt, T. E., Harrington, H., \& Silva, P. A. (1999). Staying in school protects boys with poor self-regulation in childhood from later crime: A longitudinal study. International Journal of Behavioral Development, 23, 1049-1073.

Huart, J. (2013). La lutte contre le décrochage scolaire. Administration \& Éducation, 137, 17-22.

Jarjoura, G. R. (1993). Does dropping out of school enhance delinquency involvement? Results from a large-scale national probability sample. Criminology, 31, 149-172.

Jarjoura, G. R. (1996). The conditional effect of social class on the dropout-delinquency relationship. Journal of Research in Crime and Delinquency, 33, $232-55$. 
Lamb, S. (1994). Dropping out of school in Australia: Recent trends in participation and outcomes. Youth and Society, 26, 194-222.

Lochner, L. (2011). Non-production benefits of education: Crime, health, and good citizenship. National Bureau of Economic Research (NBER): Working Paper No. 16722.

Lochner, L., \& Moretti, E. (2004). The effect of education on crime: Evidence from prison inmates, arrests, and self-reports. American Economic Review, 94(1), 155-189.

Machin, S., Marie, O., \& Vujić, S. (2011). The crime reducing effect of education. Economic Journal, 121, 463-484.

Mazumder, B. (2008). Does education improve health: A re-examination of the evidence from compulsory schooling laws. Economic Perspectives, 33, $1-12$.

Moretti, E. (2007). Crime and the cost of criminal justice. In C. Belfield \& H. Levin (Eds.), The price we pay (pp. 142-159). Washington: Brookings Institution.

Moretti, E., Jacob, B., \& Lefgren, L. (2007). The dynamics of criminal behavior. Journal of Human Resources, 42(3), 2007.

Muenning, P. (2007). Consequences in health status and costs. In C. Belfield \& H. Levin (Eds.), The price we pay (pp. 125-141). Washington: Brookings Institution.

Oreopoulos, P. (2007). Do dropouts drop out too soon? Wealth, health and happiness from compulsory schooling. Journal of Public Economics, 91, 2213-2229.

Psacharopoulos, G. (2007). The costs of school failure: A feasibility study. European Expert Network on Economics of Education.

Ross, A., \& Leathwood, C. (2013). Problematising early school leaving. European Journal of Education, 48(3), 405-418.

Silbereisen, R., K., Robins, L., \& Rutter, M. (1995). Secular trends in substance use:

Concepts and data on the impact of social change on alcohol and drug abuse. In M. Rutter, \& D. J. Smith (Eds.), Psychosocial disorders in young people: Time trends and their causes (pp. 490-543). Chichester, England: John Wiley \& Sons Ltd.

Sweeten, G., Bushway, S. D., \& Paternoster, R. (2009). Does dropping out of school mean dropping into delinquency? Criminology, 47, 47-91. 
USA Department of Labor (2004). So you are thinking about dropping out of school? Washington, DC: Office of the Secretary, USA Department of Labor: Project report.

Voelkl, K. E., Welte, J., \& Wieczorek, W. F. (1999). Schooling and delinquency among white and African American adolescents. Urban Education, 34, 69-88. 



\section{Index}

A

academic achievement $68,69,138$, 139, 141, 142, 146, 147, 152, 153, 154, $161,163,168,176,178,198,209,234$, $237,240,241,243,244,246,248$, 249, 251, 253, 255, 257, 258, 259, 260, $261,265,268,269,270,274,275$, 276, 277, 279, 281, 282, 291, 309, $324,325,327,339,348$

academic self-concept 297 aggression 60, 79, 238, 240, 243, 255, $256,257,258,264,265,267$ andragogy 23 anxiety 139, 142, 238, 242, 255, 256, 257, 258, 260, 261, 262, 263, 264, $265,266,267,324,327,330,376$ autonomy $69,180,204,207,208$, 209, 211, 212, 213, 214, 215, 219, 225, $228,271,274,276,278,279,343$

B

benchmark 24, 31, 32, 37, 38, 39, 42, 44
C

career aspirations 303, 304, 305, 306, 309, 310, 311, 312, 314, 315, 320 career guidance $23,53,71,72,74,75$, $78,82,88,95,96,98,105,107,111$, 275, 303, 304, 305, 306, 307, 308, $309,312,313,314,315,318,319,320$, 368

career management skills 13, 303, 304, 305, 306, 307, 320

civic competence $237,239,245$ community-based education 326 community learning 324, 325, 328 competence $76,126,139,144,151,169$, 180, 195, 204, 207, 211, 215, 218, 226, 233, 237, 238, 239, 240, 242, 243 , 244, 245, 246, 247, 248, 249, 250, 251, 252, 253, 259, 260, 267, 274, 279, $280,281,282,283,284,308,312$, 320

critical pedagogy $338,339,341,350$, 351 
critical thinking $337,338,339,341$, $342,343,345,346,347,348,351$ cross-sectoral cooperation 314 cultural capital $93,145,147,329,331$

$\mathrm{D}$

depression 238, 242, 243, 247, 248, $250,252,255,256,257,258,259,260$, $261,262,263,264,267,324,327$, 330,376

detection $56,78,82,188$

dyslexia 290, 291

E

early tracking $74,82,111,171,172,175$, $177,178,182$

ECEC 13, 53, 54, 56, 74, 90, 106, 109, $171,172,174,175,178,179,181,182$, 196

economic consequences $355,356,358$, $360,361,365$

educational outcomes 199, 234, 318 education and career guidance 53 , $71,72,74,75,82,88,96,98,105$ education reform 218 education system $38,52,53,54,56$, $57,70,71,73,74,75,76,78,81,82$, $88,89,90,93,95,104,105,109,110$, $111,135,137,148,156,171,172,174$, $175,176,177,181,182,183,195,222$, $287,294,313,323,327,377$

emotional competencies 14, 176, 288 emotional development 204

engagement $12,127,136,138,139,142$, $143,149,151,152,154,162,203,204$, 206, 207, 209, 210, 211, 213, 215, 216, $217,219,220,222,231,234,235,242$, $245,246,251,253,255,260,263$, $264,267,269,270,271,272,276$,
$277,279,280,282,283,284,293$,

$297,298,300,310,311,351,362,369$

ESL officer 52, 58, 60, 61

ESL prevention 42, 97, 163, 256, 269, $270,272,279,288,295,323,331,342$

ESL statistics $52,54,72,76,88,90$, 104, 107

ET 2020 13, 19, 22, 32, 35, 36, 37, 41, $42,43,46,48,49,83,98,128,150$, 367

externalising behaviour 238, 240, $243,244,247$

externalization difficulties 256 extracurricular activities 163, 209, $237,238,246,247,251,312,328$

F

family background 136, 241, 259, 269, 270, 292, 378

France $7,11,14,23,25,31,33,34,36$, $39,40,41,43,44,45,51,52,53,54$, $55,56,62,63,69,78,118,122,126$, $128,175,199,200,233,235,236,291$, 299

G

good governance $31,32,33,44$ grade retention $52,73,74,82,88,89$, $159,171,172,174,175,176,178,181$, $183,185,196,199$

I

individual factors $135,136,138$ internalising behaviour 238, 240, $242,244,247$

internalization difficulties 256 international comparative assessment 24, 222 
L

learner-centred approach 205

learning difficulties 23, 68, 257, 261, $263,265,287,288,289,290,292$, 293, 294, 295, 296, 297, 298, 299, 300,301

learning disabilities 266, 298, 299 low achievement 139, 140, 147, 187, $188,195,196,199,255,263,292,347$

Luxembourg $7,11,14,23,33,34,36$, $39,40,44,47,48,63,65,71,72,73$, $74,75,76,77,78,80,81,82,83,84$, $85,86,99,113,115,118,122,126,150$, $151,168,175,184,185,252,316,317$, 368

\section{M}

mainstream education $56,67,79,285$ media literacy $23,337,338,339,340$, $341,342,343,345,346,347,348$, $349,350,351$

motivation $21,79,97,99,136,138$, 139, 140, 143, 145, 148, 168, 180, 194, 195, 198, 204, 207, 212, 213, 214, 215, $219,220,228,231,245,249,252,274$, $275,279,284,292,293,294,297$, 299, 309, 310, 311, 319, 323, 324, 327, $328,330,334,338,343,347,349,378$ motivation for school work 292 multi-professional collaboration 52 , $58,61,62,73$

multi-professional ESL-prevention groups 51,52

multi-professional partnership 104 multi-professional teams 20, 22, 25, $72,81,82,88,98,122,127$
$\mathrm{N}$

non-formal education 107

0

open method of coordination 32,34 , 118,131

P

parent-child/adolescent relationship 270,278

parenting style $12,145,146,206,207$, 209, 213, 269, 270, 271, 272, 273, $274,275,276,278,280$

personality $142,151,152,153,215,216$, $218,219,253,267,282$

physical activity 23, 323, 324, 325, $326,327,328,329,330,331,332,333$, 334, 335

PISA $8,14,23,89,101,106,130,145$, $147,153,160,161,165,168,169,177$, $178,186,187,188,189,190,191,192$, 193, 194, 195, 196, 197, 198, 199, 200, 220, 224, 226, 228, 229, 230, 231, $232,234,235,369$

policy experimentation $26,118,122$, $126,127,129$

policy learning $12,32,34,40,41,42$, $44,49,117,118,119,120,121,122$, $123,124,125,126,127,128,129,130$, 131

policy measures $21,40,41,52,72,363$ policy problem 22, 124, 126 positive youth development 149 private consequences 372 problem behaviour 135, 136, 139, 144, $148,177,237,238,239,240,244,247$, 298 
professional development $36,44,72$, $80,97,165,213,223,225,227,228$, $233,288,295,296,298$

protective factors $74,83,90,135,136$, $137,142,144,145,154,165,170,172$, $178,179,182,205,212,217,229,234$, $237,243,245,246,253,309,381$

\section{$\mathrm{R}$}

relatedness 378

relevance of schooling 303, 304, 305, 306, 309, 312, 314

resilience $149,152,238,243,247,248$, 266,319

S

school achievement 141, 188, 195, 196, 197, 212, 266, 270, 271, 274, 291

school climate $156,162,163,165,166$, 222, 229, 230, 231, 232, 234, 256, 258, 266

school composition $155,156,158,159$, 164, 166, 196, 197

school engagement 143, 151, 154, 204, 210, 219, 245, 267, 269, 270, 271, 276, 280,284

school factors $151,154,155,156,158$, 159, 170, 185, 186, 199

school practices $155,156,158,160$, $162,166,177$

school structure 98, 155, 156, 158, 160 second-chance education 78, 109 self-concept 139, 250, 275, 297, 298 self-determination theory 211, 335 social and emotional competence 226, 233

social background 8, 153 social behaviour 154, 161, 237, 238, 240,244 social capital 136, 145, 147, 148, 277, $283,317,371,372,375,377$ social competence $139,144,237,238$, 239, 240, 243, 244, 247, 248, 251, $252,253,260,280$

social consequences $355,356,358$, $363,365,366,371,372,374,375,378$, 379

socio-economic segregation 171,172 , $175,176,182$

Spain 7, 11, 23, 31, 33, 34, 38, 39, 40, $43,87,88,89,90,91,92,93,94,95$, 96, 97, 98, 99, 100, 101, 118, 152, 175, $193,194,195,198,199,359,366$

Switzerland 8, 11, 23, 25, 33, 103, 104, $105,106,107,108,109,110,111,112$, $113,114,118,122,126,189,190,193$, 195

system level 74, 171, 173, 180, 309, 364<smiles>C1CCC1</smiles>

teacher-student relationship 204, $210,212,213,222,224,230$ team cooperation $14,15,20$ transitions $52,53,73,74,82,88,89$, $105,108,111,171,172,180,184,258$, $295,304,307,308,311,314,320$

V

VET 14, 54, 56, 76, 78, 92, 95, 104, 109, 112, 171, 172, 174, 175, 180, 181, 182

\section{W}

whole school approach 42, 47, 299, 317 


\section{List of Authorities}

A

Adalbjarnardottir, S. 270, 271, 273, 274, 276, 278, 279, 280

Alexiadou, N. 33, 37, 39, 40, 43, 45, $117,125,127,128,131$

Alivernini, F. 198

Allenbach, M. 110, 113

B

Bandura, A. 242, 247, 248

Barnas, M. 205, 206, 207, 212, 214

Basch, C. E. 326, 332

Battin-Pearson, S. 136, 141, 149, 206, 212, 214, 218, 240, 241, 244, 248, $251,258,264,274,280$

Baumrind, D. 207, 214, 269, 270, 271, $273,274,280$

Berthet, T. 56, 63, 128, 316

Blondal, K. S. 269, 270, 274, 279, 280

Bridgeland, J. M. 143, 149, 163, 167, $175,183,378,380$

Brunello, G. 366,380
C

Caprara, G. 248

D

Deci, E. L. 211, 215, 219

DeSocio, J. 256, 257, 258, 259, 262, 263,264

Dolowitz, P. D. 119, 120, 123, 127, 128, 129

Downes, P. 22, 26, 164, 165, 166, 167, $168,183,242,245,248,256,264$, 307,317

Dubet, F. 56, 63

$\mathrm{E}$

Eccles, J. S. 89, 99, 158, 168, 178, 179, $180,184,248,271,275,278,281,282$, $284,328,335$

Enguita, M. F. 88, 90, 99, 193, 194, 198

Epstein, J. L. 333

Esch, P. 83, 249 
F

Fernández-Macías, E. 94, 100

Friedel, C. 79, 81, 86, 215

G

Gilles, J. L. 79

Green, A. 362,368

H

Hankivsky, O. 361, 368

Hardie, E 299

Hargreaves, D. 233

Hawkins, J. D. 149, 218, 240, 248, 250, 251, 258, 264, 274, 280, 377, 381

Henry, B. 142, 151, 376, 381

Hootman, J. 256, 257, 258, 259, 262, 263,264

Howlett, M. 126, 128

J

Janosz, M. 141, 142, 143, 149, 152, 157, $169,175,185,214,216,217,242,245$, $252,253,267,271,278,279,280,281$, 293, 300

Jennings, P. A. 233

Jimerson, S. 137, 152, 157, 169, 175, 176, $179,183,185,217,240,250,270,271$, 277,282

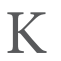

Kellner, D. 341, 342, 350

Knighton, T. 199, 234

$\mathrm{L}$

Lerner, R. M. 99, 168

M

Mahuteau, S. 199

Marks, G. N. 152, 200, 209, 218, 222, 235
Masten, A. S. 251, 266, 319

Mikk, J. 229, 235

P

Plant, P. 303, 304, 312, 318, 319, 368, 369

Psacharopoulos, G. 356, 358, 361, 365, 369,382

Q

Quiroga, C. V. 242, 252, 267

$\mathrm{R}$

Radaelli, M. C. 33, 39, 40, 43, 45, 49, $117,118,119,121,122,123,124,125$, $127,129,131$

Rogers, L. 142, 153, 166, 170, 180, 186, 214, 293, 301, 347, 351

Rose, R. 123, 127, 131

Rumberger, R. W. 137, 142, 153, 163 , 170, 186, 209, 212, 217, 219, 240, 252, 269, 270, 271, 274, 276, 278, 284

Ryan, R. M. 204, 207, 209, 211, 214, 215, 216, 218, 219, 242, 252, 279, 284, $318,330,335$

S

Schleicher, A. 228, 231, 236

Shephard, R. J. 326, 333, 334

Smink, J. 301, 309, 319, 327, 328, 334

Strong, W. B. 334

Sultana, R. G. 320

$\mathrm{T}$

Thibert, R. 53, 54, 56, 59, 65, 109, 110, $111,115,138,154$

Thoman, E. 352

Tièche Christinat, C. 79, 84 
Traag, T. $142,143,144,145,154,170$, 186, 253

Turner, M. Y. 208, 218, 219

V

Vallejo, C. 101

Vidmar, M. 8, 142, 154, 171, 237, 244, 253, 318

Vieluf, S. 225, 236

Vitaro, F. 144, 154, 245, 253

W

Walker, J. M. 203, 204, 205, 206, 207, 214, 220, 277, 282

Watts, A. G. 321 
Early School Leaving: Contemporary European Perspectives

Scientific monograph

Editors: Urška Štremfel and Maša Vidmar

Series: Digitalna knjižnica/Digital Library

Editorial Board: Igor Ž. Žagar (Educational Research Institute \& University of Primorska), Jonatan Vinkler (University of Primorska), Janja Žmavc (Educational Research Institute), Alenka Gril (Educational Research Institute)

Subseries: Dissertationes (znanstvene monografije/Scientific Monographs), 32

Editor in chief: Igor Ž. Žagar

Reviewers: Katja Košir, Marta Licardo

Proofreading: Murray Bales

Graphic Design, Typesetting and Digitalization: Jonatan Vinkler

Publisher: Pedagoški inštitut/Educational Research Institute

For the Publisher: Igor Ž. Žagar

Ljubljana 2018

ISBN 978-961-270-267-0 (pdf)

http://www.pei.si/ISBN/978-961-270-267-o.pdf

ISBN 978-961-270-268-7 (html)

http://www.pei.si/ISBN/978-961-270-268-7/index.pdf

DOI: https://www.doi.org/10.32320/978-961-270-267-0

(C) 2018 Pedagoški inštitut/Educational Research Institute

The publication was produced as part of the project »TITA (Team cooperation to fight early school leaving: Training, Innovative Tools and Actions)«. The project was co-financed by the European Commission. This publication has been produced with the assistance of the European Union. The contents of this publication are the sole responsibility of the authors and can in no way be taken to reflect the views of the European Commission.

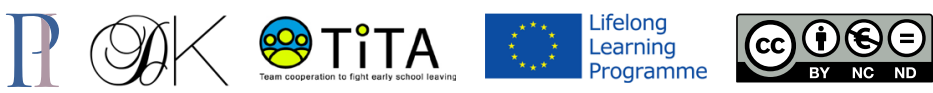

Kataložni zapis o publikaciji (CIP) pripravili v Narodni in univerzitetni knjižnici v Ljubljani COBISS.SI-ID=293028096 



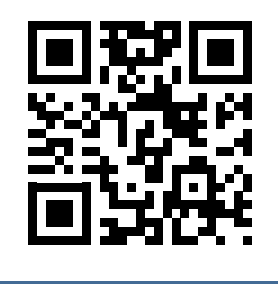

